\title{
MUDANÇAS NO SETOR SUPERMERCADISTA E A FORMAÇÃO DE ASSOCIAÇÕES DE PEQUENOS SUPERMERCADOS
}

\author{
ARIEL WILDER
}

Dissertação apresentada à Escola Superior de Agricultura "Luiz de Queiroz", Universidade de São Paulo, para obtenção do título de Mestre em Ciências, Área de Concentração: Economia Aplicada.

P I R A C I C A B A

Estado de São Paulo - Brasil

Outubro de 2003 


\section{MUDANÇAS NO SETOR SUPERMERCADISTA E A FORMAÇÃO DE ASSOCIAÇÕES DE PEQUENOS SUPERMERCADOS}

\section{ARIEL WILDER}

Engenheiro Agrônomo

Orientador: Prof. Dr. PEDRO VALENTIM MARQUES

Dissertação apresentada à Escola Superior de
Agricultura "Luiz de Queiroz", Universidade de São
Paulo, para obtenção do título de Mestre em
Ciências, Área de Concentração: Economia
Aplicada.

P I R A C I C A B A

Estado de São Paulo - Brasil

Outubro de 2003 
Dados Internacionais de Catalogação na Publicação (CIP) DIVISÃO DE BIBLIOTECA E DOCUMENTAÇÃO - ESALQ/ USP

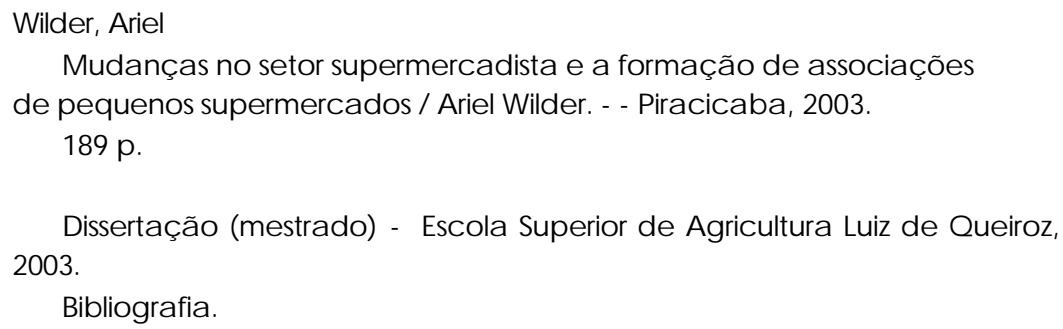

1. Associação comercial 2. Organização industrial- Teoria 3. Supermercados I. Título

CDD 658.878 
Aos meus pais, Gabriela e David, e à minha família que com seu carinho e compreensão me apoiaram em mais esta fase da vida.

À Cláudia que compartilhou comigo as alegrias e desafios da realização deste trabalho 


\section{AGRADECIMENTOS}

Ao Professor Dr. Pedro Valentim Marques sou especialmente grato por se disponibilizar prontamente a ser meu orientador e pelos conselhos e dedicação para a realização deste trabalho.

À Professora Dra. Márcia Azanha Ferraz Dias Moraes, do Departamento de Economia, Administração e Sociologia da Escola Superior de Agricultura "Luiz de Queiroz", pela paciência e prontidão em contribuir para a realização deste trabalho.

Aos Professores Dra. Silvia Helena G. de Miranda e ao Dr. Alexandre L. Mendonça de Barros do Departamento de Economia, Administração e Sociologia da Escola Superior de Agricultura "Luiz de Queiroz", pelas importantes contribuições para este trabalho.

À Professora Elizabeth M.M.Q. Farina, do Departamento de Economia da Faculdade de Economia, Administração e Contabilidade, pelas valiosas sugestões para o embasamento teórico deste estudo.

Ao Sr. Ismael Caldas, presidente da Rede Econômica, ao Sr. Pedro Luiz Defávare, presidente da Rede Economize, e ao Sr. Eder de Campos Camargo, pela disposição em me receber, pois sem suas colaborações este trabalho não seria possível. E a todos os associados das redes estudadas que se prontificaram a responder o questionário.

À todos os funcionários do Departamento de Economia, Administração e Sociologia da Escola Superior de Agricultura "Luiz de Queiroz", em especial à Maielli, 
à Helena, à Cristiane, à Márcia, ao Pedro, à Ligiana, ao Álvaro que sempre me atenderam com simpatia, profissionalismo e prontidão.

E a todos os colegas e amigos da turma de mestrado e do departamento que tornam esta fase mais agradável e proveitosa. E, em especial ao Umberto A. Sesso Filho que também contribuiu para a realização deste trabalho. 


\section{SUMÁRIO}

Página

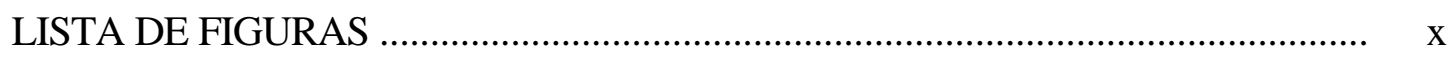

LISTA DE QUADROS............................................................................ xii

LISTA DE TABELAS …...................................................................... xiii

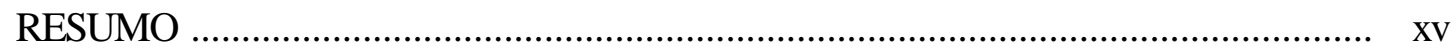

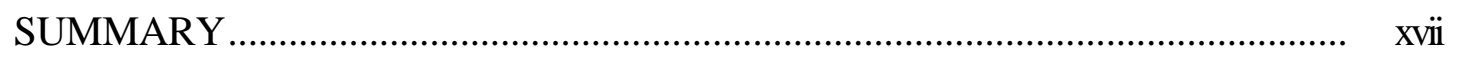

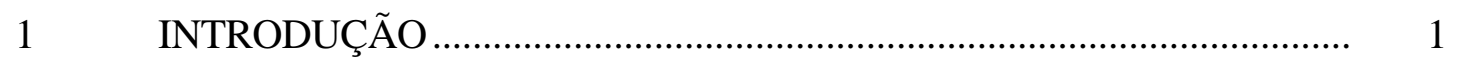

1.1 Definição de supermercados e suas categorias ......................................... 2

1.2 O setor de auto-serviço no Brasil ............................................................. 3

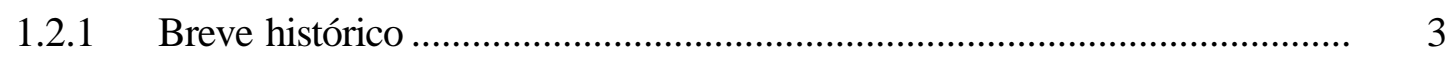

1.2.2 Relevância econômica......................................................................... 7

1.3 Associações de supermercados independentes .......................................... 9

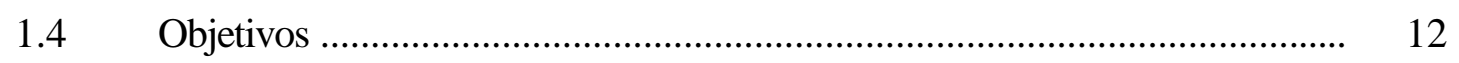

1.4.1 Objetivo geral............................................................................ 12

1.4.2 Objetivos específicos .................................................................. 12

2 REFERENCIAL TEÓRICO ........................................................... 13

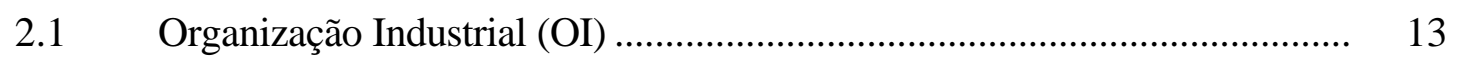

2.2 Economia dos Custos de Transação (ECT) ............................................... 26 
2.2.1 Pressupostos comportamentais ......................................................... 30

2.2.2 Dimensões das transações ..................................................................... 31

2.2.2.1 Especificidade dos ativos ................................................................. 31

2.2.2.2 Freqüência ...................................................................................... 35

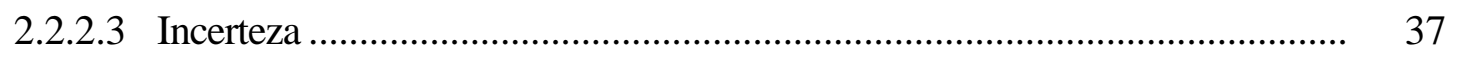

$2.3 \quad$ Relações verticais............................................................................ 38

2.4 Ação coletiva ......................................................................................... 44

2.4.1 Conceitos básicos da Lógica da Ação Coletiva e incentivos à formação de organizações ..................................................................................... 45

2.4.2 A lógica olsoniana .................................................................... 50

2.4.2.1 Tipos de organização .......................................................................... 50

2.4.2.2 Considerações sobre a lógica olsoniana..................................................... 57

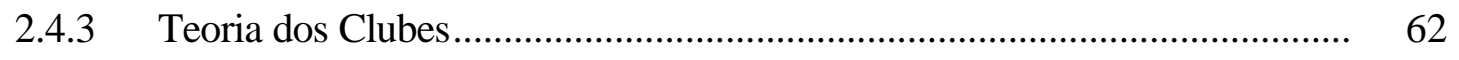

2.5 Organização Industrial, Economia dos Custos de Transação e a Ação Coletiva ......................................................................................... 65

3 REVISÃO DE LITERATURA .......................................................... 67

3.1 Ambiente competitivo do setor de auto-serviço ....................................... 67

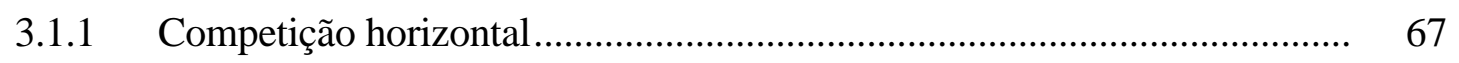

3.1.1.1 Índices de concentração no setor ......................................................... 74

3.1.2 Competição vertical .............................................................................. 75

3.1.3 Competição geográfica ...................................................................... 80

3.1.4 Condições de entrada ........................................................................ 82

3.1.5 Economias de escala ................................................................... 85

3.1.6 Índices de desempenho .................................................................. 87 
3.1.7 Padrões de concorrência...................................................................... 88

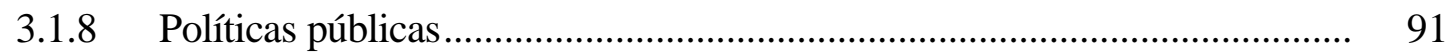

3.2 O setor supermercadista brasileiro após o Plano Real ................................ 92

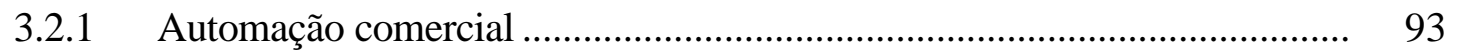

3.2.2 Alterações nos hábitos dos consumidores................................................. 96

3.2.3 Processo de concentração..................................................................... 99

3.3 Organizações de compras...................................................................... 100

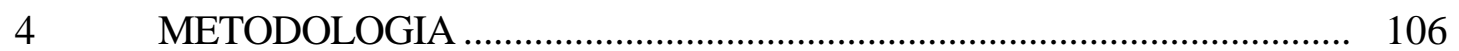

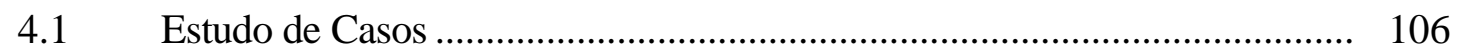

4.2 Desenvolvimento da pesquisa ................................................................ 108

$5 \quad$ RESULTADOS E DISCUSS ÃO …........................................................ 112

5.1 Relação entre estrutura, conduta e desempenho para o setor

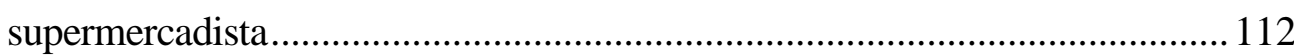

5.1.1 Condições básicas ......................................................................... 113

5.1.2 Estrutura de mercado ...................................................................... 114

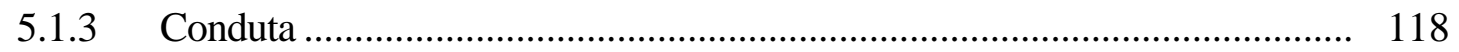

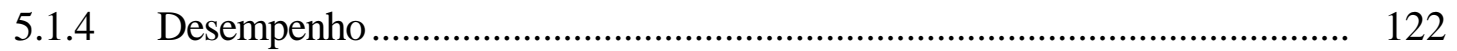

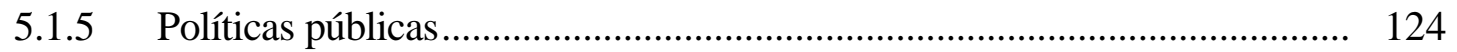

5.1.6 Relação esquemática entre estrutura, conduta e desempenho ...................... 125

5.1.7 Relação entre as mudanças no setor supermercadista e formação das associações.............................................................................................. 127

5.2 Apresentação das redes estudadas .......................................................... 130

5.2.1 Rede Econômica ........................................................................ 131

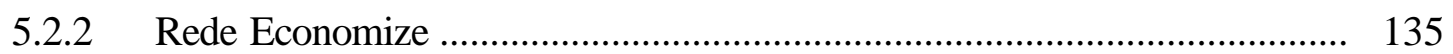


5.2.3 Resultados obtidos com as associações ................................................. 137

5.3 Economia dos Custos de Transação e as redes ........................................... 146

5.4 As redes como ações coletivas.......................................................... 148

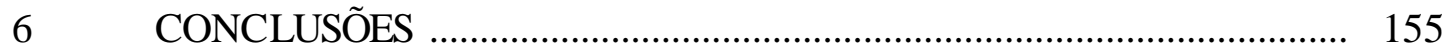

REFERÊNCIAS BIBLIOGRÁFICAS ............................................................ 162

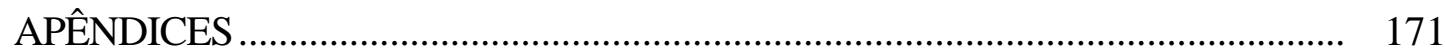




\section{LISTA DE FIGURAS}

Página

1 Relações entre estrutura, conduta e desempenho .............................................. 15

2 Relações entre arranjo e Ambiente Institucional.................................................. 27

3 Custo de estrutura de governança e nível de especificidade dos ativos .............. 34

4 Estrutura de Governança resultante da relação entre incerteza e especificidade 38

5 Preços do varejo em relação ao grau de substitutibilidade e número de

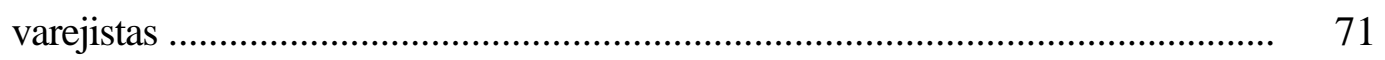

6 Níveis de Bem-estar social em relação ao grau de substitutibilidade e número

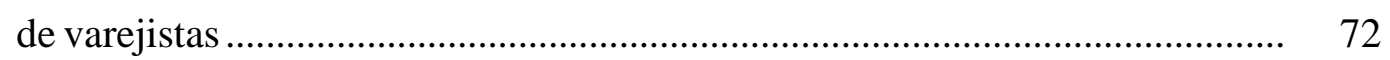

7 Participação de Mercado das cinco maiores empresas varejistas (em \%)........... 74

8 Automação comercial no setor supermercadista brasileiro ................................ 94

9 Modelo de Termos Anglo-americano para cooperações horizontais ................. 103

10 Comparação entre volume de transações necessárias com e sem consórcio....... 105

11 Participação percentual das quatro e oito maiores empresas em faturamento bruto algumas variáveis do setor ................................................................. 116

12 Variação de índices selecionados entre os anos de 1997 e 2001 ....................... 122

13 Índices de eficiência selecionados entre os anos 1994 e 2001 para o setor de auto-serviço 
14 Índices de eficiências selecionados entre os anos de 1997 e 2001 para o setor de auto-serviço.

15 Resumo da estrutura-conduta -desempenho para o setor supermercadista 126

16 Transformações do setor supermercadista na década de 90.

17 Principais razões citadas que levaram os supermercados a associar-se à rede....

18 Participação dos itens fornecidos a partir de negociações conjuntas da associação no total dos itens vendidos pela loja

19 Redução nos custos de aquisição dos produtos comprados pela associação, distribuição percentual por faixa de decréscimo.

20 Redução no número de funcionários após a entrada na associação, distribuição percentual por faixa de decréscimo.

21 Redução nos estoques, distribuição percentual por faixa de decréscimo.

22 Redução nas faltas de produtos nas prateleiras, distribuição percentual por faixa de decréscimo.

23 Redução percentual nos preços, distribuição percentual por faixa de decréscimo

24 Melhora na qualidade dos produtos

25 Melhora no atendimento ao cliente

26 Aumento médio percentual no faturamento da loja com a entrada na associação 


\section{LISTA DE QUADROS}

Página

1 Potencial de crescimento versus competitividade dos negócios varejistas em diversos países do mundo ........................................................................ 6

2 Estruturas básicas de mercado ...................................................................... 20

3 Comparação entre estudos que relacionam índices de concentração e de preços. ... 73 


\section{LISTA DE TABELAS}

Página

1 Classificação de lojas do setor supermercadista................................................ 3

2 As sete maiores empresas de supermercados e a origem do capital nos anos de 1991 e 2001, em ordem de faturamento.

3 Participação dos setores selecionados da economia no PIB brasileiro................ 8

4 Número de empregos diretos de setores selecionados da economia .................. 9

5 Dados sobre associações / centrais de compras em 2000 ................................. 10

6 Ranking das dez maiores centrais de compras .................................................. 10

$7 \quad$ Perfil das associações e centrais de compra ........................................................ 11

8 Área de influência de supermercados ............................................................ 81

9 Crescimento percentual no número de empresas no setor de varejo de alimentosno Brasil. ........................................................................................ 84

10 Média percentual do lucro líquido sobre faturamento bruto............................. 87

11 Atributos mais citados para a escolha do local de compras .............................. 89

12 Margens de comercialização (markup) em supermercados antes e após a implementação do Plano Real (1994)................................................................... 93

13 Elasticidade-renda da despesa de alimentos no Brasil em 1995/96................... 97 
14 Modificações do comportamento do consumidor após a estabilização econômica. 98

15 Participação percentual dos formatos de loja entre 1999 e 2001 no Brasil. ........ 99

16 Concentração do setor supermercadista brasileiro em 2001 ............................. 114

17 Indicadores de concentração no setor supermercadista no Brasil ....................... 115

18 Número de fusões e aquisições no setor supermercadista ................................. 119

19 Dados selecionados sobre as cidades onde atua a Rede Economize ................. 135 


\section{MUDANÇAS NO SETOR SUPERMERCADISTA E A FORMAÇÃO DE ASSOCIAÇÕES DE PEQUENOS SUPERMERCADOS}

Autor: ARIEL WILDER

Orientador: Prof. Dr. PEDRO VALENTIM MARQUES

\section{RESUMO}

Com o objetivo de analisar a formação de associações de compras por pequenos supermercados, buscou-se, primeiramente, estudar a organização do setor supermercadista em que as redes se inserem, utilizando o instrumental da teoria da Organização Industrial (OI). Desta parte, pode-se destacar que o setor: (i) possui baixas barreiras à entrada, (ii) a entrada pode ocorrer de forma "tempestiva", ou seja, em menos de dois anos, (iii) existem consideráveis economias de escala, (iv) o principal fator na escolha do consumidor é o preço médio de uma cesta de produtos e (v) possui um número grande de empresas atuando, porém a renda bruta concentra-se entre grandes empresas $\left(\mathrm{C}_{8}=43,7 \%\right)$. O setor, durante a década de 90 , sofreu um processo de internacionalização do capital entre as grandes firmas e, principalmente na segunda metade da década, investiu em tecnologia, melhoria da eficiência operacional e novos mercado, deixando de atuar regionalmente para uma ação em nível nacional. Essas características, juntamente com as mudanças no setor, refletiram diretamente no 
desempenho e conduta das pequenas e médias firmas do setor que se encontravam sob a área de influência das grandes redes e buscaram formas de adaptarem-se a nova realidade. Entre outras estratégias, destaca-se a formação de associações de compras. Estas associações foram estudadas sob duas óticas, a Economia dos Custos de Transação e a Ação Coletiva, visando responder "como" e "porquê" a formação das associações de redes independentes é uma estratégia para melhorar a competitividade das redes independentes. A primeira ótica busca captar as vantagens econômicas com essa organização e a segunda, os objetivos e as adversidades intrínsecas dessas organizações. Para essa análise foram escolhidas duas associações, uma com sede em Piracicaba e outra, em Limeira. Entre os benefícios observados, destacam-se algumas vantagens das grandes redes, como aumento do poder de barganha e redução nos custos de negociação e de propaganda, além de possibilitar a melhora da administração das lojas pelas trocas de experiências que ocorrem durante as reuniões nas associações, como apontado por uma das associações. As adversidades compreendem principalmente as discordâncias dentro do grupo e problemas tributários que inviabilizaram as compras conjuntas nas associações estudadas. 


\section{CHANGES AT GROCERY RETAILING SECTOR AND THE ESTABLISHMENT OF PURCHASE COOPERATIVE OF SMALL SUPERMARKET}

Author: ARIEL WILDER

Adviser: Prof. Dr. PEDRO VALENTIM MARQUES

\section{SUMMARY}

The main purpose of this work is to examine the establishment of purchase cooperative of small supermarkets. Therefore, first, the organization of the supermarket sector was studied, using the tools of the Industrial Organization (IO) theory. On this hand, it is possible to emphasize that the sector: (i) shows low entry barriers, (ii) the entry can spread over short period of time, less than two years, (iii) there are considerable scale economies, (iv) the main feature of choice by the client is the mean basket's price of products, and (v) there are a great number of active enterprises but the gross income concentrates in the great enterprises $\left(\mathrm{C}_{8}=43.7 \%\right)$. In the nineties, the biggest firms of the sector went through a process of internationalization of capital and, especially in the second half of the decade, investment in technology, improvement of operational efficiency and search of new markets, abandoning the regional level of action in favor of the national level. These characteristics, together with changes at grocery retailing, 
reflected directly in the outcome and behavior of the small and medium sized firms, which were under the area of influence of the great chains. Hence, they searched for ways to adapt to the new reality. Among different strategies, the establishment of purchase association is outstanding. Then, such associations were studied under two points of view, Economy of Transaction Costs and Collective Action, in an effort to answering "how" and "why" the constitution of associations of independent chains is a strategy to improve efficiency of independent chains. The first approach aims at to capture the economic advantages under such organization and the second the aims and adversities intrinsic to such organizations. For this analysis two associations were chosen, one located in Piracicaba and the other in Limeira. Among the benefits observed, there is increase in bargaining power and decrease of negotiation and propaganda costs, besides allowed improvement in the administration through the exchange of experiences during the meetings of the associations, as one of them pointed out. The adversities, on the other hand, comprise mainly the disagreements within the group and tributary problems which disadvantages the common purchases of the studied associations 


\section{INTRODUÇÃO}

O setor de auto-serviço apresenta grandes mudanças desde a implantação do plano Real. Entre as alterações, destacam-se: o processo de concentração (principalmente através de aquisições), a modernização (com adoção de novas tecnologias e processos administrativos), a expansão (com grandes investimentos em novos estabelecimentos) e a internacionalização do capital.

O número de estabelecimentos aumentou cerca de $85 \%$ nos últimos oito anos, incrementando a rivalidade. A ampliação, em termos absolutos, deu-se principalmente entre os pequenos e médios lojistas. Porém, entre as dez maiores redes do setor, o número de lojas praticamente dobrou, evidenciando o processo de concentração. Neste contexto, a busca da melhoria na eficiência é fundamental para manter-se no mercado.

As mudanças do setor repercutiram diretamente sobre os pequenos e médios supermercados. Buscando manter-se no mercado, alguns se juntaram em associações, realizando negociações e propaganda conjunta, entre outras ações, para se tornarem mais competitivos. Portanto, a hipótese central do trabalho é que a formação de associações de redes independentes pode consistir uma estratégia de pequenos supermercados para se tornarem competitivos no mercado varejista.

Visando compreender o ambiente em que se inserem as redes independentes, primeiramente, descreve-se de forma resumida a história do setor e sua importância econômica. O objetivo do estudo é proposto, ainda, no capítulo 1. Em seguida, é apresentado o referencial teórico que embasa o trabalho. No capítulo 3 , o setor supermercadista e a formação das associações são analisados. A metodologia é discutida no capítulo 4 e os resultados e discussão são apresentados no capítulo 5. 


\subsection{Definição de supermercados e suas categorias}

Rojo (1998) classifica as lojas que comercializam alimentos em tradicionais e auto-serviço. As lojas de auto-serviço são caracterizadas por comercializarem alimentos, exporem a maioria dos produtos de maneira acessível permitindo aos fregueses se autoservirem, disponibilizarem aos clientes carrinhos e cestas e, principalmente, por possuírem o check-out, isto é, um balcão com uma caixa registradora, ou qualquer outro equipamento, que permita a soma e conferência das compras. As lojas tradicionais são aquelas nas quais a presença de um vendedor é necessária (Rojo, 1998).

A grande diversidade de características, principalmente em relação ao tamanho das lojas e aos produtos vendidos, dificulta a definição do setor supermercadista. Silveira e Lepsch (1997, p.6) definem o supermercado como "um varejo generalista, que revende ao consumidor final ampla variedade de produtos, dispostos de forma departamental, no sistema de auto-serviço".

Conforme Rojo (1998), os hipermercados e os supermercados são diferenciados pela variedade de produtos não-alimentares oferecidos. Segundo o autor, o primeiro, além dos produtos alimentares, oferece uma ampla variedade de não-alimentos, como as linhas hard (por exemplo, eletro-eletrônicos, utensílios domésticos e cine-foto-som) e soft (como confecções, cama, mesa e banho). Porém, como o setor possui outras características além da variedade de produtos, a Associação Brasileira de Supermercados - ABRAS estabeleceu uma classificação das lojas considerando a área de vendas (compreende o espaço entre o início dos caixas até e o último produto exposto), número médio de itens disponíveis, porcentagem de vendas de produtos não alimentares, número de caixas e seções, como apresentado na Tabela 1. 
Tabela 1. Classificação de lojas do setor supermercadista.

\begin{tabular}{|c|c|c|c|c|c|}
\hline $\begin{array}{l}\text { Formato } \\
\text { de loja }\end{array}$ & $\begin{array}{c}\text { Áreade } \\
\text { vendas }\left(\mathrm{m}^{2}\right)\end{array}$ & $\begin{array}{c}\mathrm{N}^{\mathrm{o}} \\
\text { médio } \\
\text { de } \\
\text { itens }\end{array}$ & $\begin{array}{c}\text { \% de } \\
\text { vendas } \\
\text { não- } \\
\text { alimentos }\end{array}$ & $\begin{array}{l}\text { Número } \\
\text { decaixas }\end{array}$ & Seções \\
\hline $\begin{array}{c}\text { Lojade } \\
\text { Conveniência }\end{array}$ & $50-250$ & 1.000 & 3 & $1-2$ & Mercearia, friose laticínios, bazar, snacks \\
\hline $\begin{array}{l}\text { Lojade } \\
\text { sortimento } \\
\text { limitado }\end{array}$ & $200-400$ & 700 & 3 & $2-4$ & $\begin{array}{l}\text { Mercearia, hortifrúti, frios e laticínios, } \\
\text { bazar }\end{array}$ \\
\hline $\begin{array}{l}\text { Supermercado } \\
\text { compacto }\end{array}$ & $300-700$ & 4.000 & 3 & $2-6$ & $\begin{array}{l}\text { Mercearia, hortifrúti, carnes e aves, frios } \\
\text { elaticínios, bazar }\end{array}$ \\
\hline $\begin{array}{l}\text { Supermercado } \\
\text { convencional }\end{array}$ & $700-2500$ & 9.000 & 6 & $7-20$ & $\begin{array}{l}\text { Mercearia, hortifrúti, bazar, carnese } \\
\text { aves, peixaria, padaria, frios elaticínios }\end{array}$ \\
\hline Superloja & $3.000-5.000$ & 14.000 & 12 & $25-36$ & $\begin{array}{l}\text { Mercearia, hortifiúti, bazar, camese } \\
\text { aves, peixaria, padaria, frios e laticínios, } \\
\text { têxtil e eletrônicos }\end{array}$ \\
\hline Hipermercado & $7.000-16.000$ & 45.000 & 30 & $55-90$ & $\begin{array}{l}\text { Mercearia, hortifiúti, carnes e aves, } \\
\text { padaria, frios e laticínios, bazar, peixaria, } \\
\text { têxtil, eletrônicos }\end{array}$ \\
\hline Loja de depósito & $4.000-7.000$ & 7.000 & 8 & $30-50$ & $\begin{array}{l}\text { Mercearia, hortifrúti, cames e aves, têxtil, } \\
\text { frios e laticínios, bazar e eletrônicos }\end{array}$ \\
\hline Clube atacadista & $5.000-12.000$ & 5.000 & 35 & $25-35$ & $\begin{array}{l}\text { Mercearia, bazar, carnes eaves, têxtil, } \\
\text { frios e laticínios e eletrônicos }\end{array}$ \\
\hline
\end{tabular}

Fonte: Brito (1998, p.77)

As empresas do setor são classificadas, ainda, pelo número de lojas. São chamadas de redes ou cadeias as firmas que possuem seis ou mais lojas e de rede ou cadeia independentes as que contam com cinco ou menos lojas.

\subsection{O setor de auto-serviço no Brasil}

\subsubsection{Breve histórico}

O auto-serviço surgiu nos Estados Unidos na década de 30, período da Grande Depressão. Nesta época, a queda da renda, causada pelo desemprego, resultou na redução de demanda e rentabilidade das tradicionais mercearias, que vendiam pelo "balcão", ou seja, o cliente era atendido por um funcionário que buscava as mercadorias. Concomitantemente, o desenvolvimento do pré-empacotamento e enlatamento permitiu 
a apresentação das mercadorias em quantidades definidas, liberando o empregado das atividades de pesagem e acondicionamento. Assim, as dificuldades econômicas e o desenvolvimento de embalagens para alimentos deram impulso ao setor (Cyrillo, 1987).

No Brasil, o auto-serviço chegou no final da década de 40 com a utilização de um regime parcial, no qual o consumidor escolhia alguns produtos sem a ajuda do balconista. Porém, apenas em 1953 foi instalada a primeira loja que utilizava o sistema completo de auto serviço, em São José dos Campos, em São Paulo. No mesmo ano, outras duas lojas foram inauguradas na cidade de São Paulo, os Supermercados Sirva-se e o Supermercados Peg-Pag (ABRAS, 1993). Os primeiros supermercados foram instalados nas áreas centrais das cidades, mais densamente povoadas e visando atender aos consumidores de maior poder aquisitivo (Cyrillo, 1987). Segundo Lepsch (2001), os primeiros supermercados eram cópias do luxuoso modelo norte-americano da época e contavam com cerca de três mil itens distribuídos por grupos de produtos em departamentos.

O setor conseguiu se desenvolver somente após a implantação do Imposto sobre Circulação de Mercadorias (ICM) ${ }^{1}$, em substituição ao Imposto sobre Vendas e Consignações (IVC) em 1967 e a sua regulamentação em 1968. Em 1966, havia 922 supermercados, aumentando para 2.936 em 1970. As altas alíquotas cobradas pelo IVC, que incidiam apenas sobre as vendas dos produtos, estimulavam a sonegação no varejo tradicional, o que era dificultada nos supermercados, devido à estrutura administrativa na qual os funcionários registram as vendas mecanicamente, reduzindo, assim, a competitividade do supermercado. O ICM, cobrado apenas sobre o valor adicionado em cada etapa da comercialização, reduzia as diferenças de preços entre o varejo tradicional e os supermercados (Cyrillo, 1987).

O I Plano Nacional de Desenvolvimento (1972-1974) incorporou metas para a área de abastecimento, entre elas a expansão das redes de supermercados. Já em 1971, o

\footnotetext{
${ }^{1}$ Cobrado apenas sobre o valor e adicionado de cada etapa da comercialização.
} 
governo destinou uma linha especial de financiamento para o setor baseado no Programa de Modernização e Reorganização da Comercialização. Contudo, apenas grandes empresas foram beneficiadas pelo programa devido às exigências que limitavam o acesso ao crédito às empresas que possuíssem um limite mínimo de faturamento anual e pelo menos seis lojas (Cyrillo, 1987). O resultado desse programa foi o acelerado crescimento do setor e o aparecimento das grandes redes, como o Grupo Pão de Açúcar, Sendas e Bompreço, durante a década de 70.

Neste período foi instalado o primeiro hipermercado, em São José dos Campos, pela empresa Peg-Pag. Em 1975, a empresa francesa Carrefour inaugurava, na cidade de São Paulo, seu primeiro hipermercado, introduzindo uma nova forma de gerenciamento. As lojas dessa rede eram unidades autônomas, que gerenciavam seus estoques, realizavam negociações e determinavam as variedades de produtos a serem disponibilizados aos consumidores (ABRAS, 1993).

No início da década seguinte, mesmo o país passando por graves problemas econômicos, observou-se aumento desproporcional do número de lojas em relação ao crescimento das vendas. Isto acarretou, na segunda metade da década, uma aguda reestruturação do setor com conseqüente redução no número de lojas e funcionários (Silva \& Famá, 1999). Lepsch (2001) afirma que a redução no faturamento do setor neste período é resultado da dificuldade das empresas em se adaptarem às constantes mudanças sócio-econômicas, que eram resultados dos sucessivos planos econômicos do governo.

$\mathrm{Na}$ década de 90, as empresas supermercadistas norte-americanas e européias aceleraram o processo de expansão a outros países, pois se encontravam em mercados consolidados (Incandela, 1999), com baixo potencial de crescimento e forte competitividade no mercado. A Andersen Consulting (1995), citada por Neves \& Fernandes (1998), aponta o Brasil como um mercado de alto potencial de crescimento e alta competitividade do negócio (Quadro 1). Estas características resultaram na vinda de empresas estrangeiras ao mercado brasileiro no final dos anos 80 e nos anos 90, 
implicando na internacionalização do capital e no aumento da concentração do setor.

\begin{tabular}{|c|c|c|c|}
\hline & \multicolumn{2}{|c|}{ Competitividade do Negócio } \\
\hline & & Alta & Baixa \\
\hline \multirow{2}{*}{ 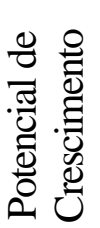 } & Alto & $\begin{array}{l}\text { México, Brasil, Argentina, Chile, } \\
\text { Coréia, Taiwan }\end{array}$ & $\begin{array}{c}\text { China, Europa do Leste, Indonésia, } \\
\text { Malásia, Tailândia, Índia }\end{array}$ \\
\hline & Baixo & $\begin{array}{l}\text { EUA, Canadá, Europa, Austrália e } \\
\text { Japão }\end{array}$ & África \\
\hline
\end{tabular}

Fonte: Adaptado de Andersen Consulting (1995), citado por Neves \& Fernandes (1998, p.18)

Utilizando-se de estratégias diferentes, as empresas internacionais entraram e ampliaram sua participação no mercado brasileiro. Carrefour, por exemplo, aumentou o número de lojas através de aquisição de outras redes e abertura de novos estabelecimentos. Em 1991, possuía 24 lojas, e em 2000, passou para 201 lojas, segundos dados da ABRAS (2002). O grupo, que concentrava sua atividade no segmento de hipermercados, começou a atuar também no segmento de supermercados sob a marca Champion ou mantendo as bandeiras originais dos supermercados adquiridos.

O grupo português Sonae entrou no país em 1989, através de joint venture com a rede Josepar (Supermercados Real S.A.) criando a empresa Cia. Real de Distribuição (CRD). Em 1990, CRD inaugurou o hipermercado Big em Porto Alegre. Em 1997, o grupo português assumiu a totalidade da CRD. No ano seguinte, adquiriu o Supermercado Cândia (sediado em São Paulo), dando origem a Sonae Distribuição Brasil S.A. (SDB), com participação de $85 \%$ das ações pela CRD e $15 \%$ pelos antigos 
donos do Supermercado Cândia. O grupo aumentou sua participação comprando outras redes no Paraná e Rio Grande do Sul.

Outros exemplos da internacionalização do capital no setor são a compra dos Supermercados Bompreço pelo grupo holandês Royal Ahold, que havia adquirido 50\% do capital em 1996 e assumiu o controle integral da rede em Junho de 2000. E do grupo francês Casino que adquiriu cerca de $22 \%$ das ações da Companhia Brasileira de Distribuição - CDB, controlada pelo grupo Pão de Açúcar S.A. Indústria e Comércio, com cerca de $47 \%$ das ações.

Observa-se pela Tabela 2, que das sete maiores empresas do setor supermercadistas em 2001, segundo os dados da ABRAS, apenas o grupo Casas Sendas Comércio e Indústrias S/A possui capital inteiramente brasileiro. Em 1991, entre as sete maiores apenas duas possuíam capital estrangeiro, Carrefour e Cia Real de Distribuição.

Tabela 2. As sete maiores empresas de supermercados e a origem do capital nos anos de 1991 e 2001, em ordem de faturamento.

\begin{tabular}{|c|c|c|c|}
\hline \multicolumn{2}{|c|}{1991} & \multicolumn{2}{|c|}{2001} \\
\hline Empresa & Origem do Capital & Empresa & Origem do Capital \\
\hline Carrefour Com e Ind S/A & Francês & Cia Brasileira de Distribuição & Brasileiro/Francês \\
\hline Paes Mendonça S/A & Brasileiro & Carrefour Com. Ind. Ltda. & Francês \\
\hline Cia Brasileira de Distribuicãa & Brasileiro & Sonae Distribuicãa Brasil S/A & Português \\
\hline Casas Sendas Com e Ind S/A & Brasileiro & Bompreço S/A & Holandês \\
\hline Bompreço S/A & Brasileiro & Casas Sendas Com e Ind S/A & Brasileiro \\
\hline Eldorado S/A & Brasileiro & Wal-Mart Brasil Ltda. & Americano \\
\hline Cia Real de Distribuição & Brasileiro/Português & Jerônimo Martins Dist. Br. Ltda. & Português \\
\hline
\end{tabular}

Fonte: Elaborado pelo autor com dados da ABRAS (2002)

\subsubsection{Relevância econômica}

O setor de auto-serviço tem destaque em particular na comercialização de bens de consumo diário e de forma geral, na economia brasileira. No início dos anos 80, segundo Lepsch (2001), 75\% desses tipos de bens eram comercializados no varejo pelo supermercado, no final daquela década representava $82,6 \%$ e, no final dos anos 90 , o 
setor de auto-serviço respondia por $86,1 \%$ do volume total de vendas de bens de consumo diário.

Esse setor possui, também, relevante participação no Produto Interno Bruto (PIB) brasileiro. Para fins de comparação, apresenta-se a participação de outros dois setores selecionados. As montadoras de carros e caminhões, por exemplo, participaram com 3,8\% do PIB brasileiro em 1997, o setor eletroeletrônico, com 4,7\%, enquanto o autoserviço, com 6\% do PIB (Tabela 3). A participação do setor supermercadista no PIB brasileiro estabilizou-se em torno dos $6 \%$ nos últimos cinco anos, tendo, em 2001, um faturamento bruto de $\mathrm{R} \$ 72,5$ bilhões.

Tabela 3. Participação dos setores selecionados da economia no PIB brasileiro.

\begin{tabular}{lccccccc}
\hline Setores & 1995 & 1996 & 1997 & 1998 & 1999 & 2000 & 2001 \\
Supermercados & $8,9 \%$ & $7,0 \%$ & $6,0 \%$ & $6,1 \%$ & $6,3 \%$ & $6,2 \%$ & $6,2 \%$ \\
Eletroeletrônicos & $7,0 \%$ & $5,4 \%$ & $4,7 \%$ & $4,8 \%$ & $4,3 \%$ & $4,7 \%$ & $4,9 \%$ \\
Automotivos & $4,4 \%$ & $3,9 \%$ & $3,8 \%$ & n.d. & n.d. & n.d. & n.d. \\
\hline
\end{tabular}

Fonte: Silva \& Famá (1999), Associação Brasileira da Indústria Elétrica e Eletrônica ABINEE (2002), ABRAS (2002)

Nota: n.d.=não disponível.

Em relação à geração de emprego, o setor atualmente possui mais de 710 mil empregos diretos. Observa-se pela Tabela 4 que o setor está contratando de forma sistemática desde 1996, com destaque para o ano de 1997 em que ampliou o número de funcionários em 4,8\%, enquanto os setores de eletroeletrônicos e automotivos, setores intensivos em capital, apresentam queda nos níveis de empregos na segunda metade da década de 90 . 
Tabela 4. Número de empregos diretos de setores selecionados da economia.

\begin{tabular}{lcccccccc}
\hline $\begin{array}{l}\text { Empregos Diretos } \\
\text { Do Setor }\end{array}$ & 1994 & 1995 & 1996 & 1997 & 1998 & 1999 & 2000 & 2001 \\
\hline Supermercados & 650.000 & 655.200 & 625.000 & 655.000 & 666.752 & 670.086 & 701.622 & 710.743 \\
Eletroeletrônicos & 180.800 & 174.100 & 163.500 & 153.000 & 142.800 & 134.200 & 139.900 & 131.100 \\
Automotivos & 107.134 & 104.614 & 101.857 & 104.941 & 83.049 & 85.100 & 85.257 & 85.257. \\
\hline
\end{tabular}

Fonte: ABINEE (2002), Associação Nacional dos Fabricantes de Veículos Automotores - ANFAVEA (2002), ABRAS(2002)

Nota: n.d. - não disponível.

\subsection{Associações de supermercados independentes}

A formação de alianças ou associações de supermercados independentes não é recente. Em meados da década de 20, nos Estados Unidos, foi fundada a Idependent Grocers Alliance, mais tarde International Grocers Alliance - IGA, com o intuito de fortalecer os supermercadistas independentes que estavam com dificuldades em competir com as grandes redes, pois estas últimas detinham maior poder de negociação junto àindústria e fornecedores.

O sistema IGA visa formar uma aliança de redes independentes, com intuito de operarem em um padrão de procedimentos de modo organizado e sistemático. Assim, esses supermercados atuam como uma rede, realizando ações coordenadas pelos Atacadistas/Distribuidores, que passa a realizar o abastecimento das lojas, que obtém vantagens semelhantes às grandes redes. Esta aliança permite aos varejistas benefícios de marketing, propaganda, mantendo-se independentes. O sistema IGA chegou ao Brasil em 1995 e atualmente possui 43 lojas franqueadas (Lokianocenko, 2001).

O Grupo Martins, maior atacadista do país, criou, a exemplo da IGA, uma franquia própria no varejo sob a bandeira Smart. Conta, atualmente, com mais de 230 lojas afiliadas. Essa franquia oferece serviços de marketing e soluções comercias, utilizando a estrutura do grupo Martins, como o Tribanco e a operadora de logística Marbo (Lokianocenko, 2001).

O Brasil possui, segundo a Associação Brasileira de Centrais de Compras - 
ABRACCOM, citado por Lokianocenko (2001), 86 centrais de compra. Uma pesquisa realizada pela ABRAS com 56 centrais de compras em 2001, apresentada pelo autor, mostra um faturamento de 2 bilhões de reais, cerca de 2,8\% da receita bruta total de setor, com participação de 1.150 empresas, totalizando 1.500 lojas, 2,2\% do total de lojas do auto-serviço (Tabela 5).

Tabela 5. Dados sobre associações / centrais de compras em 2000.

\begin{tabular}{ll}
\hline Item & Valor \\
\hline Faturamento bruto total de empresas & $\mathrm{R} \$ 2$ bilhões \\
Número de empresas participantes & 1.150 \\
Número de lojas & 1.500 \\
\hline
\end{tabular}

Fonte: ABRAS, Departamento Econômico, citado por Lokianocenko (2001)

Nota: Base de 56 centrais respondentes.

No país, a associação mais antiga, segundo Lokianocenko (2001), é a Associação Varejista do Espírito Santo - AVAES, com 23 anos, 64 associados, 79 lojas e um receita de 264 milhões de reais. Atualmente, a maior associação, apontada por uma pesquisa realizada pela ABRAS, é a Associação Redeconomia de Supermercados do Estado do Rio de Janeiro, conhecida como Redeconomia de Supermercados (Tabela 6).

Tabela 6. Ranking das dez maiores centrais de compras.

\begin{tabular}{llccccc}
\hline \multicolumn{1}{c}{ Razão Social } & \multicolumn{1}{c}{ Nome Fantasia } & UF & $\begin{array}{c}\mathrm{N}^{\circ} \text { de } \\
\text { Firmas }\end{array}$ & $\begin{array}{c}\mathrm{N}^{\circ} \text { de } \\
\text { Lojas }\end{array}$ & $\begin{array}{c}\mathrm{N}^{\circ} \text { de } \\
\text { Caixas }\end{array}$ & $\begin{array}{c}\text { Receita } \\
\text { Bruta } \\
\text { (R \$ mi) }\end{array}$ \\
\hline Assoc. Redeconomia de Sup. Estado do RJ & Redeconomia de Super & RJ & 13 & 72 & 555 & 610 \\
Assoc. Varejista do ES & Avaes & ES & 64 & 79 & 362 & 264 \\
Rede Super Ltda. & Rede Super & RS & 50 & 59 & 214 & 154,9 \\
Assoc. Emp. de Varejo e Auto-serviço Ceará & Super Rede & CE & 06 & 24 & 175 & 132 \\
Assoc. Rede Sup. de MS & Rede Econômica & MS & 38 & 52 & 250 & 120 \\
Assoc Supermais Varejo & Rede Super Mais & MG & 11 & 19 & 110 & 92,8 \\
Assoc. Central Supermercados & Central Super & RS & 38 & 38 & 120 & 69 \\
Nova Rede de Merc. do Estado do RJ & Nova Rede & RJ & 26 & 26 & 92 & 65 \\
Rede de Sup. do Sul do Brasil Mais Ltda. & Rede Mais & RS & 21 & 30 & 108 & 53,2 \\
Assoc. dos Super. Vale do Itajaí & Assuvali & SC & 15 & 20 & 85 & 42,6 \\
\hline Fonte: ABRAS, Departame
\end{tabular}

Fonte: ABRAS, Departamento Econômico, citado por Lokianocenko (2001, p.11) 
Segundo os dados apresentados na Tabela 7, observa-se que as associações são constituídas, em média, por empresas com uma loja pequena, quatro caixas e um número reduzido de funcionários. A maioria das centrais de compra tem, atualmente, entre três e cinco anos e uma característica de crescimento lento, pois agregam aos poucos novos associados (Lokianocenko, 2001).

Tabela 7. Perfil das associações e centrais de compra.

\begin{tabular}{ll}
\hline Item & Valor \\
\hline Média de lojas por firma (associado) & 1,3 \\
Média de área de vendas por loja & $400 \mathrm{~m}^{2}$ \\
Número de funcionários por loja & 23 \\
Número de check-outs por loja & 4 \\
Área de vendas por funcionário & $20 \mathrm{~m}^{2}$ \\
Faturamento por $\mathrm{m}^{2}$ & $\mathrm{R} \$ 3,1 \mathrm{mil}$ \\
\hline
\end{tabular}

Fonte: ABRAS, Departamento Econômico, citado por Lokianocenko (2001)

Nota: Base de 56 centrais respondentes.

Segundo João Carlos Dewes, presidente da Abraccom, citado por Lokianocenko (2001), as centrais de compra trazem vantagens tanto para os consumidores, quanto para os supermercadistas, fornecedores e funcionários. Os consumidores obtêm melhores preços, qualidade, promoções e atendimento. Os supermercadistas trabalham com perspectiva de melhoria permanente da loja e crescimento, com troca de experiências e conseguem aumento nas vendas e ampliação do mix de produtos. Para os fornecedores melhora o volume de vendas, a garantia de liquidez no crédito, com eliminação de intermediários, com redução nos custos de transporte e com veiculação de promoções e propagandas na TV etc. Treinamentos técnicos e direitos previdenciários e sociais e possibilidade de crescimento profissional são vantagens apontadas para os funcionários dos supermercados associados.

Os problemas mais freqüentes apontados pela Abraccom, segundo Lokianocenko (2001), são: (i) bitributação, (ii) desacordo entre associados, (iii) falta de definição clara 
do mix de produtos, (iv) atuação restrita à compra de produtos essenciais e (v) problemas administrativos.

\subsection{Objetivos}

\subsubsection{Objetivo geral}

O presente trabalho objetiva realizar uma análise exploratória, através de estudo de caso, do "porquê" da formação das associações de redes independentes e "como" elas são uma estratégia para melhorar a competitividade de pequenos supermercados e redes independentes, frente às principais mudanças da estrutura, conduta e desempenho que o setor supermercadista apresenta nos últimos anos.

\subsubsection{Objetivos específicos}

(i) estudar as características do ambiente competitivo do setor supermercadista;

(ii) verificar as vantagens e desafios de duas associações de pequenos supermercados com sede nas cidades de Limeira e Piracicaba. 


\section{REFERENCIAL TEÓRICO}

Neste capítulo, são apresentados os fundamentos teóricos nos quais se baseia a análise do setor supermercadista e das associações de supermercados. Neste trabalho, utiliza-se a teoria da Organização Industrial para compreender o ambiente em que se inserem os supermercados que participam de associações. A teoria da Economia dos Custos de Transação é empregada no estudo dos benefícios da criação de associações. Finalmente, a lógica da Ação Coletiva é aplicada para entender quais são os incentivos e limitações da formação de associações de interesse privado.

\subsection{Organização Industrial (OI)}

Segundo Scherer \& Ross (1990), o escopo da Organização Industrial (OI) é analisar como a atividade produtiva supre a demanda dos consumidores orientados pelos processos de mercado. Estuda, igualmente, como esses processos falham, como se ajustam, ou podem ser ajustados para que se aproximem de algum padrão ideal.

A teoria da Organização Industrial, baseada na teoria microeconômica, preserva a hipótese fundamental de maximização de lucro, no curto e longo prazo, que pressupõe racionalidade ilimitada. Scherer \& Ross (1990) afirmam que tanto a organização industrial quanto à teoria microeconômica preocupam-se em buscar as razões de certos fatos econômicos. Ambas visam compreender como algumas variáveis respondem a alterações de outras variáveis. Além de considerarem o tipo de organização do mercado, que une produtores e consumidores, uma variável importante.

Ainda para os autores, a organização industrial difere da microeconomia principalmente na riqueza de variáveis que a primeira procura agrupar e na preocupação 
de aplicar as explicações e os prognósticos em casos do mundo real. Carlton \& Perloff (1994) acrescentam que a organização industrial adiciona atritos do mundo real - como barreiras à entrada, custos de transação e ajustamento de preços, informação limitada e ações governamentais - ao modelo perfeitamente competitivo, considerando como as firmas competem entre si e como estão organizadas.

Conforme Scherer \& Ross (1990), muitos estudos descritivos de organização industrial tiveram como modelo os trabalhos concebidos inicialmente por Edward S. Manson, durante a década de 30. Esse modelo baseia-se em quatro pontos; (i) condições básicas (oferta e demanda), (ii) estrutura de mercado, (iii) conduta e (iv) desempenho. Segundo este modelo, o desempenho de uma indústria depende da conduta dos compradores e vendedores, que por sua vez relaciona-se com a estrutura da indústria. Já estrutura é função das condições básicas de oferta e demanda. As políticas públicas influenciam as condições básicas, a estrutura, a conduta e o desempenho, como se pode observar na Figura 1.

O desempenho de uma indústria, ainda segundo os autores, depende da conduta dos vendedores e compradores que está relacionada à política e prática de preços, formas de cooperação entre as firmas, propaganda, pesquisa e desenvolvimento de produtos etc. A conduta relaciona-se com a estrutura do mercado relevante, que inclui o número e tamanho dos compradores e vendedores, diferenciação entre os produtos concorrentes, barreiras de entrada de novas empresas etc.

Koch (1980, p.90) define estrutura de mercado como "elementos estratégicos relativamente permanentes do ambiente de uma firma que influenciam e são influenciados pela conduta e performance da firma no mercado no qual opera". A estrutura é, portanto, o ambiente em que a firma se encontra.

A estrutura do mercado é influenciada pelas condições básicas, formadas pela oferta e demanda. Pelo lado da demanda relaciona-se com a elasticidade-preço, taxa de crescimento do consumo, produtos substitutos, métodos de negociações etc. E pelo lado da oferta refere-se à tecnologia empregada, durabilidade e valor do produto, entre outros. 
Outra questão pertinente à análise é a política governamental - leis e os valores socioeconômicos da comunidade na qual o negócio se insere (Scherer \& Ross, 1990).

\section{Condições Básicas}

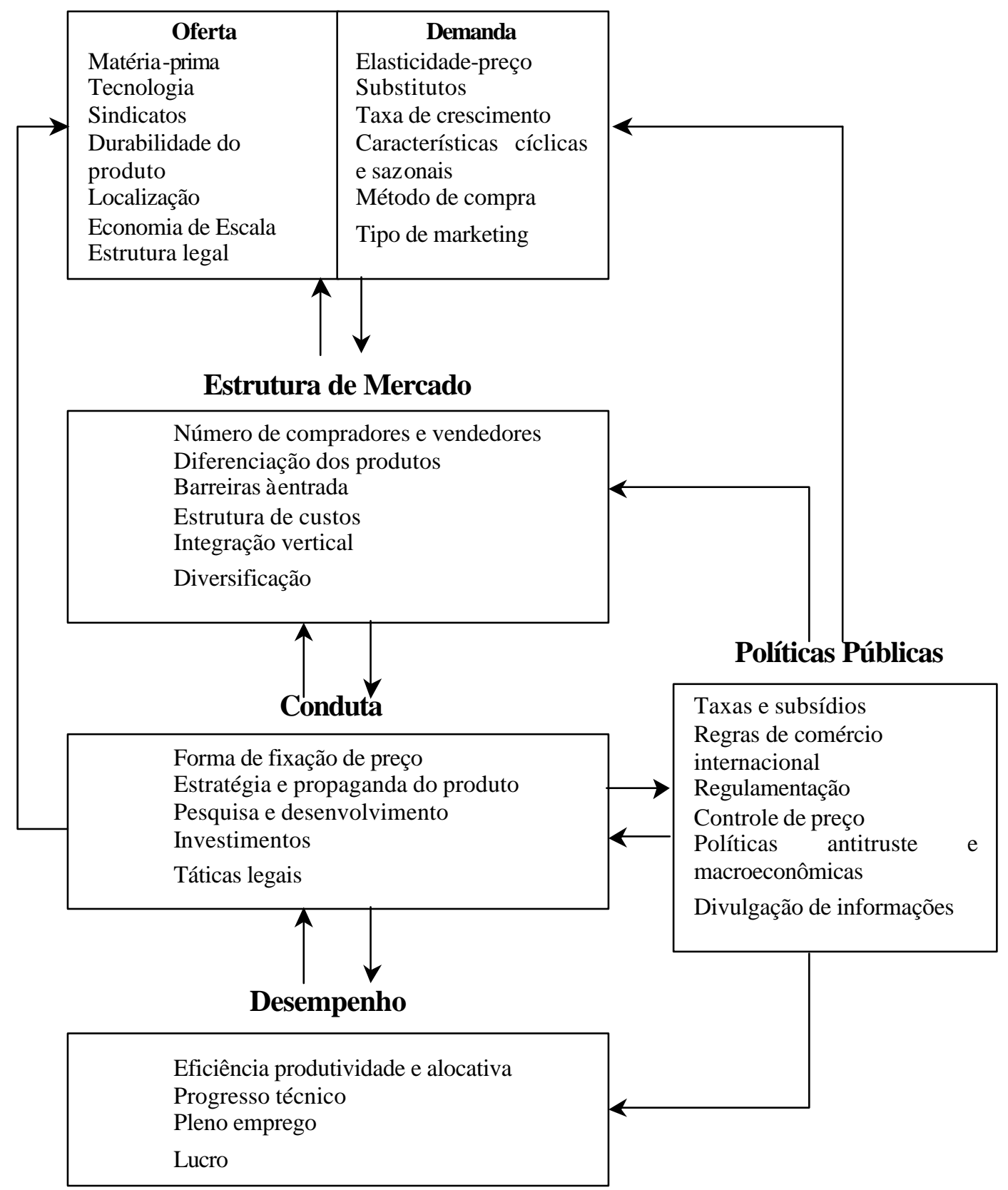

Figura 1 - Relações entre estrutura, conduta e desempenho.

Fonte: Adaptado de Carlton \& Perloff (1994) e Scherer \& Ross (1990) 
As políticas públicas podem influenciar a estrutura, a conduta e o desempenho da indústria. Leis, por exemplo, podem afetar o número de firmas em um mercado exigindo a existência de monopólio estatal, ou, inversamente, incentivar a entrada de empresas através de incentivos, alterando características de estrutura de mercado. $\mathrm{O}$ governo pode, igualmente, alterar os investimentos das indústrias através de políticas econômicas, tais como taxa de juros, política cambial etc., modificando a conduta das firmas. O desempenho das firmas acaba, portanto, sendo influenciado pelas políticas públicas, tanto indiretamente, através da mudança na conduta, como diretamente com, por exemplo, políticas macroeconômicas que influenciam o lucro.

Segundo Scherer \& Ross (1990), entretanto, existem efeitos de resposta (feedback), que são inversos ao sentido a cima apresentado. Os autores exemplificam afirmando que a pesquisa e desenvolvimento, relacionados à conduta das empresas, podem alterar a tecnologia de uma determinada indústria, modificando os custos e/ou o grau de diferenciação dos produtos. O comportamento dos vendedores, em relação à política de preços, pode resultar na entrada ou saída de firmas do mercado, o que resulta em modificações na estrutura de mercado.

Pesquisa em tecnologia, ainda, pode modificar as características do produto, alterando a substitutibilidade por outros produtos, ou, ainda, alterar processos produtivos, influenciando na economia de escala da produção. Ambas alterações modificam as condições básicas de uma indústria (Scherer \& Ross, 1990).

Ainda para Scherer \& Ross (1990), as variáveis das condições básicas e da estrutura de mercado são endógenas ao modelo, ou seja, são determinadas pelas relações de todo o sistema. Em alguns casos, o sentido de influência da estrutura para conduta e desempenho é fraco e o efeito de resposta, forte, modificando o sentido de influência.

Desta forma, segundo a Organização Industrial, a conduta e o desempenho das empresas são determinadas de forma conjunta. Segundo Sutton (1992), citado por Farina et al. (1997, p.25), "as estruturas de mercados apresentam determinantes tecnológicos (subaditividade de custos de produção, distribuição e de transação) que, combinados 
com as estratégias empresariais (investimento em pesquisa e desenvolvimento, propaganda, concorrência de preços, produtos etc.) vão resultar em diferentes padrões de concentração".

Entretanto, a ordem de casualidade acima apresentada (estrutura - conduta desempenho, Figura 1) não é consenso dentro da Organização Industrial. Sutton (1992) apresenta a conduta como base para a estrutura e desempenho. Segundo o autor, características do mercado, como sunk cost exógenos (investimentos necessários para se entrar no mercado, como em máquinas, que são obrigatórios pelas características do mercado) e sunk cost endógeno (variável relacionadas aos dispêndios nos quais o investidor tem maior controle, como gastos em propaganda e pesquisa $\mathrm{e}$ desenvolvimento) interagem e determinam uma configuração de equilíbrio da estrutura de mercado, dependendo da intensidade da concorrência.

Farina (2000) introduz outro esquema para o paradigma da estrutura-condutadesempenho, no qual inclui definições de Economia dos Custos de Transação, teoria que será vista no próximo item. Segundo a autora, o Ambiente Competitivo (composta pela estrutura da indústria, padrões de concorrência, característica de consumo etc.) interrelaciona-se com Ambiente Organizacional (que incorpora os sindicatos, institutos de pesquisa, políticas setoriais privadas etc.), com o Ambiente Institucional (que engloba o sistema legal, tradições e costumes, políticas macroeconômicas etc.) e com Ambiente Tecnológico (paradigma e fase da trajetória tecnológica), e que se relacionam entre si.

No Ambiente Competitivo, há formação de grupos estratégicos, influenciados pelos ambientes citados anteriormente, que se relacionam com os atributos das transações e por sua vez, determinam as estruturas de governança². Estas duas últimas influenciam as Estratégias Individuais (que englobam as diferenciações, segmentação, inovação etc.). Isso tudo se considerado o curto prazo. No longo prazo as estratégias

\footnotetext{
2 Estrutura de govemança pode ser definida como "a matriz institucional na qual a integridade das transações é determinada. No setor comercial, três estruturas de governança distintos são comumente reconhecidas: o mercado, híbrido e hierárquico" (Williamson, 1996, p.378).
} 
individuais e coletivas determinam o ambiente competitivo, organizacional, institucional e tecnológico (Farina et al., 1997). O importante é notar que a ordem de casualidade ainda é objeto de estudo e depende de muitas variáveis.

O exercício do poder de mercado é uma das principais preocupações da Organização Industrial, pois, em uma economia capitalista, as ações empresariais são voltadas para a obtenção de lucros econômicos. Este resultado pode ser alcançado pelo exercício do poder de monopólio previamente conquistado, permitindo à firma arbitrar sobre a oferta do mercado e seus preços. A conquista e a manutenção de uma posição dominante é causada pelas diferenças entre os concorrentes efetivos e potenciais, e está relacionada à eficiência das firmas. A eficiência pode representar uma barreira a entrada de novos competidores, bem como uma vantagem sobre os rivais existentes. Portanto, configurações eficientes de mercado dependem da existência de forte pressão competitiva (Farina et al., 1997).

A Organização Industrial fornece referencial teórico para a estimativa dos índices que buscam refletir o poder de monopólio, e, portanto, a pressão competitiva.

Scherer (1970) apresenta três maneiras para o cálculo do poder de monopólio. A primeira, denominada de índice de Lerner ${ }^{3}$, reflete a relação entre preço e custo marginal com o monopólio. Se o índice for zero, ou seja, o custo marginal é igual ao preço, então se encontra em competição perfeita. Conforme o mercado afasta dessa condição, a diferença entre preço e custo marginal aumenta e o valor do índice cresce. Este método, segundo Carlton \& Perloff (1994), esbarra na dificuldade em se obter os custos marginais.

A segunda forma apresentada pelo autor enfatiza a sensibilidade das vendas de uma empresa em relação às mudanças no preço do produto do concorrente (quanto

${ }^{3} M=\frac{\text { Preço-CustoMarginal }}{\text { Preço }}$ 
maior a sensibilidade, menor o poder de monopólio). Pode-se utilizar, para tanto, a elasticidade-demanda cruzada, ou seja, a mudança percentual nas vendas de uma firma associado a uma alteração percentual no preço de outra firma, tudo mais constante. A dificuldade deste método está em obter os dados necessários.

O terceiro e mais utilizado método, baseia-se na teoria econômica que sugere que o grau de competição em um mercado possui relação positiva com o número de empresas desse mercado e utiliza variáveis observáveis da estrutura de mercado. Entretanto, a distribuição da participação de cada firma no mercado relevante é importante para a análise de poder de monopólio. Assim sendo, Scherer (1970) apresenta outros três índices (razão de concentração, índice de Hirschman-Herfindahl e índice de Gini) que buscam estimar essa distribuição.

No estudo de concentração de mercado, a definição de mercado relevante é muito importante, pois influencia diretamente no resultado e, por sua vez, no poder de monopólio das empresas. Conforme Scherer (1970), esta definição deve abranger a possibilidade de substituição tanto no consumo, quanto na produção. No lado da demanda, as firmas são concorrentes se seus produtos são substitutos na opinião dos compradores. Um modo para saber se isso ocorre é verificar se a elasticidade-demanda cruzada é elevada. Porém, devido à dificuldade em se obter os dados necessários para o cálculo da elasticidade, pode-se utilizar as características físicas dos produtos em questão, o que pode não apresentar o mesmo resultado que o método anterior. Carlton \& Perloff (1994) acrescentam que o grau de substituição depende também dos preços correntes dos produtos, pois a níveis de diferença de preços entre os produtos eles podem ser mais ou menos substitutos.

No lado da produção, deve-se observar dois pontos: (i) se existem empresas que não são rivais, porém que possuam sistemas de produção semelhantes e que possam tornar a ser concorrentes, (ii) e se há ou não barreiras à entrada no mercado (Scherer, 1970).

Contudo, o mercado não é restringido somente em termos de produtos, mas 
também em extensão geográfica do mercado. Segundo Carlton \& Perloff (1994), o limite geográfico de um mercado é determinado se o aumento de preço em uma localidade afeta substancialmente o preço em outro local. Este procedimento é semelhante ao utilizado para determinar a extensão do mercado de um produto.

Carlton \& Perloff (1994) apresentam a definição de mercado utilizado no Horizontal Merger Guidelines do Departamento de Justiça e da Comissão Federal de Comércio dos Estados Unidos. Segundo esse guia, um mercado é o menor grupo de produtos e a menor área geográfica no qual um monopólio hipotético poderia ter seus preços aumentados de forma eficaz e permanente. A Secretaria de Acompanhamento Econômico do Ministério da Fazenda no Guia de Análise Econômica de Atos de Concentração apresenta definição semelhante de mercado relevante.

De acordo com os autores, o mercado pode, ainda, ser classificado conforme o número de compradores e vendedores e as barreiras à entrada. A relação entre essas variáveis resultam em seis estruturas de mercados, apresentadas no Quadro 2.

\begin{tabular}{|l|c|c|c|c|}
\hline \multirow{2}{*}{ Estrutura de Mercado } & \multicolumn{2}{|c|}{ Vendedores } & \multicolumn{2}{c|}{ Compradores } \\
\cline { 2 - 5 } & Barreiras àentrada & Número & Barreiras àentrada & Número \\
\hline Competição & Não & Muitos & Não & Muitos \\
\hline Monopólio & Sim & Um & Não & Muitos \\
\hline Monopsônio & Não & Muitos & Sim & Um \\
\hline Oligopólio & Sim & Poucos & Não & Muitos \\
\hline Oligopsônio & Não & Muitos & Sim & Poucos \\
\hline Competição monopolista & Não & Muitos & Não & Muitos \\
\hline
\end{tabular}

Quadro 2 - Estruturas básicas de mercado.

Fonte: Carlton \& Perloff (1994, p.7)

Em mercados competitivos, as firmas são tomadoras de preço, ou seja, devem-se preocupar apenas com a quantidade produzida, pois o preço de mercado é independente do volume de produção individual. A ação de cada empresa não é percebida pelas demais devido à pequena participação no mercado global. Nesses mercados, a ausência de barreiras à entrada permite livre mobilidade de recursos proporcionando que se deslocam de um setor para outro em busca de oportunidades mais lucrativas. 
Em uma estrutura de mercado monopolista, existem altas barreiras à entrada de outras empresas e apenas uma firma supre o mercado. Desta forma, ela pode fixar preços acima do nível do mercado competitivo, exercendo o seu poder de mercado. Em mercados monopsonistas, nos quais existe apenas um comprador, a demanda da firma influencia o preço do insumo. Neste caso, a empresa adquire o insumo até que o custo marginal de empregar uma unidade extra deste exceda o preço do fator, desta forma o monopsonista compra um preço abaixo ao do mercado de fatores competitivo.

Entre essas duas formas de estruturas tem-se o oligopólio, no qual existe mais de uma firma no mercado, mas não em número suficiente para negligenciar a contribuição individual (Ferguson, 1996). Desta forma, existe interdependência entre as decisões das firmas, tanto nas estratégias de fixação de preço, quanto de quantidade produzida.

A competição monopolista ocorre em um mercado em que mais de uma empresa produz bens ou serviços similares e não idênticos, ou seja, cada firma tenta diferenciar seu produto das demais empresas na indústria. Com isso, as firma são consideradas monopolistas por se depararem com uma curva de demanda negativamente inclinada para seu produto, isto é, possui certo poder de estabelecer seu preço. Contudo, as empresas competem pelos clientes em termos de preços e produtos. Nesse mercado, ainda, não há restrições a entrada de novas empresas, como ocorre nas indústrias competitivas (Varian, 1994). Carlton \& Perloff (1994) afirmam que, em competição monopolista, as firmas podem fixar os preços acima do nível do mercado competitivo, mas não obtém lucro.

Conforme Scherer \& Ross (1990), em mercados monopolistas, oligopolistas e competição monopolista, todas as firma reconhecem que suas decisões do volume de produção têm efeito nos preços. Isto é, sob certas condições, as firmas só podem aumentar suas vendas se reduzirem os seus preços. Nesses três mercados, as firmas possuem, segundo os autores, alguma forma de poder sobre os preços, que é considerada como poder de monopólio ou de mercado.

Diferentemente das estruturas de mercado monopolistas e competitivas que 
possuem resultados conhecidos, para Scherer \& Ross (1990), o equilíbrio em um oligopólio depende das estratégias adotadas pelas firmas, ou seja, as escolhas das firmas dependem das suposições sobre as decisões e reações das rivais. Quando as empresas, por exemplo, escolhem fixar os preços simultaneamente e deixam o mercado determinar a quantidade vendida, temos o modelo de Bertrand. Segundo este modelo, os consumidores têm informação perfeita, percebem os produtos como idênticos e adquirem sempre da empresa que vender ao menor preço (Carlton \& Perloff, 1994).

No modelo de Bertrand estático, o nível de preços é escolhido uma única vez pelas empresas, cada firma acredita que o preço do concorrente é fixo e se praticar um valor pouco abaixo ao do rival terá acesso a todo o mercado. Neste caso, o equilíbrio de Bertrand é semelhante ao mercado de competição perfeita, no qual todas as firmas não têm lucro (o preço é igual ao custo marginal), pois o lucro não pode ser aumentado reduzindo-se ou elevando-se os preços (Carlton \& Perloff, 1994).

Contudo, de acordo com Scherer \& Ross (1990), o modelo de Bertrand pode resultar em um equilíbrio semelhante ao de monopólio. Os autores afirmam que versões de jogos estáticas (não-seqüenciais) de multiperíodos possuem duas categorias; uma relacionada aos "jogos repetidos" e outra aos "superjogos". No primeiro, os jogadores devem criar estratégias para um jogo de período simples, mas repetido sucessivamente $\mathrm{T}$ vezes. No segundo, o jogo de período simples repete-se infinitas vezes. A ação em uma jogada não interfere no período seguinte, pois as firma não aprendem com o passado, já que os jogadores são considerados perfeitamente informados.

Nos superjogos baseados no modelo de Bertrand, o preço de monopólio pode ser um equilíbrio de $\mathrm{Nash}^{4}$. As empresas, neste jogo, têm incentivo para manter o preço de monopólio. Reduzir o valor do produto, para capturar todo o mercado por um único

\footnotetext{
${ }^{4} \mathrm{O}$ equilíbrio de Nash é um conjunto de estratégias que, dado as estratégias de todas as outra firmas constantes, nenhuma empresa consegue obter um lucro maior escolhendo uma estratégia diferente. Desta forma, em um equilíbrio de Msh nenhuma firma quer mudar de estratégia (Carlton \& Perloff, 1990, p.233).
} 
período e obter o lucro de monopólio por desertar $\left(\pi^{\mathrm{M}}\right)$, pode significar a perda na participação dos ganhos de monopólio das jogadas futuras. Neste jogo, o lucro da firma em cada lance é dado pelo lucro de monopólio dividido pelo número de firmas $\left(\pi^{\mathrm{M}} / \mathrm{n}\right)$. O valor presente dos ganhos futuros da firma, por dividir os lucros de monopólio, é, portanto, $\left[\pi^{\mathrm{M}} /(\mathrm{nr})\right]$, onde $\mathrm{n}$ representa o número de firmas e o $\mathrm{r}$ a taxa de juros. Desta forma, se (nr) for menor do que um, as firmas não terão incentivo para reduzir os preços (Scherer \& Ross, 1990).

Entretanto, ainda de acordo com os autores, nada obriga as firmas praticarem preços de monopólio. Qualquer valor que seja abaixo deste preço pode acarretar em um equilíbrio, desde que o resultado do lucro da indústria $\left(\pi^{*}\right)$ satisfaça a seguinte condição $\left[\pi^{*} /(\mathrm{nr})\right]>\pi^{\mathrm{M}}$ (Scherer \& Ross, 1990).

Nos jogos repetidos finitas vezes, contudo, o equilíbrio de Nash é o mesmo do jogo estático, ou seja, o preço do oligopólio é semelhante ao do mercado competitivo. Isto ocorre porque em um jogo com $\mathrm{T}$ períodos, por exemplo, no qual todas as firmas cobram o preço de monopólio até o período F1, no período T, o jogo tem as mesmas características de um jogo de um único período, cuja estratégia ótima é reduzir o preço. Como a ação de um período não interfera no outro, então a estratégia de reduzir o preço em T-1 também é valida, bem como nos demais períodos, resultando em um preço de mercado competitivo em todos os períodos (Scherer \& Ross, 1990).

Entretanto, existem, segundo Carlton \& Perloff (1994), mercados nos quais uma empresa, ou algumas poucas, denominadas firmas dominantes ou líder, possuem uma grade participação no mercado e um número grande de pequenas firmas, chamadas de franja, que são tomadoras de preço e têm representação individual pequena, mas coletivamente apresentam uma participação substancial do mercado.

Os autores discutem, primeiramente, quais os fatores que fazem algumas empresas serem dominantes e outras não. Para eles, três razões são suficientes para criar esse tipo de estrutura de mercado: (i) a firma dominante possui custos menores do que a 
franja (ou por ser mais eficiente que as rivais, ou por ter iniciado as atividades antes e com isso ter menores custos de aprendizado e/ou ter alcançado a uma escala de produção ótima antes das demais), (ii) ela têm um produto superior ou (iii) um grupo de firmas podem agir conjuntamente como uma firma dominante (Carlton \& Perloff, 1994).

Para análise deste mercado, os autores assumem dois tipos extremos de mercado, um no qual não há entrada de novas empresas e outro, onde a entrada é livre e imediata. Assumem também que (i) existe uma empresa que é muito maior do que as demais por causa de seu custo de produção menor, (ii) todas as empresas são tomadoras de preço, exceto a dominante, (iii) a firma dominante conhece a curva de demanda do mercado, que possui produto homogêneo e um preço único e (iv) a firma dominante também sabe a curva de oferta da franja, ou seja, o quanto este vai produzir a cada nível de preço.

Em mercados em que não há entrada de novas firmas, a produção ótima da firma dominante, que maximiza o lucro, é determinada por um procedimento de dois passos. No primeiro, determina-se a função de demanda residual (demanda total menos a oferta da franja), e, no segundo passo, maximiza-se, como um monopolista, a função lucro a partir dessa demanda residual (Carlton \& Perloff, 1994). Ou seja, a um determinado preço, escolhido pela firma líder, as firmas menores estabelecem seu nível de produção, comportando-se como estivessem em um mercado de competição perfeita, pois enxergam a curva de demanda como horizontal e, portanto, produzem na quantidade em que o custo marginal se iguala ao preço. $O$ preço escolhido deve ser aquele que maximize o lucro da firma dominante, dado que a franja produziu tudo o que deseja naquele valor (Ferguson, 1996).

Nesse mercado, dependendo do nível de preços estabelecido pela firma dominante, as firmas da franja podem ter lucro econômico (mesmo de longo prazo, pois não ocorre entrada de novas empresas) ou não. Além disso, as firmas dominantes podem ainda tirar as firmas pequenas do mercado, caso seus custos forem muito menores do que as demais e impuserem um preço abaixo do preço de fechamento das franja (ou seja, inferior ao custo médio mínimo), ficando com o monopólio (Carlton \& Perloff, 1994). 
Caso a entrada de firmas for livre, segundo Carlton \& Perloff (1994), a empresa dominante não consegue fixar preços altos como na situação anterior. Além disso, a franja não é capaz de obter lucro econômico de longo prazo, pois se isso ocorresse, novas empresas entram no mercado até o preço igualar-se ao custo médio mínimo da franja. Porém, como a empresa dominante possui custos menores do que os da franja, ela obtém lucros econômicos positivos.

Nos mercados nos quais a franja é composta por um número grande de firmas, continuam Carlton \& Perloff (1994), a curva de demanda é horizontal, como um mercado perfeitamente competitivo, e corresponde ao custo médio mínimo. A demanda residual, a qual a firma dominante maximiza seu lucro, é também horizontal, pois não pode cobrar acima do custo médio mínimo da franja. Neste caso, a líder maximiza o lucro igualando o custo marginal ao preço de mercado, como em competição perfeita. Mas, obtém lucro econômico, pois seus custos médios são inferiores ao da franja, como assumido.

A curva de demanda residual, neste caso, mantêm-se horizontal até atingir o consumo máximo naquele preço. Depois deste ponto, torna-se novamente negativamente inclinada, acompanhando a curva de demanda do mercado. Isto ocorre, pois, após saturar o mercado ao preço correspondente ao custo médio mínimo da franja, o aumento de consumo só será obtido com a redução nos preços. Porém, a partir deste ponto, nenhuma firma da franja oferta produtos, e, então, tem-se um caso de monopólio. As empresas dominantes, que tenham custos muito inferiores à franja, podem, portanto, praticar preços abaixo dos custos médios mínimos da franja, e, com isso, tira-las do mercado (Carlton \& Perloff, 1994).

Os autores concluem que o comportamento das empresas dominantes depende de dois principais fatores, a facilidade de entrada de novas firmas na franja e na grandeza da diferença de custos entre as firmas dominantes e da franja. Caso a entrada seja livre e diferença entre os custos da empresa líder e da franja não for muito grande, a primeira não poderá cobrar valores acima do preço competitivo. Ainda de acordo com Carlton \& 
Perloff (1994), mesmo que a firma líder esteja só no mercado, como um monopólio, a possibilidade de entrada de uma franja faz com que a os preços fixados por ela sejam menores do que o valor que maximiza o lucro.

\subsection{Economia dos Custos de Transação (ECT)}

A Nova Economia Institucional (NEI) tem sua origem e consolidação nos trabalhos de Coase, Commons, Knight, Barnard na década de 30 e posteriormente nos de Hayek (Azevedo, 1996).

Commons, segundo Azevedo (1996), contribuiu sugerindo que a transação fosse utilizada como unidade de análise, em um período em que as firmas eram vistas como indivisíveis. Ainda segundo o autor, Knight sugeriu que a redução dos desperdícios era o principal propósito para se entender as organizações econômicas. Barnard e Hayek colaboraram ao introduzir que o principal problema econômico era a questão da adaptação às mudanças no ambiente econômico, em uma época em que se enfatizava os exercícios de estática comparativa (Azevedo, 1996).

Farina et al. (1997) explicam que Coase considera aspectos da organização ou de relacionamento com clientes e fornecedores, passando a considerar os aspectos internos da firma, que não eram tratados pela Teoria Neoclássica. Coase, para Azevedo (1996), centra sua análise em duas formas abstratas de coordenação: mercado e firma. A coordenação que apresentar o menor custo associado é considerada a mais eficiente. Porém, Coase admite a importância das formas intermediárias entre esses extremos (arranjos contratuais). Para o autor, a coexistência das diferentes formas de coordenação ocorre em virtude dos diferentes custos de utilização de cada uma.

Segundo Coase, a constituição de uma firma ocorre por haver custos em usar o mercado para alocação de fatores de produção. Estes custos consistem em descobrir quais são os preços relevantes e em negociar e concluir um contrato para cada transação. Como tais custos diferem dos custos de transformação (relacionados à tecnologia empregada), foram denominados custos de transação (Azevedo, 1996). 
A proposição original de Coase, que relaciona a forma organizacional aos custos de transação, permaneceu à margem da teoria econômica por cerca de trinta anos, pois, segundo Azevedo (1996), não se tratava de uma hipótese refutável. Os custos de transação, como apresentados, não são facilmente observáveis ou mensuráveis e não é possível realizar as comparações necessárias entre os diferentes mecanismos de coordenação para avaliar suas eficiências, portanto, não permite testes empíricos.

As idéias fundamentais de Coase, por serem bastante genéricas, inspiraram trabalhos em diversas áreas, o que permitiu o desenvolvimento de linhas de pesquisas independentes entre si. As correntes denominadas Ambiente Institucional e Instituições de Governança (ou Economia dos Custos de Transação - ECT) são particularmente importantes por apresentarem complementaridade entre si, pois tratam o mesmo objeto a economia com custos de transação - em níveis analíticos distintos (Azevedo, 1996). A primeira enfatiza um estudo microanalítico das transações, influenciado principalmente pelos trabalhos de Oliver Williamson. A segunda, Ambiente Institucional, enfoca a análise das regras do jogo, ou seja, das macroinstituições, tendo Douglas North como principal representante. As relações entre essas correntes podem ser resumidas pela Figura 2.

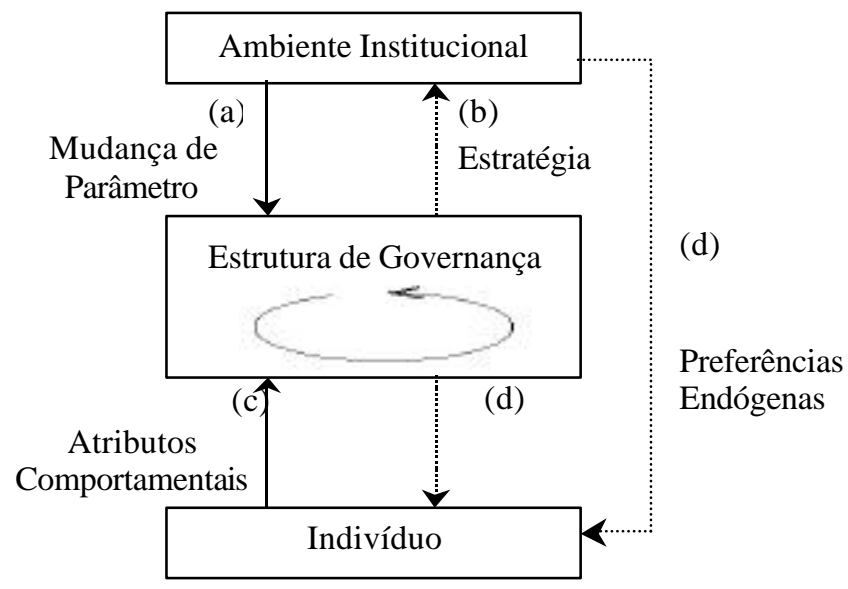

Figura 2 - Relações entre arranjo e Ambiente Institucional.

Fonte: Adaptado de Williamson (1996) 
Williamson (1996) explica as relações da Figura 2 afirmando que a estrutura de governança não opera isoladamente, pois a eficiência entre suas alternativas varia conforme o ambiente institucional e os atributos econômicos dos participantes. As setas sólidas representam os efeitos principais e as pontilhadas os efeitos secundários. $\mathrm{O}$ ambiente institucional define a regra do jogo, e, conforme mostra a seta (a), condiciona o aparecimento e a seleção de formas organizacionais. Mudanças nos direitos de propriedade, leis contratuais, normas, costumes, entre outros, induzem alterações nos custos comparativos de governança que, por sua vez, causa uma reconfiguração da organização econômica que lhe são subentendidos (Williamson, 1996).

A relação inversa, representada pela seta tracejada (b), expressa a capacidade de alteração do Ambiente Institucional por parte das instituições. Tais alterações podem ser realizadas através de lobby que visam, por exemplo, alterar a legislação vigente, modificando as regras do jogo. Este efeito, porém, não é foco de análise da NEI (Azevedo, 1996).

A ação do Indivíduo sobre o Arranjo Institucional, representada pela seta (c), tem um papel importante no arcabouço teórico da NEI. Essa ação ocorre através dos atributos comportamentais dos indivíduos - racionalidade limitada e oportunismo - que são condições necessárias para a ocorrência de custos de transação. Segundo Williamson (1996, p.223), a seta circular, dentro da governança, representa a proposição que a organização tem "vida própria".

Os Indivíduos igualmente sofrem efeitos secundários tanto do Ambiente Institucional como do Arranjo Institucional, representado pelas setas tracejadas (d), pois eles influenciam nas 'preferências endógenas' dos indivíduos, embora esta relação não seja o foco de análise da NEI (Azevedo, 1996). Williamson (1996) acrescenta que a propaganda ou outras formas de educação pode formar as 'preferências endógenas'.

Portanto, o Ambiente Institucional enfoca mais o papel das instituições que são formadas pelo homem para estruturar a interação social, política e econômica. Segundo Zylbersztajn (1995, p.47), as formas alternativas de governança podem ser deslocadas 
devido a mudanças no ambiente institucional. Por causa dessas características, faz-se necessário um estudo profundo sobre as instituições e o ambiente institucional em que ocorrem. A instituição é constituída, segundo North $(1994)^{5}$, citado por Farina et al. (1997), pelas regras do jogo de uma sociedade, que consistem nas restrições estabelecidas pelo homem para disciplinar as interações humanas. Essas restrições, segundo o autor, podem ser formais, como a constituição, leis e direitos de propriedade, ou informais, como sanções, tabus, costumes, códigos de conduta etc.

Segundo Farina et al. (1997), o Ambiente Institucional, visando analisar o papel das instituições, segue dois caminhos. Um investiga os efeitos de uma mudança no ambiente institucional sobre os resultados econômicos, e o outro teoriza sobre a criação das instituições. Para tanto, tem como base o reconhecimento do intercâmbio entre especialização e custos de transação.

As idéias de Williamson, baseadas nas preposições de Coase, adotam a transação como unidade analítica, que "ocorre quando um bem ou serviço é transferido através de interfaces tecnologicamente separáveis" (Williamson, 1987, p.1). A firma é vista como um nexo de contratos que disciplinam essas transações.

Para Williamson, as transações possuem certos atributos, como especificidade dos ativos envolvidos, a incerteza e a frequiência, que definem seus custos. Os custos de transação, segundo Cheung (1990) ${ }^{6}$, citado por Azevedo (1996), são os custos com elaboração e negociação dos contratos, mensuração e fiscalização de direitos de propriedade, monitoramento do desempenho e organização de atividades. Azevedo (1996) acrescenta a esta definição as contribuições de Barnard e Hayek, incluindo os custos de adaptações ineficientes às mudanças do sistema econômico.

\footnotetext{
5 NORTH, D. Custos de transação, instituição e desempenho econômico. Rio de Janeiro: Instituto Liberal, 1994. 38p.

${ }^{6}$ CHEUNG, S. On the New Institutional Economics. In: Cheung, S. et al. Contract Economics, 1990. p.48-75.
} 
Os custos de transação podem ser classificados como custos ex-ante (elaboração do contrato) ou ex-post (monitoramento e incentivo dos agentes para a realização da transação dentro do contrato), dependendo se ocorreram antes ou depois do fechamento do contrato, respectivamente.

Para a Economia dos Custos de Transação, portanto, os dois pressupostos comportamentais, racionalidade limitada e comportamento oportunista, juntamente com os atributos das transações e o ambiente institucional, definem as formas organizacionais mais eficientes (Moraes, 2000). A seguir, serão apresentados tais conceitos.

\subsubsection{Pressupostos comportamentais}

A ECT, como citado anteriormente, assume como pressupostos o comportamento oportunista e a racionalidade limitada dos agentes (Williamson, 1987), que são diferentes dos pressupostos da Teoria Neoclássica (racionalidade ilimitada). O primeiro considera que os agentes podem adotar comportamento oportunista em algum momento, ou seja, são auto-interessados com avidez e podem agir aeticamente quando lhes convêm, tornando necessário estipular mecanismos de fiscalização e controle nos contratos, o que implica aumento dos custos.

Quando o comportamento oportunista ocorre antes do fechamento do contrato, é denominado de seleção adversa (adverse selection) e quando ocorre após o fechamento é chamada de risco moral (moral hazard). Este comportamento pode acontecer devido à informação incompleta, imperfeita ou assimétrica. Deste modo, a ECT permite o relaxamento da premissa da teoria neoclássica de informação perfeita.

Segundo Farina et al. (1997), a importância desse pressuposto está relacionada aos problemas de adaptação decorrentes da incompletude dos contratos. Mesmo que a ação oportunista não ocorra, basta a possibilidade do agente portar-se desta maneira para se justificar a inclusão de salvaguardas contratuais.

A racionalidade limitada refere-se ao comportamento que aspira a ser racional, 
porém o faz de forma restrita. Isto decorre da capacidade limitada dos agentes em receber, estocar, recuperar e processar a informação (Williamson, 1996). Isto implica que as decisões dos agentes não são necessariamente iguais às obtidas utilizando-se a racionalidade plena. Desta forma, o recurso 'racionalidade' é considerado escasso, resultando em custos em sua utilização (Azevedo, 1996).

Como os agentes não conseguem prever todos os eventos futuros, os contratos são incompletos. Desta forma, estimulam os agentes a incluir salvaguardas que permitam alterações nos contratos e reduzam os comportamentos oportunistas, elevando os custos de transação.

\subsubsection{Dimensões das transações}

Para a Economia dos Custos de Transação, "a organização dos mercados resulta da minimização dos custos de transação, que variam de acordo com os atributos dessas transações" (Farina et al.,1997, p.25). Esses atributos são considerados exógenos ao modelo.

Como os custos de transação não são observáveis, não servem para comprovação empírica das teses desenvolvidas pela NEI. Porém, os atributos das transações, freqüentemente observáveis, podem ser utilizados como elementos explicativos dos custos de transação, eliminando o obstáculo aos estudos empíricos. Os custos de transação são, portanto, uma função no espaço n-dimensional, no qual cada atributo representa uma dimensão e o arranjo institucional, construído para reduz tais custos, é mantido constante (Azevedo, 1996).

A ECT adota três dimensões das transações: (i) especificidade dos ativos, (ii) frequiência e (iii) incerteza. Cada um deles será apresentado a seguir.

\subsubsection{Especificidade dos ativos}

A especificidade dos ativos envolvidos nas transações refere-se à possibilidade de utilizar os ativos em outras finalidades sem a redução de seu valor. Assim, quanto 
maior a especificidade, menor o valor do ativo em outros usos e, portanto, maior o risco envolvido na transação, o que gera aumento no custo.

A diferença entre o retorno do ativo empregado em uma transação específica e seu retorno em um emprego alternativo gera uma quase-renda. Esta quase-renda é disputada pelas partes envolvidas, na medida em que sua geração depende da continuidade do negócio. Como transações específicas tendem a desenvolver dependência bilateral e devido ao comportamento oportunista dos envolvidos há a possibilidade dos agentes exercerem poder monopolístico sobre as quase-rendas. Isto pode gerar conflitos entre as partes e problemas de adaptação dos contratos, elevando os custos de transação (Ribeiro, 1998).

Williamson (1996) divide a especificidade em seis tipos: (i) locacional (envolve as distâncias entre as firmas, custos de transporte e armazenamento); (ii) física (referente ao uso do ativo); (iii) humana (relacionado ao treinamento de mão de obra); (iv) especificidade de marca; (v) ativos dedicados (investimento em bens que não têm usos alternativos); (vi) especificidade temporal (referente ao período no qual a transação ocorre).

A importância da especificidade dos ativos está diretamente relacionada aos pressupostos comportamentais (racionalidade limitada e oportunismo) e à incerteza (Williamson, 1987). Quanto maior a especificidade dos ativos, maior a possibilidade de ações oportunistas - resultado da incompletude do contrato e da criação da quase-renda e, portanto, maiores as incertezas. Desta forma, segundo Azevedo (1996), caso a racionalidade limitada não ocorresse, os contratos seriam completos, impossibilitando ações oportunistas. Assim, os problemas relacionados à dependência dos agentes, criados pela especificidade dos ativos, não existiriam.

Para Williamson (1996), existe relação entre a escolha do tipo de governança e a especificidade dos ativos. Cada tipo de governança apresenta diferentes níveis de custo e controle sobre uma transação, dada a especificidade do ativo. Transações via mercado apresentam um grau menor de controle do que via contratos de longo prazo, e são 
menores do que em relação à integração vertical. Segundo o autor, a dependência bilateral entre o fornecedor e o comprador aumenta conforme o ativo torna-se mais específico, pois estes perdem valor para usos alternativos.

Williamson (1996) propõe um modelo analítico conhecido como "forma reduzida", que relaciona o grau de especificidade dos ativos envolvidos ao custo de governança. O modelo utiliza como variável chave a especificidade dos ativos (k). As dimensões da transação (incerteza e frequiência) e os elementos do ambiente institucional (como definição e garantia dos direitos de propriedade, formas e estilo de governo, disponibilidade de informações) são incorporados ao modelo como parâmetros que deslocam as funções $(\theta)$.

Para o autor, a tendência de se utilizar a governança via hierárquica ${ }^{7}$ cresce à medida que o grau de especificidade for maior. Isto ocorre devido ao aumento do custo de monitoramento da transação e dos custos de modificações dos ativos, via mercado. Esta relação pode ser observada na Figura 3, que representa as três funções de custo.

\footnotetext{
${ }^{7}$ Hierarquia pode ser definida como "transações que ocorrem sob uma mesma propriedade (compradores e ofertantes são da mesma empresa) e sujeitos a um controle administrativo (uma relação de autoridade que inclui o poder fiat) geridos por uma estrutura hierárquica." (Williamson, 1996, p.378)
} 


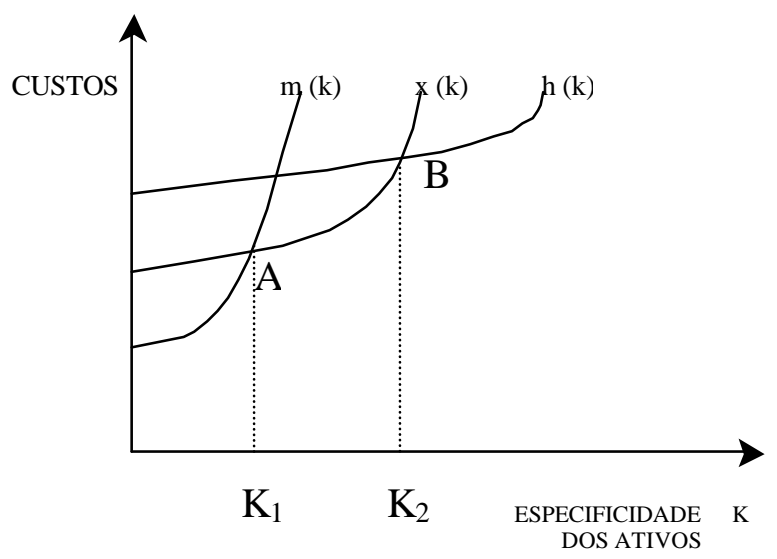

Figura 3 - Custo de estrutura de governança e nível de especificidade dos ativos.

Fonte: Williamson (1996, p.108)

Sendo:

$\mathrm{k}=$ especificidade de ativos e $\theta=$ vetor de parâmetro de deslocamento

$\mathrm{m}(\mathrm{k}, \theta)=$ função custo da governança via mercado

$\mathrm{x}(\mathrm{k}, \theta)=$ função custo da governança via contratual ou híbrida

$\mathrm{h}(\mathrm{k}, \theta)=$ função custo da governança via hierárquica

$\mathrm{e}$

$\mathrm{M}^{\prime}>\mathrm{X}^{\prime}>\mathrm{H}^{\prime}>0$, onde o apóstrofo corresponde à derivada da função em relação a k

Considerando que níveis menores de especificidade necessitam de menor grau de controle e que o mercado promove adaptações mais eficientes quando as especificidades dos ativos são negligenciáveis, Williamson (1996) assume que: $\mathrm{m}(0, \theta)<\mathrm{x}(0, \theta)<\mathrm{h}$ $(0, \theta)$. Isto é, para um nível de especificidade nula, o mercado é mais eficiente do que o modo híbrido ${ }^{8}$, que, por sua vez, é mais eficiente do que a forma hierárquica, o que é observável pela posição dos interceptos das três funções custos.

O modelo proposto representa igualmente que, conforme aumenta a especificidade do ativo, ocorre o aumento da dependência bilateral - portanto,

8 "Relações contratuais de longo prazo, que preservam a autonomia, mas estabelecem maiores salvaguardas sobre especificidade das transações do que ocorre com o as transações via mercado" (Williamson, 1996, p.378). 
crescimento da necessidade de controle - e o aumento relativamente maior do custo de mercado, em relação às demais governanças. Isso pode ser apresentado como na Figura 3. As derivadas são positivas devido a essa dependência bilateral, aumentando os custos de governança sobre a transação, mantida a forma organizacional (Azevedo, 1996).

Na Figura 3, A e B são pontos onde os agentes são indiferentes em utilizarem as formas organizacionais via mercado ou híbrida, e, híbrida ou hierárquica, respectivamente. Os pontos $\mathrm{K}_{1}$ e $\mathrm{K}_{2}$ são graus de especificidade que delimitam a utilização de modos de governança mais eficientes, pois dada uma especificidade, os agentes procuram empregar a forma organizacional de menor custo.

Desta forma, quanto maior a especificidade de um ativo, maior a necessidade de controle sobre a transação e, portanto, maior a tendência das organizações saírem da governança via mercado para via contratual ou hierárquica.

\subsubsection{Frequiência}

A freqüência das transações apresenta aspectos importantes para os seus custos, pois permite a diluição dos gastos de adoção de mecanismos mais complexos e possibilita a construção de reputação por parte dos agentes envolvidos.

As transações podem ser ocasionais ou recorrentes. A primeira ocorre esporadicamente e, geralmente, se realiza via mercado, por não ser viável a construção de mecanismos para as reger. À medida que as transações possuem um caráter duradouro, ou seja, são recorrentes, o uso de contratos de longo prazo são mais eficientes, pois os custos de formulação dos contratos, coleta de informações e monitoramento são diluídos nas diversas transações.

A maior frequiência das transações pode ocasionar, ainda, a redução dos custos, pois possibilita (i) aos agentes se conhecerem, reduzindo a assimetria de informação e a incerteza, (ii) a criação de uma reputação (marca), diminuindo os astos de informação e criando um ativo específico e (iii) a formação de um 'compromisso confiável' entre as 
partes em torno da continuidade da relação. Esses fatores permitem, portanto, a redução da incerteza e dos custos a ela associados (Farina et al.,1997).

A repetição de uma transação possibilita o aprendizado entre os agentes, reduzindo a assimetria informacional dada ex-ante. Isto permite que se conheçam as idiossincrasias de cada parte, o que torna o resultado da transação mais previsível, reduzindo as incertezas (Azevedo, 1996).

Segundo Azevedo (1996), o objetivo da criação de uma reputação, ou marca, é reduzir os custos de coleta de informação por parte dos agentes. Desta forma, o cliente, ao adquirir um produto devido à sua boa reputação, está utilizando uma informação relevante ao processo de escolha sem custo de coleta de informação, reduzindo o custo de transação.

Porém, o autor afirma que para criar uma marca, a empresa tem gastos com marketing e controle de qualidade, aumentado o custo de transformação. Desta forma, a frequiência das transações resulta em reputação somente quando a redução nos custos de transação for superior aos aumentos dos custos de transformação.

O estabelecimento de um compromisso confiável está relacionado ao custo de oportunidade de se realizar uma ação oportunista. Desde que observável, esta ação apresenta maiores custos, conforme maior a perspectiva de continuidade da transação. Isto ocorre, pois, segundo Azevedo (1996), a penalidade do oportunismo pode ser a interrupção da relação, cujo custo é representado pelo valor presente descontado dos ganhos futuros desta relação. Desta forma, o comportamento oportunista é inibido desde que a ameaça de abandono do contrato seja confiável, o que ocorre quando a compensação que a vítima recebe pela ação oportunista é menor do que o rompimento do contrato.

Azevedo (1997) conclui que as promessas contratuais são plenamente confiáveis quando os ganhos de uma ação oportunista observável são menores do que o valor presente dos ganhos futuros. Assim, o compromisso confiável é suficiente para garantir 
o comportamento cooperativo dos agentes.

\subsubsection{Incerteza}

A impossibilidade de previsão dos eventos futuros e do comportamento estratégico dos agentes envolvidos nas transações, além da incapacidade dos agentes de processar todas as informações, resultado da racionalidade limitada dos agentes, tornam os contratos incompletos, resultando em incertezas, que podem, segundo Farina et al. (1997), ser de três formas. A primeira, designada como risco, está relacionada a um distúrbio que possui uma distribuição de ocorrência conhecida. A segunda, que é propriamente a incerteza, corresponde aos distúrbios que não possuem distribuição conhecida, ou seja, ignorância dos possíveis eventos futuros. A terceira forma enfatiza a incerteza em relação às informações relevantes ao contrato, ou seja, estão relacionados à informação incompleta e assimétrica.

Para Farina et al. (1997), as estruturas de governança tendem a ser mais ou menos suscetíveis às incertezas. A estrutura de governança via contratos, ou híbrida, é mais suscetível à variação dos eventos, pois adaptações contratuais não podem ser realizadas unilateralmente, como no caso do mercado, ou por decisão burocrática, como no caso da hierárquica. Por esse motivo, a ocorrência freqüente de distúrbios, tornando alto o grau de incerteza, pode tornar a forma híbrida inviável. A Figura 4 ilustra a relação entre a incerteza e a especificidade de um ativo. 


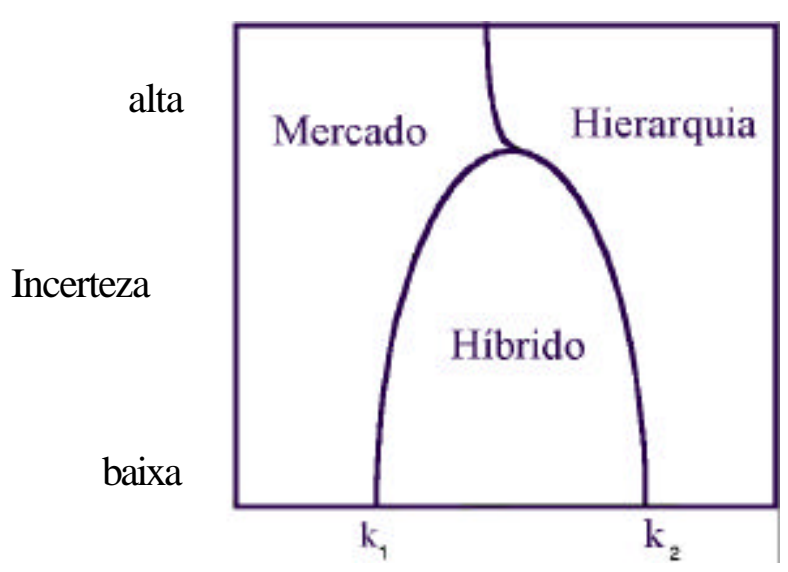

Especificidade dos ativos

Figura 4 - Estrutura de Governança resultante da relação entre incerteza e especificidade.

Fonte: Williamson (1996)

Portanto, segundo a ECT, quanto maior for a frequiência, especificidade do ativo e/ou a incerteza, maior a possibilidade da empresa deixar de utilizar o mercado aberto e passar a realizar contratos ou internalizar a transação. Isto ocorre devido aos aumentos dos custos envolvidos nas transações.

O aumento da especialização pode gerar ganhos - obtidos pela economia derivada da divisão de trabalho - que são reduzidos, ou até eliminados, pelo aumento dos custos de transação. As instituições, neste caso, teriam função de conciliar os movimentos contrários dos custos, buscando reduzir os custos de transação conforme aumenta a especialização. Desta forma, o ambiente institucional em que se nsere uma transação irá se adequar à complexidade do mundo visando viabilizar a transação (Farina et al., 1990).

\subsection{Relações verticais}

O objetivo do presente item é apresentar os conceitos e as idéias fundamentais de integração e restrição vertical, visando subsidiar a discussão sobre a formação das 
associações como forma de integração vertical.

Integração vertical ocorre quando uma firma participa em mais de um estágio da produção ou distribuição de bens e serviços (Carlton \& Perloff, 1994). A substituição de contratos e trocas no mercado por permutas dentro dos limites da firma é inerente à noção de integração vertical, porém não é suficiente, a firma deve ser dona e ter controle completo sobre os estágios de produção ou distribuição (Perry, 1992).

Segundo Carlton \& Perloff (1994), as empresas geralmente se integram visando à redução de custos ou a eliminação de externalidades de mercado. Apesar da integração poder envolver custos substanciais, como aumento dos custos administrativos e de produção ou distribuição (em relação aos do mercado), existem pelo menos seis grandes motivos em se integrar.

As firmas podem reduzir (i) custos de transação e (ii) incertezas de oferta da matéria prima, (iii) internalizar externalidades ${ }^{9}$, (iv) evitar intervenções governamentais, (v) criar ou aumentar poder de mercado ou (vi) eliminar ou reduzir o poder de mercado de outras empresas (Carlton \& Perloff, 1994, p.501-2). Perry (1992) aponta, além do custo de transação, outras duas determinantes para a integração: economias tecnológicas e imperfeições de mercado.

Através da integração, segundo Carlton \& Perloff (1994), custos de transação podem ser reduzidos (i) quando os ativos envolvidos são específicos do processo de produção, o que pode acarretar em dependência e risco de comportamento oportunista pelo fornecedor, (ii) pela diminuição do comportamento oportunista dos agentes; (iii) pela redução das incertezas relativas ao fornecimento, à qualidade, aos preços etc.; (iv)

\footnotetext{
${ }^{9}$ Externalidade pode ser definida, segundo Carlton \& Perloff (1994, p.115), como bens (como informação ou ar fresco) e "males" (como poluição e lixo) que não podem ser precificados, e que podem resultar em um equilíbrio não-ótimo na economia. Externalidade negativa são produtos, resíduos etc. (" males") não precificados e que causam algum dano à sociedade, reduzindo seu bem-estar. Quando não regulados pelo governo, ou não pagos pelas empresas causadoras dessa externalidade, leva a uma produção maior do que aquela que seria ótima em termos sociais. Esta distorção é identificada como falha de mercado. Externalidade positiva ocorre quando há aumento do bem-estar da sociedade, sem custo extra a ela.
} 
pelo melhor controle e acesso às informações e (v) pela melhoria da coordenação dos processos produtivos.

A redução de incerteza de oferta pode ser importante em mercados nos quais os preços não são eficientes para alocação de bens. Se há possibilidade de racionamento de insumos, por exemplo, as empresas são incentivadas a se integrar para assegurar o acesso à matéria-prima.

As firmas podem optar pela integração para internalizar externalidades (Carlton \& Perloff, 1994, p.505). Em busca de manter um padrão de qualidade no atendimento ao cliente, por exemplo, empresas podem verticalizar-se para frente ${ }^{10}$ e com isso criar uma reputação, colhendo os frutos de uma externalidade positiva. Isto pode reduzir, também, a possibilidade de que uma queda de qualidade de atendimento ao cliente que venha prejudicar a imagem da empresa, ou seja, que ocorra externalidade negativa.

Intervenções governamentais influenciam, também, a integração das firmas. Controle sobre preços de insumos, por exemplo, pode resultar em redução de sua oferta e, visando manter o suprimento, as empresas decidem integrar-se para trás. Impostos e taxas também são incentivos à integração vertical. Com essa ação, as firmas têm a possibilidade de transferir resultados de uma indústria, em que incidem maiores impostos, para outra, que possuem menos impostos. A regulamentação governamental também pode incentivar a integração vertical (ou horizontal), quando, por exemplo, o lucro de uma divisão da firma é regulamentado e as outras divisões, não (Carlton \& Perloff, 1994). De forma semelhante ao que ocorre com os impostos e taxas, as firmas transferem os resultados de uma divisão para outra, menos regulamentada.

Outro objetivo em se integrar verticalmente é buscar o aumento de lucros monopolistas. Carlton \& Perloff (1994) apontam duas formas de se obter esse lucro. A primeira, quando um monopolista vende um fator de produção importante a uma

\footnotetext{
${ }^{10}$ Integração ou verticalização para frente ocorre quando se avança no processo produtivo no sentido ao consumidor final; quando ocorre para trás, estende-se no processo produtivo no sentido aos insumos.
} 
indústria competitiva e a segunda, quando há possibilidade do monopolista discriminar preços. Perry (1992) afirma que as conclusões obtidas utilizando firmas monopolistas também se aplicam a oligopólios.

No primeiro caso, a integração para frente pode aumentar os lucros se as proporções dos insumos não são fixas na função de produção e se o aumento de lucro é maior do que os custos de aquisição. Em uma indústria na qual a proporção de uso dos insumos na função de produção é variável, o preço do insumo de uma indústria monopolista força o fabricante a substitui-lo (tanto quanto possível) por outro proveniente de uma indústria competitiva, resultando em perda de eficiência no processo produtivo. Esta perda pode ser revertida quando a indústria integra, em seu processo produtivo, a produção desse insumo, aumentando sua utilização, devido à redução de seu custo e, por conseqüência, melhorando o nível de eficiência (Perry, 1992).

No segundo caso, ainda segundo o autor, a integração pode garantir a efetividade desta discriminação de preço. A integração busca eliminar arbitragem entre os agentes do mercado de maior elasticidade-demanda, no qual o preço é menor, e os de menor elasticidade-demana, que possui preços maiores. Isto é, evitar a revenda do produto daqueles que pagam menores preços para aqueles que pagam mais (Carlton \& Perloff, 1994).

A integração, ainda, pode servir para a eliminação de poder de mercado de um monopsônio. Uma firma que adquire um insumo importante e paga o preço de monopólio deve determinar a eficácia, em termos de redução de custos, em se integrar para trás e produzir esse insumo. Caso a firma cogite em adquirir a empresa monopolista, deve-se observar que o lucro combinado das duas firmas só aumenta se a proporção de insumos, utilizados no processo produtivo, não for fixa (Perry, 1992).

A integração para trás, segundo Perry (1992), pode ainda ter a finalidade de criar barreiras de entrada. Um entrante potencial, que antes poderia participar de apenas um estágio, com a integração, é forçado a considerar a entrada nos dois estágios de produção. Cria, também, barreira para a integração vertical de outras empresas de 
estágios de produção vizinhos.

O autor aponta o aumento de custo de empresas concorrentes como outro incentivo à integração. Este aumento pode dar-se quando a firma adquire o monopólio deste insumo, ou quando possui parte substancial dele, tornando o mercado restrito. Caso as concorrentes queiram aumentar a produção, causará a elevação do preço deste insumo devido à pequena oferta e, por conseqüência, ao aumento em seus custos.

Perry (1992) cita, como outra determinante para a integração vertical, a economia tecnológica. Em alguns casos, pode-se reduzir custos eliminando passagens de produção ou necessidade de insumos com a integração, obtendo a mesma produção. $\mathrm{O}$ autor menciona o caso da produção de chapas de metal, no qual a integração elimina a necessidade de reaquecimento do ferro. Apesar das fronteiras dos estágios de produção serem bem definidas, e ser possível a comercialização por contratos ou mercado entre elas, a integração reduz os custos eliminado um passo no processo de produção.

As restrições verticais são outro aspecto importante sobre as relações verticais. Elas são caracterizadas por contratos, geralmente de longo prazo, entre empresas que especificam preços, qualidade, quantidade ou outras formas de comportamento. Em alguns casos, as firmas preferem utilizar-se de contratos ao invés de integrar, pois os custos de monitoramento internos são maiores do que os custos de usar firmas independentes (Carlton \& Perloff, 1994).

A relação entre firmas é conhecida como relação agente-principal, na qual o "principal" contrata o "agente" para realizar uma ação. O primeiro estabelece regras de pagamento, porém não tem o controle total sobre as ações do segundo e observa somente o resultado da atividade. As ações do "agente" influenciam, além dos seus retornos, também as do "principal".

A indústria pode utilizar diversas combinações de restrições verticais para 
reduzir problemas como markup dupla de monopólio, "carona"11 etc., com relação à distribuição de seus produtos. Essas restrições limitam a rivalidade, mas, ao mesmo tempo, encorajam o aumento de esforços para a venda de produtos por parte da distribuição (Carlton \& Perloff, 1994, p.533).

Para Carlton \& Perloff (1994), os efeitos contraditórios da restrição, redução da rivalidade e aumento do esforço de vendas, não permitem aos economistas saberem de antemão se os contratos são desejáveis ou não. Quando as restrições verticais, por exemplo, beneficiam tantos às empresas quanto aos consumidores, o contrato é desejável. Isto ocorre quando as empresas utilizam estes contratos para a redução dos custos de distribuição dos seus produtos. Neste caso, os consumidores são beneficiados com a diminuição de preço e/ou melhora nos serviços e as empresas, pelo aumento das vendas.

A restrição vertical pode ter resultados ambíguos quando, por exemplo, o aumento na quantidade de serviços que acompanham um produto, acarreta aumento de preços. Alguns consumidores podem ser beneficiados com a melhora nos serviços e não se importam com o aumento de preços, porém, outros podem não desejar esse serviço e se sentem prejudicados com o aumento de preços.

Outro resultado ambíguo ocorre quando a indústria utiliza a restrição vertical para efetivar a discriminação de preços. Como sucede na integração vertical, quando uma firma vende o mesmo produto a um preço de atacado maior em um mercado om elasticidade-demanda menor e preço menor em um mercado com elasticidade-demanda maior, o distribuidor do segundo mercado pode revender o produto para o primeiro. Para evitar isso, a indústria proíbe, no contrato, a revenda em outros mercados, e em troca o revendedor possui exclusividade no mercado em que atua. Porém, segundo Carlton \& Perloff (1994), a discriminação imperfeita de preços tem um efeito ambíguo sobre o

\footnotetext{
${ }^{11}$ De forma genérica, o "carona" pode ser definido como aquele que contribui menos para a obtenção de um bem público não exclusivo do que o verdadeiro valor marginal que ele atribui a esse bem (Sandler, 1995, p.17).
} 
bem-estar, podendo melhora-lo ou piorá-lo em relação ao preço de monopólio simples.

Com relação aos efeitos indesejáveis das restrições verticais, os autores apontam a possibilidade do uso dos contratos para propósitos anticompetitivos, como formação de cartéis ou prevenção de entrada de novas firmas. Os distribuidores, por exemplo, através de contratos de exclusividade para um mercado, podem exercer poder de monopólio, encarecendo os produtos e diminuindo o bem estar dos consumidores. As restrições, através de contratos de exclusividade, reduzem os canais de distribuição, dificultando ou até impedindo a entrada de novas empresas por não terem meios de comercializar seus produtos (Carlton \& Perloff, 1994).

\subsection{Ação coletiva}

Este item tem como objetivo fazer uma breve apresentação dos principais conceitos das ações coletivas que possibilitem compreender a formação das associações por parte dos pequenos supermercados, suas vantagens e desafios, sem o intuito de exaurir a discussão sobre o assunto.

Segundo Nassar (2001), a Lógica da Ação Coletiva tem como origem a Teoria dos Grupos. Esta última afirma que o interesse comum é uma condição suficiente para a formação de grupos. Pompeu (1997) afirma que Commons (1950) ${ }^{12}$ foi um dos primeiros autores a escrever sobre ações coletivas. Porém, Mancur Olson ${ }^{13}$, em 1965, estabelece pela primeira vez uma explicação econômica para a formação de grupos, investigando as razões da preferência pela atuação conjunta dos indivíduos, ao invés da ação individual, e contribui ao discutir a presença do "carona" como agente complicador da formação de grupos e que estes últimos provêm bens coletivos (Nassar, 2001). Apesar das idéias de Olson terem sido aperfeiçoadas nos últimos anos, elas são, ainda, básicas para a compreensão da ação coletiva. Contudo, algumas das criticas recentes são

\footnotetext{
${ }^{12}$ COMMONS, J.R. Economics of Collective Action. New York: MacMillan, 1950.

${ }^{13}$ OLSON, M. The logic of collecti ve action: public goods and the Theory of Groups. Cambridge: Harvard University Press, 1965.
} 
apresentadas resumidamente no item 2.4.2.2.

Para Sandler (1995, p.1), o livro de Olson (1999) influenciou tanto o pensamento na área de economia, com estudos sobre sindicatos de trabalhadores, bens públicos, crescimento econômico, macroeconomia, questões ambientais etc., quanto em outras áreas, como sociologia, antropologia e ciência política, alternado a forma de pensar sobre a ação coletiva. Introduziu a possibilidade do resultado de uma ação coletiva não trazer benefício ao grupo por ser uma busca conjunta por benefícios individuais.

O trabalho possui, também, os elementos primordiais da Teoria dos Clubes, formulada por James Buchanan $(1965)^{14}$. Esta teoria discute grupos voluntários que se beneficiam da divisão de custo de produção, características dos membros e/ou produção de bens exclusivos. De forma geral, a Teoria dos Clubes afirma que, na presença de mecanismos de exclusão (pedágios, monitoramento eletrônico etc.), a provisão de bens de clube pode eliminar a necessidade de intervenção do Estado. Contribuiu, ainda, para a discussão de muitos dos problemas de pressão enfrentados pela humanidade (como preservação do meio ambiente) que são de natureza da ação coletiva (Sandler, 1995).

\subsubsection{Conceitos básicos da Lógica da Ação Coletiva e incentivos à formação de organizações}

Hardin (1994) $)^{15}$, citado por Nassar (2001), e Sandler (1995, p.xvii) definem ação coletiva. $\mathrm{O}$ primeiro, como relações sociais que visam alcançar um objetivo em comum e que não podem ser realizadas individualmente, requerendo ações conjuntas. O segundo acrescenta a necessidade de coordenação de esforços, pois as ações são interdependentes e o resultado para uma pessoa depende da ação de outras. Desta forma, a ação coletiva surge da constatação de que, por possuírem necessidades comuns que só podem ser atendidas por meio de ações conjuntas, os indivíduos agem de forma conjunta fora do

\footnotetext{
${ }^{14}$ BUCHANAN, J. An economic Theory of Clubs. Economica, v.32, p.1-14, Feb. 1965.

${ }^{15}$ HARDIN, R. One for all: the logic of group conflict. Princeton: Princeton Un iversity Press, 1994.
} 
sistema hierárquico (Nassar, 2001).

Portanto, a ação coletiva pressupõe a existência de alguma forma de organização, cujo conceito engloba um grande leque de entidades, como família, firmas, governos, associações de interesse privado, entre outros. Segundo Olson (1999), um grupo de indivíduos possui incentivo para constituir uma organização quando compartilha um interesse ou objetivo em comum e julga que a ação individual independente não tem condições de promovê-lo adequadamente. Assim, a "função e a característica básica [da organização] é sua faculdade de promover interesses comuns de grupos de indivíduos" (Olson, 1999, p.19) de maneira coordenada, mesmo que seus membros tenham outros interesses conflitantes. O autor ressalta que focaliza em seu estudo o tipo de organização que supostamente promove os interesses de seus membros.

Segundo Saes (2000), as organizações são possíveis e necessárias, pois os mercados falham na alocação de recursos, devido à existência de bens públicos, externalidades, incertezas e racionalidade limitada dos agentes. Desta forma, em concordância com Olson (1999), os agentes unem-se em busca de alcançar interesses comuns, objetivando ao mesmo tempo atender aos seus interesses privados. Em termos gerais, "a razão de ser das organizações pode ser descrita como a maximização de determinadas funções objetivo, dentre os conjuntos de oportunidades permitidas pela estrutura institucional da sociedade" (Saes, 2000, p.169). O resultado das ações de uma organização deve ser maior do que a soma dos resultados individuais, para incentivar sua formação.

Nassar (2001) acrescenta que as organizações não devem cumprir as mesmas funções dos agentes que a formam, para não serem concorrentes entre si. Além disso, os benefícios obtidos com a organização devem ser superiores aos custos de manutenção e de oportunidade, para que a contribuição espontânea seja um ato racional.

A formação de organizações é motivada, segundo Saes (2000, p.170), por vários fatores, como prover bens ou serviços públicos (ou coletivos) e de clube, minimizar custos de transação, alterar as "regras do jogo" para o benefício próprio (lobby), 
modificar alocações alcançadas espontaneamente pelo mercado, proporcionar ganhos de escala e solucionar conflitos.

Olson (1999, p.26) define benefício público, coletivo ou comum, como "qualquer benefício, que se consumido por qualquer pessoa $X_{i}$ em um grupo $X_{1}, \ldots, X_{i}, \ldots, X_{n}$, não pode viavelmente ser negado a outro membro deste grupo". Porém, estes benefícios podem possuir algumas características distintas, tendo subclassificações. Existem os benefícios públicos puros e impuros, que Olson (1999) denomina respectivamente de bens coletivos "inclusivos" e "exclusivos".

Bens ou serviços públicos puros são caracterizados por serem não-exclusivos (uma vez produzidos não se pode excluir ninguém de seu uso) e não-rivais (o uso por um indivíduo não reduz a quantidade disponível para os demais). Um exemplo clássico de um serviço público é o farol de sinalização marítimo. Uma vez em funcionamento, não se poder impedir o uso por embarcações que não contribuíram para a construção e manutenção do farol e sua utilização por um navio não reduz a sua disponibilidade para os demais (Saes, 2000).

Para os bens e serviços públicos, o mercado competitivo não fornece as quantidades desejadas pela sociedade, pois os produtores individuais não conseguiriam recuperar os custos de produção (Saes, 2000). Isto ocorre pois não é possível precificar algo que não se pode excluir alguém de usá-lo e que pode ser consumido indefinidamente. Nesse caso, os indivíduos não têm incentivos para pagar pela utilização desse bem ou serviço, uma vez que esperam que outros o façam e, portanto, possam beneficiar-se gratuitamente. A atuação das organizações, como o Estado, pode, neste caso, levar a resultados mais eficientes do que as ações individuais.

Em contraste aos bens públicos, existem os bens privados em que a posse dos benefícios é totalmente exclusiva e rival entre os usuários. São exemplos, comida, roupa, papel etc. Entre os bens públicos e privados, há os bens públicos impuros. Estes são parcialmente rivais e/ou exclusivos. Os bens de clube são uma forma de bens públicos impuros, no qual os benefícios são exclusivos e parcialmente não-rivais (Sandler, 1995). 
Os benefícios coletivos "exclusivos"16 de Olson (1999) também se enquadram entre os benefícios públicos impuros, pois, para o autor, são aqueles que a exclusão não é viável dentro de um determinado grupo e são rivais.

Os bens de clube, segundo Saes (2000), ocorrem quando uma minoria tem interesses comuns, que, por não serem de desejo da maioria, não são providos na quantidade desejada pelo Estado democrático (pautado pela regra da maioria). Esses indivíduos podem formar uma organização visando a obtenção de tais bens coletivos, porém, arcam com os custos de produção e buscam excluir do consumo aqueles que não colaboram.

A autora afirma ainda que custos de transação podem incentivar a formação de organizações, caso haja formas alternativas de governar tais transações. Dependendo das dimensões da transação (especificidade de ativos, frequiência da transação e incerteza, visto anteriormente), a coordenação de produção ou aquisição de bens ou serviços necessários para o processo produtivo, por uma organização, pode reduzir esses custos em relação aos de aquisição individual no mercado.

A organização de grupos que visam alterar as "regras do jogo" (lobby), sejam eles informais ou formais, objetivando o benefício próprio ou da sociedade, tem sido uma das mais importantes razões para formação de uma organização de interesses privado. Essas organizações podem ter como finalidade a obtenção de subsídios para um setor, controle de entrada de novas firmas, controle de preços, entre outros (Saes, 2000, p.173).

Saes (2000) afirma que, quando o mercado não sinaliza corretamente o valor de

\footnotetext{
${ }^{16}$ Deve-se observar que o termo "exclusivo" utilizados por Olson (1999) para definir benefícios coletivos "exclusivos" difere do significado utilizado pelos demais autores. Enquanto para o autor o significado de "exclusivo" denota o anseio de cada membros do grupo de excluir os demais participantes do grupo devido à característica de rivalidade do benefício (o que não é possível, pois o benefício não seria fornecido sem a presença de todos), para os demais, o significado de exclusivo é a possibilidade de impedir a utilização do benefício para certos indivíduos. Portanto, os benefícios coletivos "exclusivos" de Olson são os benefícios coletivos impuros, que são rivais e não-exclusivos (pelo menos dentro do grupo).
} 
ações individuais ou coletivas, podem surgir organizações visando modificar as alocações resultantes do mecanismo de mercado. Segundo a autora, existem várias ações que influenciam o bem-estar das pessoas, mas que não são precificados, como criação de um fundo para campanhas de conscientização da população a respeito de transmissão de doenças.

Outro incentivo para formação de organizações é a economia de escala. A redução do custo unitário de produção ou comercialização, por exemplo, pode tornar viável e incentivar a constituição de uma organização. Cooperativas de comercialização são bons exemplos. Elas consolidam a produção pulverizada, e com isso possibilitam aumento do volume comercializado por transação, reduzindo a quantidade de negociações e seus custos inerentes (Saes, 2000).

Saes (2000) aponta, ainda, a possibilidade de soluções de conflitos por árbitros privados como incentivo à formação de organização. Os custos da utilização das ações judiciais (taxas e honorários), os esforços para transmitir as informações técnicas relevantes e a incerteza da sentença podem ser reduzidos, caso for utilizado um árbitro privado, pois este pode ser um especialista da área em questão.

Olson (1999) discute outros incentivos que não os puramente econômicos para a ação coletiva. Segundo o autor (p.72), as pessoas podem ser incentivadas pelo desejo de prestígio, amizade, respeito e outros objetivos de fundo psicológico e social. Em grupos pequenos a "pressão social" pode levar os membros a participarem no cumprimento das metas da ação coletiva, sob pena de exclusão do clube social. Essa "pressão" pode ser eficiente, dado pela valorização das pessoas pelo status social, prestígio pessoal e autoestima. Os incentivos sociais são benefícios individuais e não coletivos, desta forma podem ser classificados como incentivos seletivos (conceito discutido mais adiante), que são utilizados para mobilizar grupos "latentes". Olson (1999, p.73) afirma que "os incentivos sociais devem ser analisados de maneira muito semelhante aos incentivos 
monetários".

Porém a ação coletiva pode ser limitada pela figura do "carona". Sandler (1995) afirma que apesar do termo "carona" (free-rider) não ser citado por Olson, seu conceito está associado ao trabalho do autor quando este afirma que um grupo pequeno não tem incentivo para gastar em bens coletivos se um grupo maior já o fez. Segundo Nassar (2001), como cada indivíduo associa um valor diferente a um bem coletivo, uns estão dispostos a contribuir mais para obtenção deste bem do que outros. Os indivíduos que possuem menor interesse não têm incentivos para contribuir, pois um subgrupo com maior interesse irá faze-lo de qualquer maneira.

Segundo Sandler (1995), a figura do "carona" em ações coletivas resulta em quantidade subótimas na provisão de bens públicos. Está relacionada, também, a deficiência do indivíduo em revelar sua verdadeira preferência por bens públicos através das contribuições, além de indicar a tendência para a queda da contribuição marginal e média com o aumento do grupo. Para o autor, a "exploração do grande pelo pequeno", como Olson (1999) apresenta a figura do "carona", ocorre apenas com os bens públicos puros.

\subsubsection{A lógica olsoniana}

\subsubsection{Tipos de organização}

Olson (1999) divide as organizações quanto à característica dos benefícios, tamanho e grau de incentivo à ação. Saes (2000) acrescenta, ainda, outras formas de classificação segundo formas de vinculação e monitoramento.

O vínculo de um indivíduo a um grupo, segundo Saes (2000), pode ser compulsório ou voluntário. O primeiro ocorre quando se pertence a uma organização independente a sua vontade, como fazer parte de uma família, nação, ser recruta do exército etc. O vínculo voluntário ocorre quando os indivíduos trocam direitos de forma espontânea, formando firma, clubes etc. As organizações de adesão voluntária são 
conhecidas também como associações.

A cooperação de um indivíduo em uma organização pode ser induzida ou espontânea. Segundo Williamson $(1995)^{17}$, citado por Saes (2000), a cooperação induzida ocorre quando ela é coordenada, intencional e possui separação entre o incentivo indutor e o resultado da ação. Neste caso, há necessidade de mecanismos de incentivo ou que obriguem os agentes a atuarem conjuntamente. A cooperação espontânea, em oposição, ocorre sem um objetivo comum ou coordenação consciente, como no primeiro caso.

Olson (1999) enfatiza a diferença entre grupos grandes e pequenos. Para o autor, a formação de grupos, segundo a teoria tradicional, presume que a participação nas associações voluntárias é universal. Tanto os pequenos, quanto os grandes grupos, segundo a teoria, atraem membros pela mesma razão, ou seja, pela necessidade ou objetivo em comum. Essa teoria distingue grupos grandes ou pequenos apenas na escala das funções que exercem e não no desempenho de suas atuações ou capacidade de atrair membros.

Porém, para o autor, os grupos pequenos e grandes atuam com bases em princípios distintos. Para compreender as diferenças entre os grupos, Olson (1999, p.34 5) apresenta algumas proposições.

- cada indivíduo pode conferir um valor diferente aos benefícios públicos desejados pelo grupo, portanto, os membros não possuem interesse em comum no que tange a pagar o custo desse benefício - cada membro gostaria que os outros pagassem, deixando-o livre dos encargos e recebendo apenas os benefícios da ação;

- a função do custo total e os custos iniciais e fixos (que são significativos) para provisão dos benefícios coletivos são ascendentes. Ou seja, o custo é uma função da

17 WILLIAMSON, O. Organization Theory. from Chester Barnard to present and beyond. London: Oxford University Press, 1995. 
taxa ou nível de obtenção do benefício coletivo;

- a curva da função do custo médio tem a forma convencional de U;

- a fração que cada membro recebe do ganho total depende do número de integrantes do grupo e do quanto o indivíduo é favorecido em relação aos outros membros do grupo;

- a vantagem individual dos membros corresponde a sua fração do ganho total menos o custo para obter o benefício;

- o ganho total do grupo depende da taxa ou nível de obtenção do benefício coletivo e do tamanho do grupo;

- o tamanho do grupo depende do número de indivíduos e do valor que uma unidade de benefício coletivo tem para cada indivíduo.

A partir destas suposições, Olson (1999, p.60) apresenta três fatores independentes e cumulativos, que podem impedir que grandes grupos promovam seus interesses. Segundo o autor, quanto maior for o grupo, menor é a fração que cada membro, que atue pelos interesses do grupo, recebe, ou seja, menor a recompensa pela ação coletiva. Desta forma, os esforços para alcançar os objetivos são menores, ou até inexistentes, resultando em um distanciamento do ponto ótimo de obtenção do benefício coletivo. O segundo fator é que quanto maior o grupo, menor é a probabilidade de um subgrupo, ou um indivíduo, atue para obtenção do benefício, pois menor o seu benefício para compensar os custos (que são proporcionais ao tamanho do grupo). Finalmente, o terceiro fator relaciona o aumento do custo da organização com o crescimento do número de membros, o que eleva a barreira a ser transposta antes que alguma quantidade do benefício possa ser obtida.

Em vista disso, o autor conclui que quanto maiores os grupos mais distantes do ponto ótimo do provimento do benefício coletivo se encontram e que, quando são muito grandes, não conseguem prover quantidades mínimas desses benefícios sem coerção ou incentivos independentes e externos. Os Estados, por exemplo, são organizações cujos membros são os cidadãos e que sofrem desse problema. Por serem grupos muito grandes e devido à natureza de seus benefícios, não sobrevivem com contribuições voluntárias, e 
por isso devem recorrer aos impostos.

Para o autor, além disso, um indivíduo racional e voltado ao auto-interesse não tem incentivo para contribuir a uma grande organização, pois percebe que a perda de um contribuinte não causa danos à associação, e acredita que sua saída não será acompanhada pelos demais. Adicionalmente pode continuar a usufruir o benefício, devido à característica do benefício coletivo. Portanto, Olson (1999) não acredita na eficácia dos grandes grupos.

Já grupos pequenos podem, segundo o autor, fornecer benefícios coletivos sem a necessidade de coerção, ou outra forma de imposição que não sejam os benefícios em si. Isto ocorre quando o ganho total é muito superior ao custo total, e a fração do benefício total obtida por uma pessoa é suficiente para incentiva-la a arcar com todo o custo para sua obtenção. Ou seja, há membros que, mesmo arcando com os custos sozinhos, obtêm vantagens se o benefício for provido. Este fato ocorre principalmente em grupos pequenos, pois cada membro fica com uma porção substancial dos benefícios, simplesmente porque o grupo tem poucos membros.

O autor afirma, ainda, que a probabilidade de ocorrer ação voluntária, em busca de um benefício coletivo, será maior se o grupo pequeno for caracterizado por um grau de desigualdade considerável, isto é, em grupos com membros de "tamanhos" ou graus de interesse pelo benefício diferentes. Isto ocorre porque as diferenças fazem com que os benefícios sejam divididos desigualmente, ou para alguns os benefícios tenham maior valor, e com isso aumenta a possibilidade de pelo menos um membro ser incentivado a custear a provisão do benefício.

Olson (1999) acrescenta que, dependendo se o grupo está ou não inserido no mercado, os tipos de benefícios coletivos podem ser "exclusivos" ou "inclusivos", resultando em um fluxo distinto de entrada e saída dos membros.

Os benefícios coletivos "exclusivos", segundo a definição do autor, são aqueles que não têm nenhum tipo de partilhabilidade, ou seja, s̃o rivais (o uso por um membro 
reduz a disponibilidade para os demais, por terem uma quantidade fixa, limitando o ganho). Por esta razão, apesar da exclusão de membros dentro de um determinado grupo não ser viável, os indivíduos do grupo desejam que os outros possam ser excluídos dele para aumentar os seus ganhos. São benefícios gerados por grupos que estão inseridos no mercado.

Já os benefícios coletivos "inclusivos" caracterizam-se por serem não-rivais, ou seja, possuem certa partilhabilidade; por este motivo, membros adicionais podem desfrutar do benefício obtido com pouca ou nenhuma redução do usufruto dos membros antigos. Além disso, esses benefícios são de tal natureza que os ganhos, que os nãocooperados recebem, não ocasionam perdas correspondentes àqueles que cooperaram.

Grupos "exclusivos" e "inclusivos" possuem, portanto, atitudes ambivalentes com relação aos novos membros, correspondente mais aos objetivos envolvidos do que às características de seus participantes. Em grupos "exclusivos", apesar d seus membros serem rivais, por exemplo, em um mercado, e, portanto, desejam a eliminação dos seus concorrentes, eles têm certos objetivos em comum. Na formação de um conluio, visando ao aumento de preço através da restrição de produção, por exemplo, há a necessidade de participação de todos que atuam no mercado em questão, pois se apenas um não o fizer, os membros do cartel não têm ganhos e o não-participante do grupo fica com todo o ganho.

Desta forma, uma das características dos grupos exclusivos é o "tudo ou nada", ou todos participam ou não há a formação do grupo. Tal fato aumenta o poder de barganha daquele que se recuse a entrar no acordo, podendo requerer para si a maior parte dos ganhos da ação coletiva. Neste caso, ele pode ganhar tudo numa boa barganha, ou perder tudo com uma ruim, resultando ou não na não formação do grupo.

Outra característica dos grupos "exclusivos" é a sensibilidade às reações de ações dos seus membros. A empresa que melhor prever as reações das outras tem vantagem na barganha. Segundo Olson (1999, p.55), "tanto o desejo de limitar o tamanho do grupo quanto a usual necessidade de cem por cento de participação em qualquer tipo de 
conluio aumentam a intensidade e complexidade das reações oligopolistas".

Em grupos "inclusivos", ou fora do contexto de mercado, há um esforço em inserir todos aqueles que podem colaborar para a obtenção do "benefício coletivo inclusivo", apesar de não ser essencial à participação de cada indivíduo do grupo na organização ou acordo. Isto ocorre porque normalmente os participantes não têm reduzido seus benefícios devido aos não-participantes ou "caronas". Entretanto, para Olson (1999), quando esse benefício não é um benefício público puro, os membros participantes aceitam novos membros apenas se pagarem uma taxa contributiva proporcional ao valor da redução do consumo dos antigos membros. Enquanto esta taxa for menor do que os benefícios obtidos pela ação, vale a pena a entrada de novos membros e o grupo permanece "inclusivo".

Olson (1999) apresenta ainda três classificações para os grupos "inclusivos": os grupos "privilegiados", "intermediários" e "latentes". O primeiro ocorre quando um indivíduo tem incentivo suficiente para prover o benefício coletivo, ou seja, o benefício individual excede os custos totais para sua obtenção. Neste caso, pressupõe-se que a ação será realizada sem a necessidade de uma organização coletiva ou qualquer tipo de coordenação.

Os grupos "privilegiados" possuem baixos custos de negociação, pois a heterogeneidade de interesse de seus membros tende ser menor do que de grupos "latentes". Estes grupos têm, ainda, custos de comunicação pequenos e geralmente adotam ações que beneficiam todos os participantes (conhecidas como ações tipo I) ou que beneficiam parte do grupo, sem prejuízo dos demais (ações tipo II) ${ }^{18}$. Essas características inibem seu desmembramento, que ocorre apenas se uma organização mais eficiente a substitui. Outra vantagem em serem um grupo pequeno e homogêneo, em relação aos grandes grupos, é possuírem um corpo administrativo enxuto, o que reduz os

\footnotetext{
${ }^{18}$ Existem, ainda, as ações tipo III que correspondem àquelas que beneficiam parte do grupo em prejuízo dos demais membros. Neste caso há necessidade de mecanismos de compensação entre os participantes para que a ação ocorra.
} 
problemas entre os membros e a gerência (Nassar, 2001).

Porém, Olson (1999) levanta a possibilidade da ação desses grupos não se efetivar, caso ocorra uma barganha malsucedida, ou seja, cada indivíduo espera que o outro tenha a iniciativa de prover o benefício.

No segundo grupo, "intermediário", a fração de cada membro do benefício não é suficiente para incentivar uma ação individual, porém o grupo não é tão grande a ponto de um membro não perceber se o outro está ou não colaborando, isto é, há um baixo custo de monitorar a contribuição individual. Neste grupo, existe a necessidade de alguma coordenação ou organização grupal, para obter o benefício.

Os grupos "latentes" ocorrem em grandes organizações que têm potencial para a ação, mas os indivíduos não têm incentivos para agirem. Isto se sucede pois a contribuição ou não de um membro não tem impacto significativo sobre o bem-estar dos demais. Portanto, o grupo não tem razão para reagir à ação de seus membros e não há monitoramento dos esforços de cada membro. Desta forma, cada indivíduo espera a ação venha dos demais, buscando agir como "carona", e o benefício não é provido.

Para um grupo "latente" tornar-se uma organização efetiva, necessita-se de um sistema de monitoramento e de incentivo seletivo. O monitoramento tem o objetivo de separar os membros ativos dos "caronas" e viabilizar os incentivos seletivos. Estes incentivos podem ser positivos ou negativos e tratam de forma diferenciada os membros que colaboram dos que não colaboram ou não fazem parte do grupo. Os estímulos positivos são benefícios privados oferecidos somente aos colaboradores. Os estímulos negativos podem ser alguma punição àqueles que não contribuírem com a parte dos custos da ação coletiva que lhes cabem.

Olson (1999) afirma que grandes grupos, como estruturas federais, podem promover a ação coletiva, também, através da formação de pequenos subgrupos. Neste caso, segundo Sandler (1995), os custos de transação e os benefícios coletivos são relevantes na configuração da estrutura do grupo. Deve-se analisar, portanto, a eficiência 
de estruturas de organização alternativas para identificar aquela com melhores aspectos de benefícios e de transações. Porém, mesmo assim, os benefícios podem ser perdidos devido à interação limitada de toda a ação coletiva (relações entre os subgrupos), necessitando de um exame minucioso antes da estrutura ser montada (Sandler, 1995).

Olson (1999, p.64) conclui que a possibilidade da busca racional e voluntária de um interesse individual gerar ações coletivas depende principalmente do tamanho do grupo. Os grupos pequenos promovem seus interesses comuns melhor do que os grandes. Isto ocorre porque os grupos pequenos não são somente quantitativamente diferentes dos grandes, mas, também, qualitativamente e, portanto, a existência de grandes grupos não pode ser explicada pelos mesmos fatores dos pequenos.

\subsubsection{Considerações sobre a lógica olsoniana}

Algumas das idéias apresentadas por Olson, entretanto, foram revistas em estudos mais recentes. Para Nassar (2001, p.42), por exemplo, alguns aspectos são negligenciados no trabalho de Olson (1999) e que podem influenciar a formação de organizações coletivas. São eles:

- papel da liderança como fator aglutinador;

- status conferidos àqueles integrantes do grupo;

- estratégia para minimização dos custos de negociação e comunicação;

- racionalidade limitada e oportunismo;

- relações de confiança promovendo ações grupais.

Entretanto, Olson, posteriormente à primeira edição de seu livro "A lógica da ação coletiva" de 1965, admite a importância de um empreendedor na formação de grupos, denominando-o de "empreendedor político". Segundo o autor, devido aos custos e ao tempo gasto em negociações, um grupo, mesmo que pequeno, não consegue o fornecimento na quantidade ótima de um benefício coletivo. Isso possibilita que um líder ou empreendedor, ao economizar tempo de negociação, por exemplo, consiga um ajuste melhor do que em um grupo sem uma liderança ou mediação organizacional. Um 
empreendedor deve inovar na área dos incentivos seletivos para conseguir realizar ações coletivas em grupos grandes ou "latentes" e, também, ser um barganhador, por existir diversos subgrupos em um grupo grande ou por este pertencer a um grupo ainda maior (Olson, 1999).

Olson (1999) afirma que o empreendedor pode ser incentivado a agir quando sua ação traz ganhos tanto ao grupo quanto a si mesmo. $\mathrm{O}$ autor acrescenta que o desejo que algumas pessoas têm em serem líderes, políticos ou fomentadores, também é incentivo à ação para certos indivíduos. Segundo Nassar (2001, p.42), "um empreendedor político será aquele que vislumbrar ganhos privados na ação coletiva".

A questão do status como motivador à ação coletiva, como apresentado anteriormente, também é citado por Olson (1999). Nas palavras do autor "os incentivos econômicos não são, com certeza, os únicos incentivos possíveis" (p.72). Segundo o autor, a valorização das pessoas pelo status pode incentivar a participação em uma ação coletiva, pois os incentivos pessoais são, de certa forma, seletivos, que, por sua vez, são utilizados para mobilizar grupos "latentes".

Olson (1999, p.58-9) ressalta que, para grupos maiores do que aqueles que possuem uma parcela de membros que obtém um benefício coletivo grande suficiente para provê-lo sozinho, há a necessidade de uma organização, acordo ou coordenação para obtenção de um benefício coletivo. Os custos totais de organização são uma função crescente do número de indivíduos, apesar de haver economia de escala em um processo organizacional. E, portanto, não podem ser negligenciados. Os custos de comunicação entre os membros do grupo, de barganha interna, de criar, de organizar e de manter uma organização formal, são exemplos de custos organizacionais.

Para o autor, quanto maiores forem os custos organizacionais totais necessários para a obtenção de benefícios coletivos, menor a possibilidade que os benefícios sejam providos mesmo que em quantidades mínimas, sem que haja coerção ou incentivos externos independentes. Segundo Nassar (1999), porém, o avanço na tecnologia de informação reduz os custos de formação de grupos. Os custos de obtenção e difusão das 
informações estão diminuindo pelo desenvolvimento da informática e, conseqüientemente, os custos de organização.

Segundo Nassar (2001), Olson (1999) não inclui dois fatores que podem influenciar a ação coletiva por utilizar-se do paradigma neoclássico em sua argumentação: relações de confiança e oportunismo. Como apresentado anteriormente, a racionalidade limitada dos agentes (pressuposto comportamental da Economia dos Custos de Transação), torna os contratos incompletos, o que possibilita eventuais ações oportunistas. Estas ações, por não serem cooperativas, podem limitar a formação de organizações (Nassar, 2001).

Em oposição ao oportunismo, para Nassar (2001), a confiança é uma motivação à ação coletiva por reduzir os custos de negociação e uma facilitação do cumprimento dos acordos ou contratos. A confiança, como já citado, está relacionada, segundo a ECT, com uma das dimensões da transação, a freqüência. Quanto maior a frequiência das transações, mais os agentes se conhecem, reduzindo a assimetria de informações, a incerteza e criando uma reputação. Quando isso ocorre, reduzem-se os custos de negociação.

Nassar (2001) afirma que oportunismo e confiança são vetores opostos na análise de ação coletiva. Além disso, o primeiro é um comportamento individual, e o segundo envolve, no mínimo, a ação de dois agentes. Uma negociação tem maior possibilidade de ocorrer, conclui o autor, se a confiança for superior ao oportunismo.

Outra consequiência da adoção do paradigma neoclássico por Olson (1999), é a suposição de que a informação é perfeita, ou seja, os indivíduos sabem exatamente os custos e benefícios marginais, bem como do valor da contribuição individual. Porém, Moe $(1980)^{19}$, citado por Nassar (2001), propõe a incorporação de informação assimétrica, pois dessa forma os agentes realizam suas escolhas racionais a partir de

19 MOE, T. The organization of interests: incentives and the internal dynamics of political interest groups. Chicago: The University of Chicago Press, 1980. 282p. /Midway reprint/ 
estimativas. A decisão dos agentes pode, portanto, ser diferente da indicada pelo modelo com informação perfeita. Um grupo de interesse de posse de informações detalhadas, por exemplo, pode utilizá-las, através de um jogo de assimetrias, para atrair novos membros contribuintes, que normalmente se comportariam como "caronas" (Nassar, 2001).

A incerteza é outro aspecto que pode influenciar a formação de grupos, não tratada por Olson (1999). Segundo Nassar (2001), a tendência do indivíduo comportar-se como "oportunista" em uma ação coletiva aumenta com o risco. Isso ocorre porque cada indivíduo está sujeito a um risco associado à formação da ação coletiva e os atos dos indivíduos estão relacionados às suas expectativas futuras (Nassar, 2001). Mesmo que as condições ex-ante para a formação de uma organização sejam conhecidas e atendidas, as condições futuras, ex-post, são desconhecidas e, portanto, podem reduzir o incentivo à realização da ação coletiva.

Sandler (1995) divide a lógica de Olson em três temas principais e discute o desenvolvimento da teoria em cada um deles. O primeiro tema relaciona-se à influência do tamanho do grupo na ação coletiva. Para o autor, os trabalhos de McGuire (1974) ${ }^{20} \mathrm{e}$ Chamberlin (1974) $)^{21}$ provam que não existe uma relação inversa entre o tamanho do grupo e o volume de benefício provido pelo grupo, quando os bens são normais. O limite do suprimento dos benefícios é baseado na propensão marginal em gastar em bens coletivos, já que o tamanho do grupo pode aumentar indefinidamente e o crescimento do suprimento é acompanhado por uma diminuição na contribuição média ou por pessoa.

Para Sandler (1995), a relação entre redução da eficiência (subotimidade) do fornecimento de benefícios e o aumento do tamanho do grupo, como afirma Olson (1999), ocorre apenas sob determinadas circunstâncias. Essa relação acontece, por

20 McGUIRE, M.C. Group size, group homogeneity, and the aggregate provision of pure public good under Cournot behavior. Public Choice, n.18, p.107-26, Summer 1974.

21 CHAMBERLIN, J. Provision of Collective Good as a function of group size. American Political Science, n.68, p.707-16, June 1974. 
exemplo, quando o grupo é formado por indivíduos idênticos (possuem as mesmas preferências e dotações), possui um equilíbrio simétrico (indivíduos idênticos que contribuem com a mesma soma) e os bens públicos são perfeitamente substitutos entre os provedores. Portanto, não se pode generalizar uma afirmação em relação à eficiência e o tamanho do grupo, dadas as várias combinações possíveis na estrutura do modelo, como arranjo tecnológico, distribuição de preferências, entre outros.

O segundo tema destacado por Sandler (1995) envolve a composição do grupo em termos de assimetria de preferências e dotações. Segundo o autor, a assimetria do grupo depende da estratégia suposta, da tecnologia e a distribuição de preferências e dotações. A hipótese do Olson (1999) da exploração da minoria pela maioria ocorre, portanto, em apenas certas situações.

O uso de incentivos seletivos e do desenho institucional para promover a ação coletiva, é o terceiro tema apontado por Sandler (1995). Segundo o autor, a provisão de produtos casados, que incluem todos os tipos de incentivos seletivos pelas organizações, motiva a ação coletiva de diversas formas. O fornecimento de benefícios privados, juntamente com benefícios coletivos, é um outro incentivo à formação de grupos, e permite, por exemplo, prevenir problemas de "congestionamento" e pode implicar em estrutura de jogos mais úteis para a ação coletiva.

O desenho institucional permite promover a ação coletiva por modificar a tecnologia de suprimento de bens públicos, por exemplo, e reduzir os custos de transação fixos e variáveis.

Sandler (1995) conclui que, em alguns casos, a ação coletiva pode ocorrer espontaneamente, mas em outros há a necessidade de incentivos. Para o autor (p. 196), alguns aspectos são importantes para o sucesso da ação coletiva, como prover (i) produtos casados privados ou passíveis de exclusão (privatizando alguns dos benefícios da ação coletiva), (ii) uma compensação favorável aos agentes dominantes, (iii) mecanismos de exclusão associado a um sistema de taxas e (iv) interações repetidas entre os participantes para a formação de uma reputação. 


\subsubsection{Teoria dos Clubes}

Um clube pode ser definido como grupo de adesão voluntária em que os membros se beneficiam mutuamente da divisão de custos de produção, de bens de clube e/ou características de seus membros. Os principais aspectos do clube são; (i) a associação é voluntária (os indivíduos vêem a associação como uma rede de benefícios), (ii) o tamanho do clube é uma escolha endógena e importante, e, portanto, limitado, (iii) é necessária à cobrança de taxas de associação ou de utilização e (iv) são precisos mecanismos de exclusão (Sandler, 1995).

Os bens de clube, como visto anteriormente, são bens públicos impuros, em que há a possibilidade de exclusão. Porém, os custos da exclusão, que visam evitar a presença de "caronas", devem ser inferiores aos benefícios obtidos com a ação coletiva. Juntamente a um arranjo eficiente, o clube é uma alternativa factível ao uso do mercado para obtenção dos bens e serviços necessitados. Entre os bens de clube, pode-se citar as rodovias, museus, policiamento, universidades, etc. (Sandler, 1995).

Os bens públicos impuros, cujos benefícios estão sujeitos à rivalidade, podem ocasionar o efeito de "congestionamento". O "congestionamento" ocorre quando a utilização de um bem de clube por um indivíduo reduz os benefícios ou a qualidade do serviço que permanece aos demais membros, como filas, serviços lentos, tráfego lento, altos índices de acidentes etc. Portanto, depende da medida de utilização, como número de membros, de visitantes etc. Bens públicos puros não possuem o problema de congestionamento por serem não-rivais (Sandler, 1995).

Segundo Sandler (1995, p.64), "os clubes são uma solução institucional para problemas de ações coletivas por internalizar externalidades através de cobrança de taxas". Caso os membros desses clubes identifiquem e excluam os não-membros, então a cobrança de taxas pode internalizar ou cobrar pelas externalidades do congestionamento entre os usuários sem a necessidade da intervenção do Estado. 
Sandler (1995) afirma que foi Buchanan $(1965)^{22}$ quem primeiramente descreveu como clubes voluntários podem prover a si próprios com bens públicos impuros. Porém, os fundamentos da teoria dos clubes podem ser encontrados no trabalho de Olson (1999), quando distingue entre bens coletivos "inclusivos" e "exclusivos". Sandler (1995) afirma que os bens públicos "exclusivos" não podem ser divididos por um novo consumidor sem a redução dos benefícios dos demais. Para estes bens, o tamanho do grupo precisa ser limitado para internalizar os custos de rivalidade. Portanto, os clubes são os grupos "exclusivos" de Olson. Os grupos inclusivos ocorrem, segundo Sandler (1995), quando não há custos de "congestionamento" ou quando os custos de exclusão são proibitivamente altos ou, maiores do que os ganhos de eficiência.

Para o autor, a Teoria do Clube não dá suporte a dois temas da lógica de Olson. No primeiro, o aumento do tamanho do clube não implica necessariamente na queda da provisão de benefícios. Na realidade, segundo a Teoria dos Grupos, as grandes organizações têm maior facilidade em otimizar as relações entre custos de "congestionamento" e divisão dos custos dos benefícios. Isso ocorre porque a participação nos clubes é voluntária e, desta forma, todos os membros devem possuir incentivos para participar do grupo. Os clubes podem, ainda, criar subgrupos para a recepção dos membros potenciais, expandido sua ação. Portanto, se novos membros estão aderindo ao grupo, significa que estão tendo benefícios.

O segundo tema que está em desacordo, são as questões da composição e assimetria dos grupos. Para o autor, a teoria dos clubes considera a heterogeneidade do grupo e que não ocorre a exploração da minoria pela maioria quando são cobradas taxas cada vez que um membro utilizar o clube. Neste caso, a minoria que tem maior interesse, paga a mesma taxa por utilização, porém, desembolsa um total maior, por ter usufruído mais vezes do grupo, eliminando a exploração e a figura do "carona". Dessa forma, o esquema da taxa de utilização do clube internaliza as externalidades do

\footnotetext{
${ }^{22}$ Buchanan, op. cit., p.45
} 
"congestionamento" e não enfatiza o tamanho do grupo e as dotações dos participantes (Sandler, 1995).

Olson (1999), segundo Sandler (1995), apresenta dois meios para superar problemas de ação coletiva: incentivos seletivos e desenho de estruturas institucionais. Os clubes são estruturas institucionais que visam resolver problemas de ação coletiva sem a necessidade de incentivos seletivos, devido à presença de mecanismos de exclusão que permitem a internalização de custos. Portanto, estão de acordo com o proposto por Olson (1999).

Sandler (1995) acrescenta que diversas formas institucionais são utilizadas nos clubes. Estes podem ser geridos por seus membros, por empresa com ou sem fins lucrativos ou providos por um órgão governamental. São exemplos de clubes administrados por membros, as associações profissionais, igrejas, clubes esportivos etc. Salas de cinema, parques de diversão são bens de clube fornecidos por empresas com fins lucrativos. Parques nacionais, rodovias, serviço policial são exemplos de clubes administrados pelo governo. Hospitais, serviços de ambulância, centros educacionais podem ser exemplos de bens de clube providos por firmas sem fins lucrativos.

A teoria dos Clubes pode ser considerado, portanto, um caso especifico de Ação Coletiva, no qual alguns dos seus pressupostos são restringidos, como a possibilidade de exclusão dos benefícios aos não participantes e limitação do tamanho do grupo. Essas restrições permitem resolver alguns problemas das Ações Coletivas, como o do carona.

As associações de supermercados em estudo são clubes. Isto porque, além de serem relações sociais que visam alcançar um objetivo comum e que não podem ser realizadas individualmente, requerendo ações conjuntas e coordenação de esforços - que define ação coletiva - há a possibilidade de exclusão dos benefícios aos não participantes e de limitação do tamanho do grupo - o que caracteriza os clubes. Porém, dentro das associação, existem ações que são não-exclusivas, como será visto mais adiante, e que permitem, dessa forma, a ocorrência do problema do carona, ou ainda, incentiva esse comportamento dependendo da forma da organização. 


\subsection{Organização Industrial, Economia dos Custos de Transação e a Ação Coletiva}

Apesar das diferenças entre as pressuposições da Economia dos Custos de Transação (ECT) - racionalidade limitada, caracterizada pela incerteza e informação imperfeita - e da Organização Industrial (OI) - maximização de lucro que presume racionalidade ilimitada -, existem pontos que se complementam e permitem articular as duas teorias (Farina et al., 1997).

Segundo Farina et al. (1997), a ECT oferece uma teoria da firma que permite explicar as diferentes formas organizacionais presentes no mercado, especialmente com relação à integração vertical, que se relaciona com a estrutura de mercado da OI.

Tanto a ECT quanto a OI, segundo Williamson $(1985)^{23}$, citado por Farina et al. (1997), buscam compreender os motivos da substituição da organização do mercado por outras formas mais complexas de contrato. Entretanto, a primeira, ECT, recorre à busca da eficiência, enquanto a segunda, pelo poder de mercado, para compreender essa substituição.

Para a OI, as empresas buscam o lucro econômico através do exercício do poder de monopólio, pois permite à firma ter controle sobre a oferta e preço de seus produtos. Quanto maior for a pressão competitiva, maior é a busca por eficiência, uma vez que sua posição é contestada pelos concorrentes efetivos ou potenciais. Portanto, a configuração eficiente do mercado, que resulta na minimização de custo, depende da existência de uma forte pressão competitiva. A ECT, entretanto, assume que os mercados são competitivos sem defini-los precisamente (Farina et al., 1997).

Apesar de não estarem explicitados no trabaho de Olson (1999), os custos de transação estão presentes nas ações coletivas. Nassar (2001) afirma que as despesas com

\footnotetext{
23 WILLIAMSON, O. The economic institutions of capitalism firms, markets, relational contracting.
} New York: The Free Press, 1985. 449p. 
congestionamento, comunicação e barganha são custos de transação, que tendem a criar barreiras à formação de associações, e estão relacionados com tamanho do grupo, assimetria interna e nível de desalinhamento de interesse. As associações possuem, ainda, os custos de manutenção da estrutura e de suas atividades. A soma desses custos, segundo Nassar (2001), são os custos de manutenção apontados por Olson. Desta forma, para um indivíduo racional participar de uma ação coletiva, os custos de manutenção, descritos Olson (1999), devem ser menores do que os benefícios obtidos. Neste caso, a ECT está sendo utilizada para analisar as relações internas da associação e que resultam em uma forma organizacional que busca minimizar os seus custos inerentes.

Entretanto, neste trabalho, as associações são vistas como uma alternativa de governança na relação entre a indústria e o varejo. A ECT é utilizada como uma ferramenta para analisar se as associações são uma estrutura de governança viável, ou seja, se há ganho de eficiência por parte dos supermercados independentes. A Economia dos Custos de Transação é interessante tanto para a análise das transações que ocorrem dentro das ações coletivas como na análise das relações de mercado que incentivaram essa ação.

As associações de supermercados em estudo são clubes, pois há possibilidade de exclusão dos benefícios aos não participantes e de limitar o tamanho do grupo. Porém, dentro delas existem ações que são não-exclusivas, como será visto mais adiante, e que permitem a ocorrência do problema do carona, ou ainda, incentiva esse comportamento dependendo da forma da organização.

No presente estudo, a OI é utilizada por tratar das estratégias competitivas das firmas sob condições oligopolistas e seus efeitos sobre o ambiente competitivo. A busca por poder de monopólio e por vantagens competitivas permite mudar as características da estrutura do mercado, que, por sua vez, pode, ainda, alterar as estruturas de governança eficientes. A ECT permite entender quais as novas estruturas de governança podem ser mais eficientes nessa nova estrutura e o porque. 


\section{REVISÃO DE LITERATURA}

Neste capítulo, são apresentados estudos que visam caracterizar a organização do setor supermercadista, bem como trabalhos relacionados à formação de organizações de compras conjuntas, mais especificamente associações de compras de supermercados. $\mathrm{O}$ objetivo deste capítulo é a compreensão do ambiente competitivo em que se inserem os supermercados e suas transformações, que resultam na necessidade da formação de associações pelas redes independentes.

\subsection{Ambiente competitivo do setor de auto-serviço}

O objetivo deste item é introduzir as principais características do ambiente em que os supermercados se inserem e, portanto, as associações em estudo. O ambiente competitivo influência a conduta das firmas. Como a criação de associação pelos supermercados faze parte da conduta das firmas, se faz necessária esta introdução

Connor (1999) afirma que o setor supermercadista desenvolveu, ao longo de sua história nos Estados Unidos, diferentes formatos de varejo, buscando conquistar os diversos segmentos de mercado. Este aumento na diversidade implicou em mudanças no ambiente competitivo e nas estruturas de custos, que, por sua vez, alterou o padrão de competição do setor, fatos que também são observados no Brasil.

\subsubsection{Competição horizontal}

A competição horizontal no setor supermercadista alterou-se, segundo Connor (1999), com o surgimento de diferentes formatos de lojas. O autor afirma que os principais estudos sobre o setor enfocam os fatores ambientais como possíveis causas 
das diferenças nos preços, mantendo os custos constantes. Outros trabalhos estão preocupados em estimar os preços ótimos para o varejo, geralmente para as lojas, ou ainda para categorias de produtos. Estes estudos utilizam como variáveis a renda e a demografia dos consumidores, e a competição considerada ocorre com outros supermercados que comercializam produtos similares (Connor, 1999).

Outros estudos, ainda segundo Connor (1999), preocupam-se com os níveis de preços de uma região geográfica. Neste caso, a principal variável é a intensidade competitiva, estimada pela participação de mercado ou concentração. Fatores demográficos podem ser considerados, mas apenas para medir as diferenças entre as áreas em estudo.

Nessa linha de estudo, Connor (1999) afirma que muitos dos trabalhos sobre o setor concordam com Smith $(1937)^{24}$, que classificou o setor como de competição monopolística, pois os consumidores se defrontam com diferenciações de preços e espaciais. Contudo, outros autores, como Baumol et al. $(1964)^{25}$, Holdren $(1968)^{26}$ e Marion et al. (1979) $)^{27}$, segundo o autor, classificam o setor como essencialmente oligopolista em relação ao comportamento de precificação.

No Brasil, Cyrillo (1987) classificou a estrutura concorrencial do setor como oligopolista. Para a autora, o mercado de varejo de alimentos brasileiro é dominado por grupos de grandes empresas regionalmente estabelecidas, coexistindo com pequenas empresas, tradicionais ou não, que, em termos individuais, participam pouco deste mercado. Outra característica do setor é a busca de diferenciação de determinadas empresas. Essas características - grupo dominante, coexistência com firmas marginais e

\footnotetext{
${ }^{24}$ SMITH, H. Retail distribution. London: Oxford University Press, 1937.

25 BAULMOL, W.J. Oligopoly theory and retail food pricing. Journal of Business, v.37, p.346-369, 1964.

${ }^{26}$ HOLDREN, B.R. The structure of a retail market and the market behavior of retail units. Ames: The Iowa State Press, 1968.

27 MARION, B.W. et al. The food retailing industry: market structure, profits and prices. New York: Praeger, 1979.
} 
busca de diferenciação - indicam tratar-se, segundo Cyrillo (1987), de um mercado de oligopólio diferenciado com franja.

Cyrillo (1987) explica que o oligopólio diferenciado puro é caracterizado pela presença de um certo número de empresas de grande porte, que participam igualmente do mercado, possuem estrutura de custos semelhantes, suas mercadorias são diferenciáveis e reconhecem a interdependência de suas ações. As empresas têm como objetivo crescerem e, para tanto, seguem políticas de produção, de venda e de preço que visam ao aumento ou manutenção da participação no mercado. Assim, as empresas devem considerar, além da conduta das concorrentes estabelecidas, as ações das concorrentes potenciais. Ou seja, a existência e a intensidade das barreiras à entrada e à saída e a dimensão do mercado, influenciam as decisões das empresas.

Considerando a diferenciação subjetiva como a única barreira à entrada, esperase que o preço final praticado pelas firmas já estabelecidas seja superior ao custo médio de longo prazo. Porém, a diferença entre o preço final praticado e o custo médio de longo prazo é o dispêndio com os custos desta diferenciação. A facilidade em implementar a diferenciação de caráter subjetivo através da publicidade torna esta estratégia simples de se imitar. Empresas, que não obtiveram sucesso alcançado pelo grupo dominante, ficam na dependência da política de preços das empresas maiores (Cyrillo, 1987).

As empresas menores, que compõem a franja, abastecem parcelas que não são de interesse do segmento dominante e diminuem o poder de monopólio, na mesma medida em que a velocidade de reação de tais empresas em relação a aumentos de preço é maior do que as dos concorrentes potenciais (Cyrillo, 1987).

Silveira \& Lepsch (1997) afirmam, entretanto, que devido às mudanças que ocorreram após o plano Real (aumento da concorrência através de preço e extrapreço, mudança na ênfase administrativa do financeiro para o operacional, entre outros), o setor caminha para uma direção de menor poder de monopólio. Esta opinião confronta com o crescimento da participação na receita total do setor por parte das grandes cadeias, 
indicando aumento da concentração.

Os efeitos das mudanças no setor, tanto no Brasil como no exterior, geraram uma série de trabalhos, que visam observar as suas consequiências. Dobson \& Waterson (1997), observando o aumento da concentração do mercado varejista inglês, propuseram-se examinar as implicações do poder de barganha entre o varejo e a indústria para os preços finais e para o bem-estar do consumidor. Segundo os autores, as autoridades britânicas não reagiram a esse aumento de concentração, pois pressupunham que era pró-eficiente devido ao aumento do poder de barganha do varejo e à economia de escala e escopo.

Os autores utilizaram para esse estudo um modelo teórico de jogos de dois estágios para caracterizar o comportamento de mercado. $O$ primeiro representa a negociação entre o fornecedor e cada varejistas. No segundo estágio, os varejistas competem entre si simultaneamente e independentemente para ajustar os preços finais visando maximizar os lucros individuais, ou seja, um comportamento Bertrand-Nash.

Esse estudo aponta, entretanto, que a redução nos preços finais ocorre apenas quando o consumidor enxerga o serviço entre os varejos como fortemente substituto. No limite, em que existem apenas dois varejistas iguais e seus serviços são percebidos como perfeitamente substitutos, os níveis de preços finais chegam aos níveis dos custos marginais. A intensa rivalidade no varejo, em um mercado altamente concentrado, impacta não somente no lucro do varejo como também no do fornecedor, pois o primeiro irá exigir melhores condições de compra do segundo.

$\mathrm{Na}$ Figura 5, observam-se as relações encontradas pelos autores. A variável dependente $\mathrm{p}$ representa o nível de preços praticado pelos varejistas, $\gamma$ representa o grau de substitutibilidade entre os varejistas (quanto maior, mais os consumidores percebem as lojas como substitutos) e $\mathrm{N}$ refere-se ao número de varejistas considerado. Quando $\gamma$ é zero, os varejistas atuam como monopolista, por isso não importa o número de firmas, o preço praticado sempre será o mesmo. Conforme o grau de substitutibilidade $(\gamma)$ 
aumenta, o nível de preços reduz. Para graus de $\gamma$ menores, essa redução é maior para mercados com mais firmas, e para $\gamma$ maiores, ocorre o inverso. Por este motivo, que, segundo o estudo, duopólio, em varejo, pode ser socialmente preferível em relação a mercados menos concentrados quando $\gamma$ é próximo ou igual a um (Dobson $\&$ Waterson, 1997).

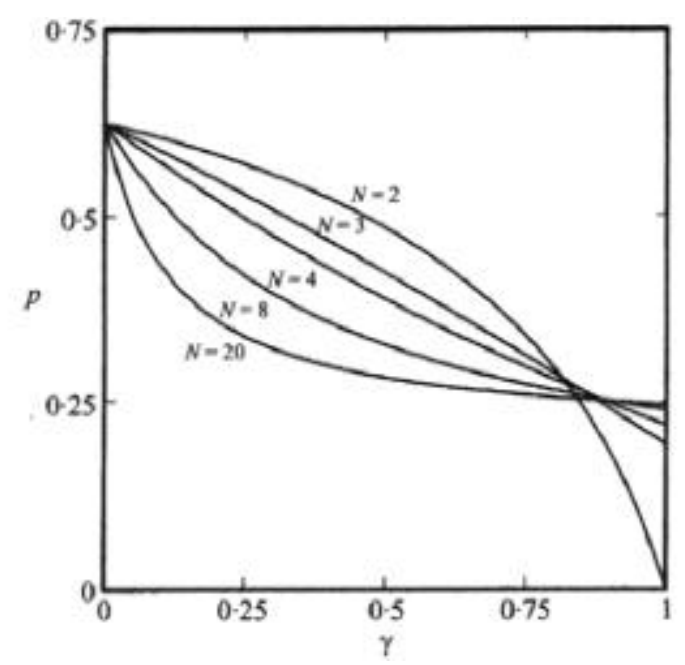

Figura 5 - Preços do varejo em relação ao grau de substitutibilidade e número de varejistas.

Fonte: Dobson \& Waterson (1997, p.425)

Os autores acrescentaram ao estudo os efeitos no bem-estar social. Neste caso, as condições para haver aumento do bem-estar são maiores do que para haver redução dos preços finais, pois inclui a variedade de serviços do varejo (que incluem localização, conveniência, layout da loja, ambientação e serviços de venda). O aumento da substitutibilidade entre o varejo, bem como a redução do número de empresas, causa redução no bem-estar, devido à queda da variedade do serviço. A relação entre número de empresas e bem-estar só se inverte em graus de substitutibilidade próximo a um, ou seja, nos casos nos quais os varejos são fortemente substitutos, a redução no número de firmas pode aumentar o bem-estar do consumidor, como se observa na Figura 6. Desta 
forma, segundo Dobson \& Waterson (1997), o aumento de concentração no varejo pode ser socialmente benéfico se a rivalidade for intensa, mas em graus de substitutibilidade pequenos e medianos, o aumento de concentração resulta em níveis de preços maiores e menor variedade de serviços.

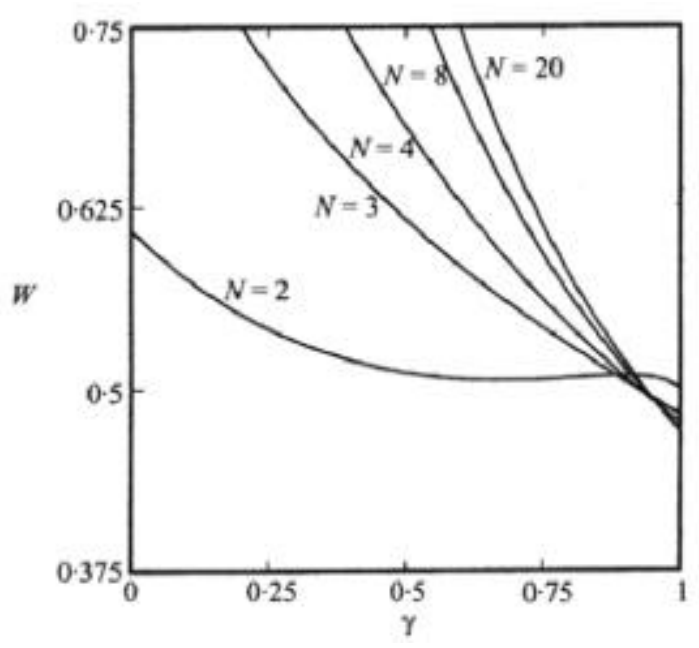

Figura 6 - Níveis de bem-estar social em relação ao grau de substitutibilidade e número de varejistas.

Fonte: Dobson \& Waterson (1997, p.426)

Dobson \& Waterson (1997) concluem afirmando que o aumento de concentração possibilita a ampliação do poder de compra e venda do varejo. Isto pode resultar tanto na queda dos preços e aumento no bem-estar, quanto o inverso. No primeiro caso, com aumento de poder de compra, tem-se o crescimento do poder de barganha, o que pode pressionar a redução dos preços dos intermediários. Porém, com o aumento de poder de venda, o varejo tem a possibilidade de aumentar as margens de venda, elevando os excedentes das firmas (tanto intermediária quanto final). Segundo os autores, se o segundo efeito dominar, o aumento da concentração do varejo pode resultar em aumento de preços intermediários e finais e reduzir o bem-estar do consumidor. Neste caso, o poder da rivalidade para aumentar o bem-estar do consumidor é limitado.

Outros estudos de cunho mais prático relacionam a concentração do mercado 
varejista com índices de preços, que, de certa forma, reforçam os argumentos de Dobson \& Waterson (1997). Marion et al. (1979) $)^{28}$, citado por Connor (1999), em um estudo utilizando dados de varejo de 36 cidades norte-americanas e de uma cesta de 94 produtos, encontrou relação positiva entre o índice de preço e de participação de mercado $\left(\mathrm{C}_{4}\right)$. Lamm $(1988)^{29}$ e Cotteril \& Harper $(1995)^{30}$, também citado pelo autor, encontraram resultados semelhantes em seus estudos, o primeiro utilizando índices de preços publicados de 18 grandes áreas metropolitanas nos Estados Unidos, e o segundo de 34 mercados locais em Arkansas.

Connor (1999) também cita um trabalho realizado por ele e Drescher $(1999)^{31}$, no qual foram utilizados dados de lojas de alimentos de 50 cidades alemãs em 1993. Neste estudo, os autores obtiveram uma relação entre a razão de concentração das cinco maiores empresas $\left(\mathrm{C}_{5}\right)$ e o índice de preços em formato de $\mathrm{U}$. Até $\mathrm{C}_{5}$ de $88 \%$ houve redução de preço, de $88 \%$ a $100 \%$ ocorreu aumento de preço. O Quadro 3 apresenta um resumos dos trabalhos acima citados.

\begin{tabular}{|l|l|l|}
\hline \multicolumn{1}{|c|}{ Autores } & \multicolumn{1}{|c|}{ Amostra } & \multicolumn{1}{c|}{ Resultado } \\
\hline Marion et al. (1979) & $\begin{array}{l}\text { 36 cidades norte-americanas } \\
\text { e 96 produtos }\end{array}$ & relação positiva entre $\mathrm{C}_{4}$ e índice de preços \\
\hline Lamm (1988) & $\begin{array}{l}\text { 18 grandes áreas } \\
\text { metropolitanas nos EUA }\end{array}$ & $\begin{array}{l}\text { relação positiva entre índice de concentração } \\
\text { e índice de preços }\end{array}$ \\
\hline Cotteril \& Harper (1995) & $\begin{array}{l}\text { 34 mercados locais em } \\
\text { Arkansas }\end{array}$ & $\begin{array}{l}\text { relação positiva entre índice de concentração } \\
\text { e índice de preços }\end{array}$ \\
\hline Connor \& Dresher (1999) & 50 cidades alemãs em 1993 & $\begin{array}{l}\text { relação entre } \mathrm{C}_{5} \text { e preços em formato de U, } \\
\text { até } \mathrm{C}_{5}=88 \% \text { houve relação inversa, de } \\
\mathrm{C}_{5}=88 \% \text { à } 100 \% \text { o a relação foi positiva }\end{array}$ \\
\hline
\end{tabular}

Quadro 3 - Comparação entre estudos que relacionam índices de concentração e de preços.

\footnotetext{
${ }^{28}$ Marion, op. cit., p.68.

29 LAMM, R.M. Prices and concentration in the food retailing industry. Journal of Industrial Economics, v.30, p.67-77, Sep. 1981.

30 COTTRELL, P.R.; HAROER, C.D. Market power and the Demsetz quality critique: an evaluation for food retailing. Storrs: Food Marketing Policy Center, 1995. (Research Report, 29)

31 DRESCHER, K; CONNOR, J.M. Market power and economies of scale in German Food-Retailing Industry, Apr. 1999. /Unpublished manuscript/
} 
Portanto, o crescimento do poder de mercado das firmas, no setor supermercadista, não depende somente do aumento do índice de concentração, mas também da existência de uma franja, como apontado por Cyrillo (1987) e do grau de substitutibilidade entre as empresas, como observado por Dobson \& Waterson (1997). Isto pode ser observado pelo estudo de Drescher \& Connor $(1999)^{32}$, citado por Connor (1999), que mostra há relação negativa entre os índices de preços e o grau de concentração até certo um ponto (no caso $\mathrm{C}_{5}=88 \%$ ), quando ela se torna positiva.

\subsubsection{1 Índices de concentração no setor}

Os índices de concentração são um importante indicativo de poder de monopólio, como mencionado no item 2.1. Segundo Blecher (2002), as dez maiores redes eram responsáveis por 33\% das vendas mundiais em 2000, contra $28 \%$ em 1996. Na maioria dos países europeus, segundo o autor, a participação das cinco maiores empresas é superior à metade das vendas nacionais; nos Estados Unidos, este valor é de $41 \%$ e no Brasil, de 39\%, em 2001 (Figura 7).

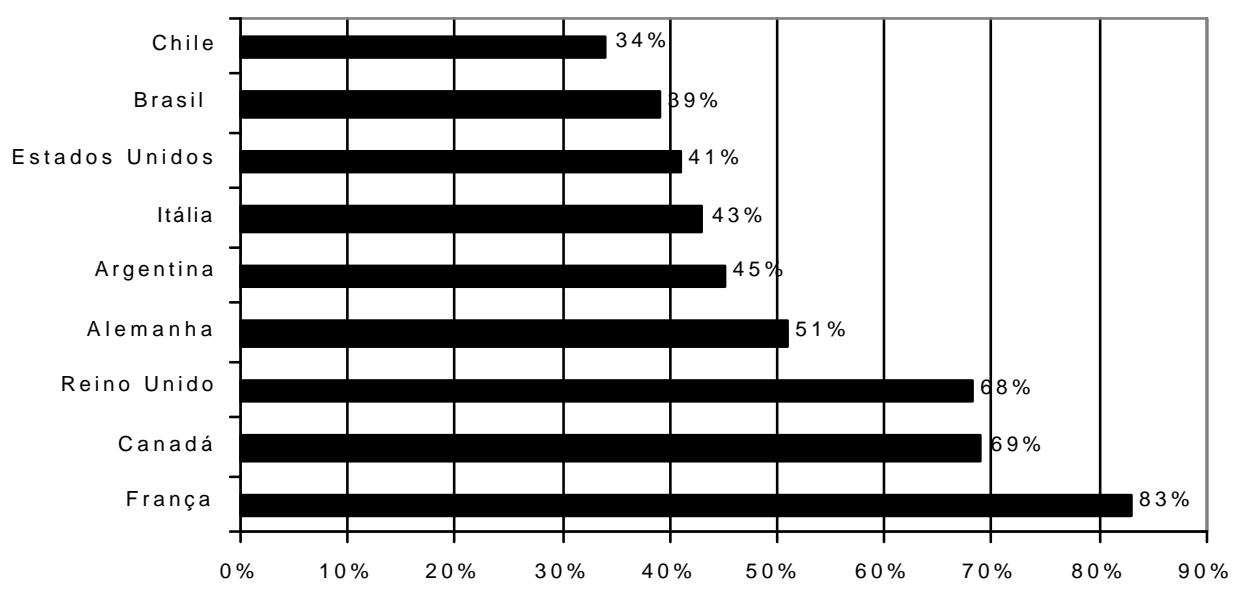

Figura 7 - Participação de Mercado das cinco maiores empresas varejistas (em \%).

Fonte: The Boston Consulting Group, citado por Blecher (2002)

\footnotetext{
${ }^{32}$ Drescher; Connor, op. cit., p.73.
} 
A ação regional, que as grandes redes de supermercado tinham, ainda se reverte em índices nacionais de concentração baixos. A grande extensão territorial brasileira faz com que seja desinteressante às grandes redes investirem em regiões de baixa densidade demográfica, cedendo este nicho para as pequenas redes ou supermercados independentes (Silva \& Famá, 1999). Porém, espera-se um aumento desses índices, pois, segundo Lepsch (2001), o aumento de concentração é consequiências de uma das estratégias comumente adotada pelas empresas varejistas: o aumento de participação no mercado.

Entretanto, segundo Connor \& Schiek (1997), dados nacionais mascaram o fato de que a concentração pode ser muito maior em nível local, que podem apresentar valores consideravelmente altos. Este fato pode ser constatado através de pareceres técnicos da Secretaria de Acompanhamento Econômico - SEAE do Ministério da Fazenda - MF, referentes aos atos de concentração no setor supermercadista, que mostram índices de concentração bem maiores para determinadas regiões.

Segundo Cavalcante (2001a), as quatro maiores redes (índice $\mathrm{C}_{4}$ ) da região metropolitana de Belo Horizonte participam com 85,2\% do mercado, isto antes do Carrefour adquirir a Organização Mineira de Supermercados, quando este índice aumenta para 93,72\%, bem acima do índice nacional. Outro exemplo ocorre na cidade de João Pessoa (PB) que possuía $\mathrm{C}_{4}$ de 94,34\% antes da compra do Supermercado Boa Esperança LTDA pela CBD (Cavalcante, 2001b).

\subsubsection{Competição vertical}

A competição vertical, destacada por Connor (1999), envolve práticas utilizadas há muito tempo, como o uso de marcas próprias, discriminação de preço por regiões geográficas, subsídios de propaganda por parte da indústria e, mais recentemente, como uso de alianças entre a indústria e o varejo para o lançamento de novos produtos, acesso a informações eletrônicas de caixas e do Intercâmbio de Dados Eletrônico (EDI) para controle de estoque. 
Cotterill (1999) afirma que, tanto nos Estados Unidos quanto na Europa Ocidental, a indústria de alimentos têm grande poder de mercado, com forte diferenciação de produtos mantidos com altos gastos em propagandas. Além disso, o processo de consolidação desse setor começou antes do varejo de alimentos.

Apesar do processo de concentração do setor supermercadista ter iniciado nos Estados Unidos, muitos países europeus têm mercados consideravelmente mais concentrados do que o americano. Entretanto, a Europa, vista como um único mercado, possui menor concentração em relação ao setor americano (Cotterill, 1999).

Segundo o autor, estas mudanças na estrutura do setor podem ajudar a compreender as inovações nas coordenações verticais, como a Resposta Eficiente ao Consumidor (ECR) ${ }^{33}$, Todo Dia Preço Baixo (EDLP), gerenciamento de categoria, entre outros. Para Cotterill (1999), o aumento da concentração do varejo local possibilitou aos supermercadistas exercerem o poder de mercado de forma mais sistemática e difusa. Desta forma, o sistema ficou predominantemente baseado em grandes indústrias vendendo para grandes varejistas.

Cotterill (1999) continua afirmando que muitos modelos de monopólio capturam os problemas de coordenação nos Estados Unidos e em alguns países europeus. Vários produtos comercializados nos supermercados, como bebidas carbonatadas, cereais matinais e cervejas, possuem oligopólios com marcas bem diferenciadas com curvas de demanda inelásticas no varejo. O uso de propaganda para a diferenciação dos produtos tende a diminuir o poder de barganha do varejo, devido à exigência dos consumidores da presença desses produtos nas lojas. Entretanto, o varejo mantém seu poder pela concentração do mercado.

Dessa forma tem-se um problema de monopólios sucessivos na coordenação de canais de distribuição e eficiência econômica. Cotterill (1999) afirma que, em casos de

\footnotetext{
${ }^{33}$ As siglas são mantidas no original, em inglês, por serem mais difundidas.
} 
markup dupla, o lucro de empresas integradas é maior do que de sucessivos monopolistas. O autor continua, declarando que, no mercado de alimentos norteamericano, ocorre aumento de lucro quando a indústria e o varejo coordenam preços ao invés de agirem independentemente. Portanto, a coordenação vertical, segundo Cotterill (1999), possibilita aumento do lucro e redução de preços para o consumidor.

Cotterill (1999) alega ainda, que o problema de coordenação vertical explica porque os movimentos estratégicos, como a Resposta Eficiente ao Consumidor (ECR), que incluía a estratégia Todo Dia Preço Baixo (EDLP), funcionaram apenas em parte nos Estados Unidos. Os ganhos obtidos com a implantação do ECR (redução nos custos logísticos devido à melhora no fluxo de mercadorias na cadeia) visavam diminuir as promoções temporárias e implantar o EDLP. Entretanto, esta estratégia não funcionou devido à falta de promoção de programas que objetivassem a coordenação dentro dos canais de distribuição e o controle ou a eliminação da marginalização dupla.

Segundo Connor (1999), os principais problemas das análises da competição vertical são que elas assumem uma relação direta entre a indústria e o varejo. Porém, cerca de $80 \%$ dos alimentos processados são comercializados através de atacadistas e a integração vertical para traz por parte do varejo varia conforme a região metropolitana do país.

Um estudo realizado por Connor \& Binkley (1998) ${ }^{34}$, citado por Connor (1999), conclui que a estrutura do mercado de atacado depende do produto comercializado. $\mathrm{O}$ aumento de concentração do atacado, que comercializa produtos não-específicos, reduz os preços no varejo devido ao aumento de eficiência. Porém, não há evidencias que isso ocorra em outros produtos como, por exemplo, refrigerados.

Igualmente, não existem evidências de aumento de eficiência pela integração vertical para trás por parte dos varejistas nesses produtos. Para produtos perecíveis,

\footnotetext{
34 BLINKEY, J.K.; CONNOR, J.M. Grocery market pricing and the new competitive environment.
} Journal of Retailing, v.74, p.273-294, 1998. 
contudo, encontra-se uma evidência fraca de efeitos positivos. Segundo os autores, aparentemente a integração no varejo ou é ineficiente ou é uma estratégia custosa (Connor, 1999).

Connor (1997), em outro estudo, afirma que as redes varejistas com alto volume comercializado em determinadas áreas investem em estrutura de atacado, devido ao aumento de eficiência operacional e por razões estratégicas. Segundo o autor, algumas ações lucrativas para o atacado podem levar a resultados sub-ótimos para o varejo e vice-versa. Por exemplo, para o atacado é desejável entrega menos freqüente e com maior volume, enquanto o varejo espera o inverso, permitindo a redução de itens estocados na loja e do risco de vencimento dos produtos. Outros problemas observados são horários de entrega de mercadorias (o varejo prefere períodos de menor movimento na loja, que podem não ser compatíveis com os horários dos atacadistas), mix de produtos adequados à clientela do varejo e compatibilidade de sistema de informação. Além desses fatores, o investimento em estrutura atacadista representa comprometimento com o mercado, devido aos sunk costs relacionados. Esta estrutura pode, ainda, ser super dimensionada, resultando em excesso de capacidade, o que desencorajaria a entrada de novos concorrentes (Connor, 1999).

No mesmo estudo, o autor acrescenta que os atacadistas de produtos de linhas gerais vendem para uma ampla gama de varejistas que operam com menos de 40 lojas, para as quais não são rentáveis as manutenções de uma estrutura atacadista. Esses atacadistas procuram atender a maior diversidade de clientes, visando reduzir os riscos de perda de receita pela saída de um cliente. Caso os atacadistas se concentrassem em atender poucos clientes grandes, a perda de um causaria grande redução de receita.

Outra alteração nas relações verticais é apontada por Farina \& Reardon (2000). Segundo os autores, as mudanças de política na década de 90 levaram à abertura dos mercados nos países do Mercosul. Antes desse processo, a política alimentar incluía fixação de preços, subsídios, altas tarifas de importação de produtos processados e limitações aos investimentos estrangeiros. Esta política limitou a possibilidade de 
entrada de novas firmas, tanto nacionais como estrangeiras, e oportunidades de diferenciação de produtos, porém manteve os preços dos alimentos baixos.

Segundo Farina \& Reardon (2000), os programas de liberalização do mercado resultaram em grande crescimento da competição e, posteriormente, ao aumento na concentração do mercado de alimentos e internacionalização de seu capital, através de aquisições e fusões. Este processo também foi acompanhado mais a frente na cadeia de alimentos com os supermercados, fast-foods, entre outros. O novo padrão de competição exigiu novas estratégias de sobrevivência das empresas que estabeleciam melhorias na qualidade e segurança dos alimentos.

Como processo de internacionalização e concentração ocorreu tanto na indústria de alimentos, um dos principais fornecedores do setor supermercadista, quanto no setor de auto-serviço, houve reflexo nas negociações entre indústria e comércio. Blecher (2002a) afirma que as relações entre fornecedores e grandes varejistas sempre foram complicadas. Segundo Chiara (2000b), no período de inflação alta, o poder de negociação estava com os fornecedores que incorporavam automaticamente os ajustes de preço. Porém, a situação começou a se inverter nos anos 90, segundo Blecher (2002a), com a abertura da economia e a estabilidade que surgiu após o Plano Real, que viabilizou os investimentos estrangeiros no setor supermercadista, resultando em um processo de fusões e aquisições e aumento de concentração.

Chiara (2000b) afirma que, com a estabilização da moeda e a crescente consolidação do varejo, as grandes redes fortaleceram-se nas negociações. Entre as exigências dos supermercados junto aos fornecedores, segundo a autora, está o pagamento de taxas para manutenção dos produtos expostos nas prateleiras, participação em promoções de aniversário, dar descontos e entrar com o "enxoval" (uma quantidade de produtos a título de bonificação na inauguração de uma nova loja). Segundo Demarchi \& Tuszel (2000), essas exigências podem variar entre oito e $14 \%$ do valor de cada venda.

Segundo Blecher (2002a), a indústria de bens de consumo, em contrapartida ao 
aumento de força do varejo, está alterando sua estratégia de venda. Nos anos 80, segundo o autor, essa indústria terceirizara as vendas de clientes pequenos e médios para atacadistas e distribuidores visando reduzir custos, baseado no paradigma que maiores volumes significavam menores custos e maior lucratividade. Contudo, o fortalecimento das grandes redes tornou as negociações mais duras e geraram perdas aos fornecedores. Por esse motivo, passou a ser mais vantajoso para a indústria negociar com as redes médias, forçando-a a adaptar-se aos novos clientes (Blecher, 2002a).

\subsubsection{Competição geográfica}

Nos Estados Unidos - com algumas exceções, como o WarMart - não existiam redes de supermercados com presença nacional. O processo de fusões nos Estados Unidos, segundo Connor (1999) acelerou-se na década de 80, depois de um período de estabilidade. O mesmo fenômeno, segundo o autor, foi observado na Europa.

Segundo Gurdjian et al. (2000), na Europa, o volume de aquisições no setor quadruplicou entre os anos de 1994 e 1998, passando de US\$ 2,9 bilhões para US\$ 12,4 bilhões, respectivamente. Os autores afirmam que as aquisições de melhor resultado na Europa ocorreram em seus países de origem, onde as economias de escala são mais facilmente alcançadas. Os custos de negociação entre supermercados e fornecedores de firmas como, por exemplo, Comptoirs Modernes, na França, e Allfauf e Kriegbaum, na Alemanha, compradas por Carrefour e Metros respectivamente, reduziram em torno de dois por cento, e a combinação de custos logísticos, de tecnologia de informação, da administração centralizada podem reduzir os custos em mais um ou dois por cento (Gurdjian et al., 2000).

Connor (1999) afirma que o varejo europeu investiu mais em mercados estrangeiros do que o varejo americano. Segundo Gurdjian et al. (2000), a entrada do Wal-Mart no mercado europeu (tornando-se a quarta maior cadeia de hipermercados na Alemanha em seis meses, forçando uma reestruturação no setor) e a necessidade de crescer (devido à saturação dos mercados nacionais) forçaram as grandes cadeias de 
supermercados europeus a buscarem novos mercados em países estrangeiros. Esses investimentos internacionais, segundo Connor (1999), ocasionaram mudanças nas práticas administrativas do setor.

Para Incandela et al. (2000), a expansão internacional permite aos varejistas um ciclo virtuoso de vantagens competitivas. $\mathrm{O}$ crescimento em escala permite, segundo os autores, melhorar a eficiência na obtenção de produtos, de tecnologia de informações e de propaganda. Isto possibilita aumentar suas margens, e, por consequiência, ter maior capacidade de investimento, por exemplo, em ativos intangíveis, como marca e talentos. Com isso, quanto mais o varejo expande-se geograficamente, maiores são os seus lucros, incrementando a possibilidade de investir em crescimento geográfico e em ativos (Incandela et al., 2000).

A busca de expansão geográfica pelas grandes redes acontece porque sua área de influência é limitada aos locais em que possui estabelecimentos, ou seja, a competição entre os varejistas ocorre em nível local. Ferreira et al. (2001) definem a área de influência de uma loja como a área geográfica que possui a maior parte dos consumidores desse estabelecimento. Essa área está relacionada ao tipo de loja (se minimercado, supermercado pequeno, supermercado grande, hipermercado) e à densidade populacional (se baixa, média ou alta). Nesta área se encontrariam cerca de $70 \%$ do total dos clientes da loja. As dimensões típicas de influência dos supermercados encontrados para o Brasil são apresentadas na Tabela 8.

Tabela 8. Área de influência de supermercados.

\begin{tabular}{lcc}
\hline Tipo de loja & $\mathrm{N}^{\mathbf{o}}$ de Caixas & Area de Influência $(\mathrm{km})$ \\
\hline Supermercado pequeno & de 03 a 19 & 1,8 \\
Supermercado grande & de 20 a 40 & 2,5 \\
Hipermercado & mais de 40 & 5,0 \\
\hline
\end{tabular}

Fonte: Ferreira et al. (2001) 


\subsubsection{Condições de entrada}

As barreiras à entrada de novas empresas ou abertura de novas lojas no setor supermercadista alteraram-se ao longo do desenvolvimento do setor. Segundo Cyrillo (1987), até início da década de 60, o setor apresentava altas barreiras que inibiam sua rápida expansão apesar das vantagens das economias de escala que os supermercados possuíam, em relação aos varejistas tradicionais.

As principais barreiras à entrada naquele período eram: (i) as incertezas para os investimentos gerados pela não regulamentação dos supermercados, que ocorreu apenas em 1968; (ii) o hábito de consumo que dava preferência ao atendimento personalizado em balcão dos varejos tradicionais; (iii) os custos operacionais que os supermercados tinham e as lojas tradicionais não possuíam, como abrigar, além da loja, a moradia do seu proprietário; (iv) a concorrência desleal, resultado da sonegação fiscal, principalmente do Imposto sobre Vendas e Consignações (IVC), pelo varejo tradicional, que era dificultada nos supermercados devido à estrutura administrativa na qual os funcionários faziam registro mecânico das vendas, juntamente com isenções de impostos a outras atividades, como cooperativas de consumo que concorriam com os supermercados; (v) a inexistência de linhas de crédito resultado do risco da atividade e a concorrência com o varejo tradicional; (vi) as taxas de inflação crescentes, no final da década de 50 e início de 60, também geravam barreiras à entrada de novas empresas e lojas de supermercados, pois estas tinham maior dificuldade de remarcação de preços em relação ao comércio tradicional, que no atendimento pelo balcão podia alterar os preços mais facilmente (Cyrillo, 1987).

A regulamentação do setor, substituição do IVC pelo Imposto sobre Comercialização de Mercadorias (ICM) e, posteriormente, pelo ICMS, e a abertura de crédito para o setor reduziram muito as barreiras à entrada.

Atualmente as principais barreiras, segundo Ferreira et al. (2001), são:

- existência de custos irrecuperáveis ( sunk costs); 
- os gastos em publicidade podem representar importantes barreiras principalmente às empresas que desejam fixar uma imagem forte. A existência de economias de escala relacionadas à publicidade limita sua utilização a grandes redes nacionais ou regionais que possuam recursos para este fim. Porém, esses gastos, apesar de não serem desprezíveis, têm um papel menos relevante na atração dos consumidores, pois o mercado relevante é o local. Por isso, as empresas sem exigência de fixação de imagem possuem barreiras à entrada menores, pois os gastos com propaganda tendem a ser menos relevantes;

- a fidelidade do consumidor às redes estabelecidas obriga às firmas a despenderem recursos adicionais para convencer o consumidor local a redirecionar suas compras.

- a existência de vantagens absolutas das firmas já estabelecidas, que não podem ser facilmente reproduzidas pelas possíveis novas firmas;

- maior conhecimento do mercado por parte da empresa estabelecida em relação às entrantes, por exemplo, dos hábitos dos consumidores locais;

- realização de contratos com fornecedores, adequados para atender às demandas específicas de cada região;

- escolha correta da localização do estabelecimento, por ser um fator importante, para o consumidor, na opção pela loja;

- barreiras legais e regulatórias, que são exigências governamentais para a instalação e funcionamento de uma empresa, como limitações de grandes construções em determinadas áreas;

- economias de escala obtidas, entre outras formas, pela racionalização logística (como a criação de centro de distribuição ou depósito, o que é viável somente com um número de lojas que justifiquem a manutenção dessa estrutura), aumento do "poder de negociação" junto aos fornecedores, com aumento do volume das compras.

- retaliação por parte dos competidores instalados, que podem praticar preços inferiores aos praticados antes da entrada do novo competidor, ou ainda realizações de promoções. 
As barreiras à entrada, contudo, podem ser reduzidas adquirindo-se estabelecimentos já existentes. Esta estratégia, comumente utilizada por grandes redes para expandir sua área de atuação, permite restringir as vantagens absolutas das firmas já existentes, obtendo o conhecimento de mercado e de fornecedores através dos funcionários antigos, diminuir a retaliação pelos concorrentes, e adquirir a fidelidade do consumidor, por já ser conhecido na região. Parte destas barreiras também são reduzidas com a utilização da estrutura existente, como uso do departamento de compra, contratos com fornecedores e gastos com publicidade, por exemplo.

Ferreira et al. (2001) ainda acrescentam que o acesso a tecnologias, insumos e pessoal especializado não são barreira à entrada, na medida em que não são específicos da atividade supermercadista e são facilmente obtidos na atividade varejista em geral. Os níveis de tecnologia e insumos são relativamente baixos em relação a outras atividades econômicas tais como as industriais. $\mathrm{O}$ dispêndio com máquinas e equipamentos também não são considerados relevantes como barreiras à entrada, pois apresentam um pequeno grau de especificidade e existe um mercado de aluguel para esses equipamentos que reduzem as perdas, apesar do alto grau de depreciação física e tecnológica desses equipamentos.

Desta forma, conclui-se que o nível de barreiras à entrada é relativamente baixo, o que pode ser observadas indiretamente pelo grande volume de novas empresas que surgiram no setor nos últimos anos, como mostra a Tabela 9.

Tabela 9. Crescimento percentual no número de empresas no setor de varejo de alimentos no Brasil.

\begin{tabular}{lcc}
\hline & $98 / 99$ & $99 / 00$ \\
\hline Hipermercados e supermercados & $13,7 \%$ & $25,1 \%$ \\
Outros tipos de comércio de alimentos ${ }^{*}$ & $14,2 \%$ & $5,57 \%$ \\
Total & $12,4 \%$ & $6,36 \%$ \\
\hline
\end{tabular}

Fonte: Instituto Brasileiro de Geografia e Estatística - IBGE (2002)

(*) Não-especializado com predominância de produtos alimentícios (lojas com menos de $300 \mathrm{~m}^{2}$ - mercearias, armazéns, empórios, etc.- e lojas de conveniência.). 
Outra característica do setor em relação às condições de entrada, citadas por Cavalcante et al. (2001), é a possibilidade de uma entrada "tempestiva", ou seja, a capacidade da entrada ocorrer em um período igual ou inferior a dois anos. Segundo os autores, a construção e instalação de uma loja de supermercado varia de três a cinco meses, caso ocorra em uma edificação preexistente, o prazo reduz-se para cerca de dois meses. No caso dos hipermercados, a construção e instalação ocorrem entre seis e doze meses, e diminui para três meses em construções preexistentes.

Essas características do setor, baixas barreiras e entrada "tempestiva", reduzem o poder de monopólio dos supermercados, pois novos estabelecimentos podem ser abertos caso os já existentes tentem obter ganhos monopolistas, aumentando a concorrência local.

\subsubsection{Economias de escala}

Segundo Lepsch (2001), a empresa varejista pode possuir desde monoformato até múltiplos formatos (como hipermercados, supermercados, clubes de compra etc.) visando ampliar os seus segmentos-alvo. Esta diversificação é motivada pela busca de economias de escala e de escopo, além da obtenção de sinergias financeiras, redução de custos de transação e obtenção de objetivos administrativos.

Lepsch (2001) afirma que economias de escala são possíveis em diversos pontos das empresas supermercadistas, como nas compras, nas promoções, na expansão da rede, na operação da loja, entre outros. As economias de escala nas compras, segundo o autor, ocorrem devido à diluição dos custos fixos da estrutura de compra e do aumento do poder de barganha proporcionados pelo grande volume transacionado, o que reduz os preços unitários dos produtos.

As economias de escala ocorrem também nas promoções. Consideradas custos fixos, as promoções têm como objetivo aumentar as vendas dos produtos comercializados pelo supermercado. Quanto maior a compra de espaços publicitários, menor é o seu custo unitário. Além disso, a eficiência da promoção melhora com o 
aumento do número de lojas da rede coberta pela propaganda (Lepsch, 2001).

As grandes redes têm ainda a vantagem de obter preços menores pelo capital, como pelo lançamento de ações no mercado, por operação de financiamento internacional etc. Os pequenos varejistas, entretanto, são vistos como clientes de alto risco pelos bancos tendo acesso a financiamentos a custos mais elevados, e não têm como abrir seu capital (Lepsch, 2001). Portanto, há também economias de escala no financiamento.

Lepsch (2001) aponta, ainda, outras economias de escala no setor como; (i) na expansão da rede, que ocorre pela multiplicação de lojas padronizadas, diluindo os custos de planejamento e da elaboração do modus operandi das diversas lojas; (ii) na operação, os custos operacionais da loja aumentam proporcionalmente menos do que o do tamanho da loja, dando vantagens operacionais aos hipermercados em relação às lojas menores, possibilitando a adoção de markups menores; (iii) nos imóveis, por poder explorar melhor as oportunidades do mercado imobiliário, pois este investimento fixo é relevante e seu retorno, demorado e (iv) de escopo, os supermercados podem oferecer, além de bens de consumo diário, serviços financeiros e espaços para lojas satélites como lavanderias, casas lotéricas, agências bancárias etc.

O ganho de escala é mais significativo quando a densidade de lojas é alta numa mesma região geográfica por utilizar a mesma estrutura de distribuição. Por esse motivo as grandes redes mantiveram seu foco em nível regional. Como exemplo, o Sonae focalizado na região Sul, o Grupo Pão de Açúcar e Carrefour, em São Paulo, Sendas, no Rio de Janeiro, e o Bompreço, no Nordeste (Silva \& Famá, 1999).

Porém, atualmente, buscando aumentar seus mercados, as grandes redes estão ampliando suas atividades para outras regiões. O Grupo Pão de Açúcar, por exemplo, através de abertura de estabelecimentos próprios e de aquisição de outras redes, está atuando também nas regiões nordeste, sul e centro-oeste. O grupo Sonae está abrindo hipermercados em São Paulo, Rio de Janeiro, Espírito Santo e Minas Gerais. O grupo Carrefour estendeu seu mercado para todos os estados do país. 
O ganho de escala talvez seja o fator mais importante dentre as causas do aumento da concentração do setor, segundo Silva \& Fama (1999). O processo de concentração do setor resultaria, portanto, da busca das empresas por ganhos operacionais.

\subsection{6 Índices de desempenho}

Souza (2000a) afirma que o aumento da média percentual dos lucros líquidos no setor está relacionado aos investimentos em tecnologia e qualificação de mão-de-obra. Segundo o autor, as empresas de médio porte, percebendo o aumento da concorrência, investiram em tecnologia e métodos concorrenciais. As pequenas empresas, ainda para o autor, estão ocupando novos nichos de mercado e ganhando competitividade à medida que se reúnem em associações (Tabela 10).

Tabela 10. Média percentual do lucro líquido sobre faturamento bruto.

\begin{tabular}{ccccc}
\hline & 1998 & 1999 & 2000 & $2001^{(")}$ \\
\hline Média de lucro líquido (\%) & $1,5 \%$ & $1,3 \%$ & $1,8 \%$ & $2,0 \%$ \\
\hline
\end{tabular}
Fonte: Souza (2002a, p.24)

(*) Base: 389 empresas respondentes.

Sesso Filho (2001), utilizando a análise fatorial pelo método dos componentes principais, estudou o crescimento e o desempenho de 20 redes supermercadistas no período de 1994 e 2000. Para o cálculo de crescimento, foram utilizadas as variáveis de faturamento bruto, total de caixas, total de lojas, área de venda total e número de funcionários e para a estimativa de desempenho, foram empregados os índices de faturamento bruto por caixa, por área e por número de funcionários.

$\mathrm{O}$ autor observou que as empresas que apresentaram grande crescimento no período não tiveram necessariamente os melhores índices de desempenho. Para o autor, isto se deve a três fatores principais: (i) ao crescimento das maiores redes pela aquisição de redes de porte médio, menos eficientes, (ii) à abertura de lojas em novas regiões que geralmente são menos populosas e/ou com poder aquisitivo menor, diminuindo o 
desempenho desses novos estabelecimentos e (iii) ao aumento da rivalidade, causado pela entrada de empresas estrangeiras e pelo aumento da concentração, que influenciou a redução no desempenho de todas as redes e estimulou gastos com novos equipamentos (Sesso Filho, 2001).

Sesso Filho (2001) acrescenta, ainda, que, apesar da redução no desempenho das maiores redes, deve-se considerar a diminuição nos custos gerados principalmente pela economia de escala e aumento do poder de barganha junto aos fornecedores. Essa redução no custo operacional pode compensar, ou até superar, a maior ineficiência nas vendas.

\subsubsection{Padrões de concorrência}

A Tabela 11, elaborada por Rojo (1998), apresenta os principais atributos para a escolha do supermercado. Observa-se que os preços, ofertas e promoções são os principais predicados na escolha pelo estabelecimento, tanto para as classes $\mathrm{A} / \mathrm{B}$, quanto C/D. Ferreira et al. (2001) afirmam que o preço cobrado pelo supermercado não deve ser entendido como o preço de um único produto, mas de uma suposta cesta que o consumidor decide comprar, pois os clientes não têm, em geral, clareza quanto aos preços relativos vendidos individualmente. Isto permite, segundo os autores, que os supermercados cobrem uma margem maior nos produtos que têm menor elasticidade preço da demanda e menor giro. Para os autores, os consumidores escolhem os supermercados com base na "reputação" das redes, relacionada à variedade, qualidade dos produtos e principalmente preços. 
Tabela 11. Atributos mais citados para a escolha do local de compras.

\begin{tabular}{lccc}
\hline Atributos & Classe A/B & Classes C/D & Total \\
\hline Preços, ofertas e promoções & $25 \%$ & $28 \%$ & $27 \%$ \\
Atendimento & $17 \%$ & $19 \%$ & $18 \%$ \\
Qualidade/Higiene/Limpeza & $18 \%$ & $17 \%$ & $17 \%$ \\
Variedade & $11 \%$ & $10 \%$ & $10 \%$ \\
Crédito & $9 \%$ & $7 \%$ & $8 \%$ \\
Rapidez no caixa & $8 \%$ & $7 \%$ & $7 \%$ \\
Perecíveis & $5 \%$ & $8 \%$ & $7 \%$ \\
Outros & $7 \%$ & $4 \%$ & $6 \%$ \\
\hline
\end{tabular}

Fonte: Rojo (1998, p.133)

Nota: Base 1.400 entrevistas em S. Paulo, Rio de Janeiro, Minas Gerais e região sul do Brasil.

Dessa forma, é muito comum os supermercados escolherem uma cesta de produtos chave e promovê-los junto aos consumidores para criar uma boa "reputação". Esta estratégia fundamenta-se principalmente na redução dos preços e induz os consumidores a comparar os supermercados com base na cesta anunciada (Ferreira et al., 2001).

Rojo (1998) afirma, entretanto, que os supermercados devem oferecer também bom atendimento, qualidade, higiene e variedade para serem capazes de manterem os clientes. Estes itens aparecem praticamente com a mesma frequiência. Para o autor, os supermercadistas apontam, também, o atendimento como a variável mais importante, depois dos preços para a fidelização dos clientes.

Ferreira et al. (2001) acrescentam que o fornecimento de serviços melhores e diferenciados com relação aos rivais é uma forma eficaz de se obter vantagens competitivas. Os autores citam como exemplo desses serviços o ambiente de vendas (por exemplo, limpeza, disposição dos produtos e bom atendimento), serviços fornecidos gratuitamente (como estacionamento e cartão do supermercado) ou outros serviços agregados à loja (como farmácia e lanchonetes). Entretanto, segundo os autores, a utilização dessa estratégia, por ser muito custosa, depende do grau de rivalidade existente no mercado. 
Segundo Rojo (1998), a qualidade do estabelecimento está relacionada principalmente ao padrão arquitetônico e tecnológico das lojas e dos produtos perecíveis. A percepção de qualidade por parte do cliente, segundo o autor, é percebida pelos perecíveis e reforçada pelo layout da loja. Os produtos industrializados são iguais em todas as lojas, mas a diferença de qualidade entre os estabelecimentos é evidenciada pelas frutas e verduras.

A variedade, ainda segundo o autor, também é um atributo relevante na escolha do supermercado, porém tão importante quanto ela é a constância da presença dos produtos no ponto-de-venda. Ferreira et al. (2001) acrescenta que as redes que sabem melhor o desejo do consumidor ou que possuem uma área de venda que permita dispor uma maior variedade de produtos costumam ter vantagens em relação às demais. Segundo os autores, os produtos de marca própria ajudam também a diferenciar os supermercados, seja por disponibilizar produtos de melhor qualidade ou com menor preço. No primeiro caso, o consumidor associa a qualidade do produto de marca própria ao supermercado.

A localização, para Ferreira et al. (2001), também é uma estratégia de diferenciação. A facilidade de acesso e a proximidade com os consumidores tendem a atrair a demanda de clientes ao supermercado, e, ainda, segundo os autores, servir como barreira à entrada de novos competidores. Como a rivalidade entre os supermercados é, em grande medida, locacional, as redes podem decidir abrir um número maior de lojas em uma dada região, buscado as melhores localidades, para desestimular a entrada de novos concorrentes (Ferreira et al., 2001).

O crédito, através de cheques pré-datados e cartões, é outro aspecto que atrai os consumidores, mas como é praticado pela maioria dos supermercados, apresenta um diferencial competitivo pequeno. A rapidez nos caixas também é um aspecto importante e está associada ao atendimento e é um dos principais pontos de estrangulamento nos supermercados (Rojo, 1998). 


\subsubsection{Políticas públicas}

Conforme Gremaud et al. (2002), o Brasil passou por intensa atividade reformista a partir do final dos anos 80. Neste período, houve a abertura comercial e da Conta Capital, reforma fiscal, administrativa, de seguridade social e financeira, além das privatizações.

Entre as mudanças destaca-se a abertura comercial, desregulamentação e a redução da inflação. Pinheiro et al. (2001), em um estudo sobre as transformações da economia brasileira na década de 90, afirmam que entre os anos de 1988 e 1993 o governo reduziu drasticamente a proteção dos produtos nacionais, através da redução das tarifas médias sobre importações e a eliminação de barreiras não-tarifárias. Esta liberalização, segundo os autores, foi particularmente importante para os bens de consumo, proporcionando aos consumidores acesso legal a produtos estrangeiros.

Os autores acrescentam que o governo, visando aumentar a competição no mercado interno, liberou um grande número de controles administrativos que foram criados durante o período de substituição às importações. Além de criar um pacote de medidas com o objetivo de fortalecer as políticas de combate aos monopólios e de proteção ao consumidor, como a lei antimonopólio de 1994 que consolidou as leis sobre a concorrência no mercado e estabeleceu penalidades mais severas e respostas jurídicas mais rápidas em caso de infração.

Gremaud et al. (2002) afirmam que a ausência de choques e congelamentos entre os anos de 1991 e 1993 deram a inflação brasileira um caráter inercial. Neste período, o país acumulou um volume significativo de reservas internacionais, devido ao aumento do fluxo voluntário de recursos externos e a economia estava mais aberta à concorrência, dado ao processo de abertura comercial, que limitava a capacidade dos agentes de repassarem os choques aos preços. Dentro deste quadro, foi implementado o Plano Real, que segundo os autores, pode ser dividido em três fases: ajuste fiscal, indexação completa da economia (criação da Unidade Real de Valor - URV) e reforma monetária (transformação da URV em Real). 
O resultado desse plano, segundo Gremaud et al. (2002), foi a rápida queda da taxa de inflação nos meses seguintes. Outra consequiência foi um grande crescimento na demanda e da atividade econômica. Os autores afirmam que o aumento da demanda, mesmo com políticas monetárias restritivas (como taxas de juros elevadas), pode ser explicada, entre outros fatores, pelo aumento do poder aquisitivo das classes de baixa renda, proveniente da redução do "imposto inflacionário", que ocorria mesmo com a indexação dos salários a URV, pois estes eram corrigidos até a data do pagamento, mas perdiam o valor de compra ao longo do período de gastos dessa população por não ter acesso às aplicações.

\subsection{O setor supermercadista brasileiro após o Plano Real}

O setor supermercadista, no período de altas taxas inflacionárias, obtinha a maior parte de seus lucros com os ganhos financeiros. $\mathrm{O}$ fato dos supermercados comprarem os produtos a prazo e os venderem à vista proporcionava-lhes ganhos tanto com a desvalorização da moeda, causada pela inflação, quanto nas aplicações no mercado financeiro. Com a redução da inflação, estes ganhos financeiros caíram, pressionando os supermercados a se adaptarem à nova realidade. O comportamento dos consumidores também foi influenciado pela estabilização econômica, permitindo-lhes compras menores e mais frequientes. Estas alterações no ambiente influenciaram a conduta dos supermercados.

Silveira \& Lepsch (1997) apresentam três hipóteses sobre as tendências do setor supermercadista após o plano Real. São elas: (i) aumento da concorrência, (ii) mudança da ênfase da administração, do financeiro para operacional e (iii) manutenção no sistema de precificação.

Para os autores, apesar da necessidade de estudos mais aprofundados, pode-se dizer que após o Plano Real houve diminuição na diferença dos preços entre as redes, o mix de produtos das lojas aumentou, os ganhos financeiros diminuíram, o markup aumentou (Tabela 12) e manteve-se como base da precificação. Foram tomadas, 
também, medidas para aumentar a eficiência operacional e o preço continua sendo o principal atributo para a escolha da loja pelo consumidor (Silveira \& Lepsch, 1997).

Tabela 12. Margens de comercialização (markup) em supermercados antes e após a implementação do Plano Real (1994).

\begin{tabular}{lcc}
\hline \multicolumn{1}{c}{ Seções } & \multicolumn{2}{c}{ Margem-objetivo } \\
\cline { 2 - 3 } & Pré-Real & Pós-Real \\
\hline Mercearia alimentícia & $11,8 \%$ & $15,6 \%$ \\
Mercearia não alimentícia & $14,5 \%$ & $18,5 \%$ \\
Mercearia líquida & $15,4 \%$ & $17,8 \%$ \\
Perecíveis & $10,2 \%$ & $15,6 \%$ \\
Refrigerados/Congelados & $11,7 \%$ & $16,6 \%$ \\
Hortifrutigranjeiros & $13,0 \%$ & $19,5 \%$ \\
Padaria & $35,3 \%$ & $44,5 \%$ \\
Bazar/Eletrônicos & $24,8 \%$ & $30,8 \%$ \\
Têxtil/Magazine & $25,4 \%$ & $33,2 \%$ \\
Cesta básica ampliada & $4,9 \%$ & $8,0 \%$ \\
\hline
\end{tabular}

Fonte: Lepsch (1996)

Nos anos 70, as grandes redes adotavam um modelo de abastecimento das lojas caracterizado pela descentralização. Atualmente a tendência é de centralização, ou um modelo misto, no qual determinadas mercadorias são obtidas pelas centrais de compra, enquanto outras vêm diretamente dos fornecedores (Santos \& Gimenez, 1999). Esta estratégia permite o aproveitamento de economias de escala - pelo rateio dos custos de utilização de uma estrutura para diversas lojas ou por um volume maior de compras - e pelo poder de barganha - proporcionado pelo maior volume adquirido pela diminuição do número de fornecedores - o que torna o varejista um cliente importante (Silva \& Famá, 1999).

\subsubsection{Automação comercial}

A automação comercial, no Brasil, tomou força na segunda metade da década de 90, como se pode observar na Figura 8, objetivando melhorar a eficiência e o controle operacional. Ela se iniciou pelas grandes redes, que investiram em novos equipamentos, 
mas as empresas menores, visando também melhorar o atendimento ao cliente, adotaram igualmente as novas tecnologias, principalmente os caixas automatizados. Segundo Gonçalves (2000), as novas tecnologias desenvolvidas neste período passaram a fazer parte do varejo e de seus fornecedores, agilizando a comunicação e mudando as formas de fazer negócio.

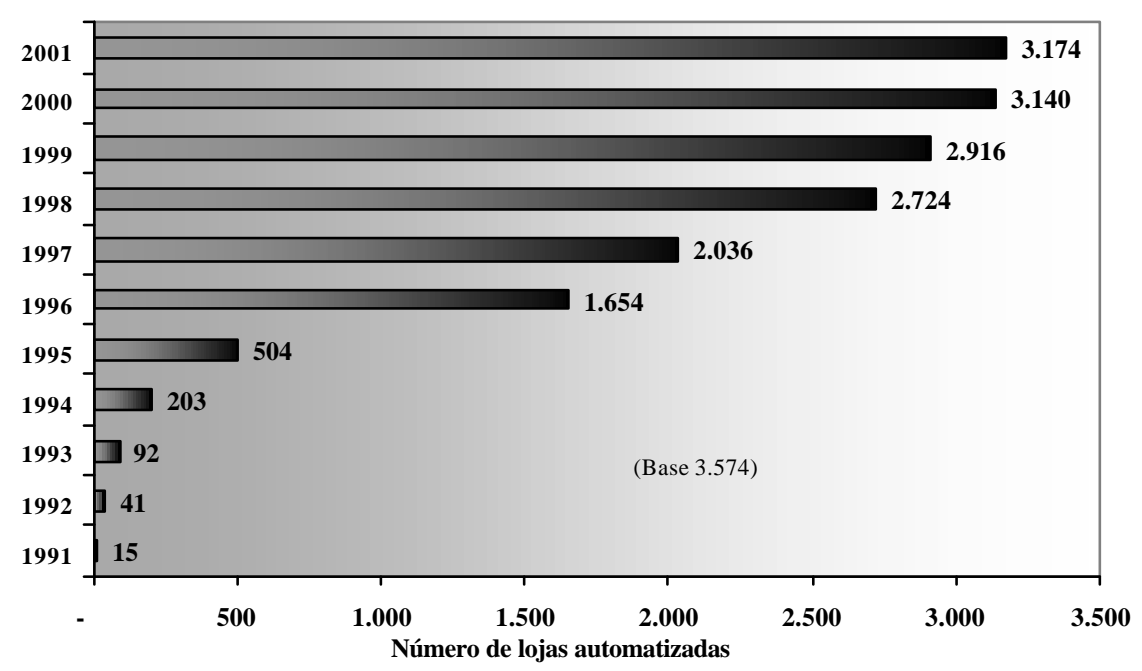

Figura 8 - Automação comercial no setor supermercadista brasileiro.

Fonte: Souza (2002a, p.22)

O processo de automação pode ser dividido basicamente em duas partes: automação de frente e de retaguarda. A primeira relaciona-se ao uso de leitores de código de barras e máquinas de preenchimento de cheques e visa gerar informações sobre as vendas e reduzir o tempo de atendimento ao cliente (em cerca de 30\%), diminuindo as filas e possibilitando o aumento da área de exposição, pela redução no número de caixas. A segunda, automação de retaguarda, tem como objetivo analisar as informações geradas na loja e gerar relatórios (Automação de retaguarda..., 1996).

Entre as inovações tecnológicas encontra-se a Resposta Eficiente ao Consumidor (Efficient Consumer Response - ECR). Esta é uma estratégia que busca estabelecer 
vínculos mais próximos entre o varejo, fornecedores e indústria, visando melhorar a eficiência na distribuição dos produtos e informações e proporcionar maior valor ao consumidor. Ela é composta por quatro estratégias, (i) sortimento da loja, (ii) sistema de reposição, (iii) promoções e (iv) introdução de novos produtos (Dib, 1997).

A primeira estratégia, denominada Efficient Store Assortment (Sortimento Eficiente da Loja), tem como objetivo otimizar os estoques e o espaço das lojas visando encontrar o mix ideal de mercadorias que atenda às demandas dos consumidores, aumentando o volume de venda e eduzindo os estoques das lojas. A segunda estratégia, sistema de reposição, visa otimizar o tempo e o custo do sistema de reposição dentro do estabelecimento e recebe o nome de Efficient Replenishment (Reposição Eficiente). As estratégias de promoção, denominadas de Efficient Promotion (Promoção Eficiente), visam maximizar a eficiência de todos os sistemas de promoções de venda, do fornecedor ao cliente. Finalmente, a última estratégia chamada de Efficient Product Introduction (Introdução Eficiente de Produto), busca maximizar a eficácia do desenvolvimento e introdução de novos produtos (Dib, 1997).

O gerenciamento de categorias é uma das ferramentas utilizadas pelo Efficient Store Assortment e apontado como outra inovação recente do setor. Segundo Santos \& Gimenez (1999), o gerenciamento visa entender a racionalidade do consumidor no momento da compra, procurando distribuir as seções da loja e os produtos nas gôndolas eficientemente, segundo a preferência do consumidor e a maximização dos resultados das vendas. Entre outros benefícios, destacam-se: conhecimento sobre o lucro de cada marca, melhora na organização e imagem da loja (atraindo mais consumidores), aumento das vendas por impulso, por conveniência e por produtos complementares.

Parte integrante da ECR, o Electronic Data Interchange - EDI (Intercâmbio Eletrônico de Dados) consiste na troca de dados entre dois computadores via telecomunicação. Suas vantagens consistem na redução de erros nos pedidos, no custo de mão-de-obra e no tempo entre o pedido e a entrega, por eliminar a necessidade de redigitação de informações e uso de papel (Takaoka \& Navajas, 1997). 
Entretanto, a implementação do ECR é cara e seu retorno não é imediato, por esses motivos muitas lojas não estão podendo implementar este sistema de forma completa, apesar dos grandes benefícios estimados. Nos Estados Unidos, o ECR tem um potencial de reduzir os custos dos supermercados com inventário, requisição de produtos, fatura, e pagamento em 30 bilhões de dólares, e na Europa, de 33 bilhões de dólares (Kruma, 1997).

\subsubsection{Alterações nos hábitos dos consumidores}

A estabilização econômica, após a implantação do Plano Real em 1994, também influenciou os hábitos de consumo, modificando as características de demanda dos produtos nos supermercados. Isto ocorreu, pois houve, em um primeiro momento, aumento da renda da população, ocasionado pelo fim do imposto inflacionário, e a possibilidade de compras menores e mais distribuídas ao longo do mês, sem redução significativa no valor da moeda.

Segundo Bertasso (2000), o consumo de alimentos da população metropolitana, nos anos de 1995/96, foi fortemente condicionado pela renda, que influencia positivamente a frequiência de compras e também o tipo de alimentação. Como se pode observar pela Tabela 13, as despesas com alimentação possuem elasticidade-renda positiva, ou seja, aumento na renda gera crescimento do consumo. Os alimentos considerados "modernos", como os pré-preparados, possuem elasticidade-renda média maior do que os produtos "tradicionais", como arroz e feijão, que necessitam maior tempo de preparo, evidenciando que o consumo do primeiro aumenta mais do que a demanda dos "tradicionais", com a elevação da renda. 
Tabela 13. Elasticidade-renda da despesa de alimentos no Brasil em 1995/96.

\begin{tabular}{lc}
\hline Tipo de despesa & Elasticidade média \\
\hline Alimentação & 0,436 \\
Alimentação no domicílio & 0,344 \\
Arroz & 0,016 \\
Feijão & $-0,024$ \\
Macarrão & 0,177 \\
Farinha de trigo & 0,118 \\
Açúcar e derivados & 0,370 \\
Legumes e Verduras & 0,326 \\
Frutas & 0,485 \\
Alimentos pré-preparados & 0,791 \\
Alimentação fora do domicílio & 0,745 \\
\hline
\end{tabular}

Fonte: Hoffmann (2000)

Essas propriedades proporcionaram, além do acréscimo na quantidade, modificação na característica da demanda por alimentos, em consequiência do aumento da renda ocorrida principalmente nos dois primeiros anos após a implantação do Plano Real. Observou-se, neste período, aumento de consumo de alimentos pré-prontos, frutas, verduras e legumes (Bertasso, 2000).

A redução da inflação também tornou possíveis diversas compras ao longo do mês, de acordo com a necessidade de cada família e sem queda substancial no valor real do salário. Isto reduziu o valor médio das compras, incrementou as compras por impulso, devido ao crescimento de frequiência de idas ao supermercado, mas aumentou a exigência por qualidade, resultado do aumento da comparação entre os produtos, e possibilitou a confrontação de preços entre lojas, pela estabilização dos preços (Como atrair..., 1995). A Tabela 14 resume as principais modificações do comportamento do consumidor após o plano econômico. 
Tabela 14. Modificações do comportamento do consumidor após a estabilização econômica.

\begin{tabular}{ll}
\hline Após estabilização econômica & Antes da estabilização econômica \\
\hline Vai mais vezes ao supermercado & Fazia compras mensais \\
Faz compras em menor quantidade & Abarrotava o carrinho \\
Exige mais qualidade & Pagava o que havia para não pagar mais depois \\
Maior fidelidade às marcas & Mudava de acordo com a oferta \\
\hline
\end{tabular}

Fonte: Como atrair... (1995, p.120)

No período de inflação muito alta, os consumidores, segundo Chiara (2002), tinham preferência pelo hipermercado, pois compravam em grandes volumes para estocar. Durante muito tempo, a expansão do setor ocorreu principalmente nesse segmento, porém, as dificuldades em encontrar terrenos em locais de fácil acesso e livres de concorrência estão favorecendo a abertura de lojas menores (Supermercado Moderno, 2000). Chiara (2002) acrescenta que as empresas médias souberam adaptar a oferta de produtos à sua clientela, além de oferecer serviços e comodidade.

Isso se refletiu no hábito de compra como apresentado por Rebouças (2002). Segundo a autora, os consumidores estão freqüentando mais as lojas de vizinhança e pequeno varejo, o que é revelado pelo aumento da participação no faturamento do setor das pequenas e médias lojas em 3,5 pontos percentuais entre 1999 e 2001. Segundo dados da ACNielsen, citados por Rebouças (2002), neste período, a participação no faturamento no varejo dos supermercados de vizinhança (classificado como lojas de 10 a 19 caixas) passou de 42,8\% para 43,7\%, enquanto o pequeno varejo alimentar (lojas de 1 a 9 caixas), cresceu de 12,8\% para $14,4 \%$ e a dos hipermercados/supermercados diminuíram de 18,2\% para 17,9\%. Essa tendência pode ser observada, também, pela Tabela 15, na qual se percebe o crescimento da participação das lojas com áreas entre $251 \mathrm{~m}^{2}$ e $2.500 \mathrm{~m}^{2}$ e estabilização das lojas acima de $5.000 \mathrm{~m}^{2}$. Este fato confirma a indicação da expansão das lojas de vizinhança e a estabilização do formato de hipermercados (Souza, 2002a). 
Tabela 15. Participação percentual dos formatos de loja entre 1999 e 2001 no Brasil.

\begin{tabular}{lrrr}
\hline Area de vendas & 1999 & 2000 & 2001 \\
\hline até $250 \mathrm{~m}^{2}$ & $23,8 \%$ & $21,1 \%$ & $16,9 \%$ \\
251 a $1.000 \mathrm{~m}^{2}$ & $37,3 \%$ & $37,8 \%$ & $40,6 \%$ \\
1.001 a $2.500 \mathrm{~m}^{2}$ & $26,1 \%$ & $26 \%$ & $27,6 \%$ \\
2.501 a $5.000 \mathrm{~m}^{2}$ & $7,6 \%$ & $8,9 \%$ & $8,6 \%$ \\
acima de $5.000 \mathrm{~m}^{2}$ & $5,3 \%$ & $6,2 \%$ & $6,3 \%$ \\
\hline
\end{tabular}

Fonte: Souza (2002a)

Nota: base: 3.579 lojas.

\subsubsection{Processo de concentração}

O processo de concentração do setor tornou-se mais evidente após o Plano Real. As grandes redes, buscando atuar nos diversos segmentos do setor, adquiriram outras redes. Segundo Sesso Filho (2001), as maiores redes centraram suas compras em redes de médio porte, geralmente familiares.

Para Silva \& Famá (1999), o aumento da concentração no setor está relacionado à redução da inflação, à automação do setor e à busca de ganhos de produtividade. A estabilização econômica, como mencionado anteriormente, diminuiu os ganhos financeiros do setor obrigando os supermercados a aumentarem as margens-objetivo de comercialização, como ficou evidenciado na Tabela 12, para manterem as margens de lucro. Porém, como se encontram em um ambiente competitivo, esses aumentos devem ocorrer mais pela melhora na eficiência do que pela elevação nos preços (Silva \& Famá, 1999).

A melhora na eficiência operacional, egundo os autores, baseoutse, entre outras ações, na automação das lojas, como observado na Figura 8. A implantação de tecnologias necessárias para se manter competitivo, requer investimentos e capacitação técnica dos funcionários, que, geralmente, os pequenos supermercados não têm condições de efetuar por falta de recursos. 
Silva \& Famá (1999) acrescentam que ganhos operacionais são obtidos também com fusões e aquisições através da economia de escala, sendo este um dos principais fatores para o aumento da concentração. Segundo os autores, esses ganhos são mais significativos quando a concentração geográfica de lojas for alta, por utilizar uma mesma estrutura de distribuição para atender um número maior de estabelecimentos.

\subsection{Organizações de compras}

Para Essig (2000), o estudo das relações externas das empresas é focalizado nas relações verticais com os principais fornecedores. A análise sobre cooperação horizontal entre compradores no mesmo nível da cadeia produtiva, segundo o autor, parece não ser área de grande interesse. Essig (2000) afirma que formas de cooperação e consórcio em compras foram primeiramente discutidas por Mitchell (1927) ${ }^{35}$ e Gushée \& Boffey $(1928)^{36}$ e a maioria dos trabalhos concentraram-se mais em cooperações no setor público.

O autor apresenta algumas formas de cooperação horizontal para negociações com os fornecedores, classificando-as de acordo com os termos anglo-americanos. Segundo o autor, quando ocorre cooperação entre firmas industriais independentes, denomina-se consortium purchasing (consórcio de compras), caso sejam integrantes de um grupo maior (subsidiárias de uma mesma empresa), chama-se de group purchasing (grupo de compras). No setor de varejo, as atividades cooperativas são denominadas de buying offices (escritórios de compras). $\mathrm{O}$ termo cooperative purchasing (cooperativa de compras) é utilizado para as cooperações do setor público. E, finalmente, pooled purchasing (associação de compras) ocorre com a união de empresas de diversos setores. Entretanto, o autor ressalta que essas denominações não são utilizadas de forma uniforme (Essig, 2000).

\footnotetext{
35 MITCHELL, W.N. Purchasing. New York, 1927.

${ }^{36}$ GUSHÉE, E.T.; BOFFEY, L.F. Scientific purchasing. New York: McGraw-Hill, 1928.
} 
Leenders \& Fearon (1997), por exemplo, não utilizam esta classificação e apresentam apenas o purchasing consortium (consórcio de compras) e cooperative purchasing (cooperativas de compras). Neste caso, o segundo é um caso do primeiro.

Segundo os autores, os consórcios são comuns em organizações sem fins lucrativos, mas estão começando a interessar à iniciativa privada que visa lucro. Nos consórcios, as organizações consolidam suas demandas para alavancar vantagens com os fornecedores. Os autores apontam como as principais contribuições do consórcio: a redução de preços; a melhora na qualidade através de testes e seleção de fornecedores; a redução nos custos administrativos; o compartilhamento dos conhecimentos do mercado; a padronização e o aumento na rivalidade (Leenders \& Fearon, 1997).

Um consócio pode ser formado por qualquer grupo cujos membros possuam demandas iguais e que podem realizar compras conjuntas. As operações do consórcio são, segundo os atores, normalmente simples e ocorrem geralmente da seguinte forma (Leenders \& Fearon, 1997, p.69):

- uma terceira parte realiza as funções administrativas e de negociação em nome dos membros do consórcio. Estes membros passam os pedidos e supervisam diretamente o terceiro;

- a terceira parte permanece neutra financeiramente em relação aos membros do consórcio. Cada membro deve pagar ao consórcio em um prazo adequado para que este possa quitar as faturas decorrentes das compras conjuntas;

- a terceira parte recebe uma taxa para cobrir todas as despesas do serviço de compras;

- os preços pagos pelo consórcio nunca são divulgados.

Os autores apontam, ainda, a possibilidade de intervenção governamental restringindo o negócio devido às leis antitruste nos EUA. Entretanto, não há violação destas leis, no caso americano, se as compras por consórcio forem menores do que $25 \%$ das vendas totais do produto ou serviço comercializado no mercado relevante e se os custos dos produtos ou serviços comprados conjuntamente forem menores do que $10 \%$ 
da receita total advinda de todos os produtos e serviços vendidos por cada membro do consórcio (Leenders \& Fearon, 1997).

Em relação ao mercado brasileiro, a defesa da concorrência é regulamentada pela Lei No. 8.884, de 11 de junho de 1994, que transforma o Conselho Administrativo de Defesa Econômica - CADE em autarquia e dispõe sobre a prevenção e a repressão às infrações conta a ordem econômica, entre outras providências. Em seu artigo 20, são apresentadas as infrações à ordem econômica, que podem consistir em (i) prejudicar de alguma forma a livre concorrência ou a livre iniciativa, (ii) dominar o mercado relevante de bens e serviços, (iii) aumentar arbitrariamente os lucros, ou (iv) exercer de forma abusiva a posição dominante. Segundo esta lei, a posição dominante ocorre quando uma empresa ou grupo de empresas controla parte substancial do mercado relevante, presumida sendo da ordem de $30 \%$, como fornecedor, intermediário, adquirente ou financiador de um produto, serviço ou tecnologia.

Essig (2000) relaciona cada forma de consórcio com o grau de independência entre os membros e a formalidade da cooperação com cada área de atividade dos participantes. $\mathrm{O}$ autor explica que em cooperações com membros altamente independentes não há correlação positiva (por exemplo, divisão do grupo) nem negativa (como rivalidade) entre os participantes. Em cooperações altamente formalizadas ocorre uma joint venture na qual os membros comprometem-se financeiramente. Observa-se por este modelo (Figura 9) que, no varejo, a cooperação é altamente formalizada, ou seja, com comprometimento financeiro, e não importa o grau de independência entre seus participantes. 


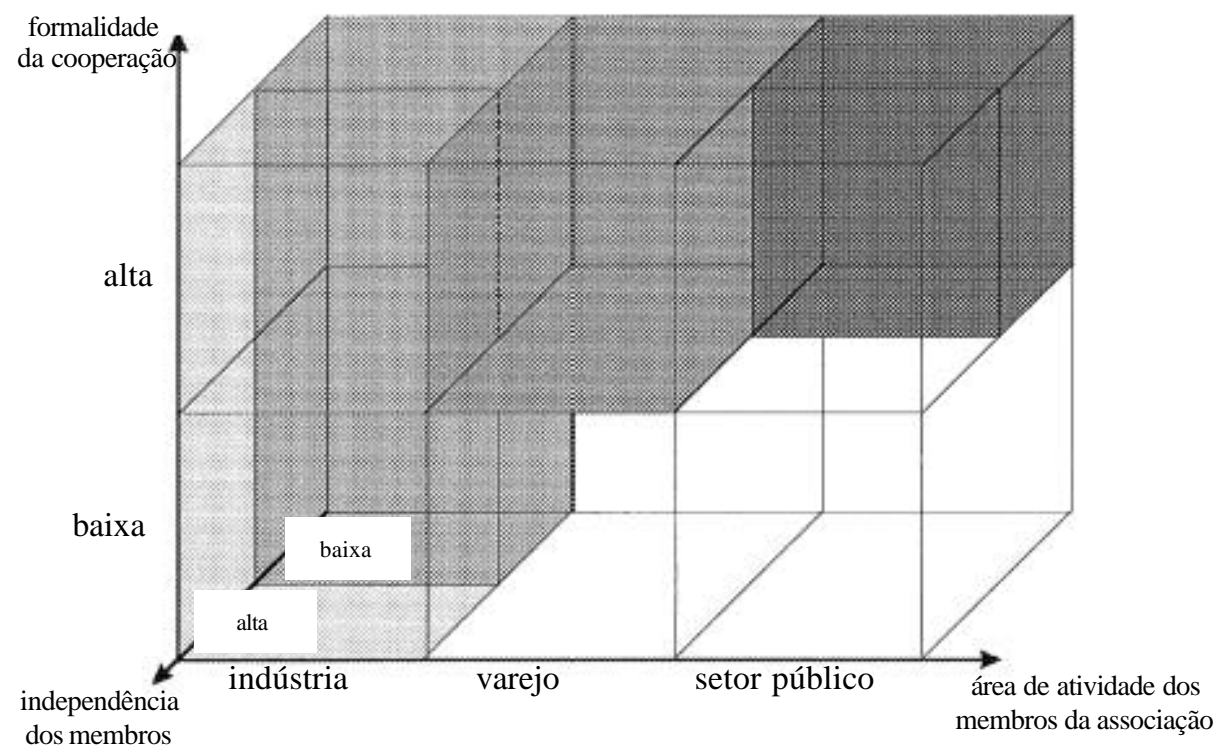

Figura 9 - Modelo de Termos Anglo-americano para cooperações horizontais.

Fonte: Essig (2000, p.14)

Legenda:

\begin{tabular}{|ll|}
\hline & Consortium purchasing (Consórcio de compras) \\
\hline & Group purchasing (Grupo de compras) \\
\hline & Buying office (Escritório de compras) \\
\hline & Cooperative purchasing (Cooperativa de compras) \\
\hline
\end{tabular}

Segundo Essig (2000), as "cooperativas de compras", referentes ao setor público, são populares nos Estados Unidos. A E\&I Cooperative Service é uma das maiores e mais antigas cooperativas do setor público representando mais de 2000 universidades, colégios e hospitais. Existem, também, mais de 100 cooperativas na área de seguro de 
saúde nos Estados Unidos. Leenders \& Fearon (1997) citam também o caso das três maiores cooperativas norte-americanas de hospitais que formam a Premier Inc. que negocia o fornecimento de materiais para mais de 1.700 hospitais e obtém economias de 20 a $30 \%$ em alguns casos.

Para Leenders \& Fearon (1997), existem duas principais variações nas cooperativas de compras: a compra em conjunto e o arranjo contratual. No primeiro, dois ou mais, departamentos de compras concordam em juntar suas demandas por um determinado item e escolhem um destes departamentos para realizar a negociação e a compra para todos os outros departamentos. $\mathrm{O}$ arranjo contratual ocorre quando alguns departamentos de compras concordam em estabelecer uma agência cooperativa de compra e se comprometem a usar os serviços desta agência. Neste último caso, os gastos administrativos de agência cooperativa são rateados entre os membros sob algum critério, como o tamanho dos participantes ou o volume total negociado através da agência (Leenders \& Fearon, 1997).

Apesar do trabalho de Essig (2000) ser voltado ao "consórcio de compras", ou seja, cooperações entre indústrias independentes, muitos dos conceitos apresentados servem igualmente para o setor varejista. $\mathrm{O}$ autor afirma que para haver este tipo de estratégia de compras, os membros da organização devem estabelecer uma estrutura cooperativa, que, na sua opinião, deve ser simbiótica: as companhias devem pertencer ao mesmo estágio da cadeia produtiva e combinar de forma conjunta os volumes a serem negociados.

Essig (2000) caracteriza uma simbiose como uma relação na qual há criação de valor para ambos os parceiros. Segundo o autor, o "consórcio de compras" é uma relação simbiótica pois ajuda a reduzir os custos de transação por diminuir o volume de operações e por formar uma nova estrutura de governança. Seguindo o exemplo do autor, sem o consórcio, quatro empresas comprando dos mesmos três fornecedores realizam $(4 \times 3=) 12$ transações de compras. Com a compra conjunta, necessita-se de apenas $(4+3=) 7$ transações, como se pode observar pela Figura 10. 
Sem Consórcio

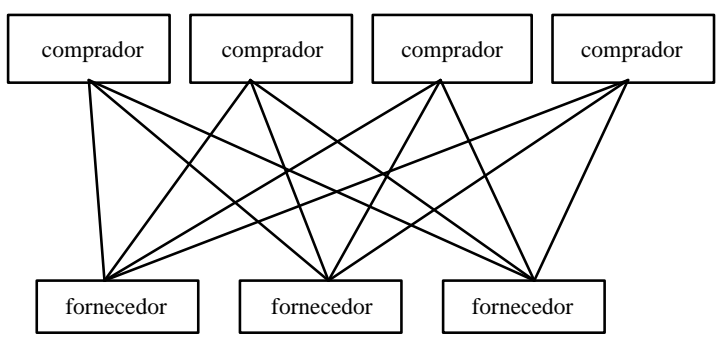

Com Consórcio

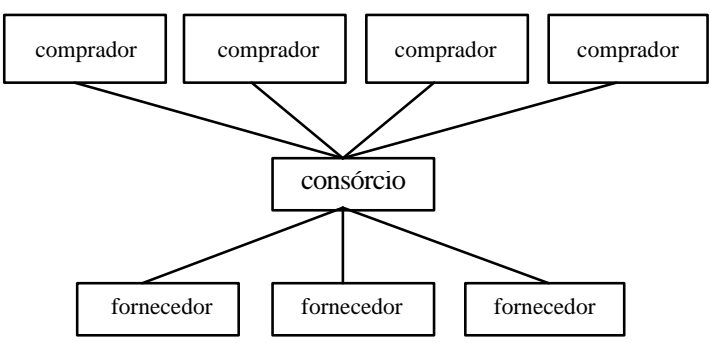

Figura 10 - Comparação entre volume de transações necessárias com e sem consórcio.

Fonte: Baseado em Essig (2000), adaptado pelo autor.

Nota: Cada linha representa uma transação.

Para Williamson $(1985,1991)^{37}$, citado por Essig (2000), este tipo de cooperação forma uma instituição híbrida que combina a estrutura hierárquica com a de mercado, pois os membros permanecem como companhias separadas, mas combinam seus poderes de compra. Desta forma, para Essig (2000), relações simbióticas são sempre instituições híbridas.

O "consórcio", ainda, possibilita dividir os benefícios comuns entre seus membros, por reduzir seus preços de compra e utilizar melhor os funcionários da área de suprimento. A economia de escala nas compra, decorrente do consórcio, permite, também, melhorar a situação no mercado de suprimentos de cada firma (Essig, 2000).

37 WILLIAMSON, O.E. The economic institutions of capitalism: firms, markets relational contracting. New York: Free Press, 1985.

WILLIAMSON, O.E. Comparative economic organization: the analysis of discrete structural alternatives. Berkeley: University of California, 1991. (Working Paper) 


\section{METODOLOGIA}

\subsection{Estudo de Casos}

Yin (1990) afirma que a metodologia de estudo de casos é indicada quando o pesquisador propõe-se responder as questões "como" e "porquê", tem pouco ou nenhum controle sobre o evento em estudo e é um fenômeno contemporâneo inserido no contexto na vida real. Conforme Lazzarini (1997), esse é um método qualitativo que se caracteriza mais pela compreensão do fato do que pela sua mensuração e possibilita utilizar várias fontes de evidências. Para o autor, o estudo de caso aparece como "um método de pesquisa hábil e sensível em analisar um fenômeno dentro do seu contexto mais amplo, em situações onde esta inserção traga reais benefícios à pesquisa" (Lazzarini, 1997, p.14).

Segundo Yin (1990), o passo seguinte à escolha da metodologia é o planejamento da pesquisa. Para o estudo de casos, cinco componentes são especialmente importantes para o planejamento: (i) as questões de estudo; (ii) suas proposições, se existirem; (iii) suas unidade(s) de análise; (iv) as ligações lógicas entre os dados e as proposições; (v) e o critério de interpretação dos resultados (Yin, 1990, p.29).

Lazzarini (1997) explica que, em função das unidades de análise, do número de casos utilizados e dos métodos empregados conjuntamente, existem algumas variações no escopo da pesquisa baseada em estudo de caso. A unidade de análise, segundo o autor, é objeto central da pesquisa e pode ser caracterizada por indivíduos, grupos, organização, bem como um processo, uma atividade, um aspecto ou dimensão do comportamento organizacional ou social. 
Yin (1990) diferencia, ainda, o estudo de caso dependendo do número de unidades de análise. Quando o foco principal do trabalho concentra-se num contexto global do fenômeno, tem-se um estudo de caso holístico. Porém, quando a unidade de análise possui subunidades, nas quais se estuda os diferentes aspectos do objeto divididos em tópicos (cada um visto como um caso) e que se inserem num contexto mais amplo, tem-se um estudo de caso embutido (embedded). O estudo de caso holístico é indicado quando nenhuma subunidade lógica é identificada ou quando a teoria utilizada é de natureza holística. Porém, este caso permite que um pesquisador evite a análise de algum fenômeno específico, podendo criar problemas de análise. A principal dificuldade no estudo de caso embutido ocorre quando se focaliza o estudo apenas no nível das subunidades, esquecendo-se da unidade principal do trabalho (Yin, 1990).

Em relação ao número de casos, conforme Lazzarini (1997), o estudo pode ser singular ou múltiplo. No primeiro, concentra-se apenas em um caso para dado problema e referencial teórico. É utilizado para análise de fenômenos raros ou de difícil observação e pode ser empregado para o desenvolvimento de teorias (Yin, 1990).

O estudo de casos múltiplo considera repetições de um fenômeno, mas sem necessariamente ter uma lógica de amostragem como ocorre em outros métodos. A vantagem desse método é proporcionar evidências presentes em diversos contextos, tornando a pesquisa mais robusta (Lazzarini, 1997). Yin (1990) acrescenta, porém, que a realização do estudo de casos múltiplos pode requerer mais tempo e recursos do que o estudo de caso único.

Os estudos de casos singulares ou múltiplos são subdivididos em holísticos ou embutidos dependendo da existência de subunidades de análise envolvidos na pesquisa.

Esta metodologia, portanto, é particularmente aplicável quando se pretende obter generalizações analíticas, e não estatísticas, buscando contribuir para um referencial teórico sem o qual o trabalho acaba tornando-se uma mera descrição do objeto de estudo (Lazzarini, 1997). Segundo Yin (1990), as principais limitações, entretanto, são a subjetividade da análise, impossibilidade de generalização das conclusões. 


\subsection{Desenvolvimento da pesquisa}

O surgimento de associações de pequenos supermercados ou redes independentes não é um fenômeno recente. Porém, está tornando-se uma estratégia importante para a sobrevivência destas empresas nos últimos anos. Em vista das modificações que ocorrem no setor supermercadistas surge, contudo, a questão de como e por que a formação dessas associações é um recurso para a sobrevivência destes varejistas.

Para buscar uma resposta a essa questão, primeiramente procurou-se contextualizar o processo de concentração do setor supermercadista e suas consequiências nas relações verticais, utilizando as teorias da Organização Industrial e Economia dos Custos de Transação, e o reflexo desse processo nos pequenos supermercados. Posteriormente, verificaram-se quais as atividades das associações, os benefícios e encargos aos associados para analisar se são uma alternativa de estrutura de governança, utilizando-se também da Economia dos Custos de Transação e da Ação Coletiva.

Porém, devido à natureza do objeto de estudo - tem-se nenhum controle sobre o evento que é contemporâneo e está inserido no contexto da vida real - e do problema, optou-se pela utilização do estudo de casos como metodologia. Os objetos de análise escolhidos para a observação deste fenômeno foram as associações de supermercados das cidades de Limeira e Piracicaba, sendo, portanto, um estudo de caso múltiplo e holístico.

Com o propósito de descrever sucintamente a estrutura do setor supermercadista brasileiro utilizou-se a análise de concentração e apontaram-se as principais barreiras de entrada e saída das empresas no setor citadas por estudos. Para a percepção do grau de concentração do setor de auto-serviço no país, pode-se adotar dois índices: (i) razão de 
concentração $\left(\mathrm{C}_{\mathrm{n}}\right)^{38} \mathrm{e}$ (ii) índice de Hirschman-Herfindahl $(\mathrm{HHI})^{39}$.

Os principais problemas deste índice, segundo Marques (1992), são que não mostram o número de empresas não contempladas (n-r) no cálculo do $\mathrm{C}$ (porém isso pode ser contornado indicando a porcentagem que as $\mathrm{r}$ empresas representam do total) e o índice permanece inalterado quando ocorrem fusões, aquisições etc. entre as (n-r) empresas. Além disso, não apresenta as desigualdades entre as empresas.

O índice de Hirschman-Herfindahl (HHI) varia de $1 / n$ (onde $n$ é ó número de empresas) a 1.Quando a indústria possui apenas uma firma (monopólio) o índice possui valor 1. Este valor diminui conforme aumenta o número de empresas, e aumenta com a elevação da desigualdade entre qualquer número de firmas. Assim, possui correlação entre o número de empresas e a desigualdade em que o mercado está distribuído (Scherer, 1970). Desta forma o índice capta não só a concentração, mas também a distribuição da participação das empresas no mercado.

Pelo fato do índice elevar ao quadrado a participação individual das firmas faz com que as empresas grandes possuam maior peso do que as pequenas. Desta forma, imprecisões relacionadas às medidas das firmas menores resultam em erros pequenos. Porém, exige maior exatidão no cálculo da participação das grandes firmas. Este índice aumenta conforme a iniqüidade cresce e diminui com o incremento do número de empresas (Scherer \& Ross, 1990). Atualmente, as pesquisas utilizam na estimativa desse

$$
{ }^{38} \mathrm{C}_{r}=100 \sum_{i=n-r+1}^{n} S_{i}
$$

Onde, considerando as empresas classificadas em ordem crescennte de participação no mercado, $S_{i}$ representa a participação em alguma variável indicativa do tamanho do mercado (venda, lucro receita total, número de empregados etc.) da igésima empresa, $n$ é o número de empresas estudadas (inclui-se na categoria outros o resíduo que não foi descriminado) e $r$, o número de empresas a serem consideradas no cálculo (costuma-se considerar em estudos os valores de 4,8 ou 16).

${ }^{39} H H I=\sum_{i=1}^{n} S_{i}^{2}$

Onde $S_{i}$ é igualmente a participação decimal do mercado da igésima firma. 
índice valores percentuais. Deste modo, o índice de Hirschman-Herfindal varia de 10.000/n a 10.000. Contudo, a análise dos resultados permanece a mesma. A principal desvantagem, segundo Scherer (1970), deste índice é a dificuldade em se obter dados abrangentes da participação do mercado requerida para o seu cálculo.

A variável mais utilizada na literatura para apontar o grau concentração no setor supermercadista é a receita bruta das redes. A ABRAS divulga anualmente um rank das 300 maiores redes no país.

Em relação à conduta das empresas, foram apresentadas as principais modificações do setor enquanto tecnologias adotadas, estratégias de compra, venda e crescimento. Quanto ao desempenho, são apresentados dados sobre margens de comercialização praticadas por supermercados e alguns índices de eficiência (relação entre empregados por lojas, faturamento por loja, faturamento por empregado, empregados por área e faturamento por área).

O ferramental da Organização Industrial é utilizado, portanto, para analisar o setor supermercadista e sua modificação nos últimos anos. Enquanto a Economia dos Custos de Transação contribui para explicar alguns motivos que levaram a essa modificação no setor e a possibilidade das associações serem uma estratégia para os pequenos supermercados adaptarem-se ao novo ambiente. A Ação Coletiva é utilizada para compreender a formação das associações, suas vantagens, limitações e desafios.

Para exemplificar esse processo foram utilizadas duas associações existentes nas cidades de Piracicaba e Limeira. O estudo serviu-se de informações obtidas através de entrevistas pessoais com os dirigentes das associações, seguindo um roteiro (apresentado no apêndice 1) para reduzir a subjetividade da análise, e um questionário (constante no apêndice 2) para os associados.

As entrevistas visaram obter informações sobre a história da associação, seus objetivos, sua organização, sua forma de funcionamento, suas estratégias etc, como se pode observar no roteiro citado. Com o questionário, buscourse identificar as principais 
características dos supermercados associados e as mudanças que ocorreram com os mesmos. Também, tratar dos principais fatores que motivaram a participação na associação, os serviços prestados por ela e o grau de satisfação em relação a esses serviços.

Para tanto, o questionário é dividido em duas partes. A primeira caracteriza o supermercado questionando sobre (i) tamanho, (ii) número de itens vendidos, (iii) número de caixas, (iv) faturamento bruto, (v) utilização de meio de divulgação (jornais, $\mathrm{TV}$, rádio, outdoor etc.), (vi) existência de serviços (programa de fidelidade, marca própria, estacionamento, etc.), (vii) treinamento de funcionário. Ainda neste item é perguntado sobre o ambiente em que atua as lojas, como distância do principal concorrente.

A segunda parte do questionário aborda (i) os serviços prestados pela associação e qual o grau de satisfação, (ii) a participação dos itens fornecidos pela associação no mix da loja, (iii) a diminuição nos custos de aquisição dos produtos, (iv) o aumento médio no faturamento, (v) algumas mudanças após o início das atividades na associação (redução no número de funcionários e estoques, melhora na qualidade dos produtos e no atendimento etc.) e (vi) as razões que levaram os supermercados a se associarem.

A primeira parte do questionário acima descrito foi baseado em outro questionário utilizado pelo "The Retail Food Industriy Center" da Universidade de Minissota, EUA, para a realização de um painel sobre supermercados norte-americanos. E a segunda parte foi realizado para captar os serviços e vantagens das associações.

A partir das informações obtidas com as entrevistas e questionários, pôde-se analisar as associações à luz da Ação Coletiva e verificar se elas são uma estratégia adequada para tornarem-se mais competitivas, através da análise da Economia dos Custos de Transação. 


\section{RESULTADOS E DISCUSSÃO}

Na busca de uma resposta à questão de "como" as associações podem ser uma estratégia de melhora na competitividade de pequenos supermercados e redes independentes, foram analisadas duas das três associações que existem na região de Piracicaba, pois a terceira não quis participar da pesquisa.

A análise do setor, utilizando o paradigma da estrutura-conduta-desempenho, procura explicar o "porquê" da formação das associações, ou seja, quais os fatores que levaram os supermercados a se unirem em torno destas organizações.

O presente capítulo foi dividido em 4 itens. O primeiro apresenta o ambiente em que as associações se inserem e como esse ambiente relaciona-se com a formação das associações; o segundo descreve as associações estudadas e os principais resultados obtidos com os supermercados pesquisados. O item seguinte relaciona as redes em estudo com a Economia dos Custos de Transação, o quarto item, com a teoria da Ação Coletiva.

\subsection{Relação entre estrutura, conduta e desempenho para o setor supermercadista}

Neste item, pretende-se apresentar o setor supermercadista sob o enfoque do paradigma da estrutura-conduta-desempenho, seguindo o esquema ilustrado pela Figura 1. Focaliza-se, inicialmente, as condições básicas do setor, que influenciam e são influenciadas pela estrutura do mercado, que, por sua vez, relaciona-se com a conduta das empresas nesse setor. Apresenta-se, também, o desempenho que está pautado na conduta das empresas. E, finalmente, as políticas públicas que influenciam todos os aspectos. 


\subsubsection{Condições básicas}

Para a análise das condições básicas do setor, deve-se observar que o serviço oferecido pelo supermercado consiste, principalmente, em disponibilizar uma variedade grande de itens em apenas um local, proporcionando comodidade, praticidade e economia de tempo para o consumidor. Esta atividade possui uma característica de presença local, ou seja, área de atuação das firmas está diretamente ligada à presença de lojas que têm uma ação geográfica limitada, como visto no capítulo 4.

No setor, existem consideráveis economias de escala, principalmente logísticas, que são mais evidentes quando há maior concentração geográfica de lojas. Pode-se encontrar, ainda, economias de escala nas promoções, nas compras, nos financiamentos, nas operações, entre outros, que resultam em vantagens competitivas às grandes redes.

A tecnologia e a mão de obra empregadas no setor são pouco específicas. Contudo, existe uma tendência de aumento na qualificação dos trabalhadores, buscado melhora na qualidade dos serviços prestados aos clientes e na automatização do processo operacional, visando redução nos custos e aumento na eficiência. $\mathrm{O}$ uso de tecnologias mais robustas como, por exemplo, o EDI, entretanto, é caro e seu retorno não é imediato, o que limita seu uso pelas empresas menores, influenciando seu desempenho.

A demanda pelos consumidores por quantidade, qualidade e variedade é influenciada principalmente pela renda. No Brasil, o aumento de renda gera crescimento no consumo de produtos alimentícios, como calculado por Hoffmann (2000) no estudo de elasticidade-renda. Como o item "alimentos" participa com $68 \%$ do faturamento das lojas, segundo Souza (2002b), a elevação de renda gera aumento no faturamento do setor. As exigências da demanda por preço e qualidade aumentaram com a redução nas taxas de inflação causadas pela possibilidade de comparação de preços, pelo aumento na frequiência das compras e pela elevação na renda da população. Outro fator relacionado positivamente, porém menos significativo, é o crescimento da população.

O hábito de compra atualmente é caracterizado por compras freqüentes e com 
valores médios menores do que ocorria no período de inflação alta. O consumo também tem peculiaridades regionais que devem ser atendidas pelas lojas, favorecendo as empresas que possuem melhor conhecimento sobre seu público.

\subsubsection{Estrutura de mercado}

O setor supermercadista éformado por um grande número de pequenas empresas presentes em todo o país, bem como por um grupo pequeno de grandes redes que, a partir da década de 90, começaram a ampliar sua área de atuação de um nível regional para nacional. Observando-se a Tabela 16, percebe-se que a maior concentração do setor encontra-se entre as duas maiores empresas, que juntas possuíam, em 2001, mais de um quarto da receita bruta do setor. À medida que se incluem mais empresas, a taxa de aumento do índice é menor. A expansão do índice entre as duas e as quatro maiores empresas é de 9,2 pontos percentuais, enquanto as oito maiores possuem apenas 8,2 p.p. a mais. Ao juntar-se outras oito empresas, totalizando 16, tem-se um aumento de 5,8 p.p.

Tabela 16. Concentração do setor supermercadista brasileiro em 2001.

\begin{tabular}{lcccc}
\hline Indices de concentração & $\mathrm{C}_{2}$ & $\mathrm{C}_{4}$ & $\mathrm{C}_{8}$ & $\mathrm{C}_{16}$ \\
\hline Participação (\% do faturamento) & $26,3 \%$ & $35,5 \%$ & $43,7 \%$ & $49,5 \%$ \\
\hline
\end{tabular}
Fonte: ABRAS (2002), cálculo do autor.

Estas características apontam para uma estrutura em que existem algumas empresas líderes, com grande participação no mercado, e um grande número de pequenas empresas, constituindo uma franja, uma vez que no Brasil existiam cerca de 10.000 empresas de supermercados e hipermercados em 2000, segundo dados divulgados pelo IBGE (2002). Além disso, como setor possui economias de escala, espera-se que as empresas líderes, ou seja, pertencentes ao oligopólio, tenham custos menores do que a franja. Neste caso, o resultado deve ser semelhante ao encontrado no item 2.1, no qual as empresa dominantes possuem custos menores. A franja é composta por um número grande de firmas e, como apontado por Ferreira (2002) no caso do setor 
supermercadista, a entrada é livre e "tempestiva". Cyrillo (1987) acrescenta que o oligopólio busca diferencia-se, sendo classificado pela autora como oligopólio diferenciado com franja, como já mencionado.

Ao observar a variação da concentração ao longo do tempo, percebe-se o aumento nos seus indicadores. As diferenças entre os índices $C_{4}$ e $C_{8}$ apontam que o aumento de concentração não se deu apenas com as quatro maiores empresas mas também entre as outras quatro firmas que participam do cálculo do índice C8. Porém, comparado com a razão de concentração de outros países, como visto no item 3.1.1.1, estes índices são considerados baixos.

A mesma tendência de aumento ocorre com o HHI (Tabela 17). Este índice inclui a participação das 300 maiores empresas, apresentadas pela ABRAS (2002), e utiliza apenas a receita bruta destas firmas. A elevação do HHI denota que, mesmo com o aumento do número de empresas do setor (apresentada na Tabela 9), que reduz o valor do índice, a desigualdade entre as firmas do setor aumentou, ou seja, a diferença entre a receita bruta das grandes empresas e as pequenas cresceu.

Tabela 17. Indicadores de concentração no setor supermercadista no Brasil.

\begin{tabular}{lccc}
\hline Índice & 1995 & 1998 & 2001 \\
\hline Hirschman-Herfindahl (HHI) ${ }^{(*)}$ & 239 & 312 & 416 \\
$\mathrm{C}_{4}$ & $25,50 \%$ & $30,26 \%$ & $35,49 \%$ \\
$\mathrm{C}_{8}$ & $31,90 \%$ & $37,57 \%$ & $43,75 \%$ \\
\hline
\end{tabular}

Fonte: ABRAS (2002), cálculo do autor.

Nota: Utilizourse a receita bruta das empresas para o cálculo dos índices.

(*)Para as 300 maiores empresas.

Com a propensão de maior eqüidade entre as pequenas empresas em relação às grandes, espera-se que o HHI possua valores menores para todo o setor do que os números apresentados na Tabela 17, referentes às 300 maiores empresas. Contudo, devese ter ciência que os dados são nacionais e que, quando calculados para regiões mais específicas, os valores tendem a ser maiores, como apresentado por Cavalcante et al. 
(2001a, 2001b).

As participações percentuais do faturamento bruto, de check-outs, de área de vendas, de lojas e de funcionários das quatro e oito maiores empresas supermercadistas em faturamento em relação ao total do setor, são apresentadas na Figura 11. Observa-se que estas empresas, apesar de possuírem grande parte do faturamento do setor, têm uma participação pequena no número de lojas, apenas 1,37\% para as quatro maiores e 1,64\% para as oito maiores, porém, maior com relação à área de venda, que corresponde a $17,25 \%$ e $21,13 \%$ respectivamente, indicando que possuem lojas maiores. A menor participação, também, no número de funcionários e de check-outs em relação ao faturamento, mostra maior eficiência por estas empresas, pois com menor estrutura, as grandes redes conseguem maior faturamento.

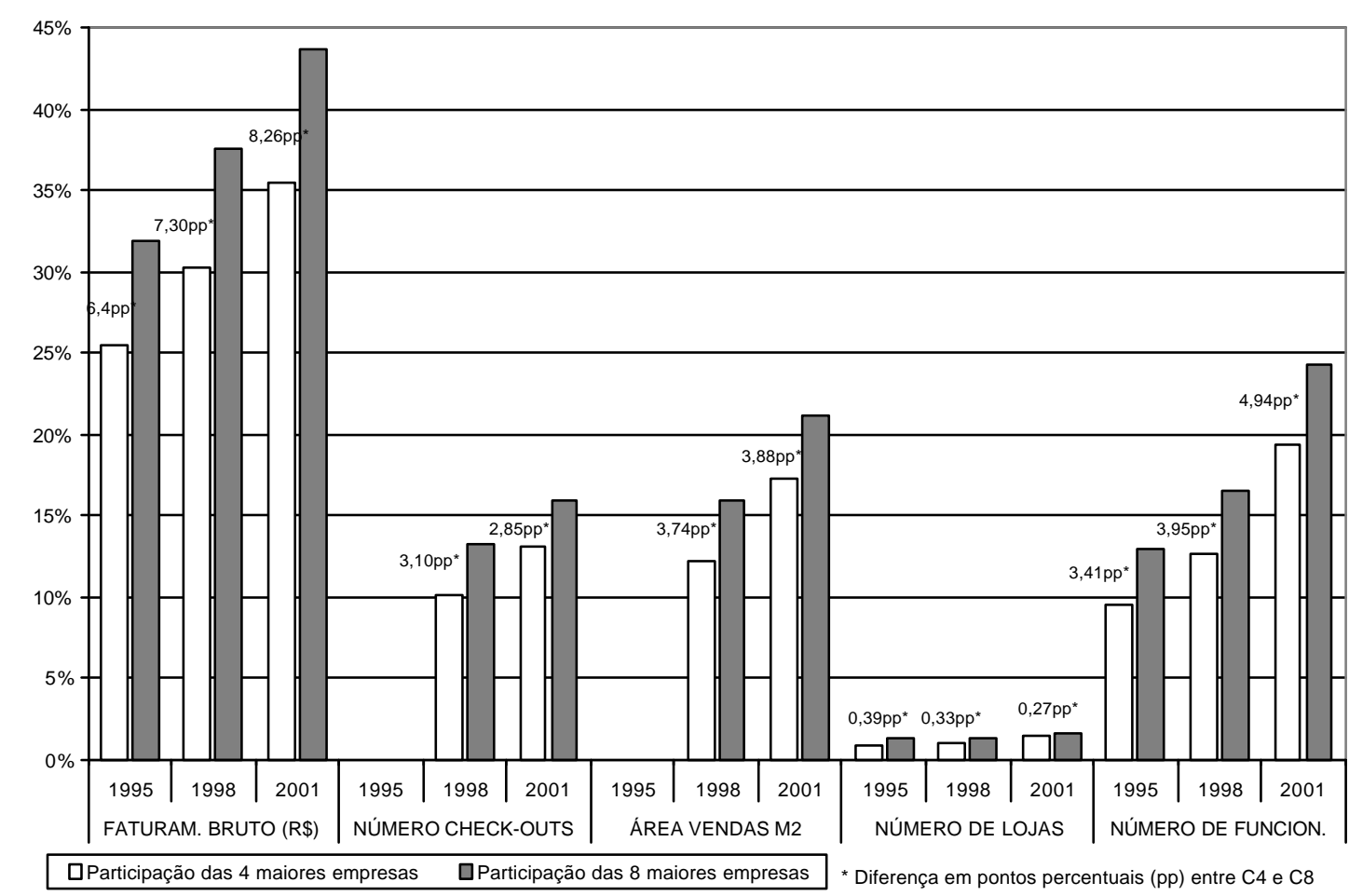

Figura 11 - Participação percentual das quatro e oito maiores empresas em faturamento bruto algumas variáveis do setor.

Fonte: ABRAS (2002), elaboração do autor. 
Pela Figura 11, fica evidente o amento de participação tanto das quatro, quanto das oito maiores empresas em todos os itens apresentados. Apenas com exceção do item número de lojas, a diferença em pontos percentuais entre as quatro e oito maiores empresas em faturamento também cresceu, indicando que o avanço da participação também ocorre entre as oito maiores empresas e não somente entre as quatro primeiras. Com relação ao número de lojas, a redução na diferença entre os índices $\mathrm{C}_{4}$ e $\mathrm{C}_{8}$ aponta para um investimento maior em abertura e aquisição de novas lojas entre as quatro maiores empresas em relação às demais firmas integrantes do índice.

As barreiras à entrada de novas firmas no setor, como visto no item 3.1.4, são consideradas baixas por, entre outras razões, poderem ser contornadas através de aquisições ou fusões. As principais barreiras que se mantêm mesmo com essa estratégia são as economias de escala e gastos com publicidade, que incentivam a adoção de estratégias de crescimento das empresas.

Com relação aos fornecedores, o setor depara-se com uma grande heterogeneidade, em razão da variedade de produtos comercializados. Os supermercados têm desde grandes fornecedores, com marcas fortes, até pequenas empresas de atuação regional. Isto, juntamente com os hábitos de consumo, o ambiente institucional (como leis e impostos), o tamanho e a política de compra do supermercado, influencia a relação com os fornecedores.

As grandes indústrias, por exemplo, durante a década de 80 , focavam sua venda direta às grandes redes de supermercado, deixando os pequenos varejistas ao encargo dos distribuidores e atacadistas. Porém, com o aumento do poder de negociação das grandes redes, essas indústrias mudaram de estratégia e começaram a atender as redes médias e também pequenas com as quais têm maior poder de barganha, reduzindo a importância dos atacadistas.

Os atacadistas, percebendo esta alteração na estratégia das indústrias, começaram a realizar parceiras com o varejo, como, por exemplo, através redes como a IGA (de 16 empresas de distribuição) e a Rede Smart (do Grupo Martins de Uberlândia). Nestas 
parcerias, além de oferecer os produtos tradicionais, disponibilizam serviços de soluções de marketing, operacionais etc., procurando fidelizar seus clientes (os supermercados). Nestes casos, há uma situação de restrição vertical, caracterizado por um contrato entre o varejista e o atacadista que especifica a forma de comportamento de ambos, porém sem o controle total de uma firma sobre a outra.

A existência de economia de escala nas compras, como apresentado no item 3.1.5, reforça a tendência de concentração no setor causada pela maior eficiência de grandes redes. Essa economia incentiva as grandes cadeias de supermercados a adotarem uma conduta de centralização de compra e expansão que possibilite aumento no volume e freqüência das aquisições. Estes aumentos, segundo a Economia dos Custos de Transação, permitem; (i) a diluição dos custos de adoção de mecanismos mais complexos de transação, como uso de automação nos sistemas de pedidos e elaboração de contratos com os fornecedores (custos ex-ante), (ii) a construção de reputação por parte dos agentes envolvidos e (iii) a redução de ações oportunistas, devido à importância do cliente. Os dois últimos diminuem os custos com monitoramento (custos ex-post) e incentivam os agentes a realizarem as transações dentro do contrato, o que reduz a incerteza do negócio e atenua, portanto, ainda mais os custos de transação.

O aumento do volume comercializado possibilita, igualmente, o aumento de poder de barganha que ocorre principalmente por dois motivos; (i) o cliente torna-se importante meio de comercialização da indústria, visto que atualmente mais de $85 \%$ do volume de vendas de produtos de consumo diário são realizados pelos supermercados e (ii) a redução dos custos de transação.

Assim, as características da estrutura de mercado do setor supermercadista beneficiam principalmente as grandes empresas.

\subsubsection{Conduta}

As economias de escala e as baixas barreiras à entrada do setor encorajam as empresas a investirem na sua expansão, sendo esta uma das causas do aumento da 
concentração no setor. Além disso, como a atuação das empresas é local, o crescimento dá-se principalmente pelo aumento do número de lojas, seja através de construção de novas lojas ou aquisição das existentes.

O ganho com a economia de escala em logística justificou o caráter de ação regional das grandes redes até a primeira metade da década de 90. Porém, a busca de outros ganhos e o desenvolvimento de tecnologias de informação conduziram as redes a expandirem-se para outras regiões.

A principal estratégia adotada para a expansão é a aquisição ou fusão, pois contorna as principais barreiras à entrada, visto que obtêm a estrutura e o conhecimento dos supermercados existentes. Esta foi a forma pela qual as firmas estrangeiras, que entraram no mercado brasileiro a partir do final da década de 80, iniciaram suas atividades no país, sobretudo, ao adquirirem grandes redes regionais. Posteriormente, essas empresas começaram a comprar também redes de porte médio. Como se pode observar pela Tabela 18, a partir de 1997 este processo acelerou-se chegando ao auge em 1999.

Tabela 18. Número de fusões e aquisições no setor supermercadista ${ }^{40}$.

\begin{tabular}{lcccccccccc}
\hline & 1994 & 1995 & 1996 & 1997 & 1998 & 1999 & 2000 & 2001 & 2002 \\
\hline Número de fusões e aquisições & 2 & 1 & 2 & 9 & 13 & 24 & 10 & 8 & 1 \\
\hline Fonte: KPMG (2002) & & & & & & & & & \\
* Primeiro semestre. & & & & & & & & & &
\end{tabular}

Os supermercados também procuram criar parcerias com alguns fornecedores, seja através de troca de informações, ou pelas realizações de promoções, ou desenvolvimento de produtos entre outros. Quando possível, algumas redes ainda criam programas de fidelidade com eles, na qual o varejista compromete-se a adquirir os

\footnotetext{
${ }^{40}$ Os valores apresentados são referentes às fusões e aquisições divulgadas pela mídia.
} 
produtos por um período de tempo e os fornecedores pagam uma taxa por isso. Ou seja, o fornecedor tem reduzido sua incerteza, o que, segundo Williamson (1987), reduz os custos de transação. Os supermercados, portanto, buscam ficar com uma fatia desta economia.

As características da estrutura do setor (entrada com baixas barreiras e "tempestiva" e presença de uma franja) também limitam o poder de mercado em relação aos seus clientes e, portanto, influenciam diretamente a conduta das empresas. As firmas líderes não conseguem impor preços muito acima do custo médio mínimo da franja, no longo prazo, devido à possibilidade de entrada de novas concorrentes, como apontado no item 2.1. Além disso, como apresentado por Cyrillo (1987), as firmas buscam diferenciar-se e por isso os preços praticados são um pouco acima dos custos médios de longo prazo, mas esse adicional corresponde ao custo de diferenciação.

Como apresentado por Ferreira (2002) e por Rojo (1998), a diferenciação entre os supermercados é geralmente baseada na sua reputação que está vinculada principalmente a um nível de preço de uma cesta de produtos, mas também a qualidade dos serviços e localização da loja. Partindo do pressuposto que esses últimos dois itens são fixos no curto prazo, pois necessitam de investimentos (construção ou compra de novas lojas, treinamento de funcionários, aquisição de equipamentos etc.), ou, no caso dos serviços, ainda podem ser facilmente imitado, quando requerem baixos investimentos, a principal forma de desenvolvimento de uma reputação, para atrair o consumidor no curto prazo, é o preço dos produtos vendidos. Neste caso, é provável que os supermercados atuem seguindo o modelo de Bertrand em uma guerra de preços, chegando a valores próximos aos de competição perfeita. Porém, como as empresas líderes têm custos menores do que a franja, conseguem obter, ainda, uma margem de lucro.

Seguindo a linha de raciocínio de Dobson \& Watson (1997), o aumento de concentração deve levar os supermercados, portanto, a exercerem seu poder de barganha junto aos fornecedores e não para os consumidores, devido às características do setor. 
Neste setor, o marketing é, portanto, um importante instrumento na busca de diferenciação entre os supermercados, pois, como visto, o consumidor percebe as lojas como bons substitutos. Neste cenário, encontram-se grandes redes que investem muito em propaganda e empresas menores que não têm condições de realizar estes gastos. Nas campanhas publicitárias, sejam elas pela TV, rádio, jornal ou tablóides, são enfocados principalmente os preços dos produtos em oferta, mas também aparecem a qualidade dos produtos e serviços. O setor também investe em pesquisas junto aos clientes, ou através de dados de vendas, para compreender melhor os hábitos de consumo. Estas informações são fundamentais para obter o mix ideal de produtos de cada loja, o que é importante para atender as expectativas do consumidor, aumentar o giro dos produtos e, desta forma, eleva as vendas e a rentabilidade dos estabelecimentos.

As mudanças no hábito de consumo, compras mais freqüentes e menores, influenciam no formato das lojas, privilegiando àquelas mais próximas aos consumidores, fato que está sendo observado com o aumento na participação das lojas de vizinhança. A Figura 12 mostra a redução da área média por loja de mais de $12 \%$ entre os anos de 1997 e 2001. Confirmando esta tendência, o número médio de caixas por loja também se reduziu, pois a área média das lojas por caixas manteve-se praticamente constante ao longo do período, um pouco menos de $100 \mathrm{~m}^{2}$ por caixa. 


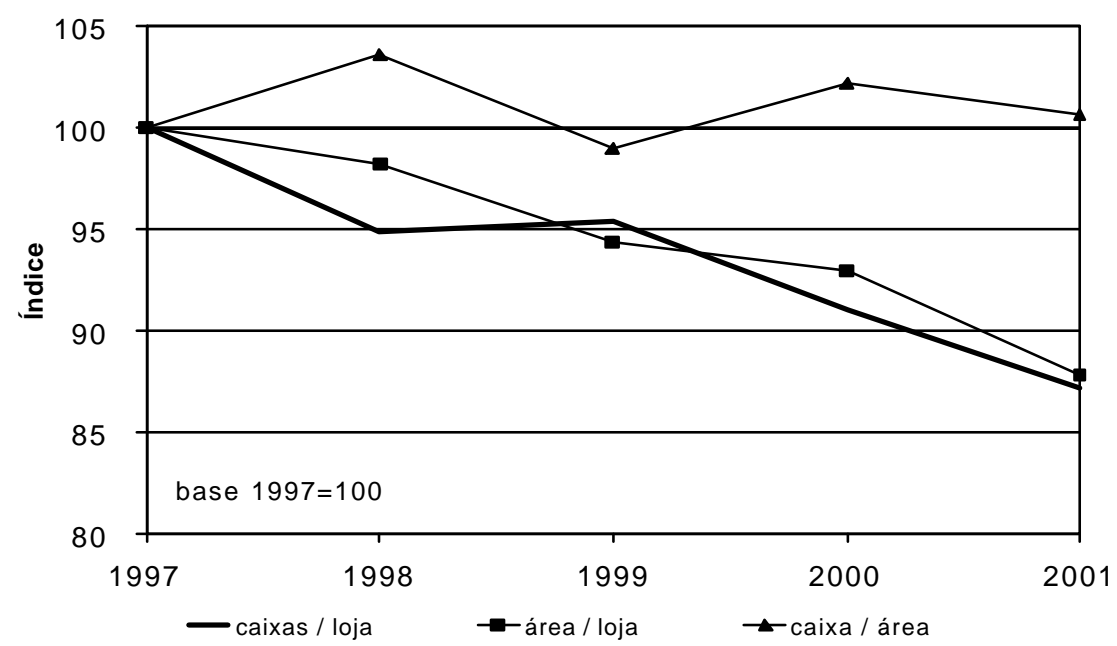

Figura 12 - Variação de índices selecionados entre os anos de 1997 e 2001.

Fonte: ABRAS (2002), cálculo do autor.

A integração vertical é uma estratégia presente no setor. A busca na redução dos custos levou as redes a centralizarem suas compras e, quando possível, o recebimento e a distribuição dos produtos. Desta forma, passaram a atuar no lugar dos atacadistas. Entre as economias encontradas neste sistema, tem-se, além das citadas anteriormente, a redução da carga tributária dos impostos em cascata, pois, caso os produtos fossem comprados por intermediários e repassados aos supermercados, sofreriam a bitributação.

O setor, a partir da segunda metade da década de 90, realizou também investimentos em automação visando melhorar o atendimento ao cliente e a eficiência operacional. Estas condutas são uma resposta às mudanças das características na demanda que ocorreram após a redução das taxas de inflação. E, também, uma forma de buscar a manutenção das margens de lucro, devido à redução dos ganhos financeiros e a dificuldade em aumentar os preços.

\subsubsection{Desempenho}

As Figuras 13 e 14 apresentam a evolução de alguns índices selecionados de 
eficiência para o setor. A primeira mostra o aumento no faturamento bruto do setor em relação ao número de empregados, indicando crescimento da produtividade do trabalho em relação ao capital, podendo estar relacionado ao processo de automação do setor. Outro aspecto que se pode observar pela Figura 13 é a redução do número de funcionários por loja, que pode estar relacionado a dois fatores principais, a diminuição do tamanho médio das lojas e ao crescimento da produtividade da mão-de-obra. Também fica evidente, por essa figura, a diminuição do faturamento bruto por loja indicando a tendência de expansão acima da taxa de crescimento da receita do setor e o aumento das lojas de vizinhança, que por serem menores possuem faturamento inferior.

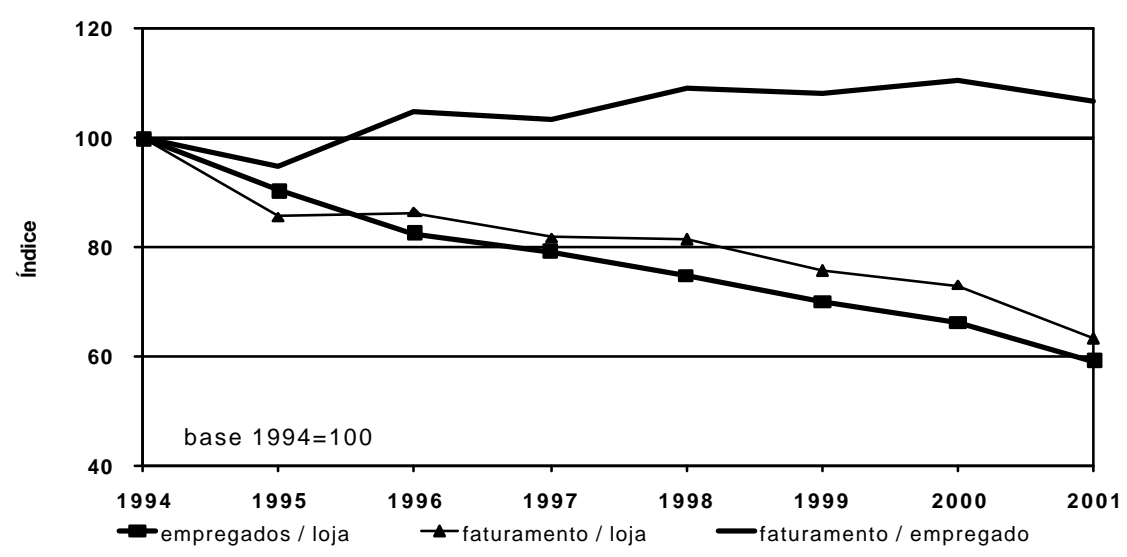

Figura 13 - Índices de eficiência selecionados entre os anos 1994 e 2001 para o setor de auto-serviço.

Fonte: ABRAS (2002), cálculo do autor.

A melhora na eficiência operacional, com o processo de automação, por exemplo, pode ser observado pelo ligeiro crescimento da média do lucro líquido, em relação ao faturamento, como apresentado na Tabela 10. Porém, refletiu-se igualmente no aumento da produtividade da mão-de-obra do setor, como pode ser confirmado pela redução de número médio de funcionários por área (Figura 14), como já citado. O faturamento por área também possui uma tendência de baixa a partir de 1998 reforçando a idéia que o setor expandiu-se mais rapidamente do que o faturamento. 


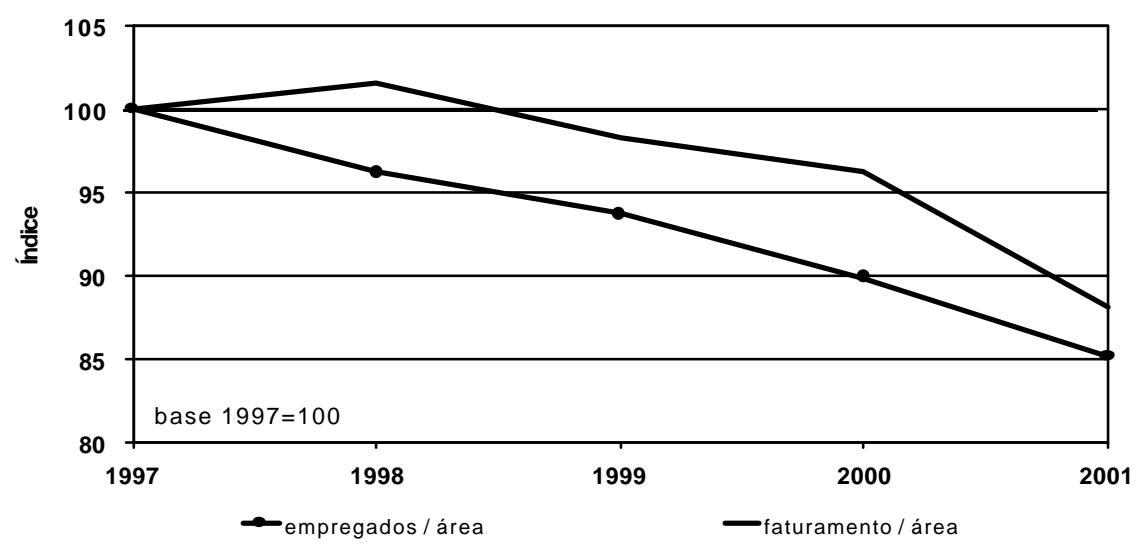

Figura 14 - Índices de eficiências selecionados entre os anos de 1997 e 2001 para o setor de auto-serviço.

Fonte: ABRAS (2002), cálculo do autor.

A melhora na eficiência do setor pode ter sido incentivado, entre outros motivos, pelas características da estrutura de mercado, uma vez que o lucro da empresa está mais relacionado aos seus custos do que ao exercício do poder de mercado. Como observado no item 5.1.2, na Figura 11, as maiores empresas em faturamento têm menor participação no setor em relação ao número total de check-outs, área de vendas, número de funcionários e principalmente na quantidade de lojas, mostrando maior eficiência na utilização dos recursos. Além disso, o setor apresenta economias de escala, favorecendo as empresas dominantes. Isto enfatiza a importância dos pequenos supermercados em buscarem estratégias que os tornem mais eficientes.

\subsubsection{Políticas públicas}

Políticas públicas interferem diretamente no setor. A oferta de produtos comercializados pelos supermercados e seus serviços são influenciados por impostos, taxa de câmbio, política industrial, pela regulamentação, controle de preços, entre outros. A demanda pelos serviços e produtos sofre interferência da renda da população, por exemplo. 
A abertura da economia, a partir do início década de 90, influenciou principalmente na oferta de produto por parte da indústria, possibilitando a importação de itens novos e/ou mais baratos. Isto iniciou um processo de redução de poder de negociação da indústria. Ainda, a estabilização da economia, na segunda metade da década passada, influenciou tanto a oferta de mercadorias por parte dos fornecedores como a demanda pelos produtos dos supermercados pelos consumidores.

No lado da demanda, a estabilidade nos preços possibilitou aos consumidores memorizarem e compararem preços, buscando os estabelecimentos que oferecessem menores preços como melhores serviços, pois os supermercados são vistos como bons substitutos. No lado da oferta, acirrou a disputa entre fornecedores e supermercados, pois o varejo não podia mais repassar aumentos de preço exigidos pelos fornecedores, devido ao comportamento do consumidor. Assim, os supermercados buscaram outras formas para aumentar sua rentabilidade, melhorando a eficiência operacional, buscando economias de escala, entre outros modos, o que está resultando em um aumento da concentração no setor.

O governo, entretanto, não interfere significativamente neste processo de concentração, pois percebe que é pouco provável o uso de poder de mercado pelos supermercados para reduzir o bem-estar do consumidor, devido às características do setor, como se observa em muitos dos pareceres da SEAE/MF.

\subsubsection{Relação esquemática entre estrutura, conduta e desempenho}

Pela Figura 15, são apresentadas esquematicamente as relações entre estrutura, conduta e desempenho no setor supermercadista. 


\section{Condições Básicas}

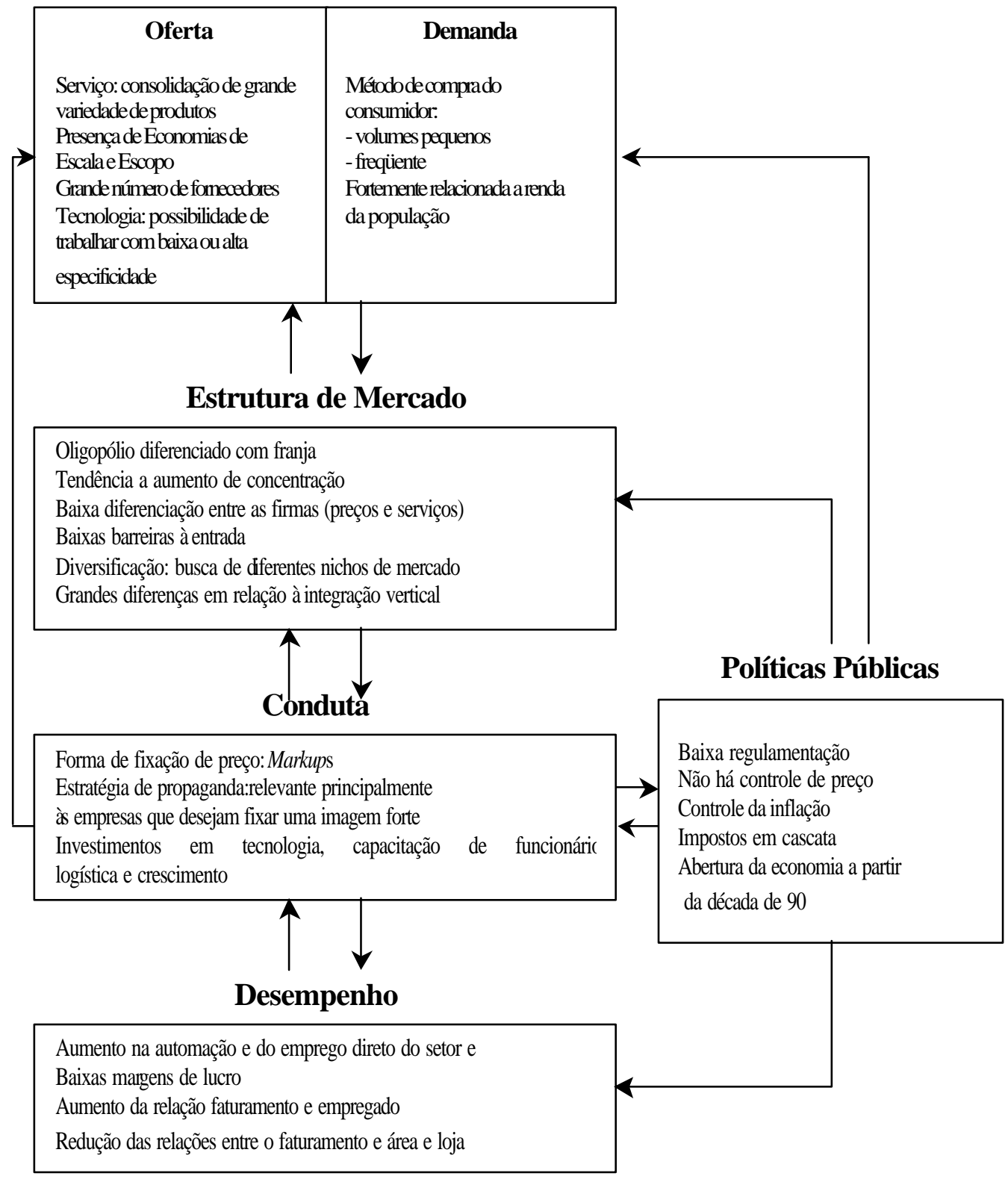

Figura 15 - Resumo da estrutura-conduta -desempenho para o setor supermercadista.

Fonte: Dados da pesquisa. 


\subsubsection{Relação entre as mudanças no setor supermercadista e formação das associações}

Seguindo o raciocínio do modelo da estrutura-conduta-desempenho, pode-se entender a função das associações para os pequenos supermercados. As empresas, segundo Cyrillo (1987), têm como objetivo crescer seja para manterem ou aumentarem sua participação no mercado. Juntamente com as mudanças no comportamento do consumidor (referente às condições básicas), a existência de economias de escala (relacionada à estrutura de mercado) e o controle da inflação (relativo às políticas públicas), motivaram as grandes redes a adaptarem sua conduta, procurando ganhos de eficiência e novos nichos de mercado, entre os quais se encontra a franja. Desta mesma forma a conduta das empresas está influenciando a estrutura do setor, tornando-o, por exemplo, mais concentrado.

A Figura 16 apresenta esquematicamente as principais alterações no setor supermercadista, que se aceleraram principalmente após a segunda metade da década de 90. Observa-se que a estabilização econômica (relativo às políticas publicas) interferiu em três pontos importantes no setor (referente às condições básicas): aumento no consumo de alimentos, modificação no comportamento do consumidor e redução dos ganhos financeiros dos supermercados. Isto refletiu diretamente na conduta das empresas, tanto grandes como pequenas. 


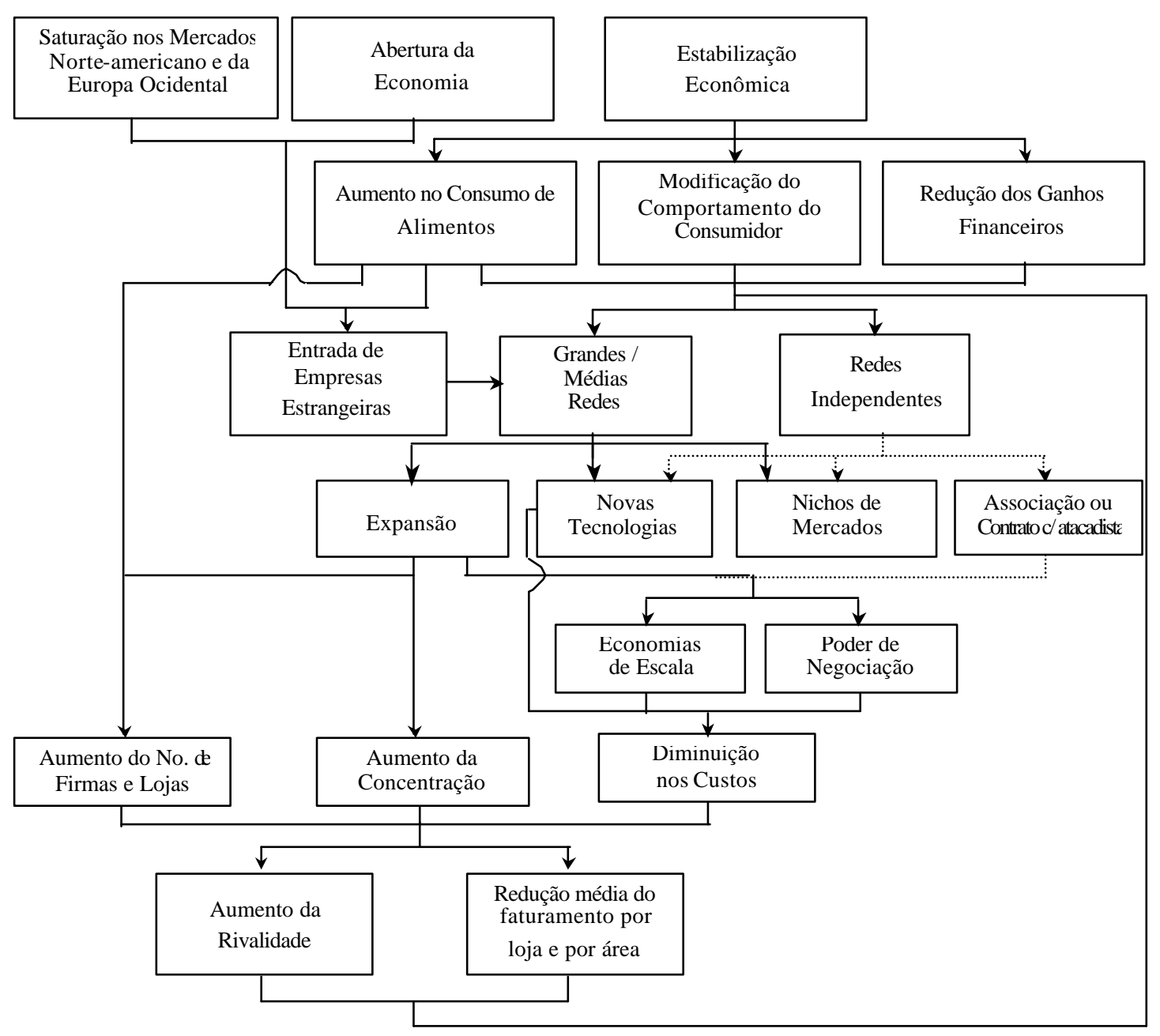

Figura 16 - Esquema das transformações do setor supermercadista na década de 90.

Fonte: Pesquisa do autor, baseada em Wilder \& Sesso Filho (2002)

A saturação dos mercados dos Estados Unidos e da Europa Ocidental incentivaram as empresas a buscarem novos mercados. Com a abertura do mercado brasileiro e o aumento no consumo de alimentos no Brasil, esse campo tornou-se mais interessante para os investimentos. Dessa forma, as empresas transnacionais entraram no mercado brasileiro através de aquisições e/ou fusões com empresas nacionais, estratégia que se manteve para sua expansão, juntamente com a abertura de novas lojas. 
A redução dos ganhos financeiros e a introdução de novas práticas administrativas, trazidas principalmente pelas transnacionais, incentivaram as empresas a buscarem aumento de eficiência. As grandes e médias redes utilizaram-se, para tanto, da (i) introdução de novas tecnologias, como automação comercial - para redução dos custos operacionais e melhora na qualidade dos serviços prestados -, (ii) expansão - para aumentarem as economias de escala, o poder de negociação - e (iii) novos nichos de mercados - para buscar novos consumidores e reduzir a competição direta. Uma consequiência direta da expansão é o aumento de concentração no setor e também aumento do número de lojas, já que as firmas investiram em novos estabelecimentos. A busca de novos nichos de mercados leva ao incremento de rivalidade com a franja, que normalmente atua em áreas que não interessavam às grandes empresas.

As redes independentes, nos quais se encontram os pequenos supermercados, também buscaram estratégias para se adaptarem ao novo ambiente competitivo. A linha tracejada na Figura 16 indica que estas táticas ainda são pouco utilizadas em relação ao número de empresas que existem neste segmento. Pode-se destacar três estratégias que não são excludentes: (i) adoção de novas tecnologias para aumento de eficiência operacional, que dependendo de seu porte ainda são caras, (ii) participação de associações ou criando vínculos com atacadistas (como o sistema IGA ou a rede Smart), buscando economias de escala (que incluem as economias dos custos de transações) e poder de negociação, tentando, assim, aproximar-se de algumas vantagens das grandes e médias redes e (iii) busca de novos nichos de mercado (para reduzir a concorrência direta de outras lojas).

Na segunda metade da década de 90 houve uma expansão no número de lojas de cerca de 46\%. Parte deste aumento ocorreu pela inauguração de novas lojas pelas grandes redes - dentro da estratégia de expansão -, outra e pela abertura de negócios pequenos e médios. O investimento em novos estabelecimentos foi incentivado, em parte, pelo aumento do consumo de alimentos proporcionado pelo crescimento da renda da população que ocorreu pela estabilização econômica. Como esse crescimento deu-se acima do aumento do faturamento do setor, houve uma redução nas relações entre 
faturamento por área e faturamento por loja.

A utilização de novas tecnologias, tanto pelas redes independentes quanto pelas grandes e médias firmas, associada a economia de escala e aumento de poder de negociação, obtidas ou pela expansão, para as grandes firmas, ou pelas associações, para as firmas menores, permitiram que houvesse uma redução nos custos operacionais do setor.

A adoção das estratégias de expansão, novas tecnologias, nichos de mercado e associação, juntamente com o crescimento na concentração da renda bruta do setor pelas grandes empresas e o aumento no número de novas firmas e lojas, acirram a rivalidade no setor. Além disso, a busca pela redução nos custos e o aumento de número de firmas e lojas observados no período proporcionou uma redução no faturamento por área e por loja. Estes fatores, por sua vez, interferem na conduta das empresas, tanto grandes como pequenas, fechando o ciclo.

Porém, será que os supermercados associados estão obtendo vantagens participando dessas organizações? Com intuito de responder a esta questão, foi realizada uma pesquisa com os supermercados associados às redes Economize, de Piracicaba e Econômica, de Limeira, através de um questionário de perguntas fechadas, como descrito no item 4.2 e apresentado no Apêndice 2. Os principais resultados relacionados à segunda parte do questionário são apresentados a seguir.

\subsection{Apresentação das redes estudadas}

O presente item visa apresentar resumidamente as associações, que são o objeto de estudo deste trabalho, e os resultados relevantes obtidos através dos questionários respondidos pelos membros das redes. 


\subsubsection{Rede Econômica ${ }^{41}$}

A rede Econômica, fundada em 1999, conta atualmente com 12 associados, com 16 lojas espalhadas pela cidade de Limeira e uma em Iracemápolis. Limeira, com uma população, segundo o IBGE (2002), de 249.046 em 2000, possuía, no mesmo ano, 61 supermercados, conforme o censo da Associação Paulista de Supermercados - APAS. Iracemápolis, para as mesmas fontes, contava com 15.555 habitantes e 6 supermercados.

Os $\operatorname{associados}^{42}$ são compostos por lojas que possuem área de no máximo 600 metros quadrados, mais de $90 \%$ deles têm lojas com até quatro caixas e $83 \%$ vendem até 7.000 itens, caracterizando, portanto, supermercados compactos. São, também, empresas familiares.

Os estabelecimentos ficam abertos entre 70 e 80 horas semanais e a maioria funciona seis dias por semana. Cerca de $92 \%$ das lojas faturam entre 100 e 300 mil reais mensais, o restante fica entre 300 e 500 mil reais mensais. A grande maioria, 83\%, possui apenas uma loja, sendo que um associado possui três lojas e outro possui duas.

A idéia da associação surgiu no final de 1998 e seu idealizador é o atual presidente e dono de uma loja em Limeira. Na escolha dos associados, buscou-se selecionar as melhores lojas em diferentes bairros para que não houvesse rivalidade direta entre elas. $\mathrm{O}$ intuito original da associação era a compra em conjunto, fato que ocorreu por alguns meses. Porém, teve de ser descartada, devido à Contribuição para Financiamento da Seguridade Social (COFINS) de 3\%, ao PIS/PASEP de 0,65\% (ambos incidindo sobre a receita auferida pela pessoa jurídica) e à Contribuição Provisória sobre Movimentação ou Transmissão de Valores e de Crédito e Direito de Natureza Financeira

\footnotetext{
41 Entrevistas realizadas nos dias 24/07/2002 e 18/08/2002, com o Sr. Ismael Calsa, presidente da as sociação.

${ }^{42}$ Dados obtidos por questionários respondidos pelos associados, as tabelas referentes à estas informações encontram-se no Apêndice 3.
} 
(CPMF) de $0,38 \%$, pois os descontos obtidos pela compra conjunta eram menores do que os custos dos tributos. Além disso, os preços dos atacadistas são, segundo o presidente da associação, próximos aos da indústria quando ocorre a venda direta. Isto acontece porque o volume comprado pelos atacadistas é muito maior do que a quantidade que a rede adquire e, ainda, as indústrias os procuram para completarem a cota de venda mensal, dando-lhes descontos maiores.

A associação buscou, portanto, alternativas à compra conjunta. Atualmente, possui um cartão de crédito com seu nome (gerida pela Fininvest), faz propaganda conjunta em jornais, rádios e tablóides, tem uma bandeira comum, realiza negociações conjuntamente e organiza palestras para seus associados e funcionários dos supermercados, visando motivá-los a melhorarem a qualidade de atendimento aos clientes, entre outras atividades.

As negociações conjuntas possibilitaram a realização de acordos de fidelização com os fornecedores. Para tanto, são escolhidos fornecedores em comum entre os associados. Em uma reunião, é explicado o funcionamento do sistema, que consiste em o fornecedor escolher uma taxa sobre o valor total mensal faturado para os associados, chamada de taxa de fidelização, que é repassada para a associação, além de, comprometer-se a cobrar o preço de mercado em seus produtos (para não acrescentar aos preços o valor pago para a associação). Em contrapartida, os associados obrigam-se a comprar os produtos do fornecedor durante o período do contrato. Os fornecedores que propuserem melhores vantagens são selecionados. Estes contratos têm normalmente prazo de um ano, e, geralmente, são acordados com dois ou três fornecedores para o mesmo tipo de produto. A fiscalização do cumprimento do contrato é realizada pelos próprios fornecedores.

As taxas de fidelização são diferentes conforme o tipo de produto e variam de $0,5 \%$ a $15 \%$. Os itens da cesta básica possuem as menores taxas como, óleo de soja e leite longa vida que têm taxas de $0,5 \%$ e o arroz com 1\%; os utilitários como encartelados, que têm uma margem de venda maior, chegam a uma taxa de $15 \%$. 
A taxa de fidelização é paga à associação mensalmente pelos fornecedores e distribuída aos associados proporcionalmente ao volume de compras de cada item, em forma de crédito. Os custos fixos, juntamente com os de propaganda em jornal e rádio, são rateados por loja, os gastos com tablóides ou encartes são divididos pela quantidade de exemplares que cada loja recebeu. A diferença entre o crédito que cada loja possui e as despesas é paga caso for positivo ou cobrada, caso negativo, pela associação.

Conforme o presidente da associação, cerca de $80 \%$ dos membros não têm mais despesas com a associação e marketing. Segundo ele, com o aumento do número de empresas fidelizadas, atualmente são 93, essa participação deve chegar a 100\%.

As principais vantagens para os fornecedores, apontados pelo presidente da associação, são a garantia de acesso às lojas, pois têm contrato de venda com uma rede de 17 estabelecimentos em uma única região e a diminuição dos custos de negociação, porque não há necessidade de visitar e negociar os preços em cada loja para retirar os pedidos, bastando uma única visita a associação. Além disso, apenas os produtos das empresas fidelizadas fazem parte dos tablóides ou encartes distribuídos pela rede, quando estão em promoção.

Este sistema possibilita aos membros da associação venderem os produtos ofertados em encartes mais baratos, pois além de não terem custos de publicidade, estas mercadorias conseguem descontos junto aos fornecedores devido ao aumento de volume adquirido, permitindo redução do sacrifício das lojas em relação às margens nessas promoções. Isto é, no programa de fidelização, os supermercados comprometem-se a comprar de determinados fornecedores que, em contrapartida, pagam uma taxa à associação e cobram o preço de mercado, porém, dão descontos aos produtos em oferta, pelo aumento de volume. A associação consegue ainda, às vezes, preço de carga fechada, a custo menor, mesmo que o fornecedor tenha que faturar e entregar em cada loja, o que é possível pois todos se encontram em uma mesma cidade.

No início da associação, os contratos eram negociados pelo presidente da 
associação, o que tornava o trabalho dele exaustivo pois tinha que administrar também seu estabelecimento. Por este motivo, foi adotado um rodízio: os associados foram divididos em grupos de três ou quatro pessoas que ficam responsáveis pelo atendimento aos vendedores, negociação e realização dos encartes por dois meses. Desta forma, todos têm a possibilidade de atuar na administração da associação, além de reduzir o número de funcionários. Juntamente com a atuação de seus membros, a associação conta com quatro funcionários que entram em contato com fornecedores, pesquisam preços e realizam serviços gerais.

Os associados trabalham com duas bandeiras, a da Rede Econômica e a sua própria. A utilização do logotipo da associação dá, na opinião do seu presidente, uma imagem de uma rede grande de supermercados na cidade. A associação possui, ainda, um projeto de padronização das lojas, tanto de fachada quanto de interior; porém, devido ao alto custo de implantação, as alterações ocorrem conforme os associados realizam reformas em seus estabelecimentos. As cores escolhidas para a associação são o azul e o laranja, com as quais as fachadas são pintadas.

Os membros da associação reúnem-se semanalmente na sede da associação, um galpão alugado em Limeira, para fazer os pedidos e tomar decisões sobre as ações da associação. O processo de decisão ocorre em reunião e por maioria simples. Segundo o presidente da associação, este sistema pode gerar conflitos com a minoria que se sente prejudicada, porém, nas reuniões, busca-se resolver essas diferenças.

A associação também possui cinco produtos com marca própria; arroz, feijão, achocolatado, alho e café. Segundo o presidente da associação, estes produtos da cesta básica são interessantes, pois impossibilitam a comparação de preços entre as lojas. Como todos supermercados buscam o menor preço entre os fornecedores, normalmente a mesma marca está em promoção em várias lojas da cidade, pois naquele período o fornecedor estava fazendo promoção. Caso o concorrente venda um produto que está no encarte da rede Econômica mais barato, o cliente tem como confrontar a diferença de preço, o que é ruim para a imagem do supermercado. A utilização da marca própria 
reduz essa possibilidade de comparação.

\subsubsection{Rede Economize ${ }^{43}$}

A rede Economize, com sede em Piracicaba, iniciou suas atividades em 1998. A rede possui oito associados com dez lojas, atuando nas cidades de Piracicaba (cinco lojas), Iracemápolis (uma loja), Rio das Pedras (uma loja), Tietê (uma loja) e Rio Claro (duas lojas). A maioria (75\%) dos estabelecimentos tem até quatro caixas, com faturamento até 300 mil reais. Algumas informações sobre as cidades em que atuam são apresentadas nas Tabela 19.

Tabela 19. Dados selecionados sobre as cidades onde atua a Rede Economize.

\begin{tabular}{lcccc}
\hline \multirow{2}{*}{ Cidade } & \multirow{2}{*}{ Habitantes $^{*}$} & \multicolumn{2}{c}{ Número de Super/hipermercados $^{*}$ Participação da Rede } \\
\cline { 3 - 4 } & & Total & Rede Economize & \\
\hline Iracemápolis & 15.555 & 6 & 1 & $16,7 \%$ \\
Piracicaba & 329.158 & 80 & 5 & $6,3 \%$ \\
Rio Claro & 168.218 & 34 & 2 & $5,9 \%$ \\
Rio das Pedras & 23.494 & 8 & 1 & $12,5 \%$ \\
Tietê & 31.710 & 5 & 1 & $20,0 \%$ \\
Total & 568.135 & 133 & 10 & $7,5 \%$ \\
Fonte: IBGE (2002) e APAS (2000) & & & \\
$*$ em 2000 & & & & \\
$* *$ em 2002 & & &
\end{tabular}

A associação chegou a contar com 18 lojas e era mais heterogênea com relação aos seus membros, possuindo um membro com quatro lojas e que chegava a participar com 50\% das compras da rede. Esta disparidade e as diferenças na gestão do negócio geraram atritos internos, pois os maiores sentiam-se prejudicados por contribuírem mais para o volume de compra da associação e, mesmo assim, terem direitos e deveres iguais. Neste período, ainda, o rateio dos custos com a associação era

\footnotetext{
43 Entrevistas realizadas nos dias 23/07/2002 e 27/11/2002 com Sr. Pedro Luiz Defávari, presidente da associação e no dia 17/07/2002, com Sr Eder de Campos Camargo um dos diretores da associação.
} 
baseado pelo valor dos produtos adquiridos pelo associado através da associação, ou seja, quem comprava mais pagava mais. Esses fatores resultaram na saída de alguns associados ao longo do tempo.

A associação realizava compras em conjunto até o final de 2001. Neste período, chegou a ter seis funcionários e alugar um galpão em Piracicaba, onde recebiam as mercadorias compradas, que posteriormente eram faturadas e distribuídas às lojas. Porém, o PIS e o COFINS não estavam sendo recolhidos, o que os obrigou a reorganizar a associação quando tiveram que negociar a dívida com Receita Federal.

Com a desestruturação da rede, devido ao problema fiscal, muitos fornecedores deixaram de atendê-la, pois os pedidos tinham que ser faturados individualmente e, geralmente, não alcançavam as quantidades mínimas exigidas, e as vantagens da compra conjunta não compensavam os custos tributários. Com isso, a associação ficou com dificuldades financeiras devido à perda da verba para propaganda patrocinada pelos fornecedores.

Atualmente, a rede realiza negociação conjunta, contando com cerca de 18 fornecedores fidelizados que fornecem em torno de 200 itens. Os gnhos obtidos com a fidelização, no começo, iam para a associação visando o abatimento da dívida. Porém, pela dificuldade em ratear esses ganhos, entre os associados conforme o volume de compra de cada associado (como ocorre na Rede Econômica), o valor ia diretamente para o abatimento das despesas. Desta forma, como alguns associados não compram determinados produtos dos fornecedores fidelizados (ou para aproveitarem oportunidades de negócio ou por terem dificuldade com a aceitação dos produtos destes fornecedores), e por existirem diferenças entre os volumes de compras entre os associados, prejudicou as lojas que adquiriam maiores somas, pois contribuíam mais com os ganhos financeiros com a fidelização, e não tinham vantagens com as prestações da associação. Presentemente, os membros recebem diretamente dos fornecedores os valores obtidos pela taxa de fidelização e pagam à associação uma taxa referente aos rateios dos seus custos. 
A rede também possui um cartão em seu nome gerido pela Fininvest, mesma empresa da Rede Econômica. Outra atividade conjunta da associação é a realização quinzenal dos encartes com as ofertas. Os custos desses encartes são pagos inteiramente pelos associados e a taxa cobrada dos fornecedores que participam é utilizada diretamente para o abate da dívida com o fisco.

O processo de decisão dá-se por votação e por maioria simples e ocorrem em reuniões mensais ou extraordinárias, quando se tem algo específico para resolver. $\mathrm{Na}$ entrevista também foi apontada a dificuldade em lidar com a minoria e a necessidade de negociar para amenizar as resoluções controversas. Essas dificuldades são, segundo o presidente da associação, causadas pelas diferenças na forma de administrar o negócio.

Os principais problemas da associação, apontados pelo seu presidente, são a falta de espírito associativista de seus membros, que levam a ações individualistas que prejudicam a associação (como não comprar dos fornecedores fidelizados); a necessidade de uma estrutura administrativa melhor, pois atualmente seus membros devem administrar, além dos seus estabelecimentos, também a associação, aumentando muito a carga de trabalho; e exploração dos membros maiores pelos menores, pois estes últimos beneficiam-se mais com as ações da associação (encartes, cartão e negociação conjunta).

\subsubsection{Resultados obtidos com as associações}

Foram entrevistados 20 supermercados, 12 participantes da rede Econômica e 8 pertencentes à rede Economize, correspondente ao número de associados. As principais respostas são apresentadas em forma de figuras para facilitar a visualização, as tabelas com todo os valores obtidos com os questionários encontram-se no Apêndice 3.

Inicialmente, é interessante observar o ambiente competitivo em que se encontram os associados. Dos supermercados pesquisados, 55\% responderam que, nos últimos cinco anos, pelo menos um hiper/supermercado instalou-se próximo a sua loja, destes, 54,5\% afirmaram que não houve queda no faturamento e 45,5\% que a redução 
foi de até $20 \%$ (Questão 47). Três supermercados destacaram que as quedas nas vendas ocorreram apenas no período subsequiente à inauguração do novo concorrente, mas depois as vendas voltaram ao normal.

Entre os dois principais concorrentes percebidos pelos supermercados, a maioria (62,5\%) encontra-se a uma distância de até 2 quilômetros (Questões 35 e 37). Isto indica que os supermercados entendem como principais concorrentes àqueles que se encontram mais próximos a sua loja. Questionados sobre quais os serviços que as lojas apontadas como principais concorrentes são melhores do que seus estabelecimentos, os itens horário de funcionamento, variedade de produtos e estacionamento foram os mais citados pelos associados (Questões 38 a 46).

Os serviços prestados pelos supermercados são importantes fatores de diferenciação em relação aos concorrentes. Portanto, foi apresentada uma série de serviços aos supermercados. Eles foram questionados se os possuem, e caso não o forneçam, se pretendem ou não fazê-lo. Todos os supermercados associados oferecem hotifrutis e serviço de açougue; $75 \%$ deles prestam serviços de frios e laticínios; apenas metade, de padaria, apesar de $35 \%$ ter a intenção de fornecer tal serviço. Trinta e cinco por cento das lojas possuem promotores de venda e outros $25 \%$ planejam ter. Trinta por cento têm rotisserie na loja, e apenas outros $25 \%$ planejam realizar esse serviço (Questões 11 a 16).

Todas as lojas da Rede Econômica possuem a marca própria e programa de fidelidade; na rede Economize, apenas 50\% oferecem produtos com a marca da rede e 87,5\% disponibilizam o programa de fidelidade da associação. Oitenta e cinco por cento das lojas possuem caixas automatizadas, e 75\% utilizam Sistema de Integração Frente e Retaguarda (Questões 17 a 20).

Dos associados que responderam, todos possuem balanças eletrônicas. O serviço de entrega a domicilio é realizado por $85 \%$ dos associados; a mesma participação ocorre para o serviço de empacotadores e para presença de vagas exclusivas da loja para carros. Segundo os associados, cerca de $45 \%$ realizam gerenciamento de categorias (Questões 
21 a 25$)$.

Entre $40 \%$ e $50 \%$ dos supermercados não realizam treinamentos nas diversas atividades apontadas para um funcionário recém contratado. Um dos entrevistados afirmou que normalmente contrata pessoas com prática no serviço, dispensando a necessidade de treinamento (Questões 26 a 33).

A Figura 17 apresenta os principais itens apontados como razões para participar da associação. Os custos de propaganda, aumento da rivalidade no setor, dificuldade em se adquirir mercadorias e os altos custos de compra somam 55\% do total das citações. $\mathrm{Na}$ rede Economize, além desses fatores, o distanciamento da indústria também foi muito mencionado, e na rede Econômica, o incremento da profissionalização da concorrência. Esses fatores indicam, portanto, as principais preocupações dos associados.

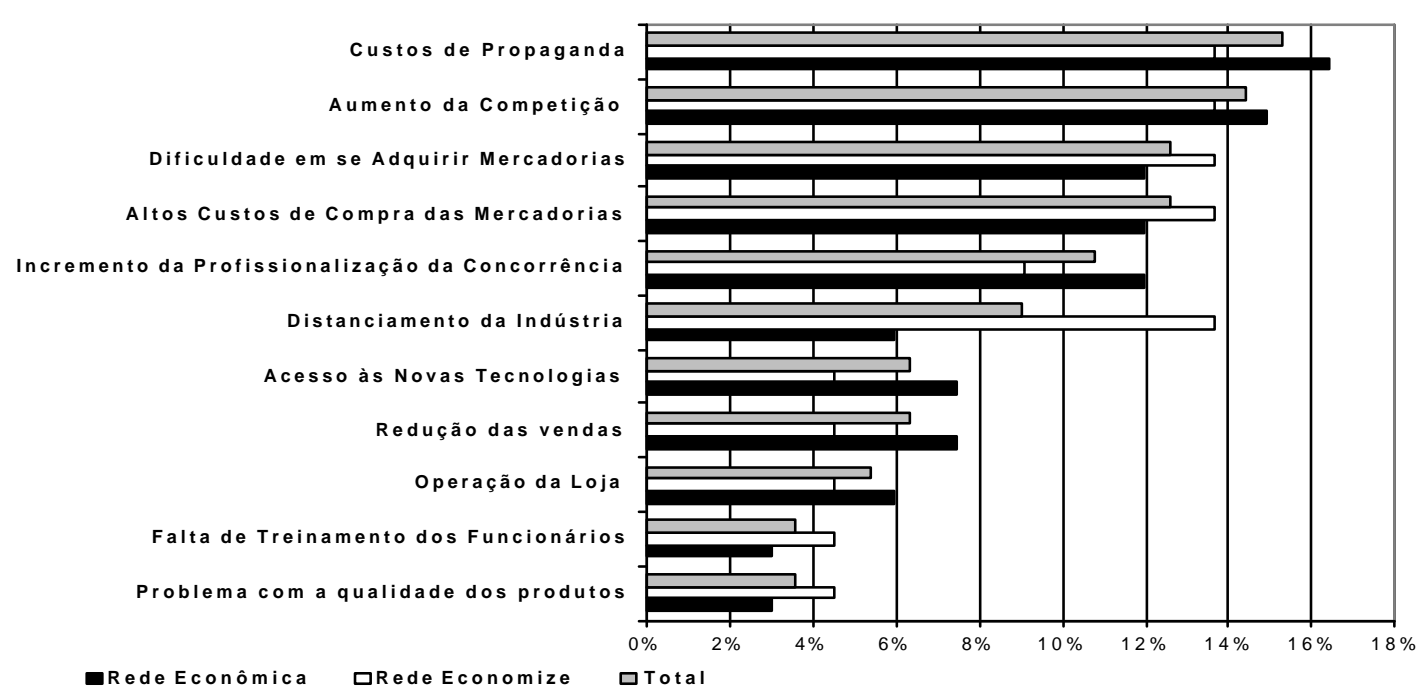

Figura 17 - Principais razões citadas que levaram os supermercados a associar-se àrede.

Fonte: Dados da pesquisa.

A rede Econômica, segundo a pesquisa, é responsável por negociar até $60 \%$ dos produtos comercializados pelas lojas (Figura 18). Na rede Economize este valor é menor, até $40 \%$, e a maioria dos associados, $62,5 \%$, adquire no máximo $20 \%$ de seus 
produtos pela associação. Isso ocorre, pois o número de empresas fidelizadas (18 empresas) é menor do que a Rede Econômica (93 empresas). Segundo o presidente da rede Econômica, a associação não pretende atender todos os itens vendidos pelas lojas, pois existem características regionais de consumo. Em alguns bairros, certas marcas são mais demandadas do que outras, não havendo, portanto, interesse na negociação conjunta desses produtos.

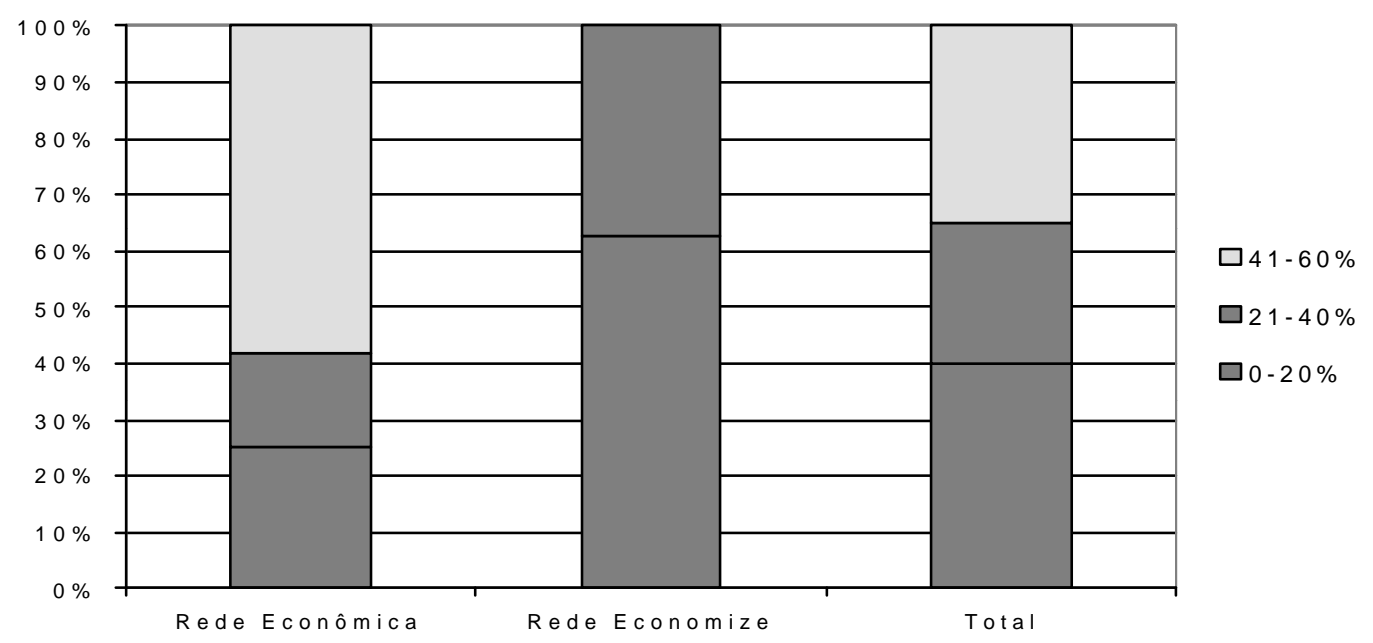

Figura 18 - Participação dos itens fornecidos a partir de negociações conjuntas da associação no total dos itens vendidos pela loja.

Fonte: Dados da pesquisa.

A Figura 19 apresenta faixas percentuais de redução nos custos de aquisição das mercadorias negociadas pela associação. Observa-se que, na rede Econômica, a redução nesses custos ficou entre 2,1 a 4\% para 58\% dos associados, e, na rede Economize, foi apontado por $25 \%$ de seus membros. Já a maioria (37\%), nesta última, citou redução maior do que 6\%. Estas reduções nos custos dos produtos adquiridos ocorrem principalmente com aqueles que participam das promoções apresentadas nos encartes. Neste caso, os frnecedores reduzem os preços devido ao aumento do volume adquirido. Normalmente, como os associados não têm condições de realizar individualmente a produção desses encartes com promoções, não obtêm esses descontos dos fornecedores. 


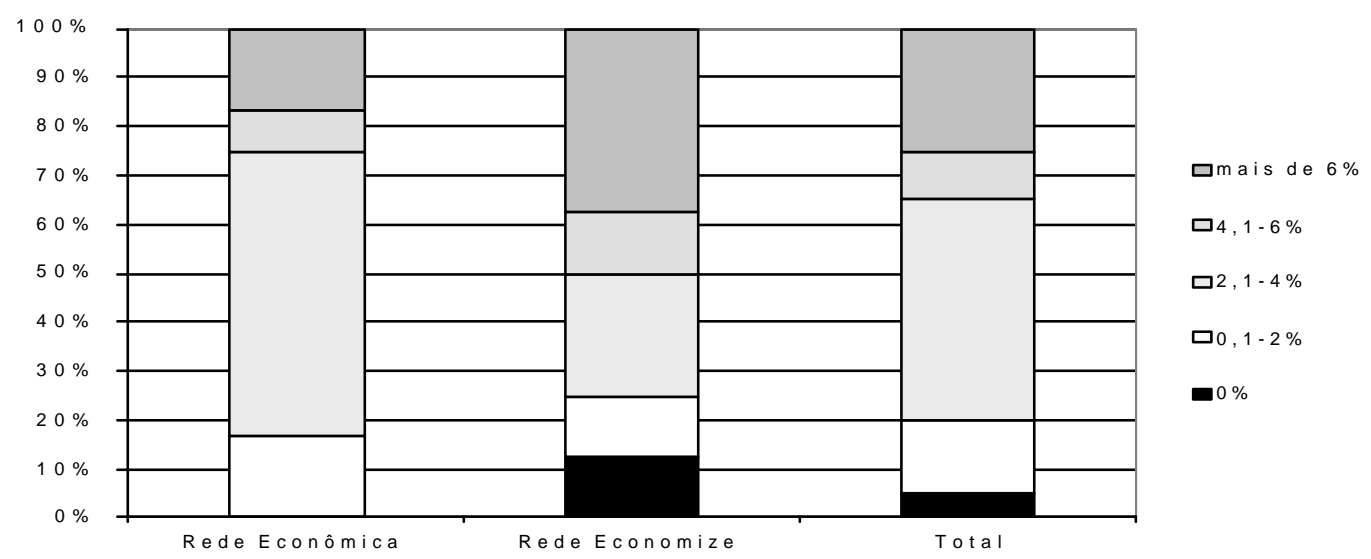

Figura 19 - Redução nos custos de aquisição dos produtos comprados pela associação, distribuição percentual por faixa de decréscimo.

Fonte: Dados da pesquisa.

Apenas um supermercado de cada rede reduziu o número de funcionários (Figura 20). Nesses supermercados, a compra dos itens comercializados é realizada geralmente pelo próprio dono da loja. A negociação em conjunto, portanto, não reduz diretamente a necessidade de funcionários das lojas.

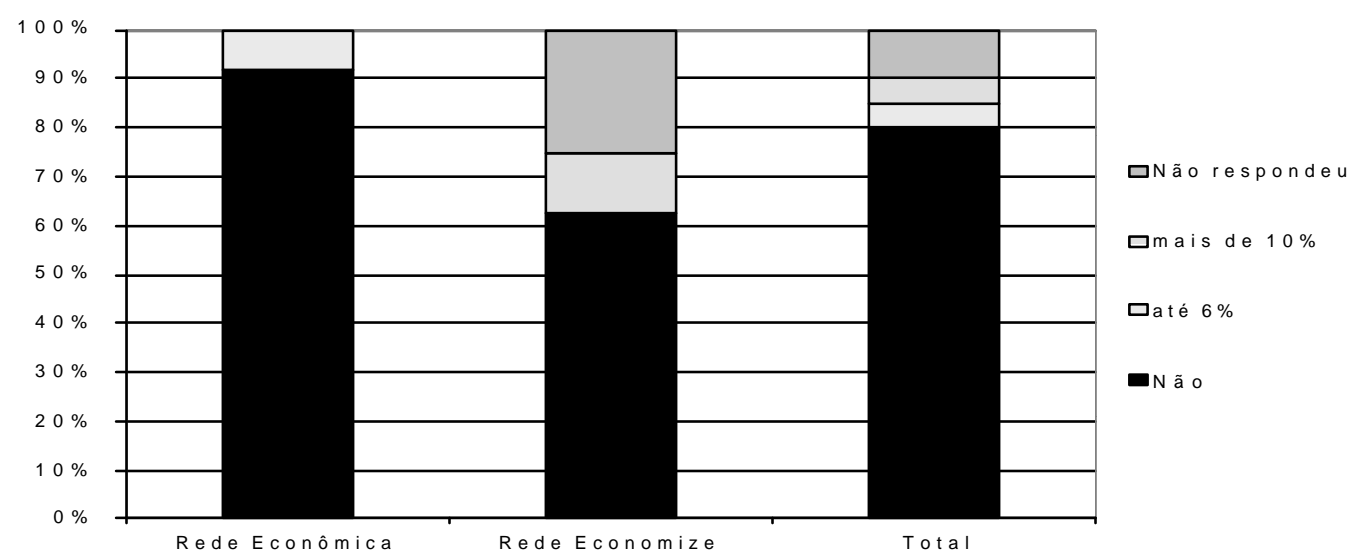

Figura 20 - Redução no número de funcionários após a entrada na associação, distribuição percentual por faixa de decréscimo.

Fonte: Dados da pesquisa. 
Esperava-se que as negociações em conjunto permitissem a redução nos estoques, pois possibilitaria compras mais freqüentes pela redução na exigência do volume mínimo do pedido. Porém, observa-se que isso não ocorreu para a maioria das lojas, em ambas as redes. Segundo o presidente da rede Econômica, isto pode ser explicado pela cultura adquirida nos tempos de inflação alta, nos quais era vantajoso ter altos estoques. Muitos dos supermercados ainda possuem áreas de depósito e preferem realizar compras maiores e menos freqüentes (Figura 21).

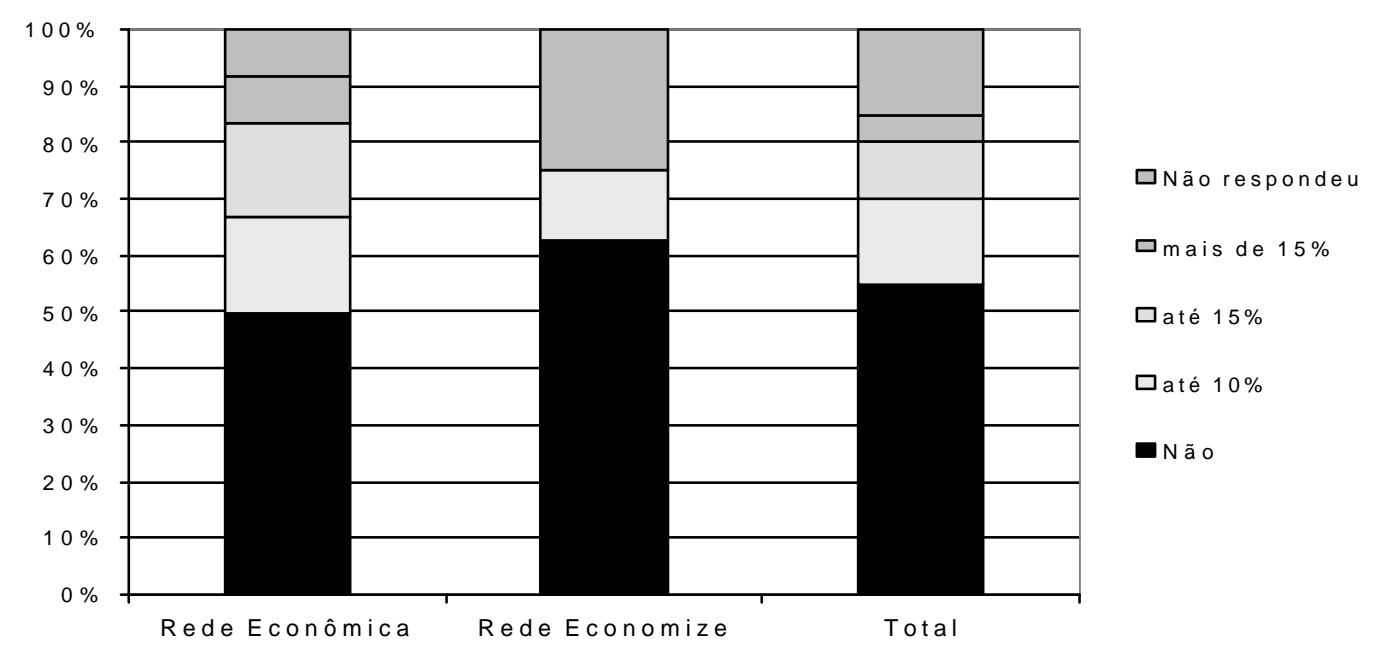

Figura 21 - Redução nos estoques, distribuição percentual por faixa de decréscimo.

Fonte: Dados da pesquisa.

Percebe-se pela Figura 22 que a grande maioria dos associados apontaram redução nas faltas de produtos nas prateleiras. Segundo o presidente da rede Econômica, isso ocorreu pelo melhor controle nos estoques, que o sistema de pedidos da associação proporcionou. Esta rede distribui semanalmente uma lista para serem anotados os pedidos, obrigando ao supermercadista verificar o estoque. 


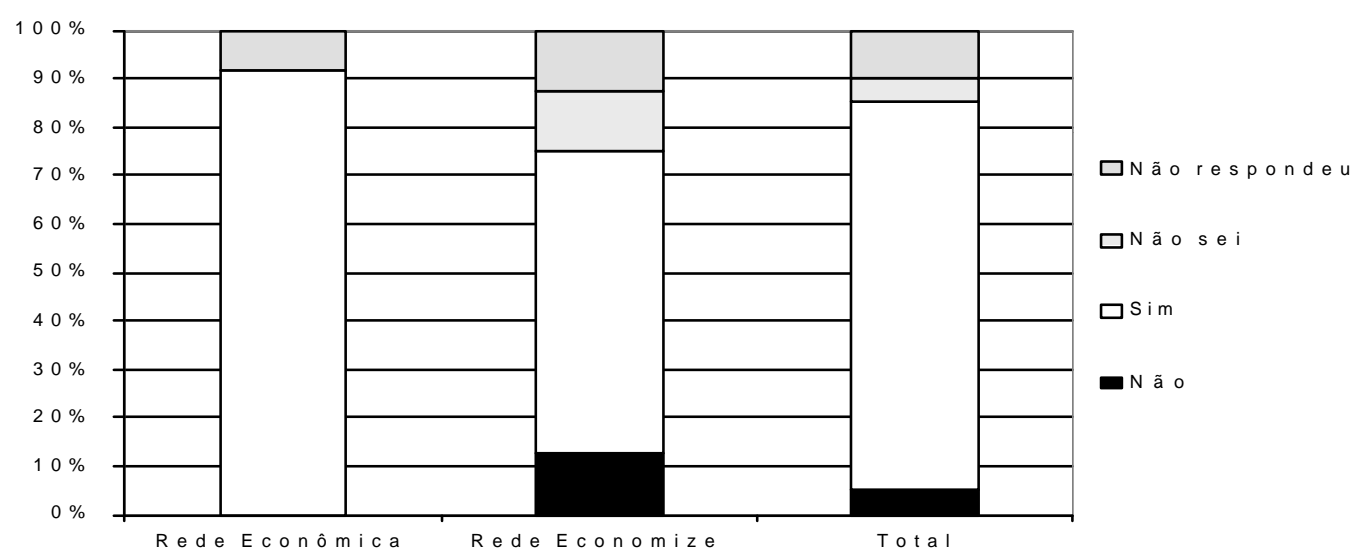

Figura 22 - Redução nas faltas de produtos nas prateleiras, distribuição percentual por faixa de decréscimo.

Fonte: Dados da pesquisa.

Cerca de $90 \%$ dos associados da rede Econômica e 50\% dos membros da rede Economize reduziram os preços dos produtos vendidos. Esta redução concentrou-se, nas duas redes, na faixa até $6 \%$. Isto indica que os supermercados destas associações estão, na sua maioria, conseguindo tornarem-se mais competitivos, respondendo ao aumento de rivalidade, uma das razões apontadas para a entrada nas associações (Figura 23).

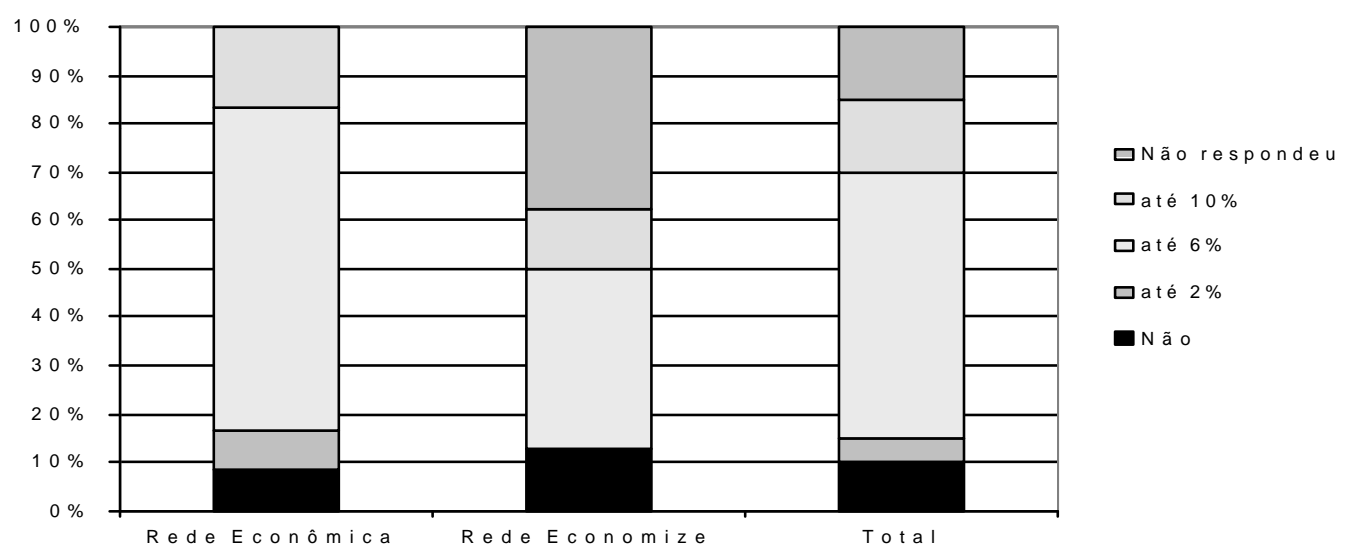

Figura 23 - Redução percentual nos preços, distribuição percentual por faixa de decréscimo.

Fonte: Dados da pesquisa. 
A Figura 24 mostra que a maioria dos supermercados pesquisados indica melhora na qualidade dos produtos, que está relacionada principalmente aos produtos perecíveis. Neste caso, a importância da rede para os fornecedores faz, segundo presidente da Rede Econômica, com que busquem entregar produtos de melhor qualidade.

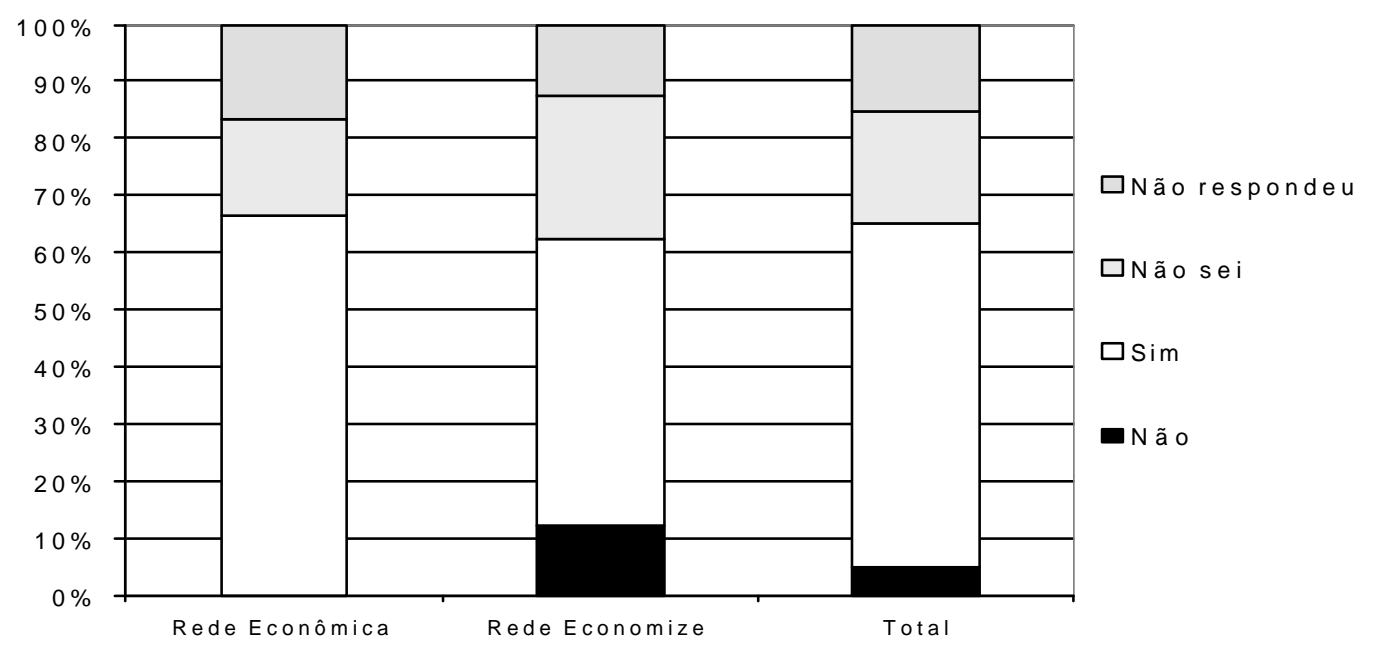

Figura 24 - Melhora na qualidade dos produtos.

Fonte: Dados da pesquisa.

A melhora no atendimento é apontada por todos os associados que responderam à questão (Figura 25). Pelo menos na rede Econômica, este fato pode ser creditado a palestras realizadas pela associação aos seus membros. A rede Economize não realizou estes eventos, mas apontou a necessidade de desenvolver a imagem institucional da associação através da comunicação com os clientes, da qualidade do trabalho, dos produtos e do atendimento, buscando a diferenciação que não seja baseada somente nos preços. Esta visão pode ter incentivado a melhora neste ponto. 


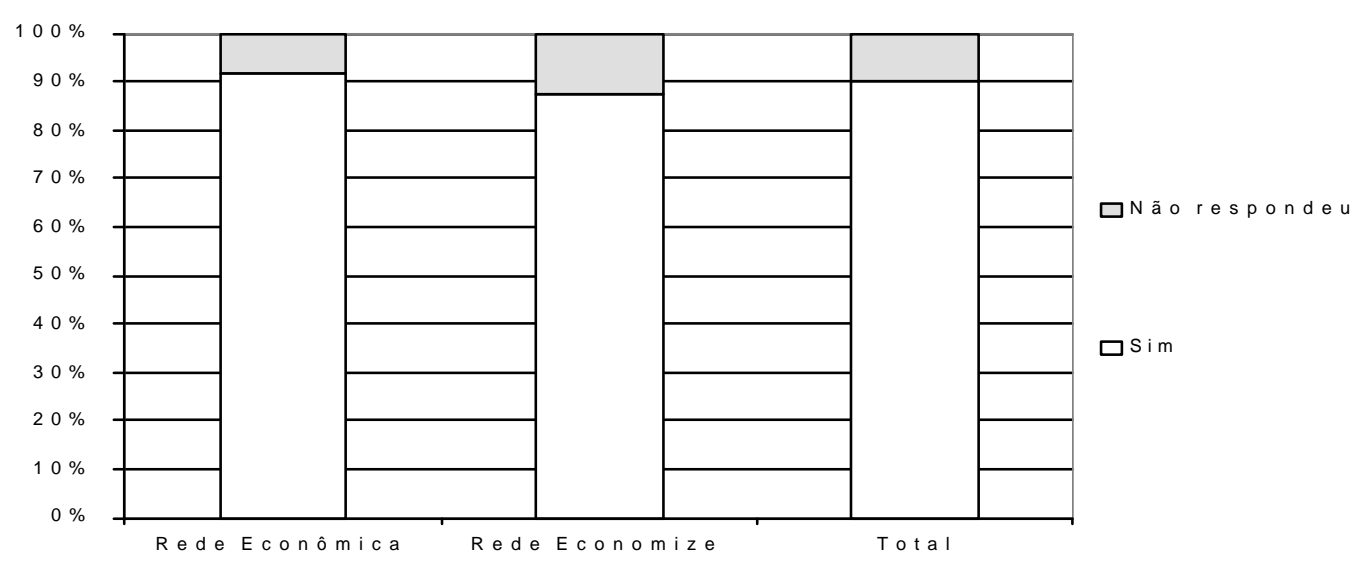

Figura 25 - Melhora no atendimento ao cliente.

Fonte: Dados da pesquisa.

A Figura 26 apresenta o aumento médio percentual no faturamento dos supermercados após a entrada na associação. Em 65\% das lojas esse aumento foi de mais de $10 \%$. Isto pode ser creditado, segundo os entrevistados, ao tablóide e ao cartão da rede. O primeiro por divulgar as lojas e as ofertas e possibilitar melhores preços com os fornecedores, como já mencionado, e o segundo por melhorar os prazos de pagamento das compras.

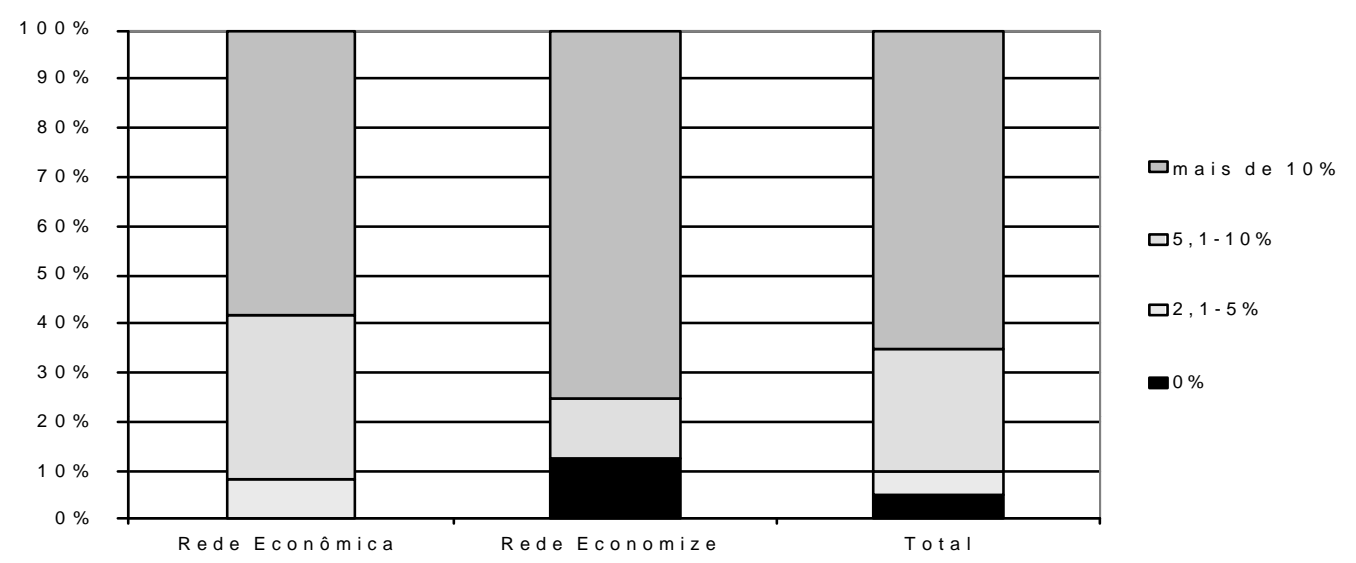

Figura 26 - Aumento médio percentual no faturamento da loja com a entrada na associação.

Fonte: Dados da pesquisa. 


\subsection{Economia dos Custos de Transação e as redes}

Como apresentado no item 2.2.1, a ECT baseia-se em dois pressupostos comportamentais, racionalidade limitada e oportunismo. $\mathrm{O}$ primeiro, implica na capacidade restrita dos agentes em receber, estocar, recuperar e processar informações. Desta forma, a difusão e o processamento da informação não é perfeita e têm custos.

Por este motivo, os supermercados devem realizar um esforço para reduzir a assimetria de informações pesquisando, entre os fornecedores, aqueles que melhor o atendem em termos de preços, prazos de pagamento e entrega, quantidades mínimas de compra, qualidade dos produtos etc., o que gera despesas. Ao constituir uma associação, parte deste trabalho pode ser realizado uma única vez, beneficiando várias lojas com o mesmo custo. Com isso, os gastos para obtenção de informações são diminuídos.

Com informações de mercado centralizadas, a associação pode negociar melhor a compra em nome de todos os membros. Além disso, ambas a partes economizam, o fornecedor, tendo que negociar uma única vez, como foi apresentado por Essing (2000), poupando tempo, gastos com transporte, etc. E o supermercado, por ter sua compra pesquisada e negociada pela organização em melhores conduções.

O aumento do volume comercializado pela associação junto a um fornecedor permite, ainda, melhor posição de barganha e possibilita a realização de contratos por períodos mais longos. No caso das redes, estes acordos são de um ano, e são denominados programas de fidelização. Estes resultam também no incremento da frequiência de compras com um mesmo fornecedor, o que, por sua vez, ajuda a diluir custos de negociações.

Esses contratos de prazos mais longos reduzem, igualmente, as incertezas dos fornecedores por dois fatores principais. Eles têm preferência na venda de seus produtos para as lojas associadas, que, no caso de Limeira são 16 lojas (26\% do total de lojas da cidade) e da rede Economize, dez lojas. E há a redução de assimetria de informação pela criação de reputação, dada ao aumento da frequiência das transações. 
Entretanto, as redes precisam prevenir-se em relação à redução da incerteza dos fornecedores, que podem aproveitar-se do compromisso dos supermercados e praticar preços acima do mercado, agindo de forma oportunista. Para tanto, os supermercados acrescentam ao contrato a obrigatoriedade dos preços dos fornecedores serem iguais aos do mercado, caso contrário à associação poderá comprar de outro fornecedor, pois não interessa aos supermercados obterem a taxa de fidelização apagando preços acima do mercado. Com isso, buscam reduzir as ações oportunistas dos fornecedores.

As redes procuram, portanto, obter parte das economias alcançadas pelos fornecedores com a redução dos custos de transação pela taxa de fidelização.

O Ambiente Institucional, como visto na teoria, também interfere nos custos de transação e, portanto, no grau de governança. Os impostos em cascata, como o COFINS e CPMF, encarecem a compra em conjunto, dificultando sua implementação. Isto ocorre, pois quando a associação faz a fatura para os seus membros das mercadorias compradas em conjunto, deve pagar essas contribuições sobre os valores das notas fiscais, mesmo sem adicionar valor aos preços, o que encarece os custos da organização. Apesar da mudança na legislação do PIS, no final de 2002, que elimina sua cumulatividade, isso não foi o suficiente para alterar essa situação, pois este imposto tinha uma participação pequena em relação ao COFINS.

Segundo o presidente da Rede Econômica, os grandes atacadistas, apesar de pagarem estas contribuições, conseguem vender as mercadorias a um valor menor do que as associações obteriam através da compra em conjunto. Os atacadistas adquirem descontos maiores das fábricas devido ao maior volume transacionado e, ainda, têm preferência na compra com grandes descontos oferecidos para completar as quotas mensais de venda dos fornecedores.

Saes (2000) cita, ainda, que custos de transação podem incentivar a formação de organizações como forma alternativa de governança, se houver redução dos custos pertinentes em relação às aquisições individuais. Esta economia pode ser alcançada, segundo a autora, pela coordenação da compra de bens ou serviços necessários para a 
atividade. Na rede Econômica, a coordenação das negociações não reduziu os preços efetivos dos produtos adquiridos, pois, em contrato com os fornecedores fidelizados, está explicito que os preços praticados serão os de mercado. Contudo, a taxa cobrada desses fornecedores permite cobrir os custos com da associação, para cerca de $80 \%$ dos associados. Além disso, esta coordenação permite obtenção de descontos para os produtos em promoção que aparecem nos encartes, devido ao aumento do volume comercializado.

A coordenação permite, ainda, a realização, editoração e impressão dos encartes, pois o custo unitário diminui muito com o aumento do volume. As redes, entretanto, adotam estratégias distintas quanto ao custeio. A rede Economize cobra dos fornecedores o espaço nos encartes para a apresentação dos produtos em promoção. Já a rede Econômica rateia, proporcionalmente ao número de encartes adquiridos pelos membros, os seus custos, sem ônus, portanto, para o fornecedor. Contudo, neste último caso, os desembolsos com os encartes são compensados pelas as taxas de fidelização.

\subsection{As redes como ações coletivas}

As redes em estudo podem ser classificadas como ações coletivas, pois, como visto no item 2.4.1, essas ações buscam alcançar objetivos em comum, que não podem ser conseguidos individualmente e existe a necessidade de esforços coordenados. Os membros dessas redes organizaram-se em associações, uma estrutura formal, realizam ações coordenadas e visam obter benefícios particulares que individualmente não teriam, como a confecção de tablóides ou encartes, melhores condições de negociação com os fornecedores, entre outros, por terem separadamente um volume de compra pequeno.

Além disso, essas redes são grupos de adesão voluntária em que os membros se beneficiam mutuamente da divisão dos custos e da obtenção dos benefícios, seu tamanho (número de associados) é escolhido endogenamente e há mecanismos de cobrança de taxas e de exclusão aos que não estão associados (ou seja, fornecem bens de clube). Desta forma, essas associações são consideradas como clubes, neste estudo. 
Entre as ações das redes, o programa de fidelização com os fornecedores pode ser considerado um benefício de clube por ser não-rival, a sua utilização por um associado não reduz a disponibilidade para os demais, e exclusivo, visto que é possível afastar os não associados. A publicidade conjunta realizada em rádios, por exemplo, também é exemplo de benefícios de clube proporcionados pela associação. A propaganda favorece todos os associados sem rivalidade, porém beneficia apenas aos supermercados pertencentes à rede.

O problema do carona, apontado por Olson (1999), também pode estar presente nesse tipo de organização, dependendo da sua forma de organização. A rede Economize, por exemplo, teve, no início de seu funcionamento, divergências internas, pois os supermercados maiores (com maior número de lojas e volume de compra) sentiam-se prejudicados em relação aos menores, visto que contribuíam mais para volume comercializado pela associação e arcavam com as maiores despesas. O sistema utilizado neste período acabava favorecendo, de certa forma, os menores, pois obtinham as mesmas vantagens da compra em conjunto dos grandes, preços menores e melhores formas de pagamento, e contribuíam menos com as despesas da associação. Desta forma, os maiores supermercados desligaram-se da associação. Esse sistema foi modificado depois da reestruturação causada pela dívida com a Receita Federal e, atualmente, como já citado no item 5.2.1., adotam um sistema semelhante ao da Rede Econômica.

A rede Econômica, visando eliminar o problema do carona em ações coletivas, utiliza um sistema que beneficia aqueles que mais se utilizarem os fornecedores fidelizados e repartem igualmente os custos fixos da associação, como apresentado no item 5.2.1. Desta forma, os associados menos participantes são prejudicados, pois arcam com parte dos custos sem receber os benefícios da associação.

Sandler (1995) cita quatro aspectos importantes para que uma ação coletiva tenha sucesso que podem ocorrer separadamente ou de forma conjunta (item 2.4.3). Nas associações estudadas ficam evidentes três desses aspectos. 
Segundo o autor, a ação coletiva deve prover benefícios casados que sejam privados ou passíveis de exclusão. Os tablóides são um bom exemplo. Dentro das associações as promoções existentes nos tablóides podem ser consideradas como benefícios coletivos (não-rivais e não-exclusivos), pois são disponíveis para todos os membros, uma vez negociados os descontos com os fornecedores. Porém, esses abatimentos são concedidos pelos fornecedores baseados em um volume maior de compras da rede, que por sua vez espera vender mais através da propaganda nos tablóides, por exemplo.

Porém, os associados só têm a possibilidade de realizar os tablóides de forma coletiva, porque individualmente seu custo é proibitivo. Esses tablóides são benefícios passives de exclusão, uma vez que se não forem pagos por um membro, este não o recebe. Neste exemplo, a associação fornece produtos casados, pois os descontos obtidos com os fornecedores estão vinculados ao aumento de venda e este aumento somente se efetiva com a divulgação pelos tablóides. Isto incentiva os associados a adquirirem esses encartes, reduzindo seus custos unitários, tornando viável sua impressão e a realização de promoções. Portanto, o benefício coletivo (dentro da associação) - desconto para a promoção - só ocorre com um benefício de clube, execução dos tablóides, incentivando os associados a investir.

Mecanismo de exclusão é outro aspecto apontado por Sandler (1995) e encontrado na associação. A utilização de uma bandeira comum entre os supermercados associados pode ser considerada como um desses mecanismos. A publicidade vinculada pelos associados, por exemplo, serve apenas para aqueles que adotam a mesma bandeira. O programa de fidelidade beneficia apenas aos membros da associação. Desta forma, os esforços das associações restringem-se aos seus membros. Dentro da associação, também existem mecanismos de exclusão, por exemplo, os tablóides apontados anteriormente.

As interações repetidas para a formação de reputação entre os participantes, também citada por Sandler (1995), são outro aspecto igualmente importante para o 
sucesso de uma ação coletiva e que ocorre nas redes. A formação de reputação, ainda, como apontado por Nassar (2001), reduz os custos de negociação internos por diminuir a assimetria de informação e a incerteza. Assim, atenua os custos organizacionais promovendo a ação coletiva.

Na rede Econômica, são realizadas reuniões semanais para resolver questões referentes à associação e fazer os pedidos. Na rede Economize, essas reuniões são mensais. Nessas reuniões, segundo o presidente da rede Econômica, além das decisões relacionadas às questões da associação, também ocorrem trocas de experiência entre seus membros, o que colabora na melhoria da administração dos negócios.

Porém, a compensação favorável dos agentes dominantes também é apontada por Sandler (1995) como um aspecto importante para que haja a ação coletiva, ocorre apenas com os benefícios ordinários das associações. Seus presidentes e diretores não têm vantagens, pelo menos financeiramente, em relação aos demais associados, pois não recebem salários ou outros benefícios extras das associações. Segundo ambos os presidentes das associações em estudo, o fato de estarem à frente da associação representa maior carga de trabalho.

O papel do empreendedor na ação coletiva, destacado por Olson (1999), portanto, fica evidente nesses casos em estudo, visto que os membros que participam da administração não terem benefícios especiais. Segundo o autor, o empreendedor pode ser incentivado a agir quando sua ação traz ganhos tanto a grupo quanto a si mesmo. No caso da Rede Econômica, por exemplo, o atual presidente foi responsável por iniciar e administrar a associação, apesar do aumento da carga de trabalho (além de administrar sua loja, resolvia questões da associação), visando obter os benefícios da ação.

Outro aspecto comentado por Olson (1999) relaciona-se aos custos administrativos das ações coletivas. Segundo o autor, quanto maior o grupo, maiores serão os custos da organização. Nassar (2001) complementa afirmando que os grupos pequenos possuem menores problemas entre os membros e a gerência em relação aos grandes grupos. As redes estudadas são grupos pequenos e possuem estruturas 
administrativas e físicas enxutas. Atualmente, a rede Economize, com oito associados, conta com apenas um funcionário que se dedica a assuntos administrativos e financeiros, e uma sala alugada. A rede Econômica, com 12 associados, possui quatro funcionários e um galpão alugado em Limeira. Em ambas as redes, a participação dos membros na administração é grande, o que ajuda a reduzir os seus custos.

Essa característica, baixos custos operacionais, é importante para este tipo de organização, pois, como apontado por Nassar (2001), a contribuição voluntária para uma ação coletiva só é racional se os benefícios obtidos com ela são maiores do que seus custos e, de acordo com Olson (1999), estas despesas elevariam as barreiras a ser transposta antes que o benefício fosse obtido.

Outra vantagem, apontada por Nassar (2002), para grupos pequenos, em relação aos grandes, é a proximidade entre a administração e seus membros. Como já mencionado, os associados participam ativamente na administração. $\mathrm{Na}$ rede Econômica, por exemplo, foi adotado um sistema de rodízio, no qual grupos de três ou quatro pessoas ficam responsáveis pelo atendimento aos fornecedores, negociações e realização de encartes (item 5.2.1). Iniciativas deste gênero permitem que ações de tipo I e II sejam tomadas em detrimento de ações do tipo III, que requerem mecanismos de compensação para que a ação ocorra, devido ao comprometimento direto da administração com seus atos.

Entretanto, essa mesma característica pode trazer problemas à associação. Na rede Economize, por exemplo, quando os associados maiores sentiam-se prejudicados pelo sistema de rateio de custos utilizado, não foi possível implementar mudanças, pois, para tanto, teriam que adotar medidas de ações do tipo III (prejudicando os menores, segundo seus pontos de vista, por terem que arcar com maiores despesas da organização). Por este motivo, o sistema não foi alterado, o que gerou a saída dos maiores membros, prejudicando a associação como um todo.

Outro aspecto citado por Nassar (2001) refere-se à rivalidade entre a associação e seus membros. Segundo o autor, a organização não deve possuir a mesma função dos 
agentes que a forma para não haver rivalidade entre eles. No caso em estudo, a função da associação é complementar a dos seus membros. O primeiro negocia com os fornecedores e realizar propaganda, não rivalizando com a função dos supermercados, que é disponibilizar produtos e serviços ao consumidor final.

Neste tipo de organização pode ocorrer concorrência direta entre os associados se as lojas forem muito perto umas das outras, o que possibilitaria conflitos internos, pela redução, por exemplo, da eficiência das promoções. Para evitar isso, a Rede Econômica, na sua formação, optou por escolher lojas que não fossem competidoras, como citado pelo seu presidente. $\mathrm{O}$ mesmo pode-se observar com a rede Economize, que atua em diversas cidades e, em Pracicaba e Rio Claro, onde a rede tem mais de uma loja, estas não são próximas umas das outras.

Segundo o presidente da rede Econômica, é consenso que a associação manteve a competitividade. Antes da fundação da associação não havia supermercados como Enxuto, BIG, SempreVale, Paulistão atuando na cidade de Limeira. Mesmo com a entrada desses novos concorrentes, os associados conseguiram manter o nível de vendas e alguns ampliarem o negócio, o que, segundo o presidente, já é um grande feito. Ele cita o caso de dois associados que saíram, sendo que um, posteriormente, vendeu a loja a outro associado, e o segundo retornou à associação, como um fato de motivação para os associados.

A realização de propaganda conjunta é uma das grandes vantagens das associações, pois, como já observado, individualmente elas não teriam condições de realizar os encartes, devido ao baixo volume e altos custos. A propaganda em rádio e jornais também seria inviável por ser muito cara, mas, se dividida entre as lojas, torna-se mais acessível e, pelo programa de fidelização que não seria possível sem a associação, fica praticamente de graça.

Outra vantagem é a troca de experiências entre os associados, que melhora a administração dos seus estabelecimentos. As vantagens apontadas, portanto, foram: 
negociação em conjunto, que permite a taxa de fidelização, propaganda conjunta, o cartão de crédito e a troca de experiências entre os associados. 


\section{CONCLUSÕES}

O presente trabalho tem como objetivo realizar um estudo exploratório sobre as razões da formação das associações de redes independentes e como elas podem ser uma estratégia para melhorar a competitividade de pequenos supermercados frente às principais mudanças que ocorreram no setor supermercadista nos últimos anos. A hipótese central do estudo constitui-se em que a formação dessas associações é uma estratégia dos pequenos supermercados para se tornarem mais competitivos no mercado varejista. A abordagem teórica da Organização Industrial possibilita obter uma visão geral do setor supermercadista e as teorias da Economia dos Custos de Transação e da Ação Coletiva permitem entender os benefícios e limitação da criação das associações. A natureza deste estudo é, portanto, analítica, uma vez que não utiliza nenhum modelo estatístico para a análise dos dados apresentados.

O setor supermercadista tem relevante participação na economia brasileira, representa cerca de $6 \%$ do PIB brasileiro e destaca-se na venda de bens de consumo diário, respondendo a mais de $86 \%$ do volume total comercializado no final da década de 90. Entre as maiores empresas do setor, houve um processo de internacionalização do capital. Em 1991, das sete maiores firmas, apenas duas possuíam capitais estrangeiros. Dez anos mais tarde, somente uma firma não pertence ou não possuí sócio internacional.

Para a melhor compreensão das condições básicas do setor, deve-se observar que o principal serviço oferecido pelo supermercado consiste em disponibilizar uma grande variedade de produtos, principalmente de consumo diário, em apenas um local, proporcionando comodidade, praticidade e economia de tempo ao consumidor.

A oferta desses serviços tem como principais características a predominância da 
baixa especificidade da mão de obra e da tecnologia empregada, possuírem grande gama de fornecedores com ampla variedade de tamanho e poder de mercado.

Do lado da demanda, há amplo número de fregueses que compram pequenos volumes, em relação ao faturamento do estabelecimento, com alta freqüência e de forma recorrente. Além disso, a demanda dos clientes por qualidade, variedade e quantidade está diretamente relacionada a sua renda. Outra característica que o setor possui é a presença de economias de escala e de escopo.

A estrutura de mercado brasileiro do setor é classificada como um oligopólio diferenciado com franja neste estudo, tendo em vista que as quatro maiores empresas participavam, em 2000, com cerca de $37 \%$ do faturamento bruto do setor e existiam cerca de 10 mil firmas, segundo classificação do IBGE. Ademais, a participação das maiores firmas em relação ao faturamento bruto de setor possui tendência de aumento nos últimos anos, mas, ainda, não chegou aos níveis dos países desenvolvidos como França, Reino Unido ou Alemanha.

Ainda, como o setor tem economias de escala, espera-se, portanto, que as empresas líderes pertencentes ao oligopólio apresentem custos menores aos da franja. Os custos inferiores das grandes firmas podem ser evidenciados pela utilização mais eficientes de certos insumos. Enquanto as quatro maiores firmas em faturamento obtinham 35,5\% da receita bruta do setor em 2001, eles possuíam apenas $13 \%$ das caixas registradoras, $17,2 \%$ da área de vendas, $1,4 \%$ do número de lojas e 19,4\% do total de funcionários.

Existe no setor, também, a busca de diferenciação, na tentativa de fidelizar seus clientes, aumentando, assim, o poder de mercado, já que os serviços prestados pelos estabelecimentos são vistos pelos consumidores como bons substitutos.

As baixas barreiras à entrada são outra característica da estrutura do mercado. Estas estão relacionadas: (i) aos custos irrecuperáveis (sunk costs), como gastos com publicidade; (ii) vantagens das empresas já estabelecidas (como conhecimento do 
mercado); (iii) contratos com fornecedores; (iv) escolha da localização e barreiras legais ou regulatórias; e (v) retaliação dos competidores instalados.

Entretanto, essas barreiras podem ser reduzidas adquirindo-se estabelecimentos já existentes, ou pela utilização de estruturas que a empresa já possua, como contratos com fornecedores, uso da mesma publicidade de outros estabelecimentos etc. Ainda, as tecnologias empregadas são relativamente pouco especificas e possuem mercado secundário. A implantação de novas lojas, também, possui custos pequenos e é considerada "tempestiva".

As economias de escala e as baixas barreiras à entrada encorajam as empresas a investirem em sua expansão, o que por sua vez é uma das causas do aumento de concentração no setor. Desta forma, observa-se que uma característica da estrutura de mercado (economias de escala e baixas barreiras à entrada), incentiva uma conduta das firmas (investimento em expansão), que por sua vez volta a influenciar a estrutura (grau de concentração do mercado).

As reduzidas barreiras de entrada, juntamente com a entrada "tempestiva" e a presença de uma franja, fazem com que o exercício de poder de mercado sobre seus consumidores seja limitado. Isso ocorre porque possibilita a entrada de novos concorrentes, o que aumenta a oferta de serviço e a rivalidade na região. E, como o preço é um importante atributo na escolha da loja, restringem o exercício de poder de monopólio.

A conduta das firmas também é influenciada pela mudança nos hábitos do consumidor. No período de inflação elevada, compravam-se volumes maiores e com menos frequiência para reduzir a perda do valor do salário. Isso incentivava a construção de hipermercados, locais onde se encontra grande variedade e quantidade de produtos. Com a estabilização econômica, foi possível fazer compras menores e com mais freqüência sem grandes perdas no valor do salário. Isso estimulou o investimento em lojas de vizinhança, mais próximas ao consumidor, e a redução na área de vendas dos estabelecimentos, como visto na Figura 12 do item 5.1.3. 
As políticas públicas interferem diretamente no setor, seja pelo lado da oferta de produtos e serviços, seja por sua demanda. $\mathrm{O}$ primeiro ocorre pela regulamentação, pelas políticas macroeconômicas, como controle de preço e impostos. E a demanda é influenciada pela renda da população.

A partir dos anos 90, e principalmente após a sua segunda metade, o setor supermercadista passou por profundas mudanças. Alterações no ambiente, como a estabilização da economia brasileira, resultaram inicialmente em aumento no consumo de alimentos, provocaram modificação no comportamento do consumidor e redução nos ganhos financeiros das firmas. A abertura da economia juntamente com a saturação dos mercados nos países desenvolvidos e aumento do consumo, levou à entrada de novas firma multinacionais no País.

Conjuntamente, o crescimento do número de lojas, aumento da concentração e diminuição dos custos operacionais resultaram em incremento da rivalidade no setor e na redução do faturamento médio por loja e área no período estudado. Tais fatos interferem novamente na atuação das firmas do setor.

Com essas alterações no ambiente competitivo, as empresas precisaram adotar novas condutas para se adaptarem a nova realidade, como a redução de custos operacionais. As grandes firmas, visando ganhos de escala, investiram na expansão com compra de outros supermercados e inauguração de lojas. Também adotaram novas tecnologias e buscaram nichos de mercado. As pequenas empresas, com menor poder de investimento, buscaram, igualmente, utilizar novas tecnologias, mas de forma menos intensiva, procurar nichos de mercado e realizar associações ou contratos com atacadistas.

Portanto, em meio às estratégias que as pequenas empresas podem utilizar para aumentarem sua competitividade, como citado anteriormente, encontra-se a criação de associações. Através do estudo de duas destas organizações da região de Piracicaba, buscou-se observar como esta estratégia tem apresentado vantagens aos associados e quais são seus desafios. 
Observou-se que a constituição de uma associação trouxe benefícios aos supermercados, devido a algumas economias de escala e redução nos custos de transação. Mas também pode ser restrita por problemas de ação coletiva e do Ambiente Institucional. As associações escolhidas apresentam características que possibilitam verificar ambos os casos.

A redução nos custos de transação ocorre pela diminuição da necessidade de várias negociações entre o fornecedor e cada associado. Além disso, são realizados contratos de um ano, o que geralmente não acontece individualmente com as lojas, diminuindo a incerteza do fornecedor quanto à venda de seus produtos. Com essas reduções, as associações podem exigir que os vendedores repassem a ela parte destes ganhos. Isto ocorre por meio da taxa de fidelização. Desta forma, parte ou, em alguns casos, todos os gastos dos associados com a entidade são cobertos por esta taxa.

A taxa de fidelização serve, também, como incentivo à utilização da associação, já que seu ganho está relacionado à compra dos fornecedores fidelizados. Isso ajuda a reduzir alguns problemas observados em ações coletivas, como o "carona". Quando a rede Economize cobrava mais dos que mais compravam pela associação, desestimulava o seu uso pelos associados maiores e beneficiava os supermercados menores, que não queriam mudar o sistema e agiam como "carona". Como os pequenos eram maioria, o sistema não foi modificado, ocasionando a saídas dos associados maiores.

Desta forma, pelas características das ações coletivas, a figura do "carona" fez com que essas organizações tivessem que se compor de tal forma que reduzissem os danos gerados por esse comportamento.

Ainda, outra vantagem com a associação é que, em certas ocasiões, ela consegue comprar os produtos a preços menores. Isso ocorre quando realiza promoções e, portanto, adquire volumes maiores, ou quando obtém cargas fechadas e consegue descontos pela redução nos custos do frete.

Os associados também têm a possibilidade de oferecer aos seus clientes mais 
serviços como um cartão que permite financiar as compras. Outro exemplo de benefício é a confecção de encartes ou tablóides. Separadamente, o custo é muito alto devido ao pequeno número impresso, mas conjuntamente o dispêndio individual do folheto fica menor, viabilizando sua edição. Assim, os associados conseguem divulgar suas lojas e promoções.

Igualmente, deve-se observar que as associações estudadas proporcionam trocas de informações entre os seus participantes. Isso possibilita, pelo compartilhamento de experiências, melhorar a administração das lojas.

Porém, características do Ambiente Institucional, como a existência de impostos em cascata, limitam a atuação dessas associações. Estes impostos tornam inviáveis as compras em conjunto devido ao encarecimento dos custos dessas organizações. Normalmente, segundo os dirigentes das associações estudadas, os descontos obtidos pelas compras conjuntas são menores que os impostos pagos ao emitir novas faturas pela associação ao redistribuir o produto. Isto ocorre, pois, mesmo adquirindo em grupo, não conseguem o mesmo nível de desconto que as redes maiores e os atacadistas, já que as organizações estudadas são formadas por lojas pequenas.

Portanto, devido às condições básicas e à estrutura de mercado do setor supermercadista, houve aumento de concentração e de rivalidade no setor, após mudanças na política macroeconômica e ro hábito de consumo. Como os supermercados menores ficaram menos competitivos com estas transformações, alguns buscaram estratégias para permanecerem no mercado, entre elas encontra-se a formação de associações. Segundo o presidente de uma das associações, a estratégia adotada pelos supermercados é interessante, pois seus associados permaneceram no mercado mesmo com a inauguração de supermercados de porte maiores.

No entanto, como este trabalho tem caráter exploratório, é interessante a realização de estudos mais abrangentes, comparando lojas que adotaram este sistema de associação com estabelecimentos que não o adotaram e, para tanto, há a necessidade de se realizar um maior número de entrevistas. Além disso, pode-se realizar um estudo que 
compare as vantagens e limitações da formação de associações com as firmas que fazem contratos com atacadista nos moldes da IGA e da Rede Smart. 


\section{REFERÊNCIAS BIBLIOGRÁFICAS}

ASSOCIAÇÃO BRASILEIRA DA INDÚSTRIA ELÉTRICA E ELETRÔNICA ABINEE. http://www.abinee.org.br/abinee/decon/decon15.htm (11 jul. 2002)

ASSOCIAÇÃO BRASILEIRA DE SUPERMERCADOS - ABRAS. 40 Anos de supermercados no Brasil. São Paulo, 1993. 186p.

ASSOCIAÇÃO BRASILEIRA DE SUPERMERCADOS. Economia / Pesquisa. http://www.abrasnet.com.br/index_rank.htm (20 mar. 2002)

ASSOCIAÇÃO NACIONAL DOS FABRICANTES DE VEÍCULOS AUTOMOTORES - ANFAVEA. Anuário Estatístico. http://www.anfavea.com.br/ anuario.htm (11 jul. 2002)

AUTOMAÇÃO de retaguarda define o sucesso da loja. Supermercado Moderno, v.27, n.1, p.32-38, jan. 1996.

AZEVEDO, P.F. Integração vertical e barganha. São Paulo, 1996. 219p. Tese (Doutorado) - Faculdade de Economia e Administração, Universidade de São Paulo.

BERTASSO, B.F. O consumo alimentar em regiões metropolitanas brasileiras: análise da pesquisa de orçamentos familiares / IBGE - 1995/96. Piracicaba, 2000. 109p. Dissertação (Mestrado) - Escola Superior de Agricultura "Luiz de Queiroz", Universidade de São Paulo.

BLECHER, N. A ditadura do varejo. Exame, v.36, n.12, p.45-52, jun. 2002a.

BLECHER, N. Eu tenho a força. Exame, v.36, n.12, p.53-55, jun. 2002 b. 
BRASIL. Leis, decretos, etc. Lei $\mathbf{n}^{\mathbf{0}} \mathbf{8 8 8 4}$ de 11 de junho de 1994. http//www.senado.gov.br (19 mar. 2003)

BRASIL. Ministério da Fazenda. Secretaria de Acompanhamento Econômico. Guia para análise econômica de atos de concentração. http://www.fazenda.gov.br/ seae/documentos/guial.html (15 maio 2001)

BRITO, D. Qual o formato correto de sua loja. SuperHiper, v.24, n.77, p.74-77, set. 1998.

CARLTON, D.W.; PERLOFF, J.M. Modern industrial organization. 2.ed. New York: HaperCollins College Publushers, 1994. 973p.

CAVAlCANTE, L.B; TEIXEIRA,C.P.; CONSIDERA, C.M. Parecer n⿳025/COGSE /SEAE/MF. Brasília: Secretaria de Acompanhamento Econômico, jan. 2001a. http://www.fazenda.gov.br/seae (20 maio 2001)

CAVAlCANTE, L.B.; TEIXEIRA,C.P.; CONSIDERA, C.M. Parecer n097/COGSE /SEAE/MF. Brasília: Secretaria de Acompanhamento Econômico, mar. 2001b. http://www.fazenda.gov.br/seae (20 maio 2001)

CHIARA, M. de. Consumidor é quem ganha com disputa. O Estado de São Paulo. Caderno de Economia, São Paulo, 24 jul. 2000a. p.B-6.

CHIARA, M. de. Concentração do varejo preocupa indústria. O Estado de São Paulo. Caderno de Economia, São Paulo, 24 jul. 2000b. p.B-6.

CHIARA, M. de. Redes médias de supermercado ganham espaço, revela pesquisa. O Estado de São Paulo. Caderno de Economia, São Paulo, 22 abr. 2002. http://www.estado.com.br/editoriais/2002/04/22/eco045.html (22 abr. 2002)

COMO atrair o consumidor com a moeda estável. Supermercado Moderno, v.26, n.3, p.120, mar. 1995. 
CONNOR, J.M. Concentration and mergers in U.S. wholesale grocery markets. Lafayette: Purdue University, June 1997. 67p. (Staff Paper, 97-09)

CONNOR, J.M. Evolving research on price competition in the grocery retailing industry: an appraisal (compact disc). In: CONGRESSO BRASILEIRO DE ECONOMIA E SOCIOLOGIA RURAL, 37., Foz de Iguaçu, 1999. Anais. Brasília: SOBER, 1999.

CONNOR, J.M.; SCHIEK, W.A. Food processing: an industrial powerhouse in transition. 2.ed. New York: John Wiley \& Sons, 1997. 665p.

COTTERILL, R.W. Continuing concentration in food industries globally: strategic challenges to an unstable status quo. Storrs: University of Connecticut, Oct. 1999. 28p. (Research report, 49)

CRESCENDO em todas as direções. Supermercado Moderno, v.31, n.11, p.28-34, nov. 2000.

CYRILLO, D.C. O papel dos supermercados no varejo de alimentos. São Paulo: IPE, 1987. 198p. (Série Ensaios Econômicos, 68)

DEMARCHI, C.; TUSZEL L. O poder concentrado das gôndolas. Gazeta Mercantil. Caderno de Negócios, São Paulo, 06 nov. 2000. p.6.

DIB, J.A. Efficient Consumer Response (ECR): uma estratégia para o varejo de bens de consumo de massa. Revista de Administração, v. 23, n.2, p.14-22, abr./jun. 1997.

DOBSON, P.R.; WATERSON, M. Countervailing power and consumer price. The Economic Journal, v.107, p.418-430, Mar. 1997.

ESSIG, M. Purchasing consortia as symbiotic relationships: developing the concept of "consortium sourcing". European Journal of Purchasing and Supply Management, v.6, n.1, p.13-22, 2000. 
FARINA, E.M.M.Q. Reflexões sobre desregulamentação e sistemas agroinduistriais: a experiência brasileira. São Paulo, 1996. 156p. Tese (Livre-Docência) - Faculdade de Economia, Administração e Contabilidade, Universidade de São Paulo.

FARINA, E.M.M.Q. Organização industrial no agribusiness. In: ZYLBERSZTAJN, D.; NEVES, M.F. (Org.). Economia e gestão dos negócios agroalimentares: indústria de alimentos, indústria de insumos, produção agropecuária e distribuição. São Paulo: Pioneira, 2000. cap.3, p.39-79.

FARINA, E.M.M.Q.; REARDON, T. Agrifood grades and standards in the extended mercosur: their role in the changing agrifood system. American Journal of Agricultural Economics, v.82, n.5, p.1170-1176, 2000.

FARINA, E.M.M.Q.; AZEVEDO, P.F. de; SAES, M.S.M. Competitividade: mercado, estado e organizações. São Paulo: Editora Singular, 1997. 285p.

FERGUSON, C.E. Microeconomia. Rio de Janeiro: Forense Universitária, 1996. 610p.

FERREIRA, M.L.; CAVALCANTE, L.B.; GOCINHO, C.V.H.; RAMOS, M.M.; TEIXEIRA, C.P.; CONSIDERA, C.M. Parecer $\mathbf{n}^{\mathbf{2} 243 / C O G S E / S E A E / M F}$ Brasília: Secretaria de Acompanhamento Econômico, jul. 2001. http://www.fazenda.gov.br/seae (15 abr. 2002)

GONÇALVES, J. O varejo no século XXI. Superhiper, v.26, n.304, p.10-19, dez. 2000.

GREMAUD, A.P.; VASCONCELlOS, M.A.S.; TONETO JÚNIOR; R. Economia brasileira contemporânea. São Paulo: Atlas, 2002. 626p.

GURDJIAN, P.; KERSCHBAUMER, G.; KLIGER, M.; WATEROUS, J. Bagging Europe's groceries. McKinsey Quarternary, n.2, p.68-75, 2000. 
HOFFMANN, R. Elasticidades-renda das despesas e do consumo físico de alimentos no Brasil metropolitano em 1995-96. Agricultura em São Paulo, v.47, n.1, p.111-122, 2000 .

INCANDELA, D.; McLAUGHLIN, K.L.; SHI, C.S. Retailers to the word. McKinsey Quaternary, n.3, p.84-97, 1999.

INSTITUTO BRASILEIRO DE GEOGRAFIA E ESTATÍSTICA - IBGE. http://www.ibge.gov.br (10 dez. 2002)

$\mathrm{KOCH}$, J.V. Industrial organization and prices. 2.ed. Englewood Cliffs: PrenticeHall Inc., 1980. 504p.

KPMG. Pesquisa de fusões e aquisições: transações realizadas no Brasil, 2001 - quarto trimestre e acumulado. http//www.kpmg.com.br (20 set. 2002)

KUMAR, N. The revolution in retailing: from market driven to market driving. Long Range Planning, v.30, n.6, p.830-835, 1997.

LAZZARINI, S.G. Estudo de caso para fins de pesquisa: aplicabilidade e aplicações do método. In: FARINA, E.M.M.Q. (Coord.). Estudo de caso em agribusiness. São Paulo: Pioneira, 1997. cap.1, p.9-23.

LEENDERS M.R.; FEARON, H.E. Purchasing and supply management. Chicago: Irwin McGraw-Hill, 1997. 683p.

LEPSCH, S.L. Precificação em supermercados: um estudo exploratório junto a vinte empresas brasileiras. Piracicaba, 1999. 89p. Dissertação (Mestrado) - Escola Superior de Agricultura "Luiz de Queiroz", Universidade de São Paulo.

LUKIANOCENKO, M. A reação dos pequenos supermercados. Superhiper, v.27, n.315, p.10-17, nov. 2001. 
MARQUES. P.V. Noções básicas de concentração de mercados. 2.ed. Piracicaba: ESALQ, Depto. de Economia e Sociologia Rural. 1992. 11p. (Série didática, 82)

MORAES, M.A.F.D. de. A desregulamentação do setor sucroalcoolerio do Brasil. Americana, Americana: Caminho Editorial, 2000. 238p.

NASSAR, A.M. Eficiência das associações de interesse privado nos agronegócios brasileiros. São Paulo, 2001. Dissertação (Mestrado) - Faculdade de Economia, Administração e Contabilidade, Universidade de São Paulo.

NEVES, M.F. Um modelo para planejamento de canais de distribuição no setor de alimentos. São Paulo, 1999. 193p. Tese (Doutorado) - Faculdade de Economia, Administração e Contabilidade, Universidade de São Paulo

OLSON, M. A lógica da ação coletiva: os benefícios públicos e uma teoria dos grupos sociais. Trad. de F. Fernandez. São Paulo: EDUSP, 1999. 201p.

PERRY, M.K. Vertical integration: determinants and effects. In: SCHMALENSEE, R.; WILLING, R.D. (Org.). Handbook of industrial organization. Amsterdã: Elservier Science Publishers, 1992. cap.4, p.183-255.

POMPEU, R.B. Ações coletivas na citricultura: comparação entre as associações de produtores e das indústrias. Piracicaba, 1997. 131p. Dissertação (Mestrado) Escola Superior de Agricultura "Luiz de Queiroz", Universidade de São Paulo.

REBOUÇAS, L. Vida de nanico. Exame, v.36, n.12, p.45-52, jun. 2002.

RIBEIRO, A.R.B. Abastecimento de madeira para a produção de celulose: uma aplicação da economia dos custos de transação. Piracicaba, 116p. 1998. Dissertação (Mestrado) - Escola Superior de Agricultura "Luiz de Queiroz", Universidade de São Paulo. 
ROJO, F.J.G. Supermercados no Brasil: qualidade total, marketing de serviços, comportamento do consumidor. São Paulo: Atlas, 1998. 175p.

SAES, M.S.M. Organização e instituições. In: ZYLBERSZTAJN, D.; NEVES, M.F. (Org.). Economia e gestão dos negócios agroalimentares: indústria de alimentos, indústria de insumos, produção agropecuária e distribuição. São Paulo: Pioneira, 2000. cap.8, p.165-186.

SANDLER, T. Collective Action: theory and application. Ann Arbor: The University of Michigan Press, 1995. 237p.

SANTOS, A.M.M.; GIMENEZ, L.C.P. Reestruturação do comércio varejista e de supermercados. http://www.bndes.gov.br/publica/Bnset/set903.exe (12 abr. 2001)

SCHERER, F.M. Industrial market structure and economic performance. Chicago: Rand McNally College Publishing Company, 1970. 576p.

SCHERER, F.M.; ROSS, D. Industrial market structure and economic performance. Boston: Houghton Mifflin Company, 1999. 713p.

SEGRE L.M.; BASTOS, R.M. Modernização produtiva nos supermercados: a adoção de tecnologias de informação e comunicação. Revista de Administração, v.35, n.4, p.72-83, out./dez. 2000.

SESSO FILHO, U.A. Crescimento e desempenho de redes de supermercados na década de 90. In: ÂNGELO, C.F. de; SILVEIRA, J.A.G. da (Coord.). Varejo competitivo. São Paulo: Atlas, 2002. cap.1, p.21-44.

SESSO FILHO, U.A. Estratégias de comercialização do hortifrútis no setor supermercadista: estudo de casos. Piracicaba, 1999. 80p. Dissertação (Mestrado) Escola Superior de Agricultura "Luiz de Queiroz", Universidade de São Paulo. 
SILVA, G.M.O; FAMÁ, R. O recente movimento de fusões e aquisições no setor de supermercados: possíveis causas e conseqüências (compact disc). In: SEMEAD JR., 1., São Paulo, 1999. Anais. São Paulo: Faculdade de Economia Administração e Contabilidade, Universidade de São Paulo, 1999.

SILVEIRA, J.A.; LEPSCH S.L. Alterações recentes na economia do setor supermercadista brasileiro. Revista de Administração, v.32, n.2, p.5-13, abr./jun. 1997.

SOUZA, W. de. Análises especiais: novas tendências. Revista Superhiper, v.28, n.370, p.8-27, maio 2002b.

SOUZA, W. de. As expectativas dos supermercadistas para 2002/2003. Revista Superhiper, v.28, n.370, p.8-27, maio 2002a.

SUTTON, J. Sunk costs and market structure. Cambridge: The MIT Press, 1992. $577 \mathrm{p}$.

TAKAOKA, H.; NAVAJAS, P.F. Intercâmbio eletrônico de dados (EDI): vantagens para o varejo. Varejo competitivo. São Paulo: Atlas, 1997. v.2. p.19-34.

VARIAN, H.R. Microeconomia: princípios básicos. Rio de Janeiro: Campus, 1994. $710 \mathrm{p}$.

WILDER, A.; SESSO FILHO, U.A., Distribuição de alimentos: transformação na década de 90. Informações FIPE, n.257, p.22-27, fev. 2002.

WILLIAMSON, O. The economic institutions of capitalism New York. The Free Press, 1987. 450p.

WILLIAMSON, O. The mecanisms of governance. New York: Oxford University Press, 1996. 379p. 
YIN, R.K. Case study research: design and methods. California: Sage Publications, 1990. 165 p.

ZYLBERSZTAJN, D. Estrutura de governança e coordenação do agribusiness: uma aplicação da Nova Economia das Instituições. São Paulo, 1995. 285p. Tese (Livre

- Docência) - Faculdade de Economia e Administração, Universidade de São Paulo. 
APÊNDICES 
APÊNDICE 1 - Roteiro de entrevista.

Em relação àassociação:

1) Qual a história da associação (quando e por que e como foi foi formada, por quantos integrantes)

2) Quais as mudanças sofridas pela organização em termos de ações, objetivos etc.?

3) Qual é o objetivo da associação? quais são suas ações, o que faz?

4) Qual a estrutura organizacional? (organograma)

5) Existe muita diferença entre os associados? (tamanho, volume de compra, participação na associação etc.)

6) Como se dá o processo de decisão dentro da associação?

7) Quais são as formas de contribuição dos associados, como a associação se mantém financeiramente?

8) Quais são as vantagens dos associados ao participar da associação?

9) Descrição do perfil dos membros:
a) número atual de associados
b) número de lojas
c) número de check outs por lojas médio
d) soma do faturamento dos associados

10) Quais são os serviços prestados aos associados?
a) tipos de serviços
b) participação dos serviços no faturamento

11) Como se dá a comunicação entre a associação e os associados? 
12) Como se dá a organização de campanhas, promoções etc. pela associação? Quando foi a última?

13) A Associação têm interesse de novos associados? Por quê? Quais as estratégias para consegui-los?

14) Houve saída de associados? Quais foram os motivos?

15) Quais os principais desafios (problemas, conflitos) que a associação enfrenta?

16) Quais as ações para solucionar esses desafios?

17) Como a associação tem resolvido o problema da bitributação?

18) Qual o processo de compra e distribuição dos produtos pela associação?

19) Quantos itens a associação compra regularmente?

20) Quais são os principais fornecedores da associação?

21) Qual a infra-estrutura da associação?

22) Quantos funcionários possui?

Em relação ao associado:

1) Por que resolveu associar-se?

2) Qual objetivo que pretendeu alcançar ao associar-se?

3) Os custos relativos à associação compensam as vantagens obtidas com ela? 
APÊNDICE 2 - Questionário.

\section{IMPORTANTE}

AS INFORMAÇÕES OBTIDAS PELO PRESENTE QUETIONÁRIO SÃOCONFIDENCIAIS E UTILIZADAS APENAS PARA FINS DE PESQUISA EM UMA ANÁLISE GLOBAL SE NÃO SOUBER OU NÃOESTIVER CLARA ALGUMA QUESTÃO DEIXE-A EM BRANCO.

PARTE I - CARACTERIZAÇÃO DO SUPERMERCADO

Nome do Supermercado:

Cidade: Tel:

Possui outras lojas: Não Sim, quantas:

\begin{tabular}{|c|c|c|c|c|c|c|c|}
\hline 1 & $\begin{array}{llll}\text { Quantas horas por semana a loja } \\
\text { permanece aberta? (máx } 168 \text { horas) }\end{array}$ & & & & & & \\
\hline 2 & $\begin{array}{l}\text { Qual a área de venda aproximada da loja? } \\
\left(\mathrm{m}^{2}\right)\end{array}$ & $\begin{array}{c}\text { até } \\
250 \mathrm{~m}^{2}\end{array}$ & $\begin{array}{c}251- \\
1000 \mathrm{~m}^{2}\end{array}$ & $\begin{array}{c}1001- \\
2500 \mathrm{~m}^{2}\end{array}$ & $\begin{array}{c}2501- \\
5000 \mathrm{~m}^{2}\end{array}$ & \multicolumn{2}{|c|}{$\begin{array}{l}\text { mais de } \\
5001 \mathrm{~m}^{2}\end{array}$} \\
\hline 3 & $\begin{array}{l}\text { Qual o número aproximado de produtos } \\
\text { ativos vendidos? }\end{array}$ & até 300 & $\begin{array}{l}301- \\
4.500\end{array}$ & $\begin{array}{l}4.501- \\
7.000\end{array}$ & $\begin{array}{l}7.001- \\
9.000\end{array}$ & \multicolumn{2}{|c|}{$\begin{array}{l}\text { mais de } \\
9.001\end{array}$} \\
\hline 4 & Qual o número de caixas? & até 4 & $5-9$ & $10-19$ & $20-29$ & \multicolumn{2}{|c|}{$\begin{array}{l}\text { mals } \\
\text { de } 30\end{array}$} \\
\hline 5 & $\begin{array}{l}\text { Qual foi a faturamento bruto médios } \\
\text { mensal de vendas? (mil reais) }\end{array}$ & até 50 & $51-100$ & $101-300$ & $\begin{array}{c}301- \\
500\end{array}$ & $\begin{array}{l}501- \\
700\end{array}$ & $\begin{array}{l}\text { mais } \\
700\end{array}$ \\
\hline
\end{tabular}

Enumere os itens abaixo em termos de gastos diretos do supermercado nos seguintes meios de comunicação (1 para os maiores gastos e 5 para os menores).

Caso não seja utilizado, apenas assinale se pretende ou não utilizá-lo no futuro.

\begin{tabular}{|l|l|l|l|l|}
\hline \multicolumn{2}{|l|}{} & \multirow{2}{*}{$\operatorname{Sim}$} & \multicolumn{2}{|c|}{ NÄO } \\
\cline { 4 - 5 } & & Planeja realizar & NAO planeja realizar \\
\hline 6 & Propaganda em jornais & & & \\
\hline 8 & Propaganda em TV & & & \\
\hline 9 & Propaganda em rádio & & & \\
\hline 10 & Propaganda em outdoor & & & \\
\hline
\end{tabular}


A loja possui os seguintes serviços ou produtos? Caso não haja, planeja faze-lo?

\begin{tabular}{|l|l|l|l|l|}
\hline \multirow{2}{*}{} & \multirow{2}{*}{ SIM } & \multicolumn{2}{|c|}{$\begin{array}{c}\text { Planeja } \\
\text { realizar }\end{array}$} & $\begin{array}{c}\text { NAO planeja } \\
\text { realizar }\end{array}$ \\
\hline 11 & Hortifrutis & & & \\
\hline 12 & Açougue & & & \\
\hline 13 & Frios e Laticínios & & & \\
\hline 14 & Padaria & & & \\
\hline 15 & Promotores de venda & & & \\
\hline 16 & Rotisserie & & & \\
\hline 17 & Produtos com marca própria & & & \\
\hline 18 & Programa de fidelidade (cartão) & & & \\
\hline 19 & $\begin{array}{l}\text { Sistema de integração frente } \\
\text { retaguarda }\end{array}$ & & & \\
\hline 20 & Caixas automatizados & & & \\
\hline 21 & Balanças eletrônicas & & & \\
\hline 22 & Delivery (entrega ao domicílio) & & & \\
\hline 23 & Empacotadores & & & \\
\hline 24 & Vagas para carro exclusivas para a loja & & & \\
\hline 25 & Gerenciamento de categorias (espaço) & & & \\
\hline
\end{tabular}

Para um típico recém-contratado, quantas horas de treinamento (em classe ou supervisão individual) são realizadas para as seguintes atividades:

(caso não haja o profissional, deixe em branco)

\begin{tabular}{|l|l|c|c|c|c|}
\hline & Número de horas de treinamento & $\begin{array}{c}\text { não há } \\
\text { treinamento }\end{array}$ & $\begin{array}{c}\text { até 8 } \\
\text { horas }\end{array}$ & $\begin{array}{c}\text { de 9 à 24 } \\
\text { horas }\end{array}$ & $\begin{array}{c}\text { mais de } \\
\text { 25 horas }\end{array}$ \\
\hline 26 & Caixa & & & & \\
\hline 27 & Repositor de produtos & & & & \\
\hline 28 & Repositor de FLV & & & & \\
\hline 29 & Padeiro & & & & \\
\hline 30 & Açougueiro & & & & \\
\hline 31 & Peixeiro & & & & \\
\hline 32 & Frios & & & & \\
\hline 33 & Chefes de seção & & & \\
\hline
\end{tabular}


CARACTERIZAÇÃO DO AMBIENTE OU CENTRAL DE COMPRAS

Indique nome e distância dos dois supermercados que são os principais concorrentes de sua loja.

\begin{tabular}{|c|c|c|c|c|c|}
\hline & & \multicolumn{4}{|c|}{ Concorrentes } \\
\hline & (1) ivoinc & & & & \\
\hline 35 & Distância da sua loja & Até $500 \mathrm{~m}$ & Até $2 \mathrm{~km}$ & até $5 \mathrm{~km}$ & mais de $5 \mathrm{~km}$ \\
\hline 36 & (2) Nome & & & & \\
\hline 37 & Distância da sua loja & Até $500 \mathrm{~m}$ & Até $2 \mathrm{~km}$ & até $5 \mathrm{~km}$ & mais de $5 \mathrm{~km}$ \\
\hline
\end{tabular}

Assinale, segundo a sua opinião, quais os itens em que na loja do concorrentes, acima citado, são melhores do que da sua loja.

$$
\text { Itens } \quad \text { Loja (1) Loja (2) }
$$

38 Possui maior variedade.

39 Horário de funcionamento

40 Facilidade de acesso.

41 Estacionamento.

42 Perecíveis (variedade e qualidade)......

43 Semi-prontos (variedade e qualidade).

44 Entrega ao domicílio.

45 Caixa automatizado..

46 Atendimento

47. Nos últimos 5 anos, alguma grande rede de hiper/supermercado se instalou perto de sua loja?

Não Sim Qual (nome):

Caso positivo na questão 47, houve redução nas vendas (faturamento)?

Não Sim, quanto em média? até $20 \%$; até $40 \%$; até $60 \%$, mais de $60 \%$;

Qual foi a reação da sua loja frente ao novo concorrente?

48. Em que ano começou a participar da associação? 


\section{PARTE II - ASSOCIADOS / COOPERADOS OU CENTRAL DE COMPRAS}

Indique com $(\sqrt{ })$ quais os itens abaixo a associação/cooperativa, ou a central de compra fornece aos associados, e em caso afirmativo, o grau de satisfação. (1 - muito satisfeito, 2 - satisfeito, 3 - pouco satisfeito, 4 - insatisfeito, 5 - muito insatisfeito)

49

50

51

52

53

54

55

56

57

58

59

60

61

62

63

64

65

66

67

68
Mix de Produtos.

Sistema de Pedido.

Quantidades mínimas.

Paletização.

Negociação em Conjunto

Consultoria.

Layout da Loja.

Propaganda em Jornal.

Propaganda em TV.....

Propaganda em Rádio.

Propaganda em Tabloides.

Treinamento de Gerente.

Treinamento de Funcionários........

Cartão de Fidelidade.

Acesso a compra/serviços de equipamentos.

Padrões de operação (manuais)....

Produtos com Marca Própria.

Outros: (Quais ?)

\section{Grau de satisfação}

\begin{tabular}{|l|l|l|l|l|}
\hline 1 & 2 & 3 & 4 & 5 \\
\hline 1 & 2 & 3 & 4 & 5 \\
\hline 1 & 2 & 3 & 4 & 5 \\
\hline 1 & 2 & 3 & 4 & 5 \\
\hline 1 & 2 & 3 & 4 & 5 \\
1 & 2 & 3 & 4 & 5 \\
\hline 1 & 2 & 3 & 4 & 5 \\
\hline 1 & 2 & 3 & 4 & 5 \\
\hline 1 & 2 & 3 & 4 & 5 \\
\hline 1 & 2 & 3 & 4 & 5 \\
\hline 1 & 2 & 3 & 4 & 5 \\
\hline 1 & 2 & 3 & 4 & 5 \\
\hline 1 & 2 & 3 & 4 & 5 \\
\hline 1 & 2 & 3 & 4 & 5 \\
\hline 1 & 2 & 3 & 4 & 5 \\
\hline 1 & 2 & 3 & 4 & 5 \\
\hline 1 & 2 & 3 & 4 & 5 \\
\hline \multicolumn{5}{|r|}{} \\
\hline 1 & 2 & 3 & 4 & 5 \\
\hline 1 & 2 & 3 & 4 & 5 \\
\hline 1 & 2 & 3 & 4 & 5 \\
\hline
\end{tabular}

\begin{tabular}{|c|l|c|c|c|c|c|}
\hline 69 & $\begin{array}{l}\text { Qual a participação do total dos itens da loja } \\
\text { que é fornecido pela associação ? }\end{array}$ & $0-20 \%$ & $21-40 \%$ & $41-60 \%$ & $61-80 \%$ & $\begin{array}{c}\text { mais de } \\
81 \%\end{array}$ \\
\hline 70 & $\begin{array}{l}\text { Qual a diminuição dos custos de aquisição } \\
\text { destes produtos (em média) ? }\end{array}$ & $0 \%$ & $0,1-2 \%$ & $2,1-4 \%$ & $4,1-6 \%$ & $\begin{array}{c}\text { mais de } \\
6 \%\end{array}$ \\
\hline 71 & Qual foi o aumento médio no faturamento ? & $0 \%$ & $0,1-2 \%$ & $2,1-5 \%$ & $5,1-10 \%$ & $\begin{array}{c}\text { mais de } \\
10 \%\end{array}$ \\
\hline
\end{tabular}


Após início das atividades na associação/cooperativa ou central de compras:

72. houve redução no número de funcionários?

$$
\text { Não Sim }
$$

Quanto, em média? até 2\%; até 6\%; até 10\%; mais de $10 \%$

73. houve redução nos estoques (em volume)?

Não Sim

Quanto, em média? até 5\%; até $10 \%$; até $15 \%$; mais de $15 \%$

74. houve redução nos preços dos produtos vendidos?

Não Sim

Quanto, em média? até 2\%; até 6\%; até 10\%; mais de $10 \%$

75. houve melhora na qualidade dos produtos?

Não Sim Não sei

76. o cliente percebeu melhora do atendimento?

Não Sim Não sei

77. houve redução nas faltas (produtos ausentes nas lojas)?

Não Sim Não sei

78. Assinale quais foram as principais razões que levaram ao supermercado a associarse:

Altos custo de compra das mercadorias

Operação da loja

Incremento da profissionalização da concorrência

Dificuldade em se adquiri mercadorias

Distanciamento das indústrias

Redução das vendas

Aumento da competição

Custos de propaganda

Problema com a qualidade dos produtos

Falta de treinamento dos funcionários

Acesso ànovas tecnologias

Outros: 
APÊNDICE 3 - Resultados do questionário.

Questão 2. Qual a área de venda aproximada da loja?

\begin{tabular}{lccc}
\hline \multicolumn{1}{c}{ Área de vendas $\left(\mathrm{m}^{2}\right)$} & Rede Econômica & Rede Economize & Total \\
\hline até 250 & $41,7 \%$ & $12,5 \%$ & $30,0 \%$ \\
$251-1000$ & $50,0 \%$ & $87,5 \%$ & $65,0 \%$ \\
$1001-2500$ & & & \\
$2501-5000$ & & & \\
mais de 5001 & & & $5,0 \%$ \\
Não respondeu & $8,3 \%$ & & \\
\hline
\end{tabular}

Questão 3. Qual o número aproximado de produtos ativos vendidos?

\begin{tabular}{lccc}
\hline \multicolumn{1}{c}{ Número de itens vendidos } & Rede Econômica & Rede Economize & Total \\
\hline até 300 & & & \\
$301-4500$ & $66,7 \%$ & $37,5 \%$ & $55,0 \%$ \\
$4501-7000$ & $16,7 \%$ & $62,5 \%$ & $35,0 \%$ \\
$7001-9000$ & $16,7 \%$ & & $10,0 \%$ \\
mais de 9001 & & & \\
Não respondeu & & & \\
\hline
\end{tabular}

Questão 4. Qual o número de caixas?

\begin{tabular}{lccc}
\hline Número de caixas por lojas & Rede Econômica & Rede Economize & Total \\
\hline até 4 & $91,7 \%$ & $75,0 \%$ & $85,0 \%$ \\
$5-9$ & $8,3 \%$ & $25,0 \%$ & $15,0 \%$ \\
$10-19$ & & & \\
$20-29$ & & & \\
mais de 30 & & & \\
Não respondeu & & & \\
\hline
\end{tabular}

Questão 5. Qual é o faturamento bruto mensal médio de vendas?

\begin{tabular}{lccc}
\hline Faturamento bruto mensal (mil reais) & Rede Econômica & Rede Economize & Total \\
\hline até 50 & & & \\
$51-100$ & & $12,5 \%$ & $5,0 \%$ \\
$101-300$ & $91,7 \%$ & $62,5 \%$ & $80,0 \%$ \\
$301-500$ & $8,3 \%$ & $12,5 \%$ & $10,0 \%$ \\
$501-700$ & & & \\
mais de 700 & & $12,5 \%$ & $5,0 \%$ \\
Não respondeu & & & \\
\hline
\end{tabular}


Questões 6 e 7. Gastos diretos do supermercado nos seguintes meios de comunicação.

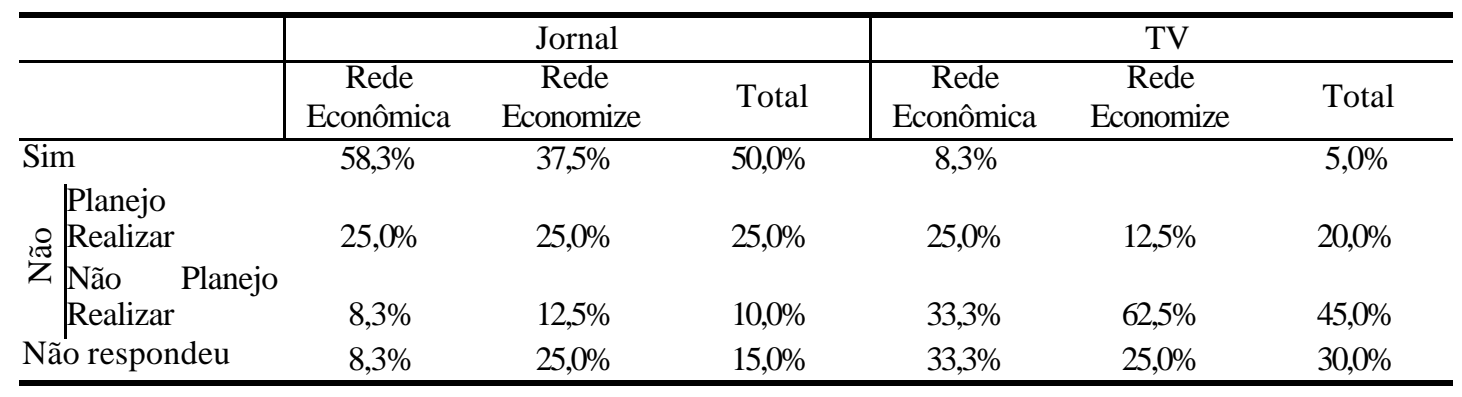

Questões 8 a 10. Gastos diretos do supermercado nos seguintes meios de comunicação.

\begin{tabular}{|c|c|c|c|c|c|c|c|c|c|}
\hline & \multicolumn{3}{|c|}{ Rádio } & \multicolumn{3}{|c|}{ Outdoor } & \multicolumn{3}{|c|}{ Panfletagem } \\
\hline & $\begin{array}{c}\text { Rede } \\
\text { Econônmica }\end{array}$ & $\begin{array}{c}\text { Rede } \\
\text { Economize }\end{array}$ & Total & $\begin{array}{c}\text { Rede } \\
\text { Econômica }\end{array}$ & $\begin{array}{c}\text { Rede } \\
\text { Economize }\end{array}$ & Total & $\begin{array}{c}\text { Rede } \\
\text { Econômica }\end{array}$ & $\begin{array}{c}\text { Rede } \\
\text { Economize }\end{array}$ & Total \\
\hline Sim & $83,3 \%$ & $75,0 \%$ & $80,0 \%$ & $8,3 \%$ & $25,0 \%$ & $15,0 \%$ & $91,7 \%$ & $87,5 \%$ & $90,0 \%$ \\
\hline$\approx$ Realizar & $8,3 \%$ & & $5,0 \%$ & $25,0 \%$ & $12,5 \%$ & $20,0 \%$ & & & \\
\hline $\begin{array}{l}\text { Zão Planejo } \\
\text { Realizar }\end{array}$ & $8,3 \%$ & $25,0 \%$ & $15,0 \%$ & $41,7 \%$ & $37,5 \%$ & $40,0 \%$ & $8,3 \%$ & $12,5 \%$ & $10,0 \%$ \\
\hline Não respondeu & & & & $25,0 \%$ & $25,0 \%$ & $25,0 \%$ & & & \\
\hline
\end{tabular}

Questões 11 a 13. A loja possui seguintes serviços ou produtos? Caso não haja, planeja faze-lo?

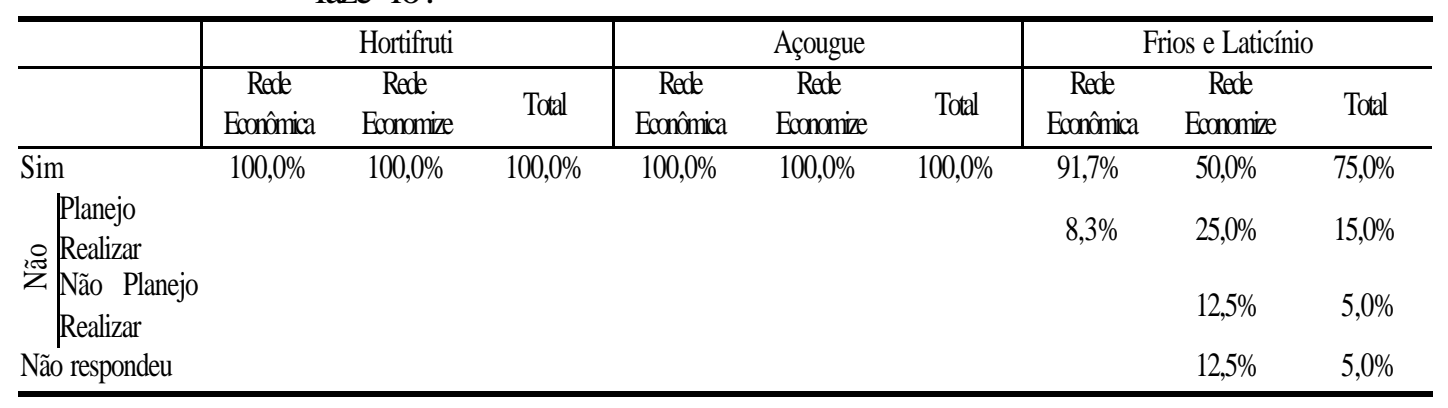

Questões 14 a 16. A loja possui seguintes serviços ou produtos? Caso não haja, planeja faze-lo?

\begin{tabular}{|c|c|c|c|c|c|c|c|c|c|}
\hline & \multicolumn{3}{|c|}{ Padaria } & \multicolumn{3}{|c|}{ Promotor de Vendas } & \multicolumn{3}{|c|}{ Rotisserie } \\
\hline & $\begin{array}{c}\text { Rede } \\
\text { Econônimica }\end{array}$ & $\begin{array}{c}\text { Rede } \\
\text { Economize }\end{array}$ & Total & $\begin{array}{c}\text { Rede } \\
\text { Econônimica }\end{array}$ & $\begin{array}{c}\text { Rede } \\
\text { Economize }\end{array}$ & Total & $\begin{array}{l}\text { Rede } \\
\text { Econônimica }\end{array}$ & $\begin{array}{c}\text { Rede } \\
\text { Economize }\end{array}$ & Total \\
\hline Sim & $50,0 \%$ & $50,0 \%$ & $50,0 \%$ & $41,7 \%$ & $25,0 \%$ & $35,0 \%$ & $41,7 \%$ & $12,5 \%$ & $30,0 \%$ \\
\hline $\mid \begin{array}{l}\text { Planejo } \\
\text { Realizar }\end{array}$ & $41,7 \%$ & $25,0 \%$ & $35,0 \%$ & $16,7 \%$ & $37,5 \%$ & $25,0 \%$ & $25,0 \%$ & $25,0 \%$ & $25,0 \%$ \\
\hline $\begin{array}{l}\text { Zão Planejo } \\
\text { Realizar }\end{array}$ & & $12,5 \%$ & $5,0 \%$ & $41,7 \%$ & $12,5 \%$ & $30,0 \%$ & $25,0 \%$ & $37,5 \%$ & $30,0 \%$ \\
\hline Não respondeu & $8,3 \%$ & $12,5 \%$ & $10,0 \%$ & & $25,0 \%$ & $10,0 \%$ & $8,3 \%$ & $25,0 \%$ & $15,0 \%$ \\
\hline
\end{tabular}


Questões 17 a 19. A loja possui seguintes serviços ou produtos? Caso não haja, planeja faze-lo?

\begin{tabular}{|c|c|c|c|c|c|c|c|c|c|}
\hline & \multicolumn{3}{|c|}{ Marca Própria } & \multicolumn{3}{|c|}{ Programa de Fidelidade } & \multicolumn{3}{|c|}{$\begin{array}{c}\text { Sistema de Integração } \\
\text { Frente e Retaguarda }\end{array}$} \\
\hline & $\begin{array}{c}\text { Rede } \\
\text { Econônmica }\end{array}$ & $\begin{array}{c}\text { Rede } \\
\text { Economize }\end{array}$ & Total & $\begin{array}{c}\text { Rede } \\
\text { Econômica }\end{array}$ & $\begin{array}{c}\text { Rede } \\
\text { Economize }\end{array}$ & Total & $\begin{array}{c}\text { Rede } \\
\text { Econônica }\end{array}$ & $\begin{array}{c}\text { Rede } \\
\text { Economize }\end{array}$ & Total \\
\hline Sim & $100,0 \%$ & $50,0 \%$ & $80,0 \%$ & $100,0 \%$ & $87,5 \%$ & $95,0 \%$ & $83,3 \%$ & $62,5 \%$ & $75,0 \%$ \\
\hline \begin{tabular}{l|l} 
Planejo \\
Realizar
\end{tabular} & & $12,5 \%$ & $5,0 \%$ & & & & & $12,5 \%$ & $5,0 \%$ \\
\hline $\begin{array}{l}\text { Z } \\
\text { Não Planejo } \\
\text { Realizar }\end{array}$ & & $25,0 \%$ & $10,0 \%$ & & $12,5 \%$ & $5,0 \%$ & $8,3 \%$ & $12,5 \%$ & $10,0 \%$ \\
\hline Não respondeu & & $12,5 \%$ & $5,0 \%$ & & & & $8,3 \%$ & $12,5 \%$ & $10,0 \%$ \\
\hline
\end{tabular}

Questões 20 a 22. A loja possui seguintes serviços ou produtos? Caso não haja, planeja faze-lo?

\begin{tabular}{l|ccc|ccc|ccc}
\hline & \multicolumn{3}{|c|}{ Caixa Automatizada } & \multicolumn{3}{c|}{ Balança Eletrônica } & \multicolumn{3}{c}{ Entrega a Domicílio } \\
\hline & $\begin{array}{c}\text { Rede } \\
\text { Econômica }\end{array}$ & $\begin{array}{c}\text { Rede } \\
\text { Economize }\end{array}$ & Total & $\begin{array}{c}\text { Rede } \\
\text { Econômica }\end{array}$ & $\begin{array}{c}\text { Rede } \\
\text { Economize }\end{array}$ & Total & $\begin{array}{c}\text { Rede } \\
\text { Econômica }\end{array}$ & $\begin{array}{c}\text { Rede } \\
\text { Economiz }\end{array}$ & Total \\
\hline Sim & $91,7 \%$ & $75,0 \%$ & $85,0 \%$ & $100,0 \%$ & $87,5 \%$ & $95,0 \%$ & $91,7 \%$ & $75,0 \%$ & $85,0 \%$ \\
$\begin{array}{l}\text { Planejo } \\
\text { Realizar }\end{array}$ & $12,5 \%$ & $5,0 \%$ & & & & $8,3 \%$ & $12,5 \%$ & $10,0 \%$ \\
Não Planejo & $8,3 \%$ & & $5,0 \%$ & & & & & & \\
Realizar & & $12,5 \%$ & $5,0 \%$ & & $12,5 \%$ & $5,0 \%$ & & $12,5 \%$ & $5,0 \%$ \\
\hline
\end{tabular}

Questões 23 a 25. A loja possui seguintes serviços ou produtos? Caso não haja, planeja faze-lo?

\begin{tabular}{|c|c|c|c|c|c|c|c|c|c|}
\hline & \multicolumn{3}{|c|}{ Empacotadores } & \multicolumn{3}{|c|}{ Vagas para Carros } & \multicolumn{3}{|c|}{ Gerenciamento de Categorias } \\
\hline & $\begin{array}{c}\text { Rede } \\
\text { Econômica }\end{array}$ & $\begin{array}{c}\text { Rede } \\
\text { Economize }\end{array}$ & Total & $\begin{array}{c}\text { Rede } \\
\text { Econônica }\end{array}$ & $\begin{array}{c}\text { Rede } \\
\text { Economize }\end{array}$ & Total & $\begin{array}{c}\text { Rede } \\
\text { Econômica }\end{array}$ & $\begin{array}{c}\text { Rede } \\
\text { Economize }\end{array}$ & Total \\
\hline Sim & $91,7 \%$ & $75,0 \%$ & $85,0 \%$ & $75,0 \%$ & $100,0 \%$ & $85,0 \%$ & $33,3 \%$ & $62,5 \%$ & $45,0 \%$ \\
\hline \begin{tabular}{l|l} 
Planejo \\
Realizar
\end{tabular} & & & & $8,3 \%$ & & $5,0 \%$ & $41,7 \%$ & $25,0 \%$ & $35,0 \%$ \\
\hline$\stackrel{2 \pi}{Z} \begin{array}{l}\begin{array}{l}\text { ão } \\
\text { Planejo } \\
\text { Realizar }\end{array}\end{array}$ & & $12,5 \%$ & $5,0 \%$ & $16,7 \%$ & & $10,0 \%$ & $16,7 \%$ & $12,5 \%$ & $15,0 \%$ \\
\hline Não respondeu & $8,3 \%$ & $12,5 \%$ & $10,0 \%$ & & & & $8,3 \%$ & & $5,0 \%$ \\
\hline
\end{tabular}


Questões 26 e 27. Número de horas de treinamento para um típico recém-contratado, por atividade.

\begin{tabular}{l|ccc|ccc}
\hline & \multicolumn{3}{|c|}{ Caixa } & \multicolumn{3}{c}{ Repositor de Produtos } \\
\hline & Rede Econômica & Rede Economize & Total & Rede Econômica Rede Economize & Total \\
\hline não há treinamento & $25,0 \%$ & $62,5 \%$ & $40,0 \%$ & $41,7 \%$ & $50,0 \%$ & $45,0 \%$ \\
até 8 horas & $8,3 \%$ & $12,5 \%$ & $10,0 \%$ & $25,0 \%$ & $12,5 \%$ & $20,0 \%$ \\
de 9 à24 horas & $8,3 \%$ & $12,5 \%$ & $10,0 \%$ & $8,3 \%$ & $37,5 \%$ & $20,0 \%$ \\
mais de 25 horas & $50,0 \%$ & $12,5 \%$ & $35,0 \%$ & $16,7 \%$ & $10,0 \%$ \\
Não respondeu & $8,3 \%$ & & $5,0 \%$ & $8,3 \%$ & $5,0 \%$ \\
\hline
\end{tabular}

Questões 28 e 29. Número de horas de treinamento para um típico recém-contratado, por atividade.

\begin{tabular}{lccc|ccc}
\hline \multicolumn{3}{c|}{ Repositor de FLV } & \multicolumn{3}{c}{ Padeiro } \\
\hline & Rede Econômica & Rede Economize & Total & Rede Econômica & Rede Economize & Total \\
\hline não há treinamento & $41,7 \%$ & $62,5 \%$ & $50,0 \%$ & $33,3 \%$ & $62,5 \%$ & $45,0 \%$ \\
até 8 horas & $8,3 \%$ & $25,0 \%$ & $15,0 \%$ & & & \\
de 9 à 24 horas & $8,3 \%$ & $12,5 \%$ & $10,0 \%$ & $8,3 \%$ & & $5,0 \%$ \\
mais de 25 horas & $8,3 \%$ & & $5,0 \%$ & $16,7 \%$ & $25,0 \%$ & $20,0 \%$ \\
Não respondeu & $33,3 \%$ & & $20,0 \%$ & $41,7 \%$ & $12,5 \%$ & $30,0 \%$ \\
\hline
\end{tabular}

Questões 30 e 31. Número de horas de treinamento para um típico recém-contratado, por atividade.

\begin{tabular}{lccc|ccr}
\hline & \multicolumn{3}{c|}{$\begin{array}{c}\text { Açougueiro } \\
\end{array}$} & \multicolumn{3}{c}{ Peixeiro } \\
& Rede Econômica & Rede Economize & Total & Rede Econômica & Rede Economize & Total \\
\hline não há treinamento & $33,3 \%$ & $50,0 \%$ & $40,0 \%$ & $41,7 \%$ & $50,0 \%$ & $45,0 \%$ \\
até 8 horas & & & & & & \\
de 9 à 24 horas & $16,7 \%$ & $12,5 \%$ & $15,0 \%$ & & & \\
mais de 25 horas & $33,3 \%$ & $25,0 \%$ & $30,0 \%$ & $8,3 \%$ & $12,5 \%$ & $10,0 \%$ \\
Não respondeu & $16,7 \%$ & $12,5 \%$ & $15,0 \%$ & $50,0 \%$ & $37,5 \%$ & $45,0 \%$ \\
\hline
\end{tabular}

Questões 32 e 33. Número de horas de treinamento para um típico recém-contratado, por atividade.

\begin{tabular}{lccc|ccc}
\hline & \multicolumn{2}{c|}{ Frios } & \multicolumn{3}{c}{ Chefe de Seção } \\
\hline & Rede Econômica & Rede Economize & Total & Rede Econômica & Rede Economize & Total \\
\hline não há treinamento & $33,3 \%$ & $50,0 \%$ & $40,0 \%$ & $33,3 \%$ & $50,0 \%$ & $40,0 \%$ \\
até 8 horas & $16,7 \%$ & & $10,0 \%$ & $33,3 \%$ & & $20,0 \%$ \\
de 9 à 24 horas & & $25,0 \%$ & $10,0 \%$ & & & \\
mais de 25 horas & $25,0 \%$ & $25,0 \%$ & $25,0 \%$ & $33,3 \%$ & $12,5 \%$ & $25,0 \%$ \\
Não respondeu & $25,0 \%$ & & $15,0 \%$ & & $37,5 \%$ & $15,0 \%$ \\
\hline
\end{tabular}


Questões 34 e 36. Nome dos dois supermercados que são os principais concorrentes da loja pesquisada.

\begin{tabular}{|c|c|}
\hline \multicolumn{2}{|c|}{ Principais concorrentes } \\
\hline Loja 1 & Loja 2 \\
\hline Beira Rio (*) & $3 B$ \\
\hline Coopideal & Big \\
\hline Enxuto $(*)$ & Champion \\
\hline Hortifruti & Cobra \\
\hline LDA & Corso \\
\hline Mercado Popular & Delta \\
\hline O Barateiro & Enxuto \\
\hline Paulistão & Ferrari \\
\hline Sempre Vale $(*)$ & Loja Rede Econômica \\
\hline Supermercado Barbosa & Mercado dos Pompos \\
\hline Supermercado Caetano & Sempre Va le (*) \\
\hline Supermercado Compre Bem & Supermercado Calsa \\
\hline Supermercado Costa & Supermercado do Juca \\
\hline Supermercado Guari & Supermercado Nespin \\
\hline Supermercado Sempre Vale & Supermercados Piua \\
\hline Supr. Ouro Verde & \\
\hline
\end{tabular}

(*) Supermercados citados duas vezes.

Questões 35 e 37. Distância dos dois supermercados que são os principais concorrentes de loja dos associados.

\begin{tabular}{|c|c|c|c|c|c|c|c|c|c|}
\hline \multirow{2}{*}{$\begin{array}{l}\text { Distância dos dois } \\
\text { principais concorrentes } \\
\text { das lojas associadas }\end{array}$} & \multicolumn{3}{|c|}{ Loja 1} & \multicolumn{3}{|c|}{ Loja 2} & \multicolumn{3}{|c|}{ Total (lojas 1+2) } \\
\hline & $\begin{array}{c}\text { Rede } \\
\text { Econômica }\end{array}$ & $\begin{array}{c}\text { Rede } \\
\text { Economize }\end{array}$ & Total & $\begin{array}{c}\text { Rede } \\
\text { Econômica }\end{array}$ & $\begin{array}{c}\text { Rede } \\
\text { Economize }\end{array}$ & Total & $\begin{array}{c}\text { Rede } \\
\text { Econômica }\end{array}$ & $\begin{array}{c}\text { Rede } \\
\text { Economize }\end{array}$ & Total \\
\hline até $500 \mathrm{~m}$ & $33,3 \%$ & $50,0 \%$ & $40,0 \%$ & $25,0 \%$ & $50,0 \%$ & $35,0 \%$ & $29,2 \%$ & $50,0 \%$ & $37,5 \%$ \\
\hline até $2 \mathrm{~km}$ & $33,3 \%$ & $25,0 \%$ & $30,0 \%$ & $16,7 \%$ & $25,0 \%$ & $20,0 \%$ & $25,0 \%$ & $25,0 \%$ & $25,0 \%$ \\
\hline até $5 \mathrm{~km}$ & $8,3 \%$ & $12,5 \%$ & $10,0 \%$ & $25,0 \%$ & & $15,0 \%$ & $16,7 \%$ & $6,3 \%$ & $12,5 \%$ \\
\hline mais $5 \mathrm{~km}$ & & $12,5 \%$ & $5,0 \%$ & $8,3 \%$ & & $5,0 \%$ & $4,2 \%$ & $6,3 \%$ & $5,0 \%$ \\
\hline Não respondeu & $25,0 \%$ & & $15,0 \%$ & $25,0 \%$ & $25,0 \%$ & $25,0 \%$ & $25,0 \%$ & $12,5 \%$ & $20,0 \%$ \\
\hline
\end{tabular}

Questões 38 a 46. Itens em que na loja do concorrente citado são melhores do que do associado.

\begin{tabular}{lccc}
\hline Itens & Rede Econômica & Rede Economize & Total \\
\hline Horário de funcionamento & $91,7 \%$ & $75,0 \%$ & $85,0 \%$ \\
Estacionamento & $66,7 \%$ & $62,5 \%$ & $65,0 \%$ \\
Variedade & $66,7 \%$ & $62,5 \%$ & $65,0 \%$ \\
Perecíveis (variedade e qualidade) & $66,7 \%$ & $37,5 \%$ & $55,0 \%$ \\
Semi-prontos (variedade e qualidade) & $75,0 \%$ & $25,0 \%$ & $55,0 \%$ \\
Facilidade de acesso & $33,3 \%$ & $37,5 \%$ & $35,0 \%$ \\
Caixa automatizados & $25,0 \%$ & $25,0 \%$ & $25,0 \%$ \\
Entrega ao domicílio & $16,7 \%$ & $12,5 \%$ & $15,0 \%$ \\
Atendimento & $8,3 \%$ & $12,5 \%$ & $10,0 \%$ \\
\hline
\end{tabular}


Questão 47. Nos últimos cinco anos alguma grande rede de hiper/supermercado se instalou perto de sua loja?

\begin{tabular}{lccc}
\hline & Rede Econômica & Rede Economize & Total \\
\hline $\begin{array}{l}\text { Instalação de lojas de grandes redes } \\
\text { perto da loja do associado }\end{array}$ & $50,0 \%$ & $62,5 \%$ & $55,0 \%$ \\
\hline
\end{tabular}

Qual o nome da rede de aberta?

\begin{tabular}{lcl}
\hline & Nome dos grandes hiper/supermercados que & foram citados \\
\hline Beira Rio & Hipermercados Big $(*)$ & Supermercado Corso \\
Carrefour & Hipermercados Enxuto $(* *)$ & Supermercado Paulistão \\
Champion & Sé Supermercados & Supermercado Sempre Vale $(* *)$ \\
\hline
\end{tabular}

$\left.{ }^{*}\right)$ Citado quatro vezes $(* *)$ citado duas vezes

Houve queda no faturamento? Caso positivo, de quanto foi (em porcentagem)?

\begin{tabular}{lccc}
\hline Redução no faturamento & Rede Econômica & Rede Economize & Total \\
\hline Não houve queda de faturamento & $33,3 \%$ & $25,0 \%$ & $30,0 \%$ \\
até $20 \%$ & $16,7 \%$ & $37,5 \%$ & $25,0 \%$ \\
até $40 \%$ & & & \\
até $60 \%$ & & & \\
mais de 60\% & & $37,5 \%$ & $45,0 \%$ \\
Não respondeu & $50,0 \%$ & & \\
\hline
\end{tabular}

Questão 48. Em que ano começou a participar da associação?

\begin{tabular}{lccc}
\hline Início de participação na associação & Rede Econômica & Rede Economize & Total \\
\hline 1998 & $50,0 \%$ & & $30,0 \%$ \\
1999 & $33,3 \%$ & $37,5 \%$ & $35,0 \%$ \\
2000 & $16,7 \%$ & & $10,0 \%$ \\
2001 & & $50,0 \%$ & $20,0 \%$ \\
Não respondeu & & $12,5 \%$ & $5,0 \%$ \\
\hline
\end{tabular}

Questões 49 a 65. Itens em que a associação fornece e o grau de satisfação (1-muito satisfeito, 2 - satisfeito, 3-pouco satisfeit o, 4-insatisfeito, 5- muito insatisfeito). ${ }^{44}$

\begin{tabular}{llccccc}
\hline \multirow{2}{*}{ Itens } & \multicolumn{1}{c}{ Rede } & \multicolumn{5}{c}{ Grau de satisfação } \\
\cline { 3 - 7 } & & 1 & 2 & 3 & 4 & 5 \\
\hline \multirow{2}{*}{ Mix } & Rede Econômica & $25,0 \%$ & $50,0 \%$ & $8,3 \%$ & & $16,7 \%$ \\
& Rede Economize & $12,5 \%$ & $12,5 \%$ & $37,5 \%$ & $12,5 \%$ & $25,0 \%$ \\
& Total & $20,0 \%$ & $35,0 \%$ & $20,0 \%$ & $5,0 \%$ & $20,0 \%$
\end{tabular}

44 Ao não responder, entende-se que a associação não fornece o respectivo item, porém alguns pesquisados assinalaram o Grau de Satisfação número 5 quando o serviço não é prestado, como, por exemplo, Paletização, Propaganda em TV e Acesso à Equipamentos. 
Questões 49 a 65 . Itens em que a associação fornece e o grau de satisfação (1-muito satisfeito, 2 - satisfeito, 3-pouco satisfeito, 4-insatisfeito, 5- muito insatisfeito). ${ }^{45}$

\begin{tabular}{|c|c|c|c|c|c|c|c|}
\hline \multirow{2}{*}{ Itens } & \multirow[b]{2}{*}{ Rede } & \multicolumn{5}{|c|}{ Grau de satisfação } & \multirow[b]{2}{*}{ Não respondeu } \\
\hline & & 1 & 2 & 3 & 4 & 5 & \\
\hline \multirow{3}{*}{$\begin{array}{l}\text { Sistema de } \\
\text { Pedido }\end{array}$} & Rede Econômica & $41,7 \%$ & $41,7 \%$ & & & & $16,7 \%$ \\
\hline & Rede Economize & $12,5 \%$ & $50,0 \%$ & & $12,5 \%$ & $12,5 \%$ & $12,5 \%$ \\
\hline & Total & $30,0 \%$ & $45,0 \%$ & & $5,0 \%$ & $5,0 \%$ & $15,0 \%$ \\
\hline \multirow{3}{*}{$\begin{array}{l}\text { Quantidade } \\
\text { Mínima }\end{array}$} & Rede Econômica & $50,0 \%$ & $41,7 \%$ & & & & $8,3 \%$ \\
\hline & Rede Economize & & $25,0 \%$ & & $12,5 \%$ & & $62,5 \%$ \\
\hline & Total & $30,0 \%$ & $35,0 \%$ & & $5,0 \%$ & & $30,0 \%$ \\
\hline \multirow{3}{*}{ Paletização } & Rede Econômica & $8,3 \%$ & $16,7 \%$ & & $8,3 \%$ & $8,3 \%$ & $58,3 \%$ \\
\hline & Rede Economize & & & & & $25,0 \%$ & $75,0 \%$ \\
\hline & Total & $5,0 \%$ & $10,0 \%$ & & $5,0 \%$ & $15,0 \%$ & $65,0 \%$ \\
\hline \multirow{3}{*}{$\begin{array}{l}\text { Negociação } \\
\text { Conjunta }\end{array}$} & Rede Econômica & $50,0 \%$ & $41,7 \%$ & $8,3 \%$ & & & \\
\hline & Rede Economize & $25,0 \%$ & $12,5 \%$ & $25,0 \%$ & $25,0 \%$ & & $12,5 \%$ \\
\hline & Total & $40,0 \%$ & $30,0 \%$ & $15,0 \%$ & $10,0 \%$ & & $5,0 \%$ \\
\hline \multirow{3}{*}{ Consultoria } & Rede Econômica & $8,3 \%$ & $8,3 \%$ & $8,3 \%$ & & $8,3 \%$ & $66,7 \%$ \\
\hline & Rede Economize & & & $12,5 \%$ & $12,5 \%$ & $12,5 \%$ & $62,5 \%$ \\
\hline & Total & $5,0 \%$ & $5,0 \%$ & $10,0 \%$ & $5,0 \%$ & $10,0 \%$ & $65,0 \%$ \\
\hline \multirow{3}{*}{$\begin{array}{l}\text { Layout da } \\
\text { Loja }\end{array}$} & Rede Econômica & $8,3 \%$ & $25,0 \%$ & & $8,3 \%$ & $8,3 \%$ & $50,0 \%$ \\
\hline & Rede Economize & & $12,5 \%$ & $12,5 \%$ & $12,5 \%$ & & $62,5 \%$ \\
\hline & Total & $5,0 \%$ & $20,0 \%$ & $5,0 \%$ & $10,0 \%$ & $5,0 \%$ & $55,0 \%$ \\
\hline \multirow{3}{*}{$\begin{array}{l}\text { Propaganda } \\
\text { em Jornal }\end{array}$} & Rede Econômica & $25,0 \%$ & $50,0 \%$ & & $8,3 \%$ & & $16,7 \%$ \\
\hline & Rede Economize & $12,5 \%$ & $12,5 \%$ & & $25,0 \%$ & $12,5 \%$ & $37,5 \%$ \\
\hline & Total & $20,0 \%$ & $35,0 \%$ & & $15,0 \%$ & $5,0 \%$ & $25,0 \%$ \\
\hline \multirow{3}{*}{$\begin{array}{l}\text { Propaganda } \\
\text { na TV }\end{array}$} & Rede Econômica & & & & & $25,0 \%$ & $75,0 \%$ \\
\hline & Rede Economize & & & & & $37,5 \%$ & $62,5 \%$ \\
\hline & Total & & & & & $30,0 \%$ & $70,0 \%$ \\
\hline \multirow{3}{*}{$\begin{array}{l}\text { Propaganda } \\
\text { no Rádio }\end{array}$} & Rede Econômica & $33,3 \%$ & $58,3 \%$ & $8,3 \%$ & & & \\
\hline & Rede Economize & & & & $12,5 \%$ & $12,5 \%$ & $75,0 \%$ \\
\hline & Total & $20,0 \%$ & $35,0 \%$ & $5,0 \%$ & $5,0 \%$ & $5,0 \%$ & $30,0 \%$ \\
\hline
\end{tabular}

45 Ao não responder, entende-se que a associação não fornece o respectivo item, porém alguns pesquisados assinalaram o Grau de Satisfação número 5 quando o serviço não é prestado, como, por exemplo, Paletização, Propaganda em TV e Acesso àEquipamentos. 
Questões 49 a 65. Itens em que a associação fornece e o grau de satisfação (1-muito satisfeito, 2 - satisfeito, 3-pouco satisfeito, 4-insatisfeito, 5- muito insatisfeito). ${ }^{46}$

\begin{tabular}{|c|c|c|c|c|c|c|c|}
\hline \multirow{2}{*}{ Itens } & \multirow{2}{*}{ Rede } & \multicolumn{5}{|c|}{ Grau de satisfação } & \multirow[b]{2}{*}{ Não respondeu } \\
\hline & & 1 & 2 & 3 & 4 & 5 & \\
\hline \multirow{3}{*}{$\begin{array}{l}\text { Propaganda } \\
\text { no Tablóide }\end{array}$} & Rede Econômica & $58,3 \%$ & $16,7 \%$ & & $8,3 \%$ & & $16,7 \%$ \\
\hline & Rede Economize & $25,0 \%$ & $50,0 \%$ & & & $12,5 \%$ & $12,5 \%$ \\
\hline & Total & $45,0 \%$ & $30,0 \%$ & & $5,0 \%$ & $5,0 \%$ & $15,0 \%$ \\
\hline \multirow{3}{*}{$\begin{array}{l}\text { Treinamento } \\
\text { de Gerentes }\end{array}$} & Rede Econômica & & $8,3 \%$ & & $8,3 \%$ & $8,3 \%$ & $75,0 \%$ \\
\hline & Rede Economize & & & & $12,5 \%$ & $12,5 \%$ & $75,0 \%$ \\
\hline & Total & & $5,0 \%$ & & $10,0 \%$ & $10,0 \%$ & $75,0 \%$ \\
\hline \multirow{3}{*}{$\begin{array}{l}\text { Treinamento } \\
\text { de } \\
\text { Funcionário }\end{array}$} & Rede Econômica & & $8,3 \%$ & & $8,3 \%$ & $16,7 \%$ & $66,7 \%$ \\
\hline & Rede Economize & & & & $12,5 \%$ & $12,5 \%$ & $75,0 \%$ \\
\hline & Total & & $5,0 \%$ & & $10,0 \%$ & $15,0 \%$ & $70,0 \%$ \\
\hline \multirow{3}{*}{$\begin{array}{l}\text { Cartão de } \\
\text { Fidelidade }\end{array}$} & Rede Econômica & $50,0 \%$ & $33,3 \%$ & $8,3 \%$ & & & $8,3 \%$ \\
\hline & Rede Economize & $37,5 \%$ & $37,5 \%$ & & $12,5 \%$ & & $12,5 \%$ \\
\hline & Total & $45,0 \%$ & $35,0 \%$ & $5,0 \%$ & $5,0 \%$ & & $10,0 \%$ \\
\hline \multirow{3}{*}{$\begin{array}{l}\text { Acesso à } \\
\text { Equipamentos }\end{array}$} & Rede Econômica & & $16,7 \%$ & & & $16,7 \%$ & $66,7 \%$ \\
\hline & Rede Economize & & & & $12,5 \%$ & $12,5 \%$ & $75,0 \%$ \\
\hline & Total & & $10,0 \%$ & & $5,0 \%$ & $15,0 \%$ & $70,0 \%$ \\
\hline \multirow{3}{*}{$\begin{array}{l}\text { Padrões de } \\
\text { Operação }\end{array}$} & Rede Econômica & & $16,7 \%$ & $8,3 \%$ & & $8,3 \%$ & $66,7 \%$ \\
\hline & Rede Economize & & & & $12,5 \%$ & $12,5 \%$ & $75,0 \%$ \\
\hline & Total & & $10,0 \%$ & $5,0 \%$ & $5,0 \%$ & $10,0 \%$ & $70,0 \%$ \\
\hline \multirow{3}{*}{$\begin{array}{l}\text { Marca } \\
\text { Própria }\end{array}$} & Rede Econômica & $16,7 \%$ & $58,3 \%$ & $8,3 \%$ & $8,3 \%$ & & $8,3 \%$ \\
\hline & Rede Economize & $12,5 \%$ & $37,5 \%$ & $25,0 \%$ & & $12,5 \%$ & $12,5 \%$ \\
\hline & Total & $15,0 \%$ & $50,0 \%$ & $15,0 \%$ & $5,0 \%$ & $5,0 \%$ & $10,0 \%$ \\
\hline
\end{tabular}

46 Ao não responder, entende-se que a associação não fornece o respectivo item, porém alguns pesquisados assinalaram o Grau de Satisfação número 5 quando o serviço não é prestado, como, por exemplo, Paletização, Propaganda em TV e Acesso à Equipamentos. 
Questão 69. Qual a participação do total dos itens da loja que é fornecido que é fornecido pela associação?

\begin{tabular}{lccc}
\hline $\begin{array}{c}\text { Participação do total dos itens da } \\
\text { loja fornecidos pela associação }\end{array}$ & Rede Econômica & Rede Economize & Total \\
\hline $0-20 \%$ & $25,0 \%$ & $62,5 \%$ & $40,0 \%$ \\
$21-40 \%$ & $16,7 \%$ & $37,5 \%$ & $25,0 \%$ \\
$41-60 \%$ & $58,3 \%$ & & $35,0 \%$ \\
$61-80 \%$ & & & \\
mais de $81 \%$ & & & \\
Não respondeu & & & \\
\hline
\end{tabular}

Questão 70. Qual a diminuição dos custos de aquisição dos custos de aquisição destes produtos (em média)?

\begin{tabular}{lccc}
\hline Redução dos custos de aquisição & Rede Econômica & Rede Economize & Total \\
\hline $0 \%$ & & $12,5 \%$ & $5,0 \%$ \\
$0,1-2 \%$ & $16,7 \%$ & $12,5 \%$ & $15,0 \%$ \\
$2,1-4 \%$ & $58,3 \%$ & $25,0 \%$ & $45,0 \%$ \\
$4,1-6 \%$ & $8,3 \%$ & $12,5 \%$ & $10,0 \%$ \\
mais de 6\% & $16,7 \%$ & $37,5 \%$ & $25,0 \%$ \\
Não respondeu & & & \\
\hline
\end{tabular}

Questão 71. Qual foi o aumento médio no faturamento?

\begin{tabular}{lccc}
\hline Aumento do médio faturamento & Rede Econômica & Rede Economize & Total \\
\hline $0 \%$ & & $12,5 \%$ & $5,0 \%$ \\
$0,1-2 \%$ & & & \\
$2,1-5 \%$ & $8,3 \%$ & $12,5 \%$ & $5,0 \%$ \\
$5,1-10 \%$ & $33,3 \%$ & $75,0 \%$ & $65,0 \%$ \\
mais de 10\% & $58,3 \%$ & & $65,0 \%$ \\
Não respondeu & & & \\
\hline
\end{tabular}

Questão 72. Após início das atividades na associação houve redução no número de funcionários?

\begin{tabular}{lccc}
\hline Redução no número de funcionário & Rede Econômica & Rede Economize & Total \\
\hline Não & $91,7 \%$ & $62,5 \%$ & $80,0 \%$ \\
até 2\% & & & $5,0 \%$ \\
até 6\% & $8,3 \%$ & & \\
até 10\% & & $12,5 \%$ & $5,0 \%$ \\
mais de 10\% & $25,0 \%$ & $10,0 \%$ \\
Não respondeu & & & \\
\hline
\end{tabular}


Questão 73. Após nício das atividades na associação houve redução nos estoques (em volume)?

\begin{tabular}{lccc}
\hline Redução nos estoques & Rede Econômica & Rede Economize & Total \\
\hline Não & $50,0 \%$ & $62,5 \%$ & $55,0 \%$ \\
até 5\% & & & \\
até 10\% & $16,7 \%$ & $12,5 \%$ & $15,0 \%$ \\
até 15\% & $16,7 \%$ & & $10,0 \%$ \\
mais de 15\% & $8,3 \%$ & & $5,0 \%$ \\
Não respondeu & $8,3 \%$ & $25,0 \%$ & $15,0 \%$ \\
\hline
\end{tabular}

Questão 74. Após início das atividades na associação houve redução nos preços dos produtos vendidos?

\begin{tabular}{lccc}
\hline Redução nos preços & Rede Econômica & Rede Economize & Total \\
\hline Não & $8,3 \%$ & $12,5 \%$ & $10,0 \%$ \\
até 2\% & $8,3 \%$ & & $5,0 \%$ \\
até6\% & $66,7 \%$ & $37,5 \%$ & $55,0 \%$ \\
até 10\% & $16,7 \%$ & $12,5 \%$ & $15,0 \%$ \\
mais de 10\% & & & \\
Não respondeu & & $37,5 \%$ & $15,0 \%$ \\
\hline
\end{tabular}

Questão 75. Após início das atividades na associação houve melhora na qualidade dos produtos?

\begin{tabular}{lccc}
\hline Melhora na qualidade dos produtos & Rede Econômica & Rede Economize & Total \\
\hline Não & & $12,5 \%$ & $5,0 \%$ \\
Sim & $66,7 \%$ & $50,0 \%$ & $60,0 \%$ \\
Não sei & $16,7 \%$ & $25,0 \%$ & $20,0 \%$ \\
Não respondeu & $16,7 \%$ & $12,5 \%$ & $15,0 \%$ \\
\hline
\end{tabular}

Questão 76. Após início das atividades na associação houve melhora do atendimento?

\begin{tabular}{lccc}
\hline Melhora no atendimento & Rede Econômica & Rede Economize & Total \\
\hline Não & $91,7 \%$ & $87,5 \%$ & $90,0 \%$ \\
Sim & & & $10,0 \%$ \\
Não sei & $8,3 \%$ & $12,5 \%$ & $10 \%$ \\
Não respondeu &
\end{tabular}

Questão 77. Após início das atividades na associação houve redução nas faltas (produtos ausentes nas lojas)?

\begin{tabular}{lccc}
\hline Redução nas faltas & Rede Econômica & Rede Economize & Total \\
Não & & $12,5 \%$ & $5,0 \%$ \\
Sim & $91,7 \%$ & $62,5 \%$ & $80,0 \%$ \\
Não sei & & $12,5 \%$ & $5,0 \%$ \\
Não respondeu & $8,3 \%$ & $12,5 \%$ & $10,0 \%$ \\
\hline
\end{tabular}


Questão 78. Assinale quais foram as principais razões que levara ao supermercado a associar-se:

\begin{tabular}{lccc}
\hline Principais razões para associar-se & Rede Econômica & Rede Economize & Total \\
\hline Problema com a qualidade dos produtos & $3 \%$ & $5 \%$ & $4 \%$ \\
Falta de Treinamento dos Funcionários & $3 \%$ & $5 \%$ & $4 \%$ \\
Operação da Loja & $6 \%$ & $5 \%$ & $5 \%$ \\
Redução das vendas & $7 \%$ & $5 \%$ & $6 \%$ \\
Acesso às Novas Tecnologias & $7 \%$ & $5 \%$ & $6 \%$ \\
Distanciamento da Indústria & $6 \%$ & $14 \%$ & $9 \%$ \\
Incremento da Profissionalização da Concorrência & $12 \%$ & $9 \%$ & $11 \%$ \\
Altos Custos de Compra das Mercadorias & $12 \%$ & $14 \%$ & $13 \%$ \\
Dificuldade em se Adquirir Mercadorias & $12 \%$ & $14 \%$ & $13 \%$ \\
Aumento da Competição & $15 \%$ & $14 \%$ & $14 \%$ \\
Custos de Propaganda & $16 \%$ & $14 \%$ & $15 \%$ \\
\hline
\end{tabular}

